\title{
ipen
}

AUTARQUIA ASSOCIADA À UNIVERSIDADE DE SÃO PAULO

\section{CLONAGEM DE SERINO PROTEASES DO VENENO DA CASCAVEL Crotalus durissus terrificus E EXPRESSÃO DA GIROXINA EM CÉLULA DE MAMÍFERO}

\section{CAMILA MIYAGUI YONAMINE}

Dissertação apresentada como parte dos requisitos para obtenção do Grau de Mestre em Ciências na Área de Tecnologia Nuclear - Aplicações.

Orientadora:

Dra. Maria Aparecida Pires Camillo

\section{São Paulo}

2007 
INSTITUTO DE PESQUISAS ENERGÉTICAS E NUCLEARES AUTARQUIA ASSOCIADA À UNIVERSIDADE DE SÃO PAULO

\section{CLONAGEM DE SERINO PROTEASES DO VENENO DA CASCAVEL Crotalus durissus terrificus E EXPRESSÃO DA GIROXINA EM CÉLULA DE MAMÍFERO. \\ CAMILA MIYAGUI YONAMINE

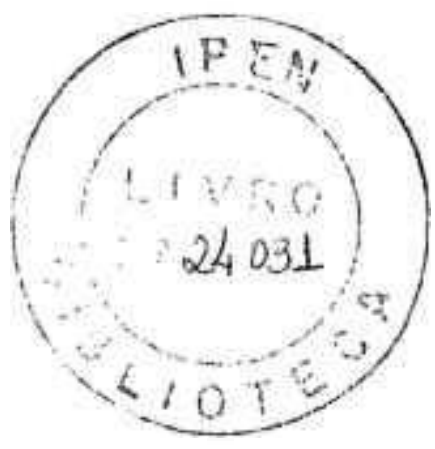 \\ Dissertação apresentada como parte dos requisitos para obtenção do Grau de Mestre em Ciências na Área de Tecnologia Nuclear - Aplicações. \\ Orientadora: \\ Dra. Maria Aparecida Pires Camillo}

SÃO PAULO

2007 
Aos meus pais e às minhas irmãs com amor e carinho 


\section{AGRADECIMENTOS}

À orientadora Dra. Maria Aparecida Camillo, pelos valiosos ensinamentos ministrados e por ter sempre acreditado em mim durante todo o Mestrado.

Ao co-orientador Dr. Álvaro Rossan de Brandão Prieto da Silva, do Instituto Butantan, pela dedicação e incentivo e cujo conhecimento e experiência na área de biologia molecular foram fundamentais para a realização deste projeto.

Ao Prof. Dr.Tetsuo Yamane, pelas orientações sábias e sempre valiosas e por permitir utilizar toda a infra-estrura de seus laboratórios, essencial para a obtenção dos resultados alcançados.

Ao Dr. Gandhi Rádis Baptista, da Universidade Federal de Pernambuco, pelos valiosos ensinamentos nos cursos de Toxinologia molecular, pelas sugestões apresentadas, pelas discussões científicas e por ter cedido gentilmente a biblioteca de CDNA da cascavel Crotalus durissus terrificus.

À Dra Ligia Ely Morganti Ferreira Dias, pelo uso do seu laboratório de cultura celular e pela colaboração na clonagem e expressão da giroxina-símile em célula CHO DXB11 dhfr'.

Ao Dr. Geraldo Santana Magalhães, do Instituto Butantan, pela colaboração nos experimentos de RT-PCR e expressão da giroxinasímile em célula COS-7, e pela paciência que teve durante todo o meu aprendizado no decorrer dos experimentos.

À Dra Regina Affonso pelo apoio dado e pelas discussões científicas realizadas em torno do projeto.

Ao Msc. Ricardo Tsuneo Yassaka, do Instituto de Nanotecnologia do Japão, pela ajuda e incentivo dados no início do projeto.

À Rosa Maria Chura Chambi, pela amizade e pelo auxílio na clonagem da giroxina-símile e na área de cultura celular.

À Juliana Branco Novo, do Instituto Butantan, pela amizade, pelo compartilhamento dos resultados obtidos e pela colaboração científica.

A Flávia Calil Ambiel, pela sua amizade, colaboração e por compartilhar o gosto pela biologia molecular. 
À Dra. Olga Zazuco Higa que, com sua vasta experiência na área de pesquisas, sempre me incentivou a prosseguir com o meu projeto.

À Dra Nanci do Nascimento, gerente do Centro de Biotecnologia, pelo apoio.

Aos amigos, José Alberto Alves da Silva, Janaína Baptista, Danielle Borim, Natália Malavasi, Keli Nunes Balduino, Eduardo de Moura, Larissa Miranda e Vanessa Magalhães, do Centro de Biotecnologia do IPEN, pela amizade e grandes momentos de descontração.

Aos meus pais e às minhas irmãs, pelo grande apoio e incentivo que me deram durante a realização deste projeto de Mestrado.

Ao William Issao Asanuma, pelo amor e compreensão.

À CAPES pela bolsa de Mestrado e ao CNPq pelo auxílio financeiro. 


\title{
Clonagem de serino proteases do veneno da CASCAVEl Crotalus durissus terrificus E EXPRESSÃO DA GIROXINA EM CÉLULAS DE MAMÍFERO.
}

\section{Camila Miyagui Yonamine}

\begin{abstract}
Resumo
As serino proteases participam de diversos processos fisiológicos (tal como o de coagulação) e patológicos. Essas enzimas estão amplamente distribuídas entre as espécies, são também toxinas dos venenos de serpentes. sendo denominadas SVSPs (snake venom serine proteases). Essas SVSPS são multifuncionais e contêm uma tríade catalítica formada pelos aminoácidos HDS. Algumas SVSPS são comercialmente disponíveis, sendo indicadas para o tratamento de infarto do miocárdio, tromboses e embolia pulmonar. No veneno de Crotalus durissus terrificus estão descritas até o momento, apenas duas SVSPs sendo que a mais estudada é a giroxina que representa cerca de $2,5 \%$ do veneno total. No presente estudo foi reportado a clonagem de sete serino proteases amplificadas a partir de uma biblioteca de CDNA de glândula de veneno de um único espécime adulto de Crotalus durissus terrificus. Estes clones foram analisados com relação à organização do cDNA, estrutura e prováveis funções. A construção do modelo tridimensional da giroxina permitiu verificar as similaridades com tripsina, trombina e outras SVSPs.

A glicosilação e a presença de muitas pontes dissulfetos dificultam a obtenção das SVSP recombinantes na forma solúvel e com atividade, por expressão em E.coli. Assim, neste trabalho foi abordada a expressão em células de mamífero (que realiza as modificações pós-traducionais) com resultados promissores. Para tanto, o peptídeo sinal de Igk, a seqüência madura e a região $3^{\prime}$ UTR da giroxina foram clonados no vetor $P E D$, originando um novo vetor ( $p E D$-Giro). Este vetor carrega o peptídeo sinal de Igk, o que possibilitou a secreção da giroxina para o meio de cultura. $O$ vetor pED-Giro foi transfectado em células CHO DXB11 dhfr e cOS-7. A giroxina foi detectada no extrato total das células COS-7 por western blot e, em seguida, purificada do meio de cultura com coluna de afinidade (Benzamidina Sepharose) e demonstrado sua integridade pelo ensaio de atividade esterásica.
\end{abstract}


CLONING OF SERINE PROTEASES FROM THE VENOM OF RATTLESNAKE Crotalus durissus terrificus AND EXPRESSION OF A GYROXIN IN MAMMALIAN CELLS.

\title{
Camila Miyagui Yonamine
}

\begin{abstract}
The serine proteases affect several physiological processes (such as the coagulation cascade) and pathological ones. These enzymes are widely distributed beyond the species; they are also toxins from snake venoms and are called SVSPs (snake venom serine proteases). These SVSPs are multifunctional and have a catalytic triad formed by HDS amino acids. Some of them are commercially available for use in clinical treatment for heart attack, tromboses and pulmonary embolism. So far, in Crotalus durissus terrificus venom only two SVSPS are described and gyroxin is considered the most studied SVSP which represents about 2,5\% of the total venom. In the present study was reported the cloning of seven serine proteases amplified from a cDNA library of a venomous gland of a single adult specimen from Crotalus durissus terrificus venom. These clones have been analyzed in relation to the cDNA organization, structure and probable functions. The three-dimensional model of the gyroxin made possible the analysis of similarities with trypsin, thrombin and other SVSPS.

The glycosylation and many disulfide bonds of the SVSPs make difficult the expression in E.coli to obtain the soluble recombinant toxin with activity. The expression in mammalian cells is very promising, because it is possible to make pos translation modification and to obtain the recombinant toxin secreted to the culture medium. The IgK signal peptide, the mature sequence and 3'UTR region of gyroxin were cloned in the $\mathrm{PED}$ expression vector resulting in a new vector ( $\mathrm{pED}$-Giro). This vector carries the Igk signal peptide, which allows the secretion of the protein to the culture medium. The pED-Giro vector was transfected in CHO DXB11 dhfr' and COS-7 cells. The gyroxin was detected in COS-7 total extract by western blot and after, purified from the medium culture and its integrity was confirmed by esterase activity assay.
\end{abstract}




\section{SUMÁRIO}

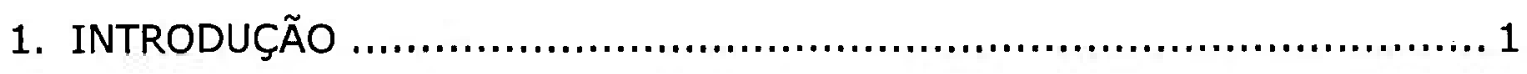

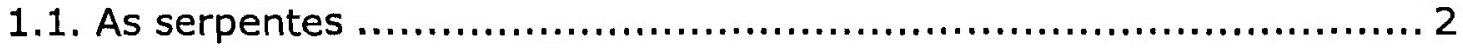

1.1.1. As cascavéis e o veneno ................................................ 3

1.2. Serino proteases ........................................................ 3

1.2.1. Subfamília S1A .................................................. 4

1.2.2. Serino proteases no veneno da cascavel Crotalus durissus terrificus

5

1.2.2.1. Trombina-símile .......................................... 5

1.2.2.2. Giroxina ................................................ 5

1.3. Serino proteases recombinantes dos venenos de serpentes ...........8 8

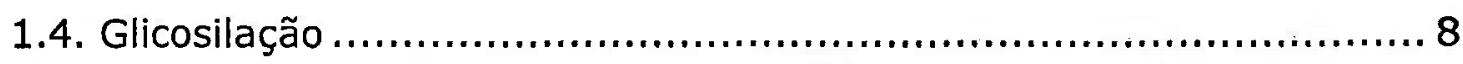

1.5.Sistemas de expressão de proteína recombinante ....................... 10

1.5.1. Sistemas de expressão em Escherichia coli ........................ 10

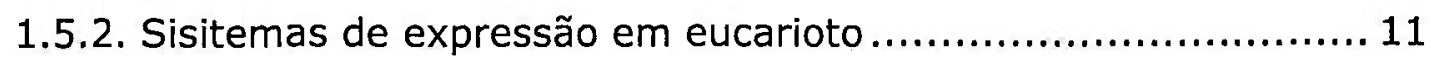

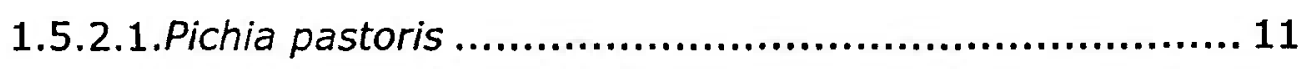

1.5.2.2. Célula de mamifero .................................. 11

1.6- Aplicações das serino proteases do veneno de serpente em saúde ... 12

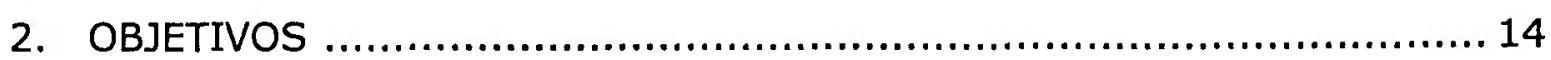

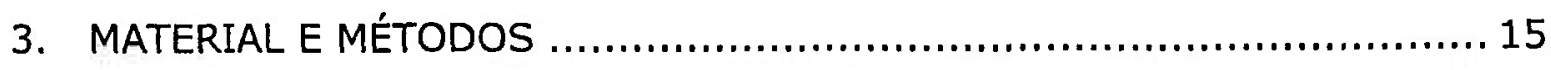

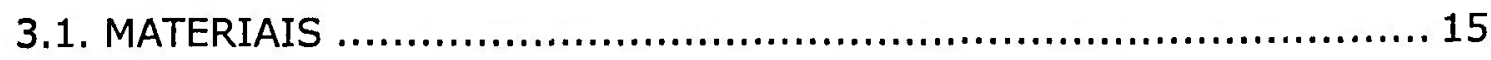

3.1.1. Materiais utilizados nos ensaios de Biologia Molecular, Cultura de Células e Análises de Proteínas..................................... 15

3.1.2. Equipamentos .................................................. 17

3.1.3. Ferramentas de Bioinformática ................................... 18

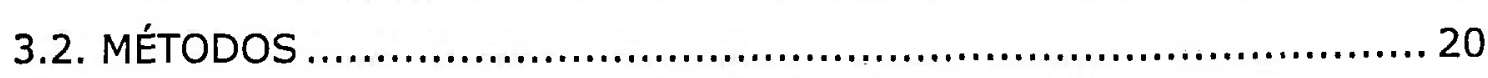

3.2. - Obtenção do clone PCR2.1 TOPO-B2.1 .............................. 20

3.2.1. Definição do primer GYR SE ..................................... 20

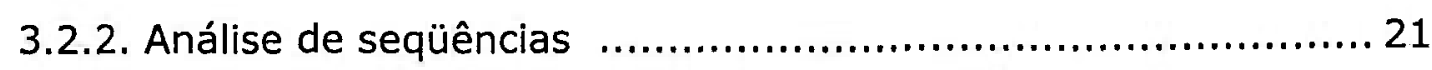




\section{SUMÁRIO}

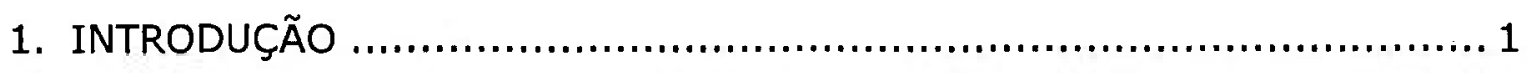

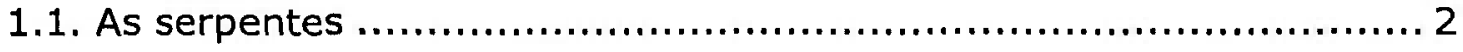

1.1.1. As cascavéis e o veneno ................................................ 3

1.2. Serino proteases ........................................................ 3

1.2.1. Subfamília S1A .................................................. 4

1.2.2. Serino proteases no veneno da cascavel Crotalus durissus terrificus

5

1.2.2.1. Trombina-símile .......................................... 5

1.2.2.2. Giroxina ................................................ 5

1.3. Serino proteases recombinantes dos venenos de serpentes ...........8 8

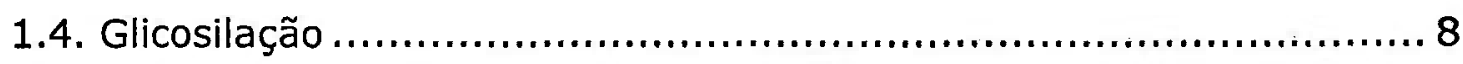

1.5.Sistemas de expressão de proteína recombinante ....................... 10

1.5.1. Sistemas de expressão em Escherichia coli ........................ 10

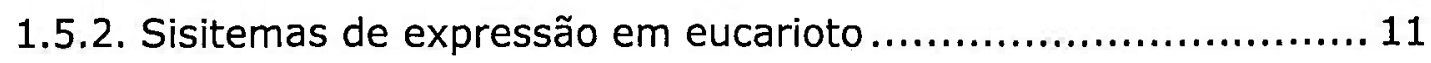

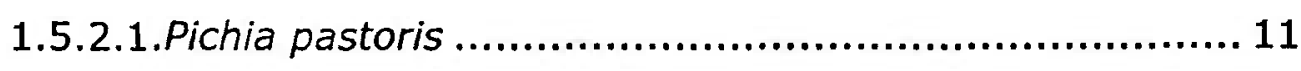

1.5.2.2. Célula de mamifero .................................. 11

1.6- Aplicações das serino proteases do veneno de serpente em saúde ... 12

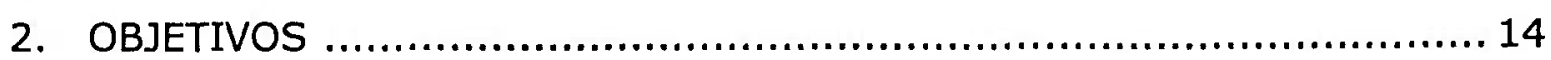

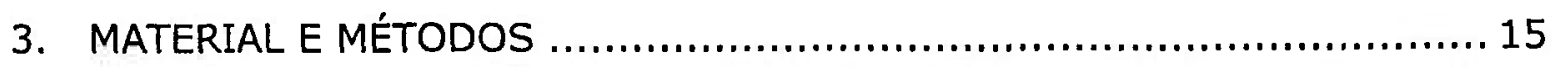

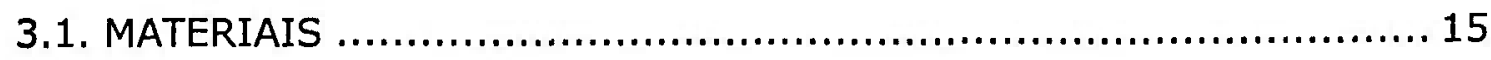

3.1.1. Materiais utilizados nos ensaios de Biologia Molecular, Cultura de Células e Análises de Proteínas..................................... 15

3.1.2. Equipamentos .................................................. 17

3.1.3. Ferramentas de Bioinformática ................................... 18

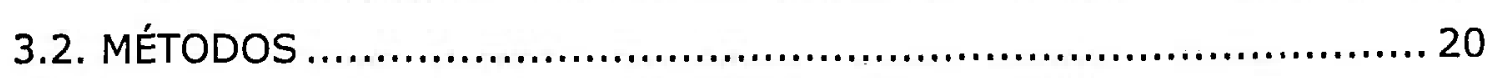

3.2. - Obtenção do clone PCR2.1 TOPO-B2.1 .............................. 20

3.2.1. Definição do primer GYR SE ..................................... 20

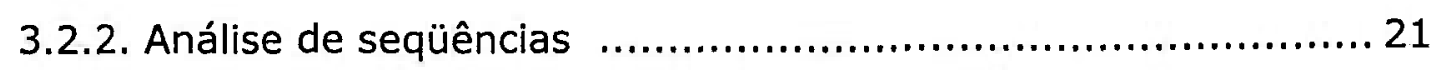


3.3. Clonagem de isoformas de serino proteases similares a giroxina ..... 22

3.3.1. Obtenção dos clones pCR2.1 TOPO-GPSs........................ 22

3.3.2. Obtenção dos clones pCR2.1 TOPO-PST7s........................ 23

3.4. Análise das seqüências de cDNA e de proteínas dos clones obtidos... 24

3.4.1. Alinhamento e Dendrograma ...................................... 24

3.4.2. Análise dos precursores ........................................ 24

3.4.3. Análise das toxinas maduras ................................... 25

3.5. Comparação das toxinas maduras dos clones obtidos com outras

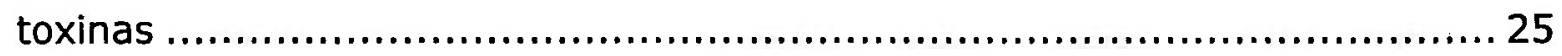

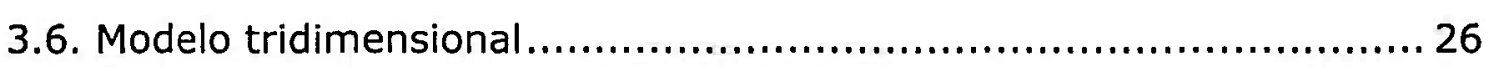

3.7. Construção do vetor de expressão pED-Giro ........................... 27

3.7.1. Obtenção do inserto da giroxina madura......................... 27

3.7.2. Preparo do vetor pSecTag2 Hygro A .............................. 28

3.7.3. Ligação do inserto giroxina-símile em pSecTag2Hygro $A$ e seleção do clone pSecTag2-Giro.............................................. 28

3.7.4. Mutagênese sítio dirigida ...................................... 29

3.7.4.1. Preparo de DNA de fita simples......................... 29

3.7.4.2. Fosforilação do primer .................................. 30

3.7.4.3. Reação de mutagênese.................................... 30

3.7.5. Seleção do clone mutante pSecTag2-Igk-Giro ...................... 31

3.7.6. Obtenção do inserto IgK-Giro .................................. 32

3.7.7. Preparo do vetor pED para subclonagem do inserto IgK Giro .... 32

3.7.8. Ligação do inserto IgK-Giro no vetor pED e seleção do clone

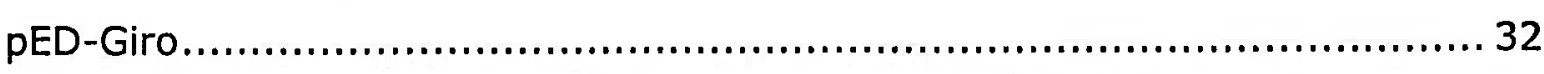

3.8. Expressão do vetor pED-Giro em células CHO DXB11 dhfr ${ }^{-} \ldots \ldots \ldots . . . . .33$

3.8.1. Seleção e amplificação dos clones.................................. 33

3.8.2. Detecção da proteína recombinante expressa pelo vetor pEDGiro em células CHO DXB11 por SDS-PAGE e western blot..................... 34

3.8.3- Detecção do vetor integrado ao genoma da célula $\mathrm{CHO}$

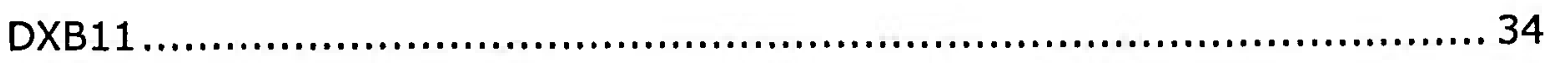

3.8.4- Detecção do mRNA expresso pela célula CHO-DXB11x pEDGiro......................................................................... 35

3.9. Expressão transiente do vetor pED-Giro em células COS-7 ............. 36 
3.9.1. Purificação do produto recombinante expresso pelo vetor pED Giro em células COS-7

3.9.1.1. Dosagem de proteína recombinante expressa pelo vetor pED-Giro em células cos-7.

3.9.1.2- Detecção da proteína recombinante expressa pelo vetor pED-Giro em células COS-7 por SDS-PAGE e western blot

3.9.2. Ensaio de atividade enzimática da giroxina recombinante purificada por benzamidina sepharose ............................................ 39

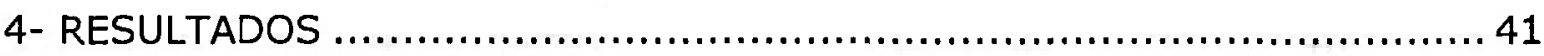

4.1. Clonagem da toxina madura........................................... 41

4.1.1. Análises dos clones correspondentes às bandas B0, B1 e B2 ... 41

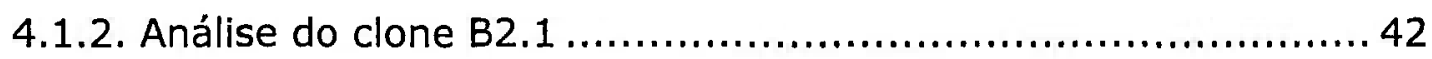

4.2. Clonagem de isoformas de serino proteases similares a giroxina ...... 43

4.2.1. Obtenção dos clones pCR2.1 TOPO-GPSs........................... 43

4.2.1.1. Análises das seqüências de CDNA e de proteína dos

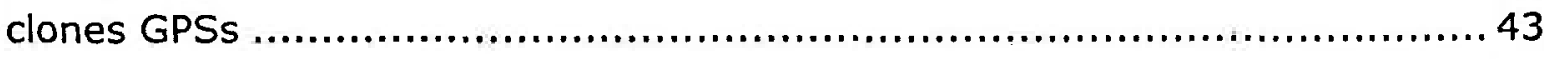

4.2.1.2- Análise do clone GPS:2e5 ................................. 44

4.2.1.3-Análise do clone GPS:3e4 ................................. 45

4.2.2. Obtenção dos clones PCR2.1 TOPO-PST7s.......................... 46

4.2.2.1. Análises das seqüências de cDNA e de proteínas dos

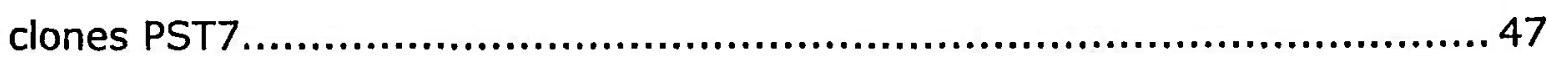

4.2.2.2. Análise do clone PST7:3 ................................. 47

4.2.2.3. Análise do clone PST7:4..................................... 48

4.2.2.4. Análise do clone PST7:7e8 ................................. 48

4.2.2.5. Análise do clone PST7:5.................................. 49

4.2.3. Comparação dos CDNA dos clones B2.1, GPSs e PST7s com os éxons do gene de Batroxobin ................................................... 50

4.3. Análise das seqüências de CDNA e de proteínas dos clones obtidos... 51

4.3.1. Alinhamento e Dendrograma ......................................... 51

4.3.2. Análise do peptideo sinal dos precursores ......................... 52

4.3.3. Análise das toxinas maduras .......................................... 53

4.4. Comparação das toxinas maduras dos clones obtidos com outras toxinas 


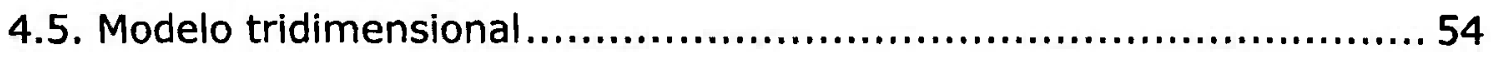

4.6. Construção do vetor de expressão pED-Giro ............................... 55

4.6.1. Obtenção do inserto da giroxina madura........................... 55

4.6.2. Preparo do vetor pSecTag2 Hygro A ................................... 55

4.6.3. Seleção do clone pSecTag2-Giro ..................................... 55

4.6.4. Seleção do clone mutante pSecTag2 Igk-Giro...................... 56

4.6.5. Obtenção do inserto IgK-Giro ..................................... 57

4.6.6. Preparo do vetor PED para subclonagem do inserto IgK-Giro.... 57

4.6.7. Seleção do clone pED-Giro ..............................................5 57

4.7. Expressão do vetor PED-Giro em células CHO DXB11 dhfr ${ }^{-}$.............58

4.7.1. Seleção e amplificação dos clones...................................... 58

4.7.2. Detecção da proteína recombinante expressa pelo vetor $\mathrm{PED}$ -

Giro em células CHO DXB11 por SDS-PAGE e western blot. 58

4.7.3. Detecção do vetor integrado ao genoma da célula $\mathrm{CHO}$

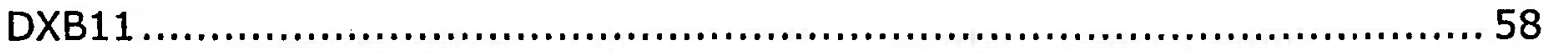

4.7.4. Detecção do mRNA expresso pela célula CHO-DXB11x pED-

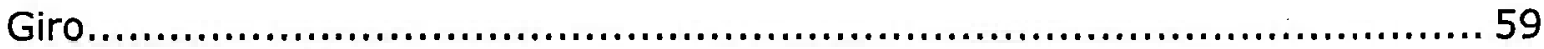

4.8. Expressão transiente do vetor pED-Giro em células COS-7 .............62 62

4.8.1. Purificação do produto recombinante expresso pelo vetor pED-Giro em células COS-7

4.8.1.1 Deteç̧ão da proteina recombinante expressa pelo vetor PED-Giro em células COS-7 por SDS-PAGE e western blot 62

4.9.Ensaio de atividade enzimática da giroxina recombinante purificada por benzamidina sepharose ........................................................... 64

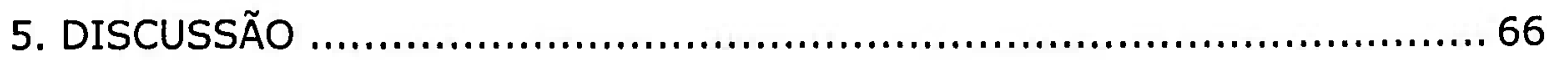

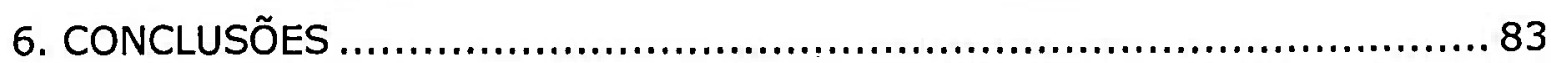

7. FIGURAS

Figura 1. Filogenia sugerida para a subfamília Crotalinae ..................8 84

Figura 2. Cascavel apresentando o chocalho (guizo) e a distribuição geográfica Crotalus durissus terrificus............................................. 84

Figura 3. Sítio ativo de uma serino protease ................................. 85

Figura 4. Estrutura tridimensional da tripsina................................ 85 
Figura 5. Algumas serino proteases do veneno de serpentes agindo na cascata de coagulação............................................................. 86

Figura 6. Seqüências do $\mathrm{N}$-terminal da giroxina de C.d.terrificus ....... 87

Figura 7. Pontos de clivagem da molécula do fibrinogênio .................8 88

Figura 8. Definição do primer GYR SE .................................... 89

Figura 9. Esquema do PCR para obter o clone B2.1. ...................... 90

Figura 10. Esquema do PCR para obter os clones GPSs .................. 90

Figura 11. Esquema do PCR para obter os clones PST7s................... 90

Figura 12. Esquema da construção do vetor de expressão da giroxina em células CHO-DXB11 dhfr' e COS-7 .................................... 91

Figura 13. Detecção do vetor pED-Giro integrado ao genoma da célula CHO-DXB11. ............................................................. 92

Figura 14. Detecção do mRNA expresso pela célula CHO-DXB11X pED-Giro............................................................................ 93

Figura 15. Amplificação da biblioteca de CDNA da glândula de veneno da cascavel Crotalus durissus terrificus por PCR .......................... 94

Figura 16. Seleção do clone B2.1 por PCR .................................. 94

Figura 17. Comparação dos 30 primeiros aminoácidos do clone de giroxina B2.1 com as seqüências $\mathrm{N}$-terminais da giroxina isolada do veneno de Crotalus durissus terrificus .......................................... 95

Figura 18. Organização do cDNA do clone B2.1 (895pb)................. 96

Figura 19. Organização do cDNA do clone GPS2 e 5 (998pb) ............. 97

Figura 20. Organização do cDNA do clone GPS3 e 4 (973pb) ............ 98

Figura 21. Região de hibridação do primer para o peptídeo sinal ........ 99

Figura 22. Obtenção dos clones pCR2.1 TOPO-PST7s.................... 100

Figura 23. Organização do cDNA do clone PST7:3 (1429pb) ............ 101

Figura 24. Organização do cDNA do clone PST7:4 (1420pb) ............ 102

Figura 25. Organização do cDNA do clone PST7:7e8 (1407pb) ......... 103

Figura 26. Organização do cDNA do clone PST7:5 (1272pb) ........... 104

Figura 27. Análise da organização dos cDNAs. ............................ 105

Figura 28. Dendrograma das seqüências de nucleotídeos dos clones de CDNA B2.1, GPS:2e5, GPS:3e4, PST7:3, PST7:4, PST7:5 e PST7:7e8 ... 106 
Figura 29. Alinhamento em nucleotídeos e aminoácidos dos clones B2.1, GPS: 2e5, PST7:3, PST7:7e8, GPS: 3e 4, PST7:4 e PST7:5 ............ 107

Figura 30. Análise do precursor.............................................. 108

Figura 31. Predição de clivagem do peptídeo sinal do clone PST7:3 .. 109

Figura 32. Dendrograma das seqüências de aminoácidos correspondentes às toxinas maduras codificadas pelos clones: B2.1, GPS:2e5, GPS:3e4, PST7:3, PST7:4 e PST7:7e8.

Figura 33. Dendrograma funcional de serino proteases do veneno de serpentes

Figura 34. Alinhamento de serino proteases do veneno de serpente . 112

Figura 35. Modelo tridimensional da giroxina

Figura 36. Comparação do modelo da giroxina com o modelo cristalográfico da tripsina bovina (2ptc).

Figura 37. Comparação dos modelos tridimensionais da giroxina e crotalase com o modelo cristalográfico da cadeia pesada da a- trombina

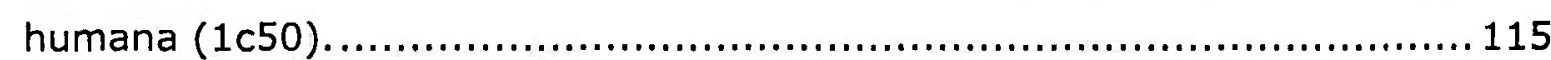

Figura 38. Esquema do vetor PCR2.1-Giro (clone B2.1) ................ 116

Figura 39. Esquema do vetor pSecTag2-Giro antes da mutagênese .. 117

Figura 40. Seleção do clone pSecTag2-Giro ............................... 118

Figura 41. Análise por PCR do clone pSecTag2-Giro recombinante.... 118

Figura 42. Seleção por PCR dos clones pSecTag2-IgK-Giro obtidos após a mutagênese sítio dirigida.

Figura 43. Análise de restrição dos clones mutantes pSecTag2-IgKGiro

Figura 44. Esquema do vetor pSecTag2-IgKGiro após a mutagênese 120

Figura 45. Seleção por tamanho dos clones recombinantes pEDGiro

Figura 46. Análise por PCR do clone pED-Giro recombinante..... 121

Figura 47. Esquema do vetor pED-Giro 122

Figura 48. Uma colônia de células CHO-DXB11 transfectada com o vetor pED-Giro 
Figura 49. Detecção do vetor pED-Giro integrado no genoma da

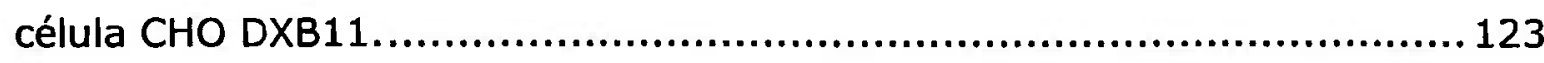

Figura 50. RNA total isolado das amostras célula CHO-K1 dhfr', clones 4 e 8 (CHO-DXB11 x pED-Giro) na presença e ausência de MTX......124

Figura 51. Detecção do mRNA expresso pelos clones 4 e 8 ( $\mathrm{CHO}$ DXB11 x pED-Giro) por RT-PCR.

Figura 52. RNA total isolado das amostras clone 4 e 6 na presença e ausência de MTX e célula CHO-DXB11 dhfr'.

Figura 53. Detecção do mRNA expresso pelos clones 4 e 6 na ausência e presença de MTX por RT-PCR.

Figura 54. Transfecção da célula COS-7x pED-Giro 126

Figura 55. Detecção da proteína recombinante expresso pelo vetor pED-Giro em células COS-7.

Figura 56. Detecção da proteína recombinante expressa pelo vetor pED-Giro em células COS-7 e purificada pela resina de afinidade benzamidina sepharose

Figura 57. Ensaio de atividade enzimática da giroxina recombinante expresso em COS-7 após a purificação por afinidade em resina benzamidina sepharose.

\section{TABELAS}

Tabela 1. Descrição dos vetores 130

Tabela 2. Descrição dos primers utilizados para clonagem e sequenciamento, mutagênese e RT-PCR 131

Tabela 3. Descrição dos primers universais .............................. 132

Tabela 4. Enzimas utilizadas na manipulação do DNA ou RNA ........... 133

Tabela 5. Descrição das bactérias eletrocompetentes e quimicamente competentes utilizadas. 134

Tabela 6. Análise dos clones pelo software Phred ........................ 135

Tabela 7. Análise de homologia do cDNA do clone B2.1 comparando-se com seqüências do banco de dados do NCBI ....................136

Tabela 8. Análise de homologia da proteína codificada pelo clone B2.1 comparando-se com seqüências do banco de dados do NCBI. 
Tabela 9. Análise de homologia do CDNA do clone GSP:2e5 comparando-se com seqüências do banco de dados do NCBI

Tabela 10. Análise de homologia da proteína codificada pelo clone GPS:2e5 comparando-se com seqüências do banco de dados do NCBI.......137

Tabela 11. Análise de homologia do cDNA do clone GSP:3e4 comparando-se com seqüências do banco de dados do NCBI

Tabela 12. Análise de homologia da proteína codificada pelo clone GPS:3e4 comparando-se com seqüências do banco de dados do NCBI....... 138

Tabela 13. Análise de homologia do CDNA do clone PST7:3 comparando-se com seqüências do banco de dados do NCBI

Tabela 14. Análise de homologia da proteína codificada pelo clone PST7:3 comparando-se com seqüências do banco de dados do NCBI

Tabela 15. Análise de homologia do CDNA do clone PST7:4 comparando-se com seqüências do banco de dados do NCBI

Tabela 16. Análise de homologia da proteína codificada pelo clone PST7:4 comparando-se com seqüências do banco de dados do NCBI

Tabela 17. Análise de homologia do cDNA do clone PST7:7e8 comparando-se com seqüências do banco de dados do NCBI

Tabela 18. Análise de homologia da proteína codificada pelo clone PST7:7e8 comparando-se com seqüências do banco de dados do NCBI ..... 141

Tabela 19. Análise de homologia do CDNA do clone PST7:5 comparando-se com seqüências do banco de dados do NCBI.

Tabela 20. Análise de homologia da proteína codificada pelo clone PST7:5 comparando-se com seqüências do banco de dados do NCBI

Tabela 21. Análise da organização dos cDNAs Giroxina símile em relação ao gene de Batroxobin....

Tabela 22. Similaridades em porcentagem entre as seqüências de cDNA dos clones de B2.1, GPS:2e5, GPS:3e4, PST7:3, PST7:4, PST7:5 e PST7:7e8

Tabela 23. Similaridade em porcentagem das toxinas maduras dos clones B2.1, GPS:2e5, GPS:3e4, PST7:3, PST7:4, PST7:7e8 
Tabela 24. Seqüências homólogas com mais alto escore de similaridade em relação à toxina madura codificada pelos clones B2.1, GPS:2e5, GPS:3e4,PST7:3, PST7:4, PST7:7e8

Tabela 25. Concentração do RNA total isolado das amostras dos clones de célula CHO-DXB11 x pED-Giro na presença ou ausência de MTX para RT-PCR e da célula controle negativo CHO-DXB11 dhfr

Tabela 26. Quantificação de proteína e atividade específica da proteína recombinante antes e após a purificação por resina de afinidade

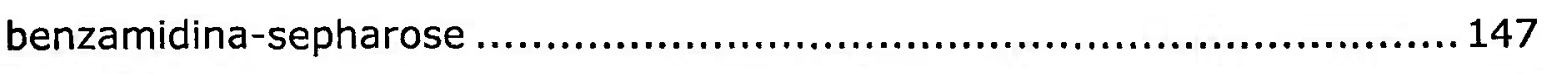

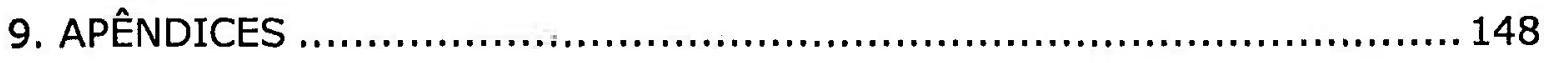

9.1. Protocolos de Biologia Molecular .................................. 148

9.1.1- Eletroforese em gel de agarose .............................. 148

9.1.2-Reação de ligação................................................... 148

9.1.2.1-Topoisomerase (pCR2.1TOPO) ....................... 148

9.1.2.2- T4 DNA ligase ...................................... 148

9.1.3- Métodos de transformação...................................... 149

9.1.3.1-Bactérias competentes ................................... 149

9.1.3.2-Método de tranformação por eletroporação .............. 149

9.1.3.3-Método de transformação por choque térmico ........... 149

9.1.4- Isolamento de colônias transformantes .......................... 149

9.1.5- Reação em Cadeia da Polimerase (PCR) para clonagens ........ 149

9.1.6- Purificação por fenol/clorofórmio e precipitação do DNA ........ 150

9.1.7- Seleção dos clones recombinantes .............................. 150

9.1.7.1- por $\alpha$-complementação................................. 150

9.1.7.2-Por tamanho do plasmídeo recombinante................ 150

9.1.7.3-Por PCR de colônias .................................... 151

9.1.7.4-Por mapa de restrição ................................... 151

9.1.8- Preparação de DNA plasmidial e purificação do DNA em gel

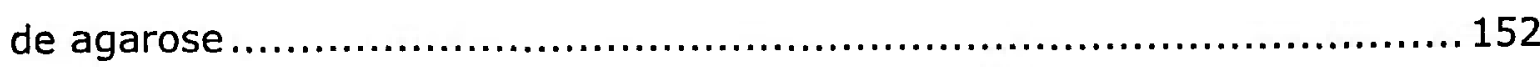

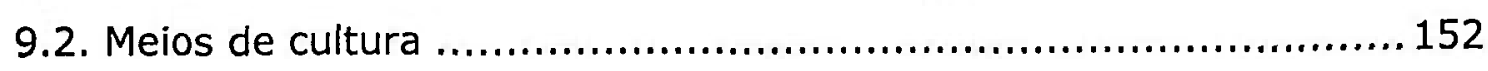

9.2 .1 -Meio líquido .................................................. 152

9.2.1.1 - LB (Meio Luria Bertani) ............................. 152

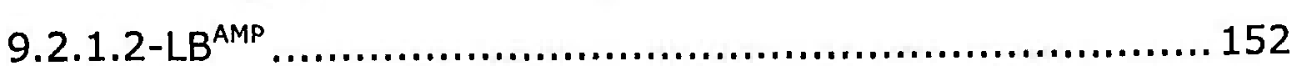




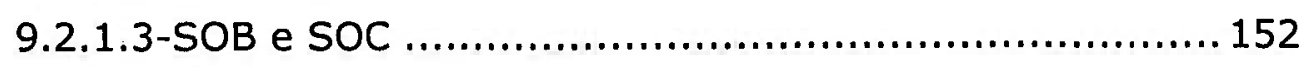

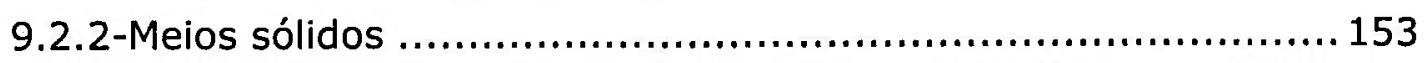

9.2.2.1- LB-ágar .................................................... 153

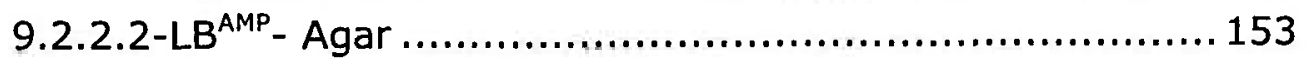

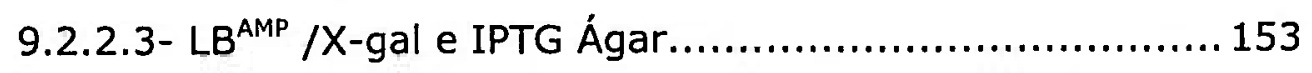

9.2.2.4-Meio YT ........................................................ 153

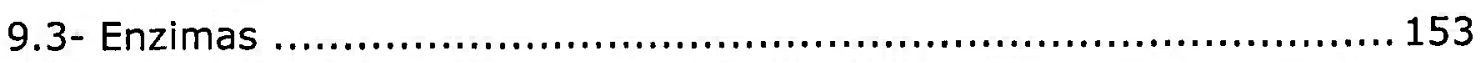

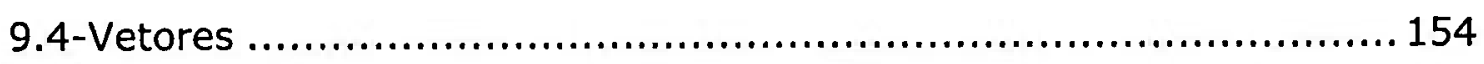

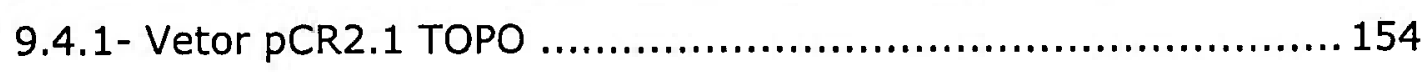

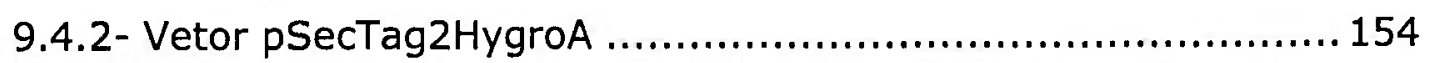

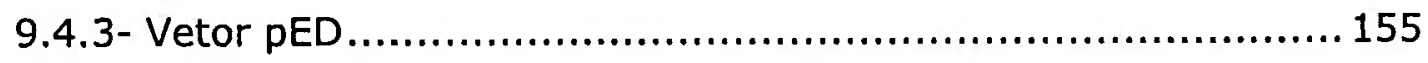

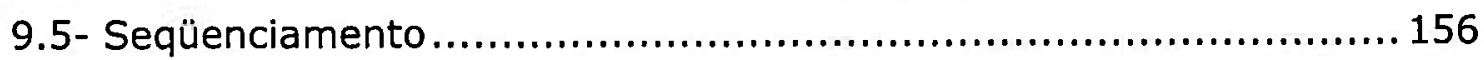

9.6- Análise de proteína .................................................... 158

9.6.1 - Eletroforese em gel de poliacrilamida com SDS................. 158

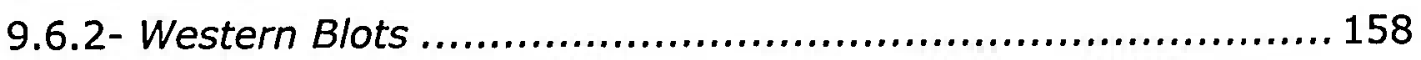

10. REFERÊNCIAS BIBLIOGRÁFICAS ........................................ 160 


\section{INTRODUÇÃo}

Os venenos de serpentes apresentam diversas toxinas com atividade de enzimas proteolíticas que afetam diversos processos fisiológicos, entre eles o processo de coagulação. Até hoje somente 40 enzimas trombina-símile foram isoladas e caracterizadas. No entanto o seqüenciamento diretamente da proteína é um método trabalhoso e demorado o que talvez justifique o reduzido número (CASTRO et al, 2004). Essas toxinas são pouco caracterizadas bioquimicamente, podendo existir isoformas no veneno de serpentes que ainda são desconhecidas.

Nos últimos 5 anos, devido ao avanço na área de biologia molecular este quadro está mudando, pois a clonagem molecular permite conhecer como ocorre o processamento do gene, qual é a seqüência da região não traduzida 5 'UTR, a região codificante para o peptídeo sinal, para o pré-peptídeo, para a toxina madura e a região não traduzida 3 'UTR. Uma vez obtida a seqüência de cDNA é possível predizer a seqüência primária da toxina e verificar a existência de isoformas.

As toxinas dos venenos de serpentes apresentam diversas pontes dissulfetos, aumentando sua estabilidade e tolerância às mudanças de $\mathrm{pH}$ fisiológico e temperatura que acontecem entre o lúmem da glândula da serpente e a distribuição nos tecidos da presa. Muitas das toxinas, incluindo as com atividade enzimática, além das pontes dissulfetos, apresentam $\mathrm{N}$ glicosilações. Estas duas características associadas à citotoxicidade de muitas toxinas podem justificar as dificuldades de obtê-las na forma recombinante.

Muitas tentativas relativas à expressão de toxinas animais em bactéria, freqüentemente em E.coli, foram publicadas (MAEDA et al.1991; HAHN et al.1996; PAN et al.,1999; HUNG \& CHIOU,2000; GUO et al.,2001: ZHA et al.2003; YANG et al.,2003, YUAN et al.,2004) principalmente com os objetivos de caracterização e melhor conhecimento da função, no entanto neste sistema de expressão procariótico não ocorrem as modificações pós-traducionais e a maioria das proteínas recombinantes são obtidas em corpos de inclusão, sem atividade biológica frustando o objetivo inicial. Assim novos métodos de refolding in vitro têm sido desenvolvidos na tentativa de solucionar esse problema, mas nos resultados ainda há muita variabilidade na eficiência no processo de renaturação da proteína, com baixo rendimento e, em alguns 
casos, a toxina expressa renaturada apresenta atividade biológica diminuída (HUNG \& CHIOU 2000; YUAN et al, 2004).

Neste contexto, este trabalho visa contribuir desenvolvendo a expressão de uma toxina de serpente em um sistema eucariótico - em célula de mamífero. Este sistema de expressão eucarioto é capaz de formar pontes dissulfetos e modificações pós-traducionais como a glicosilação, permitindo a obtenção e a secreção de uma proteína recombinante em sua forma ativa de forma similar à glândula de veneno. Para tanto, foi escolhida a giroxina - uma proteína do veneno da cascavel brasileira Crotalus durissus terrificus com atividades neurotóxica e trombina símile, porém com baixa citotoxicidade.

\section{1-As serpentes.}

As serpentes estão distribuídas pelo mundo e habitam o solo, as árvores ou a água. Elas são classificadas em 14 ou 15 famílias com 2.400 espécies. As serpentes da família Viperidae apresentam duas subfamílias principais: Viperinae e Crotalinae.

Os membros da subfamília Viperinae são encontrados na Europa, Ásia e África, menos em Madagascar. Esta subfamília apresenta nove gêneros e aproximadamente 54 espécies, sendo que o gênero Vipera contém 22 espécies sendo amplamente distribuídas desde o norte da Escandinávia, até o leste do Japão e na região sul de Taiwan.

Já a subfamília Crotalinae (pit vipers) ocorre na Ásia (Calloselasma rhodostoma - sudeste asiático, Deinagkistrodon - Ásia, Gloydius - Ásia e Japão, Trimeresurus - Ásia, Agkistrodon - América do Norte e América Central, Crotalus - América do Norte até o América do Sul, Sistrurus América do Norte, América Central, Lachesis- América Central e América do Sul, Bothrops- América do Sul. Esta subfamília é mais especializada que a Viperinae por apresentar a fosseta loreal, órgão sensorial capaz de perceber variações de temperatura de até $0,01^{\circ} \mathrm{C}$, localizado em uma cavidade entre o olho e a narina. Todas as serpentes dessa subfamília são potencialmente perigosas ao homem (BRATTSTROM, 1964; MATTISON, 1995, GUTBERLET JR, R. L. \& CAMPBELL, J. A, 2001).

$\mathrm{Na}$ figura 1 podemos observar uma filogenia que traça a relação das serpentes dos gêneros Trimeresurus, Bothrops, Agkistrodon, Lachesis com as serpentes do gênero Crotalus. As serpentes pertencentes ao gênero 
Agkistrodon e Trimeresurus são as mais primitivas dessa subfamília Crotalinae. (BRATTSTROM, 1964). É possivel encontrar toxinas similares em Lachesis e Crotalus, como o análogo de trombina-símile/giroxina encontrada nas serpentes Lachesis muta muta e Crotalus durissus terrificus (MAGALHÃES et al, 1993, CAMILLO et al, 2001).

\subsection{1- As cascavéis e o veneno.}

As cascavéis pertencem à família Viperidae subfamília Crotalinae e gênero Crotalus. Este gênero possui 26 espécies encontradas desde o norte do Canadá até o sul da Argentina e apresenta como principal característica o guizo ou chocalho (Do grego: krotalon).

A subespécie Crotalus durissus terrificus pode ser encontrada em regiões normalmente semi-áridas e secas do território brasileiro até países vizinhos onde a sua picada é muito temida (AMARAL,1978) (figura 2). Em seu veneno existem 4 grupos de toxinas majoritárias:

- Fosfolipases $A_{2}$ (crotoxina, principal neurotoxina do veneno descrita por SLOTTA \& FRAENKEL-CONRAT, 1938).

- Metaloproteases (convulxina descrita por PRADO-FRANCESCHI \& VITAL BRAZIL, 1981.).

- Miotoxinas (crotamina descrita por GONÇALVES \& VIEIRA, 1950).

- Serinoproteases (giroxina descrita por BARRIO, 1961 e uma trombina-simile descrita por RAW et al,1986). Estas toxinas estão apenas parcialmente caracterizadas sendo que a giroxina está envolvida em efeitos neurotóxico e coagulante.

\section{2- Serino proteases.}

As serino proteases são enzimas proteolíticas que utilizam serina no seu sítio catalítico, são muito freqüentes e formam a maior superfamília das peptidases, sendo encontradas desde vírus e bactérias, até em eucarióticos (RAWLINGS \& BARRETT, 1993).

As serino proteases possuem uma ampla gama de atividades incluindo exopeptidases, endopeptidases, oligopeptidases e omega-peptidases. Mais de 20 famílias (denominadas de $\mathrm{S1}$ a S66) de serino proteases foram identificadas até o momento e são agrupadas segundo sua similaridade estrutural e evidências funcionais (RAWLINGS \& BARRETT 1994). 
As famílias das serino proteases podem ter diferentes origens evolutivas e, portanto, diferentes estruturas tridimensionais. Entretanto, a reação proteolítica compartilha uma similaridade no mecanismo sendo que a quimotripsina, a subtlisina e a carboxipeptidase $\mathrm{C}$ tem em comum uma tríade catalítica formada por serina, ácido aspártico e histidina. A serina age como nucleófilo, o aspartato como eletrófilo e a histidina como base (figura 3 ).

\subsection{1- Subfamília S1A.}

As serino proteases da subfamília S1A apresentam como principal característica um domínio tripsina.

A subfamília S1A (família da quimotripsina bovina) é a maior de todas as famílias de proteases, com mais de 4875 seqüências de enzimas identificadas até ao momento. Apresentam a tríade catalítica His-Asp-Ser e as seqüências de aminoácidos ao redor do sítio catalítico formam motivos muito conservados. Suas estruturas tridimensionais são extremamente conservadas. Até o momento todas as proteases da família S1 são endopeptidases.

Diversas serino proteases da família da quimotripsina já tiveram sua estrutura tridimensional determinada. A quimotripsina apresenta dois barris$\beta$ em amarelo, dispostos em um ângulo reto entre si. O padrão cruzado das folhas $\beta$ pregueadas é denominado de Chave Grega (Greek Key). Apresentam 6 pontes dissulfetos em azul e $2 \alpha$-hélices em vermelho (figura 4 ).

As proteases desta família desempenham muitos papéis biológicos, principalmente na digestão ( $p . e x$. a tripsina e a quimotripsina), homeostase (fatores da coagulação), resposta imune mediada por IgA ( $p . e x$. a triptase e a chymase encontradas em células citotóxicas e em mastócitos) entre muitas outras atividades importantes. Por essa razão, elas têm relevância farmacêutica e biomédica como alvo de drogas, relacionadas à hemostase e ativação do sistema complemento.

As funções biológicas são tão diversas quanto os diferentes grupos que compõem a subfamília S1A, entre elas podem ser citadas: quimotripsinas, elastases, enteroquinases, calicreínas, fatores da coagulação do sangue VII, IX, X, XI e XII, trombina, plasminogênio e proteina $C$, além das proteases do veneno de serpentes, tais como: ancrod, batroxobin, flavoxobin, toxina ativadora de proteina $C$, crotalase, etc. 
As serino proteases de venenos de serpentes (SVSPs - Snake venom serine protease) apresentam muitas destas funções, sendo bem estabelecidas as ações na cascata da coagulação, conforme ilustrado para algumas toxinas mostradas na figura 5 .

\subsection{2-Serino proteases no veneno da cascavel Crotalus durissus terrificus.}

Até o momento, apenas duas serino proteases foram isoladas e caracterizadas no veneno de Crotalus durissus terrificus: a giroxina (BARRABIN et al.;1978; SEKI et al.,1980) e uma enzima trombina símile (RAW et al.,1986, BERCOVICI et al, 1987 e RUIZ DE TORRENT et al, 2007). Apenas para a giroxina há dados sobre a seqüência, embora ainda parciais, ou seja, dos 30 aminoácidos $\mathrm{N}$-terminal (DA SILVA et al.,1989) (figura 6).

\subsubsection{1-Trombina-símile.}

RAW et al, 1986, demonstraram que a enzima trombina símile e a giroxina se separam em picos diferentes no fracionamento do veneno bruto com sulfato de amônio. Mas como não estão totalmente seqüenciadas podem ser isoformas de uma mesma proteína.

A enzima trombina símile descrita comportou-se como uma proteína de cadeia única com peso molecular de $34 \mathrm{kDa}$ determinado em eletroforese de gel de poliacrilamida (SDS-PAGE). No teste de coagulação clivou apenas a cadeia $A \alpha$ do fibrinogênio humano e o pH ótimo foi 8 . 0 tempo de coagulação do plasma variou para diferentes espécies sendo em ordem crescente rato, homem, coelho e cavalo.

De acordo com RUIZ DE TORRENT et al, 2007, a enzima trombina símile do veneno de C.d.terrificus apresenta efeitos neurotóxicos, mas não ocasiona o rolamento em barril.

\subsubsection{2-Giroxina.}

De acordo com CAMILLO et al, 2001, a giroxina corresponde a 2,5\% da quantidade total de proteínas deste veneno. Em um fracionamento do veneno total o pico referente à giroxina apresenta contaminantes que provavelmente estão relacionados a associações entre moléculas da própria giroxina formando dímeros, ou à formação de complexos entre a giroxina e 
outras proteinas do veneno resultando em "agregados" com diferentes tamanhos moleculares (CAMILLO et al, 2001, BARRABIN et al, 1978). Este dado sugere que a ligação existente é fraca e com a adição de ureia ou $\beta$ mercaptoetanol ocorre a dissociação, confirmando tratar-se de uma proteína de cadeia única. A giroxina, após ser purificada por gel filtração e afinidade, apresentou por análise de eletroforese em gel SDS-PAGE com $\beta$ mercaptoetanol o peso molecular entre 30 e $36 \mathrm{kDa}$.

-Efeito Hemotóxico - Algumas SVSPs de serpentes são classificadas como trombina-símile, pois também são enzimas que agem na coagulação mimetizando a ação da trombina (uma enzima multifuncional), promovendo a conversão do fibrinogênio em fibrina. No entanto, a maioria destas enzimas (denominadas de venombina $A$ ) atuam liberando apenas o fibrinopeptídeo (FPA) da cadeia $A \alpha$ do fibrinogênio, produzindo apenas o monômero de fibrina ("rede frouxa") que não liga o fator XIII, portanto não há formação do polímero. Algumas poucas SVSPs clivam o fibrinogênio formando FPBfibrinopeptídeo $B$ (denominadas de venombina $B$ ) ou ambos (venombinas $A B$ ) mas não com a mesma eficiência quando comparadas à trombina. (MARSH, 1998, SERRANO \& MAROUN, 2005, CASTRO et al, 2004) (figura 7).

A giroxina é uma serino protease trombina-símile com um único domínio tripsina semelhante ao subdomínio serina-protease da trombina. Apresenta atividades esterásica e amidásica (BARRABIN et al.,1978, ALEXANDER et al.,1988). Os resultados de nosso laboratório demonstraram a ação da giroxina clivando fibrinogênio e liberando preferencialmente o fibrinopeptídeo A (FPA). (ARRUDA PAES et al.,1996).

-Efeito neurotóxico - A giroxina além de atuar sobre a coagulação apresenta uma marcante atividade neurotóxica diferenciando das outras SVSPs; gera uma síndrome que ocasiona um rolamento em barril. Este comportamento também foi descrito até hoje para as serino proteases crotalase (Crotalus atrox), ancrod (Agkistrodon rhodostoma) e análogo de giroxina (Lachesis muta muta) (ALEXANDER et al, 1988).

Esse efeito neurotóxico da giroxina do veneno crotálico foi descrita por BARRIO (1961). Após injeção endovenosa ou intraperitoneal em ratos e camundongos, induz sintomas como a falta de coordenação dos movimentos 
resultando em perda de equilíbrio, e após uma breve fase tônica o animal gira ao longo do eixo longitudinal do corpo lembrando o rolar de um barril (daí o nome "rolamento em barril"). O mesmo animal gira sempre para o mesmo lado com 3\% de exceções (WURPEL et al.,1986a). Alguns animais morrem, em geral por dificuldades respiratórias, enquanto outros se recuperam ficando completamente assintomáticos em aproximadamente 1 hora. Muitos animais que não desenvolvem a rotação em barril apresentam um ou mais sintomas, tais como imobilidade, alguns graus de ataxia, exiensão dos membros posteriores e limpeza.

Outras características importantes do rolamento em barril são:

$\Rightarrow$ É um fenômeno tudo ou nada. Não apresentando relação dose/ resposta (WURPEL et al.,1986a).

$\Rightarrow$ Sofre sensibilização. Uma segunda injeção de arginina-vasopressina, via intracerebroventricular induz o rolamento em barril em um número maior de ratos e causa uma diminuição do tempo de latência em relação ao primeiro dia (WURPEL et al.,1986b; WILLCOX et al.,1992). No entanto, a síndrome do rolamento em barril não é induzida por uma nova injeção da giroxina logo após a recuperação do animal (ALEXANDER et al.,1988).

$\Rightarrow$ Ocorre degeneração do sistema nervoso. Análises histológicas do hipocampo de ratos após injeções intracerebroventricular de giroxina crotálica foram caracterizadas pelo aparecimento de danos neuronais presentes tanto no local da injeção quanto em áreas distantes do sítio de aplicação (MOREIRA, 1993).

Alguns autores sugeriram que esta síndrome seria semelhante à lesão labiríntica (BARRIO,1961; SEKI et al.,1980); enquanto que outros acreditam que teria um efeito indireto sobre o sistema nervoso central (ALEXANDER et al.,1988: DA SILVA et al.,1989). Esta hipótese parece ser a mais provável, pois CAMILLO et al 2001 demonstraram que a giroxina não modifica a liberação in vitro de dopamina ou acetilcolina em tecido estriatal de ratos ou de camundongos.

A giroxina por ser uma serino protease, pode estar correlacionada com os receptores PARs (protease activated receptors), uma vez que as atividades fisiológicas das serino proteases, como trombina, tripsina e enzimas trombinasímiles são mediadas por estes receptores. Os PARs foram descritos em cérebros de mamíferos e a sua ativação faz com que algumas serino proteases 
aumentem a permeabilidade das células endoteliais. Esses receptores podem estar correlacionados com a neurotoxicidade da giroxina. (ALVES DA SILVA et al, 2006). No entanto o mecanismo pelo qual a giroxina induz o rolamento em barril assim como os processos patológicos envolvidos nesta síndrome ainda são desconhecidos.

A caracterização bioquímica da giroxina irá permitir realizar estudos mais detalhados de estrutura-atividade. Neste sentido, a biologia molecular tem muito a contribuir, pois possui ferramentas para determinar a organização gênica desta toxina, o precursor (pois a toxina é secretada na forma de um zimógeno inativo que posteriormente é clivada por autocatálise) e definir a estrutura primária da toxina madura que ainda é desconhecida, ou seja, contribuir para resolver questões que até hoje não tem respostas.

\section{3-Serino proteases recombinantes dos venenos de serpentes.}

As enzimas trombinas-símiles dos venenos de serpentes apresentam 12 resíduos de cisteinas e formam 6 pontes dissulfetos. As toxinas secretadas pelo epitélio glandular sofrem modificações pós traducionais como clivagem do peptídeo sinal, maturação no complexo de Golgi com a conseqüente glicosilação e o processamento do pró-peptídeo (ativação do zimógeno). Estas são características de proteínas secretadas eucarióticas. Portanto, o sistema de expressão recombinante tem de ser igualmente apto em realizar essas funções.

\section{4- Glicosilação.}

A giroxina purificada do veneno de Crotalus durissus terrificus apresenta 3,8\% de açúcares totais (CAMILLO et al, 2005).

A maioria das SVSPs é $\mathrm{N}$-glicosilada, com exceção da trombina-símile contortrixobin de Agkistrodon contortrix contortrix e flavoxobin de Trimeresurus flavoviridis (AMICONI et al, 2000). A glicosilação pode variar conforme a posição da asparagina e não são bem caracterizadas quais são as cadeias de açúcares presentes.

As serino proteases I e II do veneno de Agkistrodon acutus (AaV-SP-I e AaV-SP-II) são descritas por serem pouco glicosiladas na asparagina $35 . \mathrm{Na}$ figura 35 é mostrado o modelo da DAV-PA (Aav-SP-II) contendo a glicosilação na asparagina 35 com o monossacarídeo $N A G^{301}$. A serino protease AaV-SP-I 
apresenta $9 \%$ de carboidratos sendo descrita por apresentar o trissacarídeo $N G^{301}$-FUC- ${ }^{302}-N^{-} G^{303}$ ( $N$-acetil- $\beta$-glicosamina) e a serino protease AaV-SP-II apresenta $4 \%$ de carboidratos apresentando um monossacarídeo $N A G^{301}$. No entanto, esses carboidratos se encontram próximos do sítio ativo e os diferentes tipos de açúcares influenciam a estrutura do sítio ativo e conseqüentemente, resultam na alteração da atividade amidolítica (ZHU et al, 2005).

Duas proteínas muito parecidas em sua função apresentam quantidades de açúcares muito diferentes, como a toxina ancrod (Agkistrodon rhodostoma) e batroxobin (B. moojeni) - ambas são $\mathrm{N}$-glicosiladas, mas possuem respectivamente $31 \%$ e $5,8 \%$ de massa de carboidratos neutros. Estudos estruturais mostraram que os 5 sítios de $\mathrm{N}$-glicosilação da ancrod apresentam um padrão heterogềneo de glicoproteína sendo a maioria açúcares complexos di-tri- e tetra antena do tipo 1 (Galß3GlcNacB), Nacetilagalactosamina sialidada e uma pequena proporção de oligossacarídeos ( 2 a $3 \%$ dos açúcares totais) apresentam um braço NeuAc $\alpha 3$ GalNAc $\beta 4$ GICNAC.

A batroxobin do veneno da serpente Sul Americana Bothrops moojeni (que é uma glicoproteína com propriedades enzimáticas muito próximas da ancrod) apresenta açúcares complexos diantena, carregando exclusivamente a antena GalNAc $\beta 4 \mathrm{GICNac}$, sendo uma pequena parte substituída por Neu5Ac ou Neu4,5Ac2 com adição de resíduos fucose e uma pequena quantidade de espécies híbridas (LOCHNIT \& GEYER, 1995).

Qual o papel dos açúcares na atividade biológica? Será que as diferenças na glicosilação entre duas toxinas, com funções biológicas muito próximas e comercialmente usadas como agentes anticoagulantes, podem contribuir para que o ancrod ocasione o rolamento em barril não descrito para a batroxobin? Esta ainda é uma questão em aberto, pois entre as toxinas que causam o rolamento em barril, a crotalase e a giroxina são pouco glicosiladas em contraste com o ancrod que é muito glicosilado.

A importância da glicosilação foi também descrita para metaloproteases. De acordo com GARCÍA et al, 2004, a N-glicosilação da jararagina e da ACLH (que são metaloproteases hemorrágicas do veneno de Bothrops jararaca e de Agkistrodon contortrix laticinctus, respectivamente) é fundamental para a atividade hemorrágica. Essas toxinas foram expressas em E.coli e após o refolding da proteína recombinante não foi verificada a 
atividade. Da mesma forma, as toxinas nativas deglicosiladas também perderam a atividade, no entanto, a presença da atividade proteolítica sobre 0 fibrinogênio foi mantida. A ACLH apresenta o ácido siálico terminal $\alpha(2-6)$ ligado a uma galactose na cadeia de $\mathrm{N}$-glicosilação.

\subsection{Sistemas de expressão de proteína recombinante.}

\subsection{1- Sistema de expressão em Escherichia coli.}

As produções dessas enzimas em sistemas procarióticos resultam em sua maioria, na formação de corpos de inclusão como o obtido para a batroxobin de Bothrops atrox (MAEDA et al, 1991) e acutina de Agkistrodon acutus (PAN et al, 1999).

Segundo YUAN et al, 2004, a expressão de uma trombina-símile em E.coli DE3 gera a formação de corpúsculo de inclusão por tratar-se de uma proteína eucariótica rica em cisteínas, logo com muitas pontes dissulfetos. Para tentar solucionar este problema, os autores fizeram uma co-expressão juntamente com a tiorredoxina (TrxA) e obtiveram a caiobina-T - uma enzima trombina símile da serpente Agkistrodon caliginosus na forma solúvel. No entanto, a proteína recombinante apresentou baixa atividade amidolítica em substrato sintético devido à má formação das pontes dissulfeto. Em uma segunda abordagem, a isomerase dissulfídica (DsbC) foi introduzida na célula hospedeira e coexpressou juntamente com a calobina na presença de TrxA formando a calobina-TD. Com este sistema obteve-se um aumento da solubilidade e da atividade enzimática, mas ainda foi mantida baixa a atividade amidolítica. No entanto, ambas as formas recombinantes apresentaram atividade enzimática sobre fibrinogênio embora o produto obtido fosse isento da capacidade de coagulação; a ação da calobina TD foi maior do que a calobina-T.

Em um sistema de expressão em E.coli, através de um método inovador, HUNG e CHIOU 2000 expressaram a serino protease Tm-5 da serpente Trimeresurus mucrosquamatus com atividade calicreína símile. No sistema de expressão colocaram a cauda de polihistidina ligada a um sítio autocatalítico que pode ser clivado especificamente pela serino protease. Esta montagem resultou em uma enzima recombinante ativa, mas com um baixo rendimento $(2 \%)$, indicando uma baixa eficiência no processo de "refolding" da proteína. 
MEMARI et al 2006, utilizaram a expressão da serino protease calicreína 9 de tecido humano (KLK9) em E.coli, purificada e utilizada para a obtenção de um imunógeno adequado para produzir anticorpos monoclonais. Neste trabalho também foram apresentados resultados referentes à clonagem e expressão desta enzima, contendo o pre-pro peptídeo, em células $\mathrm{CHO}$. O rendimento foi $200 \mu \mathrm{g} / \mathrm{L}$ e a proteína recombinante apresentou massa molecular maior do que a produzida em E.coli, provavelmente devido à presença da cadeia glicosídica.

\subsection{2- Sistema de expressão em eucarioto.}

\subsubsection{1-Pichia pastoris.}

A expressão da batroxobin (enzima trombina símile da serpente Bothrops atrox moojeni) em um sistema de expressão eucarioto na levedura Pichia pastoris resultou em uma proteina recombinante ativa e obtida com bom rendimento $(7 \mathrm{mg} / \mathrm{L}$ do meio de cultura, com rendimento de $53,2 \%$ ). Nos testes de atividade enzimática pro-coagulante in vitro e in vivo, a enzima foi ativa pois ocasionou uma diminuição da concentração do fibrinogênio no plasma de rato, assim como, reduziu o tempo de sangramento da cauda e o tempo total de coagulação. No entanto houve uma diferença na massa molecular em relação à toxina nativa. A toxina nativa apresentou $37 \mathrm{kDa}$, enquanto que a batroxobin recombinante apresentou 33kDa. Esta diferença foi atribuída à diferença de glicosilação realizada pela levedura, que é diferente da realizada pela glândula da serpente. A batroxobin recombinante expresso pela Pichia pastoris pareceu apresentar estruturas de carboidratos típicos de levedura (YOU et al, 2004).

\subsubsection{2-Célula de mamífero.}

Há poucos trabalhos sobre expressão de SVSPs em células de mamiferos. Um é referente ao ativador de protrombina presente no veneno da Pseudonaja textilis, que foi expresso em célula de rim humano (H293F). Nesta construção, o cDNA completo codifica para o peptídeo sinal, propeptídeo, cadeia leve e cadeia pesada relacionada com 0 fator $X$ de mamífero. A expressão eficiente da protease foi alcançada em construções em que o peptídeo sinal foi deletado e o sítio de clivagem entre a cadeia leve e a cadeia pesada foi modificado, ou o peptídeo sinal foi substituído por um peptídeo 
envolvido no processamento de receptor de insulina. A protease foi expressa ocasionando uma eficiente coagulação do sangue e do plasma (FILIPPOVICH et al, 2005).

A Bothrojaracin do veneno de Bothrops jararaca é um potente inibidor de trombina. Essa protease recombinante foi expressa em célula de rim de macaco COS-7, sendo secretada para o meio de cultura com a capacidade de se ligar e inibir a trombina (AROCAS et al, 1997).

As referências comentadas acima evidenciam a dificuldade de se expressar uma SVSP com rendimento aceitável e com estrutura e atividade similar à proteína nativa. Observamos que expressar em um sistema procarioto é problemático devido à presença das pontes dissulfetos que dificultam a obtenção da toxina na conformação correta, portanto em sua forma ativa; assim como não ocorre o processamento pós traducional, como a glicosilação, que parece ser essencial para a atividade biológica.

\section{6- Aplicações das serino proteases do veneno de serpente em saúde.}

Com relação às serino proteases do veneno de serpente, há um interesse comercial para tratamento clínico de infarto do miocárdio, tromboses em veias profundas, pancadas ou embolia pulmonar (MARKLAND,1988). As enzimas trombina-símile denominadas de venombina $A$ comercialmente disponiveis são: ancrod (Arvin ${ }^{\circledR}$ da Agkistrodon rhodostoma) sendo eficaz em limitar o volume do infarto; batroxobin (Defibrase ${ }^{\circledR}$ da Bothrops moojeni), sendo utilizado para remover o fibrinogênio do plasma, crotalase (de Crotalus atrox). Outras SVSPs que atuam sobre o fibrinogênio são: análogo da giroxina (Lachesis muta muta), acutobin (Agkistrodon acutus), bothrombin (Bothrops jararaca).

Segundo THOMAZINI-SANTOS et al.,2001, há uma aplicação em fase experimental referente a utilização em cirurgias da fração trombina-símile isolada do veneno de Crotalus durissus terrificus em conjunto com o fibrinogênio animal, com o intuito de produzir uma "cola de fibrina" que pode usada com alternativa à sutura tradicional capaz de reduzir a morbidade no pós-operatório e excelentes resultados em feridas com cicatrização difícil como em câncer de pele, cirurgias cardíacas, fístulas estomacais e intestinais, entre outros e melhores efeitos cosméticos evitando a formação de quelóides. 
Estudos com SVSPs demonstraram que além de ser trombina-símile, apresentam diversas outras atividades específicas, tais como ativadores de plasminogênio: LV-PA (Lachesis muta muta), TSV-PA (Trimeresurus stejnegeri), PA-BJ (Bothrops jararaca); ativadores de proteína C: como a toxina ativadora de proteina $C$ de Agkistrodon contortrix contortrix (ACC-C) que é uma enzima trombina-símile comercialmente vendida (Protac ${ }^{\circledR}$ da Agkistrodon contortrix), um anticoagulante utilizado para inibir a oclusão das artérias em como em pacientes que possuem válvulas artificiais ou que sofreram cirurgias cardíacas ( $\mathrm{KOH}$ et al, 2006). 


\section{OBJETIVOS}

Neste sentido, esperamos ter deixado claro a importância das SVSPs e as aplicações em saúde, a atividade sobre diversos sistemas biológicos e a peculiaridade da giroxina em induzir o rolamento em barril, as lacunas na caracterização de serino proteases do veneno da mais abundante cascavel brasileira e finalmente a ausência de um sistema de expressão adequado para esta classe de enzimas.

Assim como objetivo geral, o presente trabalho visa contribuir com a clonagem e seqüenciamento da giroxina e possíveis variantes e desenvolver um sistema de expressão de serino protease de venenos de serpente na sua forma ativa, com as pontes dissulfetos e modificações pós traducionais, expressando-a em células de mamíferos.

De modo específico os objetivos são:

- Obter a seqüência da giroxina e a organização do cDNA a partir de uma biblioteca de cDNA de uma glândula de veneno de Crotalus durissus terrificus.

- Pesquisar a presença de variantes da giroxina nesta biblioteca.

- Analisar as seqüências obtidas por similaridade em bancos de dados e correlacionar a função e a estrutrura tridimensional.

- Clonar e expressar a giroxina em célula de mamífero.

- Isolar e verificar a atividade da giroxina recombinante. 


\section{MATERTAL EYMÉTTODOS}

\subsection{MATERIAIS}

$\checkmark$ A água utilizada em todos os experimentos foi purificada em sistema MILLI Q (18 $\Omega)$.

$\checkmark$ Todos os reagentes foram de pureza grau analítico ou grau de biologia molecular.

$\checkmark$ Todos os seqüenciamentos foram realizados pelo serviço de seqüenciamento do Centro de Estudos do Genoma Humano-Instituto de Biociências (USP) (protocolo descrito no apêndice 9.5).

\subsubsection{Materiais utilizados nos ensaios de Biologia Molecular, Cultura} de Células e Análises de Proteínas.

$\checkmark$ Agarose, Grau Biologia Molecular, (BioRad).

$\checkmark$ Linhagens de bactérias E.coli (vide tabela 5):

-TOP 10, DH5 $\alpha-T 1 R$, adquiridos no kit PCR2.1 TOPO

(Invitrogen).

- Hb 101 (ATCC).

-NIH RZ 1032 (ATCC).

$\checkmark$ Biblioteca de CDNA da glândula da serpente Crotalus durissus terrificus preparada pelo método descrito $\mathrm{em}$ RÁDIS-BAPTISTA et al, 1999 e gentilmente cedida pelos autores.

$\checkmark$ Desoxinucleotídeos - dATP, dCTP,dGTP e dTTP (Invitrogen).

$\checkmark$ Enzimas utilizadas para clonagens, subclonagens, ligação inserto/vetor, fosforilação de primer e manipulação de RNA, vide tabela 4.

$\checkmark$ Kit SuperScript III First-Strand Synthesis System for RTPCR (Invitrogen).

$\checkmark$ kits de Purificação de DNA plasmidial:

-S.N.A.P Miniprep (Invitrogen). 
-WizardPlus S. V. Minipreps (Promega).

Kits de purificação do DNA em gel de agarose:

-S.N.A.P UV-FREE Gel Purification (Invitrogen).

-QIAquick Gel Extraction (Quiagen).

LipofectamineTM 2000 (Invitrogen).

$\checkmark$ Marcadores de pares de bases de DNA:

-1kb Plus DNA Ladder -100pb a $12 \mathrm{~kb}$ (Invitrogen).

$-\lambda$ DNA/Hind III fragments- $125 \mathrm{pb}-23,1 \mathrm{~kb}$ (Invitrogen).

-250 pares de bases -250 a 3,5kb (Invitrogen).

$\checkmark$ Os vetores utilizados (vide apêndice 9.4 e tabela 1 ):

-pCR2.1 TOPO (Invitrogen).

-pSecTag2Hygro A (Invitrogen).

-pED cedido gentilmente por Kauffman (Kauffman, 2000).

-pEGFP-N1 (Biosciences Clontech).

$\checkmark$ Primers utilizados para clonagem e seqüenciamento, mutagênese e RT-PCR, vide tabela 2.

$\checkmark$ Primers comerciais:

- M13 sense, M13 antisense, T3 sense, T7 antisense, vide tabela 3.

Linhagens celulares:

- células de ovário de hamster chinês deficientes no gene da enzima diidrofolato redutase CHO DXB11 dhfr- gentilmente cedida pelo Dr. L. Chasin (Columbia Univesity, NY, EUA); CHO-K1 dhfr+ (ATCC:CRL-9618) e célula de rim de macaco COS-7 (Cercopithecus aethiops) (ATCC: CRL-1651).

$\checkmark$ Meio mínimo essencial $\alpha$-MEM contendo $10 \mathrm{mg} / \mathrm{L}$ de ribonucleosídeos e desoxiribonucleosideos (Cultilab).

$\checkmark$ Meio mínimo essencial $\alpha$-MEM na ausência de ribonucleosídeos e desoxiribonucleosídeos (Cultilab). 
Meio D-MEM- High Glucose (Invitrogen).

$\checkmark$ Soro fetal bovino (Cultilab).

$\checkmark$ Soro fetal bovino dialisado (Life Technologies).

$\checkmark$ Tripsina (Sigma).

$\checkmark$ Penicilina (Invitrogen).

$\checkmark$ Estreptomicina (Invitrogen).

$\checkmark$ Anfotericina B-fungizona (Invitrogen).

$\checkmark$ L-glutamina (Gibco).

$\checkmark$ Veneno liofilizado de Crotalus durissus terrificus e antisoro crotálico gentilmente cedido pelo Instituto Butantan.

$\checkmark$ Anticorpo anti-IgG eqüina biotinilada feito em coelho conjugada com peroxidase (Sigma).

$\checkmark$ Kit ECL + PLUS quimioluminescente- Western blotting detection system (Amershan Pharmacia).

$\checkmark$ Marcador de peso molecular Low-Range Rainbow Molecular Weight Marker (45KDa - 2,5KDa) (Amersham Biosciences).

$\checkmark$ Membrana de nitrocelulose-Hybond-ECL, (Amershan Biosciences).

$\checkmark$ Resina benzamidina sepharose 4B (Benzamidine Sepharose $4 B$ Fast Flow) (Amershan Biosciences).

$\checkmark$ TAME (N-tosyl-arginina-metil éster) (Sigma).

$\checkmark$ Trizol (Invitrogen).

\subsubsection{Equipamentos.}

$\checkmark$ Agitador (Tayo Rotator).

$\checkmark$ Aparelho Mili-Q-plus, purificador de água (Millipore).

$\checkmark$ Autoclave, modelo SS-245E (Tomy).

$\checkmark$ Banho-maria, modelo 100, (Fanem).

$\checkmark$ Cubeta de eletroporação (BioRad).

$\checkmark$ Electroporador, modelo II (Invitrogen).

$\checkmark$ Espectrofotômetro (Beckman).

$\checkmark$ Estufa bacteriológica (QUIMIS).

$\checkmark$ Freezer $-80^{\circ} \mathrm{C}$, modelo 939 (Forma Scientific, Inc)

$\checkmark$ Fluxo laminar modelo 2256 (TROX).

$\checkmark$ Image Master VDS (Amershan pharmacia). 
$\checkmark$ Incubadora refrigerada com agitação, modelo TE421 (TECNAL).

$\checkmark$ Integrated Speed Vack System, Farmingdale, NY (Savant Instruments INC).

$\checkmark$ Microscópio invertido, modelo TMS (Nikon).

$\checkmark$ Microscópio óptico modelo Axioskop $40 \mathrm{FL}$ (Carl Zeiss).

$\checkmark$ PCR 240024 poços (Perkin Elmer Gene amplification).

$\checkmark$ Sistema de eletroforese horizontal- Submarine type electrophoresis system (MUPID-2plus).

$\checkmark$ Sistema de eletroforese vertical, modelo SE250, Hoefer (Pharmacia Biotech).

$\checkmark$ Sistema semi-seco de eletrotransferência (BioRad).

$\checkmark$ Sonicador, Danbury Connecticut U.S.A (Sonics \& Materials Inc).

\subsubsection{Ferramentas de Bioinformática.}

$\checkmark$ BLAST - Basic Local Alignment Search Tool $\left({ }^{1}\right)$ (BLASTnnucleotídeos e BLASTp-proteína).

$\checkmark$ CLUSTAL W: European Bioinformatics Institute Sequence Analysis $\left({ }^{2}\right)$

$\checkmark$ EXPASY - Expert Protein Analysis System- (Posttranslational modification prediction e Pattern and profile search-ScanProsite) $\left({ }^{3}\right)$

$\checkmark$ Fator de confiança do SWISS-MODEL (ProModII) $\left({ }^{4}\right)$

$\checkmark$ NetNGlyc 1.0 e NetOGlyc 3.1 presentes no site CBS - Center for Biological Sequence Analysis ( $\left.{ }^{5}\right)$.

$\checkmark$ MACAW (Multiple Alignment Construction \& Analysis Workbenck) (SCHULER et al, 1993)

$\checkmark$ PHYLIP (Phylogeny Inference Package) versão 3.2 (FELSENSTEIN, J. 1989).

$\checkmark$ Programa Graph Pad Prism $\left({ }^{6}\right)$

\footnotetext{
1 http://www.ncbi.nlm.nih.gov/BLAST

2 http://www.ebi.ac.uk

${ }^{3}$ http://www.expasy.org/tools/scanprosite/

${ }^{4}$ http://swissmodel.expasy.org//SWISS-MODEL.html

${ }^{5}$ http://www.cbs.dtu.dk/

${ }^{6}$ http://www.graphpad.com/
} 
$\checkmark$ Programa Phred $\left({ }^{7}\right)$ (EWING et al, 1988).

$\checkmark$ Programa WHAT IF $\left(^{8}\right)$

$\checkmark$ RCSB PDB - Research Collaboratory for Structural Bioinformatics - Protein Data Bank $\left({ }^{9}\right)$.

$\checkmark$ SignalP versão 3.0 Prediction of signal peptide cleavage sites presente no site CBS - Center for Biological Sequence Analysis $\left({ }^{10}\right)$

$\checkmark$ SPIDEY: mRNA to-genomic aligniment program created by WHEELAN, $S\left({ }^{11}\right)$

$\checkmark$ SWISS-MODEL $\left({ }^{12}\right.$ ) Programa DEEP VIEW versão 3.7 (Swiss Pdb-Viewer).

$\checkmark$ Método de minimização de energia utilizou-se o programa Gromos 96 (GUEX \& PEITSCH, 1997).

\footnotetext{
7 http://www.phrap.org/

8 http://swift.cmbi.kun.nl/whatif/

${ }^{9} \mathrm{http}: / /$ www.rcsb.org.

${ }^{10}$ http://www.cbs.dtu.dk/services/SignalP/

11 http:// www.ncbi.nlm.nih.gov/IEB/Research/Ostell/Spidey

12 http://swissmodel.expasy.org//SWISS-MODEL.html
} 


\subsection{MÉTODOS}

\subsection{Obtenção do clone pCR2.1 TOPO-B2.1.}

\subsubsection{Definição do primer GYR SE.}

Foram verificadas em banco de dados as seqüências de nucleotídeos (BLASTn) e proteínas (BLASTp) depositadas para serino proteases do veneno de serpentes.

O alinhamento de algumas destas e a comparação com a seqüência Nterminal de giroxina de Crotalus durissus terrificus descrito em DA SILVA et al, 1989 utilizando-se o CLUSTAL W, permitiu definir as tríades codantes mais freqüentes para cada aminoácido, a partir da qual foi desenhado um primer específico para a giroxina, sendo o primer GYR SE complementar aos 24 primeiros nucleotídeos da região que codifica o início do $\mathrm{N}$-terminal. A definição do primer se encontra na figura 8.

O PCR foi realizado com uma alíquota da biblioteca de CDNA da glândula de veneno de Crotalus durissus terrificus como DNA molde, o primer sense GYR SE e com o primer antisense T7 (que é complementar a uma região flanquedora do sitio de clonagem presente no vetor UniZAP XR). Foi utilizado a Taq DNA polimerase recombinante. Dessa forma, o produto amplificado corresponde à toxina madura e à região não traduzida $3^{\prime}$ UTR. A seqüência do primer GYR SE se encontra na tabela 2 e do primer antisense T7 na tabela 3 e a região de hibridação desses primers está representada na figura 9.

O produto de PCR foi analisado em gel de agarose 1,5\%, juntamente com o marcador de DNA de $1 \mathrm{~kb}$ Plus. Uma alíquota do produto de PCR (inserto) foi clonada no vetor pCR2.1 TOPO e o produto da reação de ligação vetor-inserto foi inserida em $E$. coli TOP 10 (bactéria quimicamente competente).

As colônias recombinantes (brancas) foram selecionadas da placa LB ${ }^{\text {AMP }}$ /X-gal e IPTG ágar e cresceram em meio líquido LBAMP por $24 \mathrm{~h}$ com agitação. Por meio de PCR de colônias (protocolo descrito no apêndice 9.1.7.3), com os primers universais M13 sense e antisense e análise em eletroforese em gel de agarose $1,5 \%$, foram identificados os clones recombinantes (com tamanhos aproximados de $1200 \mathrm{pb}, 900 \mathrm{pb}$ e $550 \mathrm{pb}$ ). 
As colônias recombinantes foram inoculadas separadamente em $3 \mathrm{~mL}$ de meio $L B^{A M P}$ e cresceram durante a noite com agitação (200rpm). Posteriormente foi realizada a extração do DNA plasmidial, purificação (kit S.N.A.P Miniprep) e seqüenciamento. Para a confirmação da seqüência foram necessários vários seqüenciamentos de cada clone.

\subsubsection{Análise de seqüências.}

Todas as seqüências obtidas nas diferentes etapas deste trabalho foram comparadas com banco de dados de seqüências de nucleotídos usando o programa BLASTn. As seqüências de aminácidos foram traduzidas usando a ferramenta do translate do EXPASY e submetidas a uma comparação com bancos de dados de proteínas usando o BLASTp.

A qualidade dos seqüenciamentos foi verificada pelo software Phred.

As informações sobre domínio da família, o sítio ativo, pontes dissulfetos e sítio de modificação pós traducional foram previstas utilizando-se a ferramenta de bioinformática EXPASY. Especificamente na predição da modificação pós traducional para os sítios potenciais de glicosilação foram utilizadas as ferramentas de bioinformática NetNGlyc 1.0 e NetOGlyc 3.1.

A predição do peptídeo sinal dos clones (quando presente) foi realizada utilizando-se o programa SignalP, específico para predição de seqüências sinais de secreção de proteínas de eucariotos.

As regiões correspondentes aos éxons nas seqüências dos clones de cDNA foram identificadas por comparação com o alinhamento do gene da batroxobin de Bothrops atrox (X12747) (ITOH et al,1988) utilizando-se o programa Spidey.

Os CDNA, as toxinas maduras dos clones obtidos e outras seqüências de serino proteases de venenos de serpentes foram alinhados utilizando-se 0 programa MACAW com a matriz BLOSUM 62.

O dendrograma do alinhamento das seqüências de cDNA foi realizado pelo programa PHYLIP, a matriz de distâncias foi calculada utilizando-se a ferramenta DNAdist. A categoria de substituição de nucleotídeos utilizada foi a F84 em que incorpora diferentes taxas de transição e transversão do DNA, mas também permite diferentes frequências para os 4 nucleotídeos. $A$ árvore foi construida pelo método de Neighbor-joining. 
Os dendrogramas do alinhamento das toxinas maduras traduzidas dos clones de cDNA, entre si, ou alinhando-se com toxinas homólogas de outras serpentes, foram realizados pelo programa PHYLIP e a matriz de distância foi calculada utilizando-se a ferramenta PROTdist. Para esta análise foi escolhida a categoria de substituição química de aminoácidos de Hall que organiza grupos com propriedades fisico-químicas similares: ácidos ou negativos (Glu, Gln, Asp, Asn), básicos ou positivos (Lys, Arg, His), aromáticos não carregados (Phe, Tyr, Trp), apolares hidrofóbicos (Met, Val, Leu, Ileu), polares não carregados (Gly, Ala, Ser, Thr), Cys e Pro. O método de construção foi Neighbor-joining.

Para se realizar os modelos tridimensionais da giroxina e Crotalase foi utilizada a ferramenta SWISS-MODEL e o programa DEEP VIEW e para o método de minimização de energia utilizou-se o programa GROMOS 96.

Os modelos cristalográficos do ativador de plasminogênio TSV-PA (1bqy) de Trimeresurus stejnejeri, das serino proteases AaV-SP-I (1op0) e AaV-SP-II/DAV-PA de Agkistrodon acutus (1op2), da tripsina bovina (2ptc) e da $\alpha$-trombina humana (1c50) foram obtidos no banco de proteínas RCSB PDB.

\subsection{Clonagem de isoformas de serino proteases similares a giroxina.}

\subsubsection{Obtenção dos clones pCR2.1 TOPO-GPSs.}

Com a finalidade de conhecer a seqüência a $5^{\prime}$ UTR- untranslated terminal region e a região codificante para o peptídeo sinal, para o prépeptídeo e para a toxina madura do clone da giroxina-símile foi realizado um PCR utilizando-se a Taq DNA polimerase Platinum, com os primers T3 sense (que é complementar a uma região flanquedora do sitio de clonagem presente no vetor UniZAP XR) e GYR AS1 que é complementar à região codificante do C-terminal da toxina imediatamente antes do stop códon. A seqüência do primer T3 se encontra na tabela 3 e do primer GYR AS1 na tabela 2 e a região de hibridação desses primers está mostrada na figura 10.

Os clones amplificados com esses primers foram denominados de giroxina peptídeo sinal (GPS) e não apresentam a região 3 'não traduzida ( $3^{\prime}$ UTR). 
A banda de maior peso molecular identificada pela análise em gel de agarose $1,5 \%$ foi recortada, purificada (kit S.N.A.P UV-FREE Gel Purification) e clonada no vetor pCR2.1 TOPO, sendo em seguida inserida em $E$. coli $\mathrm{DH} 5 \alpha-$ T1R (bactérias eletrocompetentes).

As colônias recombinantes (brancas) foram selecionadas da placa $\mathrm{LB}^{\mathrm{AMP}}$ /X-gal e IPTG ágar e incubadas no meio líquido LB $^{\text {AMP }}$ durante a noite com agitação (200rpm).

Através do PCR de colônias (protocolo descrito no apêndice 9.1.7.3), utilizando os primers universais M13 sense e antisense, em análise em eletroforese em gel de agarose $1,5 \%$ foram identificados os produtos de amplificação positivos (que apresentaram um tamanho de inserto de aproximadamente $1200 \mathrm{pb}$ ). $\mathrm{Em}$ seguida estes foram inoculados separadamente em $3 \mathrm{~mL}$ de meio $L^{A M P}$ e cresceram durante a noite com agitação. Após a extração e purificação (kit S.N.A.P Miniprep), o DNA plasmidial dessas bactérias foram enviados para seqüenciamento.

As seqüências de CDNA dos clones GPSs foram analisadas de forma similar ao descrito para o clone giroxina-símile, quanto à presença do peptídeo sinal e modificações pós traducionais e comparadas com homólogos presentes em banco de dados do Expasy.

O programa MACAW permitiu realizar o alinhamento com seqüências precursoras codificantes para o peptídeo sinal, própeptídeo e toxina madura. Com base neste alinhamento foi desenhado um primer peptídeo sinal PS que é complementar aos 18 primeiros nucleotídeos que codificam para a região do peptídeo sinal como mostrado na figura 21 e na tabela 2.

\subsubsection{Obtenção dos clones pCR2.1 TOPO-PST7s.}

Com a finalidade de conhecer a seqüência precursora completa do clone de giroxina-símile, foi realizado um PCR com a Taq DNA polimerase Platinum e os primers peptídeo sinal P.S sense e T7 antisense. Nessas condições de reação esses clones somente não apresentam a região 5 'UTR . A seqüência do primer peptídeo sinal PS se encontra na tabela 2 e do primer T7 na tabela 3 e a região de hibridação desses primers é mostrada na figura 11.

A banda de maior peso molecular obtida com o produto de PCR e identificada na análise em gel de agarose $1,5 \%$ foi recortada, com o auxílio de 
um estilete, purificada (kit S.N.A.P UV-FREE Gel Purification), clonada no PCR2.1 TOPO e inserida em E. coli. TOP 10 (bactérias eletrocompetentes).

Após crescimento e seleção dos clones recombinantes por PCR de colônias (conforme protocolo descrito no apêndice 9.1.7.3), as colônias que apresentaram bandas de DNA correspondente ao inserto de aproximadamente $1600 \mathrm{pb}$, foram cultivadas separadamente em $3 \mathrm{~mL}$ de meio LB $^{\text {AMP }}$, durante a noite com agitação. Após a extração do DNA plasmidial dessas bactérias (kit S.N.A.P Miniprep), o plasmídeo foi seqüenciado. Para obter as seqüências completas dos clones foi necessário sintetizar o primer interno antisense PST7 AS, que é complementar a região de 1006 a 1023pb do clone PST7:3. e seqüenciar os clones com os primers P.S e PST7 AS. As seqüências dos primers estão descritas na tabela 2.

Os resultados obtidos foram submetidos a uma comparação com bancos de dados de seqüências de nucleotídeos e proteínas usando os programas BLASTn e BLASTp e analisadas quanto à presença do peptídeo sinal e modificações pós traducionais por comparação com homólogos presentes em banco de dados do EXPASY.

A caracterização das regiões dos éxons foi realizada utilizando-se 0 programa Spidey conforme descrito no subitem 3.2.2- Análise de seqüências (página 21).

\subsection{Análise das seqüências de cDNA e de proteínas dos clones obtidos.}

\subsubsection{Alinhamento e Dendrograma.}

Os clones de CDNA obtidos foram alinhados no programa MACAW e o dendrograma foi realizado pelo programa PHYLIP conforme descrito no subitem 3.2.1.2- Análise de seqüências.

Posteriormente foram realizados os alinhamentos de nucleotídeos e aminoácidos evidenciando-se as similaridades e diferenças entre os clones.

\subsubsection{Análise dos precursores.}

O estudo das seqüências relacionadas aos precursores e toxinas maduras foram realizados por dois métodos: 1) por comparação das seqüências precursoras com toxinas maduras identificando-se o ponto de clivagem e 2) pela análise com o programa SignalP. 
1) Comparação das seqüências precursoras com toxinas maduras identificando-se o ponto de clivagem: para essa análise foi utilizado o programa MACAW comparando os clones com as seguintes sequências: Catroxase I de Crotalus atrox (AF227153.1); Serino protease 1 de Crotalus adamanteus (AJ251525.1); Protrimubin de Trimeresurus mucrosquamatus (U31417); Serino protease de Trimeresurus gramineus (D67083.1); Serino protease de Bothrops jararacussu (AY251282.1); HS 120 de Bothrops jararaca (AB178323.1); Precursor de Ancrod de Agkistrodon rhodostoma (P47797); (toxina madura) de Agkistrodon rhodostoma (P26324) conforme mostrado na figura 30.

2) Análise com o programa SignalP: a seqüência de um dos precursores foi analisada no programa SignalP permitindo identificar com uma melhor precisão o sítio de clivagem do peptídeo sinal conforme mostrado na figura 31.

\subsubsection{Análise das toxinas maduras.}

As toxinas maduras foram alinhadas pelo programa MACAW e construído um dendrograma com o programa PHYLIP.

\subsection{Comparação das toxinas maduras dos clones obtidos com outras} toxinas.

As 29 seqüências de serino proteases de venenos de serpentes escolhidas para a construção do dendrograma funcional, cujas características funcionais estariam relacionadas com as toxinas maduras dos clones obtidos, foram: Tripsina de suíno, Sus scrofa (P00761- HUANG et al 1993); FVA Factor V-activating enzyme, Vipera lebetina (Q9PT41-SIIGUR et al, 1999); RVV-Va Vipera russelli proteinase, Daboia russelli siamensis (P18964 - TOKUNAGA et al.1988); Catroxase-2, Crotalus atrox (Q8QHK2- BJARNASON et al, 1983); Dav-PA, Agkistrodon acutus (Q9I8X1- WANG et al, 2001); Flavoxobin, Trimeresurus flavoviridis (P05620-DESHIMARU et al, 1996); Contortrixobin, Agkistrodon contortrix contortrix (P82981- AMICONI et al, 2000); PA-BJ, Bothrops jararaca (P81824-SERRANO et al, 1995); LV-PA, Lachesis muta muta (P84036-SANCHEZ et al, 2000);TSV-PA, Trimeresurus stejnegeri (Q91516ZHANG et al, 1995); Calobin, Agkistrodon caliginosus (Q91053- HAHN et al. 1996); Pallabin-2, Agkistrodon halys pallas (Q9YGI6- FAN et al,1999); 
Halystase, Agkistrodon halys blomhoffii (P81176- MATSUI et al. 1998); KN-BJ, Bothrops jararaca (013069- SERRANO et al,1998); Venom serine proteinase $\mathrm{Sp} 1$, Crotalus adamanteus (Q8UUK2);Catroxase-1,Crotalus atrox (Q8QHK3); Elegaxobin-1, Trimeresurus elegans (P84788- OYAMA \& TAKAHASHI, 2002); Mucrofibrase-1, Trimeresurus mucrosquamatus (Q91507- HUNG et al, 1994); Dav-KN, Agkistrodon acutus (Q9I8X0-WANG et al, 2001); ACC-C Protein C activator; Agkistrodon contortrix contortrix (P09872- MCMULLEN et al, 1989); PST7: 7 e 8 de Crotalus durissus terrificus; CPI enzyme-2, Agkistrodon caliginosus (042207- HAHN et al, 1998); Bilineobin, Agkistrodon bilineatus (Q9PSN3- NIKAI et al, 1995); Gyroxin analog, Lachesis muta muta (P33589MAGALHÃES et al,1993); Ancrod, Agkistrodon rhodostoma (P26324 BURKHART et al,1992); Crotalase, Crotalus adamanteus (HENSCHEN-EDMAN et al,1999); PST7: 3 de Crotalus durissus terrificus; Gyroxin-like B2.1, Crotalus durissus terrificus (Q58G94); GPS: 2 e 5 de Crotalus durissus terrificus; PST7: 4 de Crotalus durissus terrificus; GPS: 3 e 4 de Crotalus durissus terrificus; Dav-X, Agkistrodon acutus (Q9I8W9-WANG et al, 2001); Acutobin, Agkistrodon acutus (Q9I8X2- WANG et al, 2001);TLG-2B, Trimeresurus gramineus (013061- DESHIMARU et al,1996); Bothrombin, Bothrops jararaca (P81661- NISHIDA et al, 1994); Batroxobin, Bothrops atrox (P04971- ITOH et al, 1987).

A seqüência de tripsina de suíno Sus scrofa foi utilizada como grupo externo uma vez que a árvore não tem raíz e sendo a tripsina a seqüência menos homóloga em relação as toxinas utilizadas, permitiram evidenciar melhor as similaridades existentes. Também foram eliminadas as sequências com similaridade acima de $90 \%$ entre si e os peptídeos sinais dos precursores realizando-se portanto, um alinhamento somente das sequências maduras buscando refletir a similaridade funcional da toxina tal como se encontra no veneno.

\subsection{Modelo tridimensional.}

Os modelos tridimensionais foram construídos por homologia utilizando-se a ferramenta SWISS-MODEL e o programa DEEP VIEW. Foram construídos para a Crotalase e giroxina-símile, tomando como base os dados cristalográficos do ativador de plasminogênio TSV-PA de Trimeresurus stejnejeri (1bqy), das serino proteases AaV-SP-I (10p0) e AaV-SP-II/DAV-PA 
(1op2) de Agkistrodon acutus. A qualidade dos modelos foi avaliada pelo programa WHAT IF e de acordo com o fator de confiança do SWISS-MODEL (ProModII).

Em seguida, foi realizada a comparação dos modelos tridimensionais obtidos com os modelos cristalográficos da tripsina bovina (2ptc), TSV-PA (1bqy), DAV-PA (1op2) e da região correspondente à cadeia pesada da $\alpha$ trombina humana (1c50) (aminoácidos 16 a 247).

\subsection{Construção do vetor de expressão pED-Giro.}

Para a expressão do inserto correspondente à toxina madura de giroxina-símile, o cDNA do clone B2.1 foi clonado no vetor pSecTag2hygro A, que contém o peptídeo sinal IgK. Foi realizada uma mutagênsese sítio dirigida para deletar os nucleotídeos presentes entre o peptídeo sinal IgK e o inserto giroxina-símile. Após essa deleção o inserto da fusão IgK-Giro foi clonado no vetor $\mathrm{pED}$, resultando no vetor $\mathrm{pED}$-Giro que possibilitou expressar o cDNA correspondente à toxina madura nas célula CHO-DXB11 e células COS-7 e secretar a toxina recombinante no meio de cultura.

É possível observar na figura 12 o esquema da construção do vetor de expressão pED-Giro. As condições de reação com as enzimas de restrição, de modificação e amplificação de DNA estão especificadas na tabela 4 e apêndice 9.3 .

O clone giroxina B2.1 escolhido para a expressão contendo um inserto de $1200 \mathrm{pb}$ foi obtido com os primers GYR SE e T7 antisense conforme descrito no subitem 3.2.1.1. Definição do primer GYR SE.

\subsubsection{Obtenção do inserto da giroxina madura.}

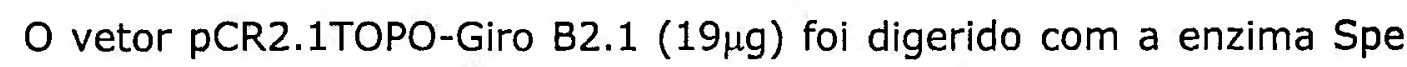
I. Em seguida, o DNA foi purificado por fenol/clorofórmio e precipitado de acordo com o protocolo descrito na apêndice 9.1.6, inativando-se a enzima. Ressuspendeu-se em $85 \mu$ de água.

Posteriormente $16 \mu \mathrm{g}$ do vetor linear foi tratado com o fragmento de Klenow da DNA polimerase, juntamente com $0,05 \mathrm{mM}$ dos 4 dNTPs, para preencher a extremidade coesiva obtendo-se uma extremidade de ponta cega. Após a inativação da enzima por calor, o DNA foi precipitado e ressuspenso em $15 \mu \mathrm{L}$ de água destilada. 
O vetor linearizado PCR2.1TOPO-Giro $(20 \mu \mathrm{g})$ foi a seguir digerido com a enzima de restrição Not I e o produto da digestão analisado em gel de agarose $1 \%$ na qual se esperava obter dois fragmentos: 0 vetor $\mathrm{e} o$ inserto correspondente a giroxina-símile com extremidade coesiva Not I a $5^{\prime}$ e uma extremidade cega a $3^{\prime}$ utilizado como inserto para se ligar no vetor pSecTag2hygro A.

A banda de DNA do inserto giroxina-símile foi recortada do gel de agarose $1 \%$ e purificada (kit S.N.A.P-UV-FREE Gel Purification). A recuperação do inserto foi confirmado por nova análise em gel de agarose $1 \%$.

\subsubsection{Preparo do vetor pSecTag2 Hygro $A$.}

O vetor pSecTag2hygro A $(3 \mu \mathrm{g})$ foi digerido com a enzima de restrição Xho I. Em seguida o DNA foi purificado por fenol/clorofórmio e precipitado de acordo com o protocolo descrito no apêndice 9.1.6, inativando a enzima. 0 DNA foi ressuspenso em $26 \mu l$ de água destilada.

Posteriormente $2,9 \mu \mathrm{g}$ de vetor linear foi tratado com o fragmento de Klenow da DNA polimerase I, juntamente com 0,05mM dos 4dNTPs, para preencher a extremidade coessiva e obter uma extremidade de ponta cega. Em seguida a enzima foi inativada por calor. O DNA foi precipitado e ressuspenso em $25 \mu \mathrm{L}$ de água destilada.

Posteriormente $4 \mu \mathrm{g}$ de vetor linear foi digerido com a enzima de restrição Not I. Após esta reação inativou-se a enzima por calor, obtendo-se um fragmento do vetor com a extremidade coesiva Not I a $5^{\prime}$ e uma extremidade cega a $3^{\prime}$ para ligar com 0 inserto giroxina-símile com extremidades compatíveis.

\subsubsection{Ligação do inserto giroxina-símile em pSecTag2Hygro A e seleção do clone pSecTag2-Giro.}

$O$ inserto giroxina-símile com extremidade Not I a $5^{\prime}$ e extremidade cega a $3^{\prime}$ foi ligado ao vetor pSecTag2/Hygro A, linearizado com os mesmos tipos de extremidades, permitindo a subclonagem direcional do inserto.

Após a ligação com a enzima T4 DNA ligase, foi realizada a transformação em $E$. coli TOP 10 (bactéria quimicamente competente). Após o crescimento das colônias recombinantes em placas LB $^{\text {AMP }}$ - Agar e seleção dos clones por tamanho de plasmídeo recombinante (protocolo descrito no 
apêndice 9.1.7.2), a amostra que apresentou uma migração aparente maior do que o tamanho do vetor vazio (não recombinante) é provavelmente o pSecTag2-Giro.

A construção do vetor pSecTag2-Giro foi confirmada por PCR de colônias (protocolo descrito no apêndice 9.1.7.3) utilizando-se os primers GYR SE e GYR AS1 tendo como amostras uma alíquota da suspensão bacteriana contendo o plasmídeo recombinante, como controles negativos três clones não recombinantes e o vetor vazio não recombinante. Essas amostras foram analisadas em gel de agarose $1,5 \%$.

O clone positivo (pSecTag2-Giro) foi crescido em meio LB ${ }^{\text {AMP }}$ durante a noite com agitação, para posterior extração do DNA plasmidial (kit WizardPlus S. V. Minipreps).

\subsubsection{Mutagênese sítio dirigida}

\subsubsection{Preparo de DNA de fita simples.}

A produção de DNA de fita simples, baseada em KUNKEL 1985, foi realizada com a intenção de deletar a seqüência intervalar entre IgK e giroxina

Este método utiliza a bactéria $E$. coli RZ1032 que é uma linhagem deficiente na enzima dUTPase (produto do gene dut). Esta característica resulta no aumento intracelular de dUTP, que compete pelo dTTP na incorporação ao DNA. A uracila incorporada não é retirada devido à deficiência da enzima uracila glicosilase, enzima esta (produto do gene ung) responsável por retirar as bases uracilas incorporadas erroneamente ao DNA, trocando-as por timidina, dessa forma a fita simples produzida terá uracila no lugar de timidina.

Uma alíquota de $80 \mu \mathrm{L}$ de E.coli RZ1032 (dut'/ ung-) (bactéria eletrocompetente) foi transformada com $2 \mu \mathrm{L}$ do DNA plasmidial purificado do clone pSecTag2-Giro. A colônia recombinante (pSecTag2-Giro) selecionada da placa $\mathrm{LB}^{\mathrm{AMP}}$ - ágar foi incubada em meio $\mathrm{YT}$ acrescido de ampicilina $(50 \mu \mathrm{g} / \mathrm{mL})$, durante a noite, a $37^{\circ} \mathrm{C}$ com agitação de $200 \mathrm{rpm}$.

Posteriormente $15 \mu \mathrm{L}$ desta cultura foram adicionados em $1,5 \mathrm{~mL}$ de meio $Y T$, cultivando-se nas mesmas condições até atingir a densidade óptica de $0,2 \mathrm{em} 600 \mathrm{~nm}$. Adicionaram-se $10 \mu \mathrm{L}$ do fago auxiliar R408 para ativar a origem de replicação ( $f 1$ ) do vetor e sintetizar a fita simples de DNA contendo uracila. Incubou-se a $37^{\circ} \mathrm{C}$, com agitação de $200 \mathrm{rpm}$, durante um período de 
5 a 6 horas. Após este período, centrifugou-se a cultura a $12.000 \mathrm{rpm}$ por 5 minutos e o sobrenadante foi transferido para um novo tubo de centrífuga.

0 DNA do sobrenadante foi precipitado acrescentando-se $200 \mu \mathrm{L}$ de uma solução PEG 8000 a $20 \%$ em NaCl 2,5M. Agitou-se por inversão e incubou-se por 15 minutos a temperatura ambiente. Após este período a cultura foi centrifugada a $12.000 \mathrm{rpm}$ por 5 minutos, descartado o sobrenadante e o precipitado foi ressuspenso em $100 \mu \mathrm{L}$ de TE (Tris EDTA).

Essa solução contendo o DNA de fita simples foi purificada por fenol clorofórmio e o DNA foi precipitado, sendo ressuspendido em $15 \mu \mathrm{l}$ de TE e estocado a $-20^{\circ} \mathrm{C}$. A confirmação da presença do DNA simples fita (sfDNA) foi obtida por uma análise em gel de agarose $0,6 \%$.

\subsubsection{Fosforilação do primer.}

A fosforilação de $1 \mu \mathrm{L}$ do primer para a mutagênese (200 pmoles $/ \mu \mathrm{L}$ ) foi realizada a $37^{\circ} \mathrm{C}$ por 45 minutos com $2 \mu \mathrm{L}$ de $1 \mathrm{X}$ tampão kinase (10X Tris $\mathrm{HCl} \mathrm{pH} \mathrm{8,0;100mM} \mathrm{MgCl} ; 50 \mathrm{mM} \mathrm{DTT;} \mathrm{4mM} \mathrm{ATP),} 30$ unidades da enzima $\mathrm{T}_{4}$ polinucleotídeo kinase, completando com água para uma reação final de $20 \mu \mathrm{L}$. Após este período a enzima foi inativada a $65^{\circ} \mathrm{C}$ por 10 minutos. O primer foi diluído com água destilada até a concentração de 5 pmoles $/ \mu \mathrm{L}$ para ser usado na reação de mutagênese.

\subsubsection{Reação de mutagênese.}

A mutagênese sítio dirigida permite alterar seqüências específicas de nucleotídeos (KUNKEL, 1985). Nessa reação os moldes sfDNAs contendo resíduos uracila hibridam com o primer de mutagênese cuja seqüência contém a mutação de interesse, a seqüência é polimerizada com o fragmento de Klenow da DNA polimerase I e as extremidades são ligadas com $T_{4}$ DNA ligase.

Para tanto, foram misturados e homogeneizados $5 \mu \mathrm{L}$ do DNA de fita simples, $1 \mu \mathrm{L}$ do primer fosforilado, $1 \mu \mathrm{L}$ do tampão de anelamento ( $\mathrm{NaCl}$ $500 \mathrm{mM}$, Tris $\mathrm{HCl} 100 \mathrm{mM} \mathrm{pH} 8,0 ; \mathrm{MgCl}_{2} 100 \mathrm{mM}$ e DTT $10 \mathrm{mM}$ ) e $3 \mu \mathrm{L}$ de água destilada. Esta reação foi incubada por $55^{\circ} \mathrm{C}$ por 5 minutos e resfriada por 10 minutos em temperatura ambiente.

O molde de DNA foi copiado após a adição dos seguintes reagentes: 4 $\mu \mathrm{L}$ de cada desoxinucleotídeo (dATP, dTTP, dCTP, dGTP) na concentração de 2,5 $\mathrm{mM}$ cada, $1 \mu \mathrm{L}$ do tampão ligase (Tris $\mathrm{HCl} 660 \mathrm{nM} \mathrm{pH} \mathrm{7,5;} \mathrm{MgCl}_{2} 50 \mathrm{mM}$; e 
DTT $50 \mathrm{mM}), 1 \mu \mathrm{L}$ de ATP $10 \mathrm{mM}, 5$ unidades do fragmento de Klenow da DNA polimerase I, $2 \mu \mathrm{L}$ de água destilada e 3,2 unidades da enzima $T_{4} D N A$ ligase. A mistura da reação foi incubada por 2 horas a temperatura ambiente. Adicionaram-se $30 \mu \mathrm{L}$ de água destilada, $25 \mu \mathrm{L}$ de acetato de amônio 7,5M e $150 \mu \mathrm{L}$ de etanol 95\%. Incubou-se 10 minutos em temperatura ambiente, centrifugou-se por $12.000 \mathrm{rpm}$ por 15 minutos. Após descartar o sobrenadante, lavou-se o precipitado de DNA com etanol 70\% e ressuspendeu em $10 \mu \mathrm{L}$ de água destilada.

Uma alíquota de $2 \mu \mathrm{L}$ foi utilizada para transformação de bactérias E.coli HB101 (dut $\left.t^{+} / u^{+} g^{+}\right)$eletrocompetentes. Nestas cepas dut a fita contendo os resíduos uracil (parental não mutado) é destruída, liberando uma simples com timina que contém a mutação de interesse.

Após a incubação por 2 horas no meio SOC, alíquotas das bactérias foram plaqueadas em LB $^{\text {AMP }}$ - ágar.

\subsubsection{Seleção do clone mutante pSecTag2-Igk-Giro.}

Após a mutagênese sítio dirigida, as colônias recombinante foram selecionadas da placa LB $^{\mathrm{AMP}}$-ágar e cultivadas em meio líquido $\mathrm{LB}^{\mathrm{AMP}}$ durante a noite com agitação e amplificadas por PCR (protocolo descrito no apêndice 9.1.7.3) com os primers GYR AS1 e T7. Como controle negativo foi utilizada uma alíquota de suspensão bacteriana transformada com 0 vetor parental pSecTag2-Giro antes da mutagênese.

A análise em gel de agarose 1,5\% identificou os clones positivos (pSecTag2-Igk-Giro), ou seja, aqueles cujos produtos de amplificação que apresentaram um tamanho aparente menor do que os controles (vetor parental pSecTag2-Giro antes da mutagênese), indicando a deleção da região esperada.

Esses clones positivos foram cultivados em meio líquido LB $^{\mathrm{AMP}}$ sendo realizada a extração do DNA plasmidial (kit WizardPlus S. V. Minipreps).

Os DNAs plasmidiais purificados foram digeridos e analisados para verificar a perda do sítio de restrição Not I, Eco RV e BamHI, presente no sítio de policlonagem do vetor parental pSecTag2-Giro, na região que se desejava deletar. Os clones positivos (pSecTag2-IgK-Giro) foram seqüenciados para a confirmação da mutagênese, para tanto foi necessário sintetizar o primer 
antisense GYR AS2, que corresponde a região de 257 a $274 \mathrm{pb}$ do clone da giroxina-símile (tabela 2).

\subsubsection{Obtenção do inserto IgK-Giro.}

O plasmídeo pSecTag2IgK-Giro $(42 \mu \mathrm{g})$ foi digerido com a enzima de restrição Xho I. Em seguida o DNA foi purificado por fenol/clorofórmio e precipitado de acordo com o protocolo descrito na apêndice 9.1.6, inativandose a enzima. O DNA foi ressuspenso em $80 \mu$ de água destilada.

Posteriormente $40 \mu \mathrm{g}$ do DNA linear foi tratado com o fragmento de Klenow da DNA polimerase I, juntamente com 0,05mM dos 4dNTPs obtendose extremidade de ponta cega. Após a inativação da enzima por calor, o DNA foi precipitado e ressuspenso em $16 \mu \mathrm{L}$ de água destilada.

Posteriormente $20 \mu \mathrm{g}$ de DNA foi digerido com a enzima de restrição Nhe I. Após este período inativou-se a enzima por calor.

Foi realizada uma eletroforese em gel de agarose $1 \%$ na qual se buscou obter dois fragmentos: o vetor e o inserto de $958 \mathrm{pb}$ correspondente ao IgK-Giro com extremidade coesiva Nhe I a $5^{\prime}$ e com extremidade cega a 3'para ligar no vetor $P E D$.

A banda IgK-Giro foi cortada do gel de agarose $1 \%$, e purificada (kit QIAquick Gel Extraction). Para confirmação do isolamento foi realizada uma análise em gel de agarose $1 \%$.

\subsubsection{Preparo do vetor pED para subclonagem do inserto IgK-Giro.}

o plasmídeo $(20 \mu \mathrm{g})$ foi digerido com a enzima de restrição SmaI. Posteriormente na mesma reação, acrescentou-se a enzima de restrição Xba I e incubou-se durante toda a noite sendo em seguida, inativada por calor.

A análise em gel de agarose $1 \%$ confirmou a completa digestão do vetor com as enzimas Xba I e Sma I tornando o vetor apto a receber o inserto IgK-Giro.

\subsubsection{Ligação do inserto IgK-Giro no vetor $\mathrm{PED}$ e seleção do clone pED-Giro.}

$O$ inserto Igk-Giro com extremidade $5^{\prime}$-Nhe I e $3^{\prime}$-cega foi subclonado no vetor linear de expressão pED com extremidade 5'-Xba I e 3'-Sma I. A extremidade coesiva Nhe I do inserto IgK-Giro é compatível com a 
extremidade Xba I do vetor pED. A extremidade $3^{\prime}$ cega do inserto IgK-Giro (digerido com Xho I e tratado com Klenow) é compativel com a extremidade 3' cega do vetor PED (digerido com Sma I).

Após a ligação utilizando-se a enzima T4 DNA ligase, foi realizada a transformação em E. coli TOP 10 (bactéria quimicamente competente). Após o crescimento das colônias recombinantes em placas LB $^{\text {AMP }}$ - Agar e seleção dos clones por tamanho de plasmídeo recombinante (protocolo descrito no apêndice 9.1.7.2), a amostra do plasmídeo que apresentou uma migração aparente maior do que o tamanho do vetor vazio (não recombinante) é provavelmente o pED-Giro.

A construção deste vetor foi confirmada por PCR (protocolo descrito no apêndice 9.1.7.3) com os primers GYR SE e GYR AS1 tendo como amostras uma alíquota da suspensão bacteriana contendo o plasmídeo recombinante e como controles negativos um clone não recombinante e o vetor vazio não recombinante. Essas amostras foram analisadas em gel de agarose 1,5\%.

O clone positivo $\mathrm{PED}$-Giro foi cultivado em meio $\mathrm{LB}^{\mathrm{AMP}}$ durante a noite com agitação e realizada a extração do DNA plasmidial (kit WizardPlus S. V. Minipreps).

\subsection{Expressão do vetor PED-Giro em células CHO DXB11 dhfr'.}

\subsubsection{Seleção e amplificação dos clones.}

As células CHO DXB11 dhfr foram cultivadas em placas de $50 \mathrm{~cm}^{2} \mathrm{com}$ o meio de cultura essencial mínimo $\alpha$-MEM suplementado com $50 \mathrm{U} / \mathrm{mL}$ de penicilina, $50 \mu \mathrm{g} / \mathrm{mL}$ de estreptomicina, $1,25 \mu \mathrm{g} / \mathrm{mL}$ de anfotericina $B$ e $2 \mathrm{mM}$ de L-glutamina e $10 \%$ de soro fetal bovino e quando estas células atingiram a semi-confluência, o plasmídeo pED-Giro foi transfectado pelo método de fosfato de cálcio (GRAHAM \& VAN DER EB,1973), passando a se integrar no genoma da célula CHO-DXB11.

Os clones celulares transfectados foram isolados e cultivados em uma placa $4 \mathrm{~cm}^{2}$. A seleção dos clones transfectados foi realizada em meio seletivo $\alpha$-MEM na ausência de ribonucleosídeo e desoxiribonucleosídeo com as mesmas concentrações de penincilina, estreptomicina, anfotericina B e Lglutamina descritos anteriormente, suplementado com $10 \%$ de soro fetal bovino dialisado. Em torno de 2-3 semanas, alguns clones dhfr positivos, foram submetidos a incrementos graduais de concentrações de metotrexato 
(MTX:5, 20, 80, 320 e 1280nM) e em cada etapa de amplificação alíquotas dos clones foram congelados em nitrogênio líquido.

Os diferentes momentos do cultivo celular foram registrados utilizando-se o microscópio óptico com aumento de 400x.

\subsection{2- Deteç̧ão da proteína recombinante expressa pelo vetor pED- Giro em células CHO DXB11 por SDS-PAGE e western blot.}

As amostras do extrato celular bruto de células CHO-DXB11 transfectadas e não transfectadas com o plasmídeo pED-Giro e o meio de cultura em que cresceram esses clones em diversas concentrações de MTX foram analisadas por SDS-PAGE e western blot (protocolos descritos respectivamente nos apêndices 9.6.1 e 9.6.2).

\subsubsection{Detecção do vetor pED-Giro integrado ao genoma da célula CHO- DXB11.}

Para detectar a presença do vetor pED-Giro integrado no genoma da célula CHO-DXB11 foi cultivado um clone transfectado sem amplificação, nas condições descritas anteriormente, até atingir a semi-confluência. Como controle negativo foi utilizado a célula não transfectada (CHO-DXB11 dhfř) e como controle positivo o plasmídeo pED-Giro.

As células foram tripsinizadas e transferidas para um microtubo de $2 \mathrm{~mL}$ e contrifugadas por 5 minutos a 1500rpm. O precipitado foi lavado 2 vezes com $500 \mu \mathrm{L}$ de PBS. Após esta etapa, para se preparar o DNA genômico as células foram ressuspendidas em $500 \mu \mathrm{L}$ do tampão $K$ (1x do tampão de PCR:20mM Tris- $\mathrm{HCl}$ pH 8,4 e $50 \mathrm{mM} \mathrm{KCl}, 0,5 \%$ de Tween-20 e $100 \mu \mathrm{g} / \mathrm{ml}$ de proteinase $\mathrm{K}$ ) e incubado a $55^{\circ} \mathrm{C}$ por $1 \mathrm{~h}$. Inativou-se a proteinase $\mathrm{K}$ a $95^{\circ} \mathrm{C}$ por 10 minutos (KAWASAKI, 1990).

O PCR foi realizado com os primers IgK SE e DHFR AS (figura 13-A), IgK SE e GYR AS1 (figura 13-B) e DHFR SE/AS (figura 13-C) e $4 \mu \mathrm{L}$ do lisado celular. Como um controle positivo da reação foi utilizado $1 \mu \mathrm{L}$ do plasmídeo pED-Giro e como controle negativo água destilada. As condições de reação foram as mesmas descritas no apêndice 9.1.5. As amostras foram analisadas em gel de agarose $1.0 \%$. 


\subsubsection{Detecção do mRNA expresso pela célula CHO-DXB11 x pED-Giro.}

Com a finalidade de verificar a presença do mRNA da giroxina B2.1 foram realizados ensaios de RT-PCR (reverse transcriptase-polymerase chain reaction), com alguns clones transfectados com o plasmídeo pED-Giro na ausência e na presença de duas concentrações de MTX (20nM e 320nM). Como controles foram utilizadas as células não transformadas $\mathrm{CHO}-\mathrm{K} 1 \mathrm{dhfr}^{+}$ que deve dar bandas quando amplificados com primers específicos para DHFR mas não quando amplificados com primers específicos para giroxina. E as células CHO-DXB11 dhfr que não deve dar sinal em ambos os casos.

Os clones utilizados foram: clones 4, 6, 8 sem amplificação com MTX, o clone 4 amplificado com 20nM de MTX e o clone 6 amplificado com 320nM de MTX. Os pares primers GYR SE/DHFR AS (figura 14-A) e IgK SE/DHFR AS (figura 14-D) foram utilizados com a finalidade de verificar se o mRNA da fusão entre a giroxina e o DHFR se encontra na forma dicitrônica, os pares primers GYR SE/AS (figura 14-C) e IgK SE/GYR AS (figura 14-F) foram utilizados para verificar se o mRNA giroxina foi expresso separado do mRNA dhfr que é detectado pelo par de primers DHFRSE/AS (figura 14-B ou E).

Os clones celulares foram cultivados em placas de $40 \mathrm{~cm}^{2}$ no meio de cultura $\alpha$-MEM na ausência de ribonucleosídeo e desoxiribonucleosídeo até atingirem a semi-confluência. As células CHO-K1 dhfr ${ }^{+}$e CHO DXB11 dhfr foram cultivadas em meio de cultura $\alpha$-MEM. As condições de cultivo foram descritas no subitem 3.8.1-Seleção e amplificação dos clones (página 33). Os clones celulares e as células controle negativo foram submetidos à extração do RNA e precipitação segundo protocolo do reagente Trizol.

O RNA foi ressuspenso em $80 \mu$ l de água. As amostras foram analisadas em gel de agarose $1 \%$ e quantificadas no espectrofotômetro em uma absorbância de $260 \mathrm{~nm}$.

Para a síntese de primeira fita de CDNA por RT-PCR foi utilizado o kit SuperScript III (Invitrogen) seguindo-se o protocolo do fabricante. Foram realizados seis ensaios de $R T-P C R$ denominados de $A, B, C, D, E$ e $F$ sendo que o esquema das reações estão mostradas na figura 14.

Nos ensaios A, B e C foram utilizados $3,5 \mu \mathrm{g}$ de RNA total dos clones 4 e 8 e da célula CHO-K1 $\mathrm{dhfr}^{+}$(controle negativo) e nos ensaios $\mathrm{D}, \mathrm{E}$ e $\mathrm{F}$ foram utilizados $8 \mu \mathrm{L}$ de RNA total isolados dos clones 4 e 6 na ausência de MTX, 
clone 4 com 20nM MTX, clone 6 com 320nM de MTX e da célula CHO-DXB11 dhfr' (controle negativo).

Para realizar a síntese de primeira fita de cDNA foram utilizados $1 \mu \mathrm{L}$ do primer antisense, os RNAs isolados dos clones e das células controles negativos CHO-K1 dhfr ${ }^{+}$e CHO-DXB11 dhfr, $1 \mu \mathrm{L}$ de $10 \mathrm{mM}$ DNTPs e água tratada com DEPC ( $0.1 \%$ Diethyl Pyrocarbonate em água) para um volume final de $10 \mu \mathrm{L}$. Após incubar $65^{\circ} \mathrm{C}$ por 5 minutos, foram adicionados $2 \mu \mathrm{L}$ do 10 $x$ tampão de RT-PCR (200 mM Tris-HCl pH 8,4, $500 \mathrm{mM} \mathrm{KCl}$ ); $4 \mu \mathrm{L}$ de $25 \mathrm{mM}$ $\mathrm{MgCl}_{2} ; 2 \mu \mathrm{L}$ de $0,1 \mathrm{M} \mathrm{DTT} ; 1 \mu \mathrm{L}$ de inibidor de RNAse (RNAse Out) e $1 \mu \mathrm{L}$ da enzima transcriptase reversa SuperScript III, com exceção do controle, obtendo-se um volume final de $20 \mu \mathrm{L}$. As amostras foram incubadas a $50^{\circ} \mathrm{C}$ por $1 \mathrm{~h}$, inativadas a $85^{\circ} \mathrm{C}$ por 5 minutos e mantidas em gelo.

Para a síntese da segunda fita de CDNA, as amostras foram amplificadas por PCR com os primers GYR SE/DHFR AS (figura 14-A), DHFR SE/AS (figura 14-B), GYR SE/AS1 (figura 14-C), IgkSE/DHFR AS (figura 14D), DHFR SE/AS (figura 14-E) e Igk SE/GYR AS1 (figura 14-F). Como controle da reação foi utilizada a água.

O PCR consiste de 40 ciclos de $94^{\circ} \mathrm{C}$ por 3 minutos, $94^{\circ} \mathrm{C}$ por 45 segundos, para denaturar o DNA molde, $56^{\circ} \mathrm{C}$ por 45 segundos para 0 anelamento dos primers, $72^{\circ} \mathrm{C}$ por 1 minuto para polimerização. Ao final dos ciclos de polimerização a reação foi finalizada por um ciclo de extensão a $72^{\circ} \mathrm{C}$ por 7 minutos e mantidas a $4^{\circ} \mathrm{C}$ até a análise em gel de agarose $1,0 \%$ com o marcador $250 \mathrm{pb}$ DNA ladder.

\subsection{Expressão transiente do vetor pED-Giro em células cos-7.}

As células COS-7 foram transfectadas com os plasmídeos pED-Giro e pSecTag-IgK-Giro (após a mutagênese) com a finalidade de verificar a funcionalidade desses vetores.

As células cos-7 foram cultivadas em garrafa de cultura de $75 \mathrm{~cm}^{2}$ com $10 \mathrm{~mL}$ de meio D-MEM contendo $50 \mathrm{U} / \mathrm{mL}$ de penicilina, $50 \mu \mathrm{g} / \mathrm{mL}$ de estreptomicina na presença de antibiótico e com $10 \%$ de soro fetal bovino, até atingirem a semi-confluência. Em seguida foram tripsinizadas e contadas em uma câmara de Malassez e distribuídas em uma placa de 6 poços ( 450.000 células por poço, equivalente a $10 \mathrm{~cm}^{2}$ ) contendo $5 \mathrm{~mL}$ de meio em cada poço. 
Após 24h, quando as células atingiram a semi-confluência, foram realizadas as transfecções em duplicatas utilizando-se $4 \mu \mathrm{g}$ dos plasmídeos pED-Giro, pSecTag-IgK-Giro e como controle positivo o plasmídeo pEGFP-N1. Este plasmídeo expressa a proteína fluorescente GFP (obtida da medusa bioluminescente- Aequora victoria) sendo detectada em $395 \mathrm{~nm}$. Como controle negativo foram utilizados as células COS-7 não transfectadas. As transfeç̧ões foram realizadas segundo o protocolo do reagente Lipofectamine.

As células COS-7 transfectadas com os plasmídeos pED-Giro e pEGFPN1 foram fotografadas no microscópio utilizando-se filtro fluorescente ultravioleta, com o aumento de 400x.

Os meios de cultura em que cresceram as células $\cos -7, \cos -7$ transfectadas com os plasmídeos pED-Giro e pSecTag-IgK-Giro em 24 e $48 \mathrm{~h}$ foram coletados ( $10 \mathrm{~mL}$ de meio) e as células foram coletadas por tripsinização após $72 \mathrm{~h}$ da transfeç̧ão (conforme descrito no subitem 3.8.2 - Deteç̧ão do vetor pED-Giro integrado ao genoma da célula-página 34). Após o precipitado celular ser lavado com PBS, os materiais foram congelados a $-20^{\circ} \mathrm{C}$. As amostras do meio de cultura, precipitado celular e o sobrenadante do lisado foram analisadas em SDS-PAGE e western blot com a finalidade de se detectar a presença da proteina recombinante. Os protocolos das análises dos SDSPAGE e western Blot se encontram respectivamente nos apêndices 9.6.1 e 9.6.2.

Em um segundo momento, o plasmídeo pED-Giro foi transfectado em duplicata uma escala maior $(20 \mu \mathrm{g}$ de plasmídeo para 2.000 .000 células, em uma placa de $50 \mathrm{~cm}^{2}$ contendo $10 \mathrm{~mL}$ de meio) para se obter a giroxina recombinante em uma quantidade suficiente para realizar os ensaios de caracterização. Os meios de cultura em que cresceram as células $(20 \mathrm{~mL})$ foram coletados $24 \mathrm{~h}$ e $48 \mathrm{~h}$ após a transfecção com o plasmídeo pED-Giro e congelados. Após $72 \mathrm{~h}$ as células foram coletadas e o precipitado celular foi lavado 3 vezes com PBS.

Nesta nova preparação, o precipitado celular foi ressuspenso em $2 \mathrm{~mL}$ de tampão $50 \mathrm{mM}$ Tris $\mathrm{HCl}$ pH 9,0 contendo $400 \mathrm{mM} \mathrm{NaCl}$ e sonicado 2 vezes com 2 pulsos de 5 segundos cada, com amplitude 70. Esta amostra foi centrifugada e separado o sobrenadante solúvel correspondente ao lisado celular e o precipitado. Ambos foram analisados por SDS-PAGE e western blot. 
3.9.1 Purificação do produto recombinante expresso pelo vetor PEDGiro em células cos-7.

Para separação da proteina recombinante do meio de cultura e/ou dos lisados celulares, foi utilizada a resina de afinidade Benzamidina Sepharose 4B em sistema "in batch". Esta resina possui como ligante $p$-aminobenzamidina (pABA) com a capacidade de ligar até $35 \mathrm{mg}$ tripsina/mL. Inicialmente, a resina foi ativada com 3 lavagens alternadas de tampão Tris $\mathrm{HCl} 100 \mathrm{mM} \mathrm{pH} 8,5$ contendo $400 \mathrm{mM} \mathrm{NaCl}$ e Acetato de Sódio $100 \mathrm{mM} \mathrm{pH} \mathrm{4,5} \mathrm{contendo} 500 \mathrm{mM}$ $\mathrm{NaCl}$.

A adsorção do produto recombinante foi realizada a $4{ }^{\circ} \mathrm{C}$, com agitação suave durante a noite, com um volume fixo de $100 \mu \mathrm{L}$ de resina ativada e volumes variáveis das seguintes amostras: meio de cultura controle negativo, meio de cultura $24 \mathrm{~h}$ após a transfecção da célula COS-7 $\times$ pED-Giro, meio de cultura $48 \mathrm{~h}$ após a transfeç̧ão da célula COS-7 x pED-Giro, o sobrenadante do lisado das células COS-7 controle negativo e das células COS-7xpED-Giro.

No dia seguinte as amostras que ficaram incubando com a resina foram centrifugadas a 700 rpm, 5 minutos, $4^{\circ} \mathrm{C}$. O sobrenadante foi separado para análises posteriores e o precipitado com a resina foi lavado 3 vezes com o tampão $50 \mathrm{mM}$ Tris $\mathrm{HCl}$ pH 9,0 contendo $400 \mathrm{mM} \mathrm{NaCl}$, sendo em seguida eluída com tampão Acetato de Amônio $100 \mathrm{mM}$ pH 5,0.

As amostras foram separadas em alíquotas e secas durante a noite no Speed Vack. Estas alíquotas das diferentes amostras foram analisadas por dosagem de proteínas, SDS-PAGE, Western blot e atividade enzimática.

3.9.1.1. Dosagem de proteína recombinante expressa pelo vetor pEDGiro em células cos-7.

A determinação do conteúdo protéico das amostras permitiu avaliar o rendimento da expressão e purificação da proteína recombinante assim como as comparações nos ensaios de caracterização.

O método utilizado foi o descrito por BRADFORD, 1976. Este método se baseia na capacidade do corante Coomassie Blue R-250 de se ligar as proteínas, em meio altamente ácido, resultando na modificação proporcional da cor, detectável em $595 \mathrm{~nm}$.

Para a curva padrão utilizou-se a albumina bovina sérica (SAB) $1 \mathrm{mg} / \mathrm{ml}$ em solução salina $(0,9 \% \mathrm{NaCl})$ em diferentes diluições: $2,5 \mu \mathrm{l}(2,5 \mu \mathrm{g})$, 
$5 \mu \mathrm{l}(5 \mu \mathrm{g}), 10 \mu \mathrm{l}(10 \mu \mathrm{g}), 12,5 \mu \mathrm{l}(12,5 \mu \mathrm{g}), 15 \mu \mathrm{l}(15 \mu \mathrm{g}), 17,5 \mu \mathrm{l}(17,5 \mu \mathrm{g})$ e $20 \mu \mathrm{l}$ $(20 \mu \mathrm{g})$. Em seguida o volume foi completado para $100 \mu \mathrm{l}$ com a solução salina e adicionados $1 \mathrm{~mL}$ do reagente de Bradford.

As amostras foram todas analisadas nas mesmas condições. Após 10 minutos, à temperatura ambiente, foi medida a densidade ótica, em espectrofotômetro. Todos os pontos foram duplicatas e os dados da curva padrão foram ajustados com o programa Graph Pad Prims, por regressão linear com a equação $y=a x+b$ para calcular a concentração proteíca das amostras, sendo $(y)$ a densidade ótica, $(x)$ a concentração proteíca, (a) o coeficiente angular da reta e (b) o intercepto da reta.

3.9.1.2. Detecção da proteína recombinante expressa pelo vetor pEDGiro em células coS-7 por SDS-PAGE e western blot.

Os ensaios para deteç̧ão da proteína recombinante foram realizadas por eletroforese em gel de poliacrilamida e Western blot.

Foram coletadas amostras de culturas de células COS-7 não transfectadas e transfectadas com o plasmídeo pED-Giro, após serem tripsinizadas, centrifugadas e lavadas com PBS. As células foram sonicadas para preparo das amostras do sobrenadante e do precipitado do lisado celular. O sobrenadante do lisado e os meios de cultura em que cresceram as células por $24 \mathrm{~h}$ e $48 \mathrm{~h}$ após a transfecção com o pED-Giro foram utilizados para preparar amostras antes e após a purificação por afinidade em resina de afinidade benzamidina sepharose (vide item 3.9.1-Purificação do produto recombinante expresso pelo vetor pED-Giro em células COS-7).

Como controles foram utilizados $3 \mu \mathrm{g}$ de tripsina (controle negativo) e $3 \mu \mathrm{g}$ de giroxina purificada do veneno de C.d.terrificus (controle positivo).

\subsubsection{Ensaio de atividade enzimática da giroxina recombinante purificada por benzamidina sepharose.}

Com a finalidade de se verificar se o produto recombinante do clone B2.1 giroxina está sendo expressa pelo vetor pED-Giro na forma ativa, foi realizado o teste de atividade esterásica. Neste ensaio foi utilizado o método descrito por NOLAN et al, 1976. As amostras da proteína recombinante purificada foram dissolvidas em tampão Tris $\mathrm{HCl} 80 \mathrm{mM} \mathrm{pH} \mathrm{8,1} \mathrm{contendo} 20 \mathrm{mM}$ de $\mathrm{CaCl}_{2}$. Como padrão foram utilizados $100 \mathrm{ng}$ e $1 \mu \mathrm{g}$ de tripsina de pâncreas 
de porco $(1 \mathrm{mg} / \mathrm{mL})$ dissolvidos em $0,001 \mathrm{~N}$ de $\mathrm{HCl}$ e giroxina purificada do veneno da cascavel Crotalus durissus terrificus na concentração de $100 \mathrm{ng}$ e $2 \mu \mathrm{g}$ dissolvido em tampão $40 \mathrm{mM}$ Tris $\mathrm{HCl}$ pH 7,4.

Na reação foram incubados $1 \mathrm{~mL}$ do substrato TAME com $2 \mu \mathrm{g}$ de cada amostra e medida a densidade ótica em $247 \mathrm{~nm}$ após 5 minutos de reação, à temperatura ambiente. 


\subsection{Clonagem da toxina madura.}

O produto da reação de PCR amplificando uma alíquota da biblioteca com os primers GYR SE (específico para a região $\mathrm{N}$-terminal da giroxina) e T7 segundo esquema mostrado na figura 9, resultou em 3 bandas, com tamanhos aproximados de $1200 \mathrm{pb}, 900 \mathrm{pb}$, e $550 \mathrm{pb}$ sendo denominadas respectivamente de bandas B2, B1 e BO (figura 15). O produto da reação foi diretamente clonada no vetor PCR-2.1TOPO e bactérias $E$. coli TOP10 (quimicamente competentes) foram transformadas e selecionadas em meio LB $^{\text {AMP }}$-Agar com XGal/IPTG segundo esquema mostrado na figura 38.

Os clones obtidos ( 1 a 9 ) com tamanho aparente do produto de amplificação por PCR da biblioteca (bandas B2, B1 e B0) foram isolados pelo protocolo 9.1.7.3 (apêndice) - seleção dos clones por PCR de colônias (figura 16). Foram numerados de acordo com o tamanho da banda da seguinte forma: clone B1.1; clone B0.1; clone B0.2; clone B2.1; clone B0.3; clone $B 0.4$; clone B1.2; clone B1.3; Clone B1.4. Cada clone isolado foi seqüenciado nas fitas direta e reversa.

\subsubsection{Análises dos clones correspondentes às bandas B0, B1 e B2.}

$A$ comparação das seqüências de cDNA e proteinas dos clones $B 2.1$, $\mathrm{B} 1.1, \mathrm{~B} 1.2, \mathrm{~B} 1.3, \mathrm{~B} 1.4, \mathrm{~B} 0.1, \mathrm{~B} 0.2, \mathrm{~B} 0.3, \mathrm{~B} 0.4$ com bancos de dados, permitiu verificar que somente o clone $B 2.1$ é uma isoforma completa de giroxina. Os clones B1.1, B1.2, B1.3 e B1.4 apresentaram seqüências parciais de serino proteases e os clones B0.1, B0.2 e B0.3 não apresentaram similaridade com toxinas de serpentes. Os valores obtidos pela análise de Phred da seqüência do clone B2.1 se encontra na tabela 6 e foi na média superior a $30 \%$ demonstrando a alta qualidade da seqüência.

Nas tabelas 7 e 8 são mostradas as cinco sequências de nucleotídeos e proteínas de serino proteases do veneno de serpentes mais similares com o clone B2.1.

O alinhamento do clone B2.1-giroxina com seqüências do $\mathrm{N}$-terminal da giroxina purificada do veneno da Crotalus durissus terrificus (figura 17) 
evidenciou diferenças entre as seqüências $\mathrm{N}$-terminais, sendo o clone B2.1 denominado de giroxina-símile.

A seqüência do clone B2.1 foi depositada como "gyroxin-like" no Banco Internacional de Dados de seqüências de nucleotídeos GenBank, sob o número de acesso AY954040 Crotalus durissus terrificus gyroxin-like B2.1 precursor, mRNA, partial cds (coding domain sequence) (figura 18).

\subsection{2- Análise do clone B2.1}

A comparação dos éxons do cDNA do clone B2.1 com o gene da batroxobin apresentado esquematicamente na figura 27 permitiu observar a presença de 4 possiveis éxons (também identificado figura 18): éxon 2 (1$137 \mathrm{pb})$, éxon 3 (138-379pb), éxon 4 (389-548pb) e éxon 5 (549-881pb). A tríade catalítica se encontra nos éxons: 2 (H43), 3 (D88) e 5 (S184). O éxon 1 corresponde à região do 5 'UTR e a região codificante para o peptídeo sinal e pro-peptídeo, que está ausente neste clone, é decorrente da estratégia de clonagem. Lembrando, este clone foi amplificado utilizando-se o primer sense GYR SE que é complementar aos 24 primeiros nucleotídeos da região que codifica o início do $\mathrm{N}$-terminal da giroxina de Crotalus durissus terrificus e o primer antisense T7 que é complementar a uma região flanqueadora do sítio de clonagem do vetor $\lambda$-ZAP-XR da biblioteca. A definição do primer GYR SE se encontra na figura 8 e a região de hibridação desses primers (GYR SE e T7) está representada na figura 9.

O cDNA se subdivide em uma região de $714 \mathrm{pb}$ que codifca para uma toxina madura de 238 aminoácidos e uma região $3^{\prime}$ UTR curta de $181 \mathrm{pb}$. O stop códon se encontra na posição $715 \mathrm{pb}$ e o sinal de poliadenilação na posição $857 \mathrm{pb}$. A cauda de poli $\mathrm{A}$ está presente. O sítio potencial de $\mathrm{N}$ glicosilação apresenta o seguinte consenso: Asn-Xaa-Ser/Thr, na qual Xaa pode ser qualquer aminoácido exceto prolina. Na giroxina-símile, o sítio potencial de $\mathrm{N}$-glicosilação encontrado foi na asparagina 81 e o de $\mathrm{O}$ glicosilação na treonina 127. Este clone também permite predizer por homologia a presença de 6 pontes dissulfetos entre as seguintes cisteínas:7141, 28-44, 78-236, 120-190, 152-169, 180-205 (figura 34).

A seqüência de CDNA e de aminoácidos de SVSPs que apresentaram maior homologia com o clone B2.1 foram respectivamente: Tlg2b de Trimeresurus gramineus e bilineobin de Agkistrodon bilineatus. 
A SVSP mais homóloga com a parte correspondente da toxina madura foi bilineobin de Agkistrodon bilineatus (tabela 24).

\subsection{Clonagem de isoformas de serino proteases similares a giroxina.}

\subsubsection{Obtenção dos clones pCR2.1 TOPO-GPSs.}

Com base na seqüência do clone B2.1 foi possível sintetizar o primer antisense GYR AS1 que com o primer sense T3 permitiu reamplificar a biblioteca e clonar seqüências de giroxina contendo a região a $5^{\prime}$ segundo o esquema mostrado na figura 10. A seqüência de complementaridade do primer GYR AS1 é mostrada na figura 29.

A análise do produto de PCR em gel de agarose 1,5\% correspondente aos clones GPSs (giroxina peptídeo sinal), resultou em três bandas similares as mostradas na figura 15, sendo que a primeira banda de $1200 \mathrm{pb}$ foi excisada do gel, purificada e clonada no vetor pCR2.1 TOPO, pois as bandas de menor tamanho podem representar seqüências degradadas presentes na biblioteca (dados não mostrados).

Após a transformação da ligação (vetor-inserto) em bactéria quimicamente competente e seleção das colônias recombinantes pelo protocolo descrito no apêndice 9.1.7.3, foram obtidas 4 colônias sendo denominadas GPS:2, GPS:3, GPS:4 e GPS:5. Estes clones foram totalmente seqüenciados e as análises em banco de dados revelaram similaridades com serino proteases do veneno de serpentes. Os valores obtidos pela análise de Phred das seqüências dos clones GPSs se encontram na tabela 6 sendo que as bases apresentaram uma qualidade superior a $30 \%$ evidenciando a alta qualidade dos seqüenciamentos.

\subsubsection{Análises das seqüências de CDNA e de proteína dos clones GPSs.}

Os clones GPS:2 e GPS:5 assim como os GPS:3 e GPS:4 representam clones com a mesma seqüência, passando a serem denominados GPS:2e5 e GPS:3e4. A organização do cDNA do clone GPS:2e5 está mostrada na figura 19 e a do clone GPS:3e4 está mostrada na figura 20. 
Estes clones possuem as regiões correspondentes à região não traduzida 5'UTR, à região codificante para o peptídeo sinal, à região codificante para o pré-peptídeo e à região codificante para a toxina madura. A correspondência dos cDNAs em comparação com os éxons do gene da batroxobin dos clones GPS:2e5 e GPS:3e4 está mostrada na figura 27 e na tabela 21. Assim sendo, estes clones contêm o cDNA correspondente a todos os cinco éxons do gene da batroxobin, sendo a região correspondente ao éxon 5 está presente apenas parcialmente faltando toda a $3^{\prime}$ UTR, pois foi limitada pelo primer GYR AS1. Estes clones não apresentam stop códon pois o primer GYR AS1 foi baseada na seqüência C-terminal do clone B2.1 giroxina-símile imediatamente antes do stop códon. O esquema de hibridação do primer GYR AS se encontra na figura 10.

\subsubsection{2- Análise do clone GPS:2e5.}

Podemos observar na figura 19 a presença de 5 possíveis éxons mostradas na figura 27 e na tabela 21: éxon 1 (31-264pb), éxon 2 (265$421 \mathrm{pb})$, éxon 3 (442-663pb), éxon 4 (664-832pb) e éxon 5 (833-998pb). A tríade catalítica se encontra nos éxons: 2 (H67), 3 (D112) e 5 (S208). As análises do clone GPS:2e5 permitiram identificar o sítio potencial de $\mathrm{N}$ glicosilação na asparagina 105 e o sítio potencial de O-glicosilação na treonina 151. O cDNA se subdivide em uma região 5 'UTR de $212 \mathrm{pb}$, uma região de $54 \mathrm{pb}$ que codifica para o peptídeo sinal de 18 aminoácidos, uma região de $18 \mathrm{pb}$ que codifica para o pró-peptídeo de 6 aminoácidos e uma região de $714 \mathrm{pb}$ que codifica para a toxina madura de 238 aminoácidos. A região de Kozak representado pelo códon $-3(G)$ se encontra na posição $210 \mathrm{pb}$ e o códon de início da tradução se encontra na posição $213 \mathrm{pb}$. As 6 pontes dissulfetos preditas seriam entre as cisteínas 7-141, 28-44, 78-236, 120-190, 152-169, 180-205 (figura 34).

Nas tabelas 9 e 10 são mostradas as cinco seqüências de cDNA e precursores de serino proteases de venenos de serpentes mais similares a este clone. A seqüência de cDNA e o precursor que apresentaram maior homologia com este clone GPS:2e5 foram respectivamente: calobin de Agkistrodon ussuriensis e stejnobin de Trimeresurus stejnegeri.

A SVSP mais homóloga com a parte correspondente da toxina madura foi bilineobin de Agkistrodon bilineatus (tabela 24). 


\subsubsection{3-Análise do clone GPS:3e4.}

Com relação à organização do cDNA deste clone podemos observar na figura 20 a presença de 5 possiveis éxons mostradas na figura 27 e na tabela 21: éxon 1 (1-239pb), éxon 2 (240-396pb), éxon 3 (397-600pb), éxon 4 (661-807pb) e éxon 5 (808-976pb). A tríade catalítica se encontram nos éxons: 2 (H 67), 3 (D 112) e 5 (S 208). Os sítios potenciais de $\mathrm{N}$-glicosilação encontrados neste clone foram nas asparaginas 105 e 255 e o sítio potencial de O-glicosilação na treonina 152. O cDNA se subdivide em uma região 5 'UTR de $187 \mathrm{pb}$, uma região de $54 \mathrm{pb}$ que codifica para o peptídeo sinal de 18 aminoácidos, uma região de $18 \mathrm{pb}$ que codifica para o pró-peptídeo de 6 aminoácidos e uma região de $714 \mathrm{pb}$ que codifica para a toxina madura de 238 aminoácidos. A região de Kozak representado pelo códon $-3(G)$ se encontra na posição $185 \mathrm{pb}$ e o códon de início da tradução se encontra na posição $188 \mathrm{pb}$. As 6 pontes dissulfetos preditas por similaridades seriam entre as cisteínas 7-141, 28-44, 78-236, 120-190, 152-169, 180-205 (figura 34).

Da mesma forma que para o clone GPS:2e5 as cinco seqüências de CDNA e proteínas de SVSPs com maior similaridade com o clone GPS:3e4, foram relacionadas nas tabelas 11 e 12 . A seqüência de CDNA e o precursor que apresentaram maior homologia com este clone foram respectivamente: calobin de Agkistrodon ussuriensis e stejnobin de Trimeresurus stejnegeri.

A SVSP mais homóloga com a parte correspondente da toxina madura foi stejnobin de Trimeresurus stejnegeri (tabela 24).

O alinhamento da região do peptídeo sinal, pré-peptídeo e início da toxina madura dos clones B2.1, GPS:2e5 e GPS:3e4 com outras seqüências de precursores de serino proteases mostra seqüências de nucleotídeos correspondentes ao início da região codificante a $5^{\circ}$ (figura 21). Permite observar que a alta conservação da região do peptídeo sinal e pré-peptídeo dos clones GPS:2e5 e GPS:3e4 também ocorre com outras seqüências de precursores de serino proteases como as enzimas de cascavéis norte americanas ou seqüências de enzimas de serpentes evolutivamente distantes da cascavel sul americana, tais como as serpentes asiáticas do gênero Trimeresurus ou seqüências de serino proteases pertencentes a serpentes de outros gêneros tais como as dos gênero Bothrops ou Agkistrodon. 


\subsubsection{Obtenção dos clones PCR2.1 TOPO-PST7s.}

Conhecendo-se a seqüência do clone B2.1 e as seqüências dos clones GPS e tendo em vista a elevada conservação do peptídeo sinal, foi possível sintetizar um primer peptídeo sinal P.S sense mostrado na figura 21 que foi utilizado com o primer antisense $\mathrm{T} 7$ para novamente reamplificar a biblioteca de acordo com o esquema da figura 11, obtendo-se as seqüências precursoras completas que denominamos clones PST7. Esses clones contêm a região codificante para o peptídeo sinal, para a toxina madura e a região 3 'UTR. A região de hibridação do primer peptídeo sinal P.S sense pode ser vista na figura 29.

O produto de PCR foi analisado em gel de agarose $1,5 \%$ resultando novamente em três bandas sendo que a primeira com tamanho aproximado de $1600 \mathrm{pb}$ e maior intensidade, foi excisada do gel e purificada (figura 22).

As bandas de menor tamanho podem representar seqüências parciais presentes na biblioteca tal como aconteceu nos clones B1 e B0 mostrados na figura 15.

Após a clonagem no vetor PCR2.1 TOPO e-seleção das colônias recombinantes pelo protocolo descrito no apêndice 9.1.7.3, obteve-se 5 clones sendo denominados PST7:3, PST7:4, PST7:5, PST7:7 e PST7:8. As análises desses clones com seqüências depositadas em banco de dados, revelaram similaridades com serino proteases de venenos de serpentes.

Os valores obtidos pela análise de Phred das seqüências dos clones PST7s se encontram na tabela 6 , sendo que na médias as bases apresentaram uma qualidade superior a $30 \%$ evidenciando a alta qualidade dos seqüenciamentos.

Podemos observar que estes clones apresentam a região codificante para o peptídeo sinal, para o pré-peptídeo, para a toxina madura e a região não traduzida $3^{\prime}$ UTR. A correspondência dos cDNAs em comparação com os éxons do gene da batroxobin dos clones PST7s está mostrada na figura 27 e na tabela 21. Assim sendo, estes clones contêm o cDNA correspondente a todos os cinco éxons do gene da batroxobin, sendo a região correspondente ao éxon 1 apenas parcial, pois é limitada pelo primer peptídeo sinal PS sense, faltando toda a 5'UTR. 


\subsubsection{Análises das sequências de cDNA e de proteínas dos clones} PST7s.

As análises das seqüências dos clones PST7:3, PST7:4, PST7:5, PST7:7 e PST7:8 permitiu concluir que os clones PST7:7 e PST7:8 são a mesma seqüência, passando as ser denominado de clone PST7:7e8.

\subsubsection{2- Análise do clone PST7:3.}

Com relação a organização do cDNA deste clone (figura 23), podemos observar a presença de 5 regiões correspondentes aos éxons do gene de batroxobin mostradas na figura 27 e na tabela 21: éxon 1 (1-52pb), éxon 2 (53-209pb), éxon 3 (210-451pb), éxon 4 (452-620pb) e éxon 5 (621-1401). A tríade catalítica se encontra nos éxons: 2 (H67), 3 (D112) e 5 (S208). O sítio potencial de $\mathrm{N}$-glicosilação encontrado neste clone foi asparagina 105 e o sítio potencial de O-glicosilação na treonina 152.

O cDNA se subdivide em uma região de $54 \mathrm{pb}$ que codifica para o peptídeo sinal de 18 aminoácidos, uma região de $18 \mathrm{pb}$ que codifica para o pró-peptídeo de 6 aminoácidos, uma região de $714 \mathrm{pb}$ que codifica para a toxina madura de 238 aminoácidos e uma região 3 'UTR longa de 643pb.

O códon de início da tradução se encontra na posição 1 , o stop códon se encontra na posição $787 \mathrm{pb}$. Foram encontrados dois sinais de poliadenilação, um na posição $929 \mathrm{pb}$ e o outro na posição $1380 \mathrm{pb}$. A cauda de poli A se encontra presente. As 6 pontes dissulfetos preditas por similaridades seriam entre as cisteínas 7-141, 28-44, 78-236, 120-190, 152-169, 180-205 (figura 34). Podemos observar nas tabelas 13 e 14 a comparação com as cinco seqüências mais similares de cDNA e precursores de serino proteases de venenos de serpentes presentes no banco de dados do NCBI. A seqüência de CDNA e o precursor que apresentaram maior homologia com este clone PST7:3 foram respectivamente: Tlg2b de Trimeresurus gramineus e stejnobin de Trimeresurus stejnegeri.

A SVSP mais homóloga com a parte correspondente da toxina madura foi bilineobin de Agkistrodon bilineatus (tabela 24). 


\subsubsection{3- Análise do clone PST7:4.}

Podemos observar na figura 24 a presença de 5 regiões correspondentes aos éxons do gene de batroxobin mostradas na figura 27 e na tabela 21: éxon 1 (1-52pb), éxon 2 (53-209pb), éxon 3 (210-473pb), éxon 4 (474-620pb) e éxon 5 (621-1401). A tríade catalítica se encontra nos éxons: 2 (H67), 3 (D112) e 5 (S208). O sítio potencial de $\mathrm{N}$-glicosilação foi encontrado na asparagina 105 e o de O-glicosilação na treonina 152.

O cDNA se subdivide em uma região de $54 \mathrm{pb}$ que codifica para o peptídeo sinal de 18 aminoácidos, uma região de $18 \mathrm{pb}$ que codifica para o pró-peptídeo de 6 aminoácidos, uma região de $714 \mathrm{pb}$ que codifica para a toxina madura de 238 aminoácidos e uma região $3^{\prime}$ UTR longa de $643 \mathrm{pb}$. O códon de início da tradução se encontra na posição 1 , o stop códon se encontra na posição $787 \mathrm{pb}$ e o sinal de poliadenilação na posição $1381 \mathrm{pb}$. A cauda de poli A se encontra presente. Apresenta 6 pontes dissulfetos preditas por similaridades entre as cisteínas 7-141, 28-44, 78-236, 120-190, 152-169, 180-205 (figura 34).

Nas tabelas 15 e 16 são mostradas a comparação com as cinco seqüência mais similares de CDNA e precursores de serino proteases do veneno de serpentes presentes no banco de dados do NCBI. A seqüência de CDNA e o precursor que apresentaram maior homologia com este clone PST7:4 foram respectivamente: Tlg2b de Trimeresurus gramineus e stejnobin de Trimeresurus stejnegeri.

A SVSP mais homóloga com a parte correspondente da toxina madura foi stejnobin de Trimeresurus stejnegeri (tabela 24).

\subsubsection{4- Análise do clone PST7:7e8.}

$\mathrm{Na}$ figura 25 podemos observar a presença de 4 possiveis regiões correspondetes aos éxons de batroxobin mostradas na figura 27 e na tabela 21: éxon 1 (1-52pb), éxon 2 (52-200pb), éxon 3 (201-460pb), éxon 4 (461$611 \mathrm{pb})$ e éxon 5 (612-1398). A tríade catalítica se encontra nos éxons: 2 (H64), 3 (D109) e 5 (S205). Os sitios potenciais de $\mathrm{N}$-glicosilação encontrados foram nas asparaginas 78 e 102 e o de O-glicosilação nas treonina 148 e 256.

O cDNA se subdivide em uma região de $54 \mathrm{pb}$ que codifica para o peptídeo sinal de 18 aminoácidos, uma região de $18 \mathrm{pb}$ que codifica para o pró-peptídeo de 6 aminoácidos, uma região de $705 \mathrm{pb}$ que codifica para a 
toxina madura de 235 aminoácidos e uma região 3'UTR longa de 702pb. O códon de início da tradução se encontra na posição 1 , o stop códon se encontra na posição $778 \mathrm{pb}$ e o sinal de poliadenilação na posição $1372 \mathrm{pb}$. A cauda de poli A se encontra presente. As 6 pontes dissulfetos preditas por similaridades seriam entre as cisteínas 7- 138, 25-41, 73-233, 117-187, 145$162,173-198$ (figura 34). Podemos observar nas tabelas 17 e 18 as cinco sequências mais similares de CDNA e precursores de serino proteases do veneno de serpentes presentes no banco de dados do NCBI. A seqüência de cDNA e o precursor que apresentaram maior homologia com este clone PST7:7e8 foram respectivamente: preprotrimubin de Trimeresurus mucrosquamatus e serino protease CL5 de Trimeresurus stejnegeri.

A SVSP mais homóloga com a parte correspondente da toxina madura foi a serino protease CL5 de Trimeresurus stejnegeri (tabela 24).

\subsubsection{4- Análise do clone PST7:5.}

Com relação à organização do cDNA deste clone (figura 26) podemos observar a presença de 4 regiões correspondentes aos éxons do gene de batroxobin mostradas na figura 27 e tabela 21: éxon 1 (1-52pb), éxon 2 (53209pb), éxon 3 (210-469pb) e éxon 5 (470-1255), sendo que o éxon 4 se encontra ausente neste clone. Os aminoácidos pertencentes à tríade catalítica se encontram nos éxons: 2 (H67) e 3 (D112).

O cDNA se subdivide em uma região de $54 \mathrm{pb}$ que codifica para o peptídeo sinal de 18 aminoácidos, uma região de $18 \mathrm{pb}$ que codifica para o pró-peptídeo de 6 aminoácidos, uma região que codifica para a toxina madura que vai da posição 73 a $471 \mathrm{pb}$ e se encontra interrompida por um stop códon na posição $472 \mathrm{pb}$ e uma região $3^{\prime}$ UTR longa de $702 \mathrm{pb}$. O códon de início da tradução se encontra na posição 1 e o sinal de poliadenilação na posição $1235 \mathrm{pb}$. A cauda de poli $\mathrm{A}$ se encontra presente. O sítio potencial de $\mathrm{N}$ glicosilação se encontra na asparagina 105 e não foi encontrado nenhum sítio potencial de O-glicosilação. A seqüência codificante do clone PST7:5 apresenta um stop códon que interrompe a toxina madura. A comparação desta seqüência com banco de dados de nucleotideos e proteínas pode-se constatar que se encontra interrompida. Nas tabelas 19 e 20 estão as cinco seqüências mais similares de CDNA e precursores de serino proteases do veneno de serpentes presentes no banco de dados do NCBI. A seqüência de CDNA e o 
precursor de serino protease do veneno de serpente que apresentaram maior homologia com o clone PST7:5 foram respectivamente: Tlg2b de Trimeresurus gramineus e salmobin de Gloydius halys.

\subsubsection{Comparação dos cDNA dos clones B2.1, GPSs e PST7s com os éxons do gene de Batroxobin.}

Como encontramos seqüências longas (completas) e curtas (interrompidas), foi realizado um estudo da organização do cDNA em relação aos éxons usando-se o programa Spidey. Para esta análise, o gene de batroxobin foi utilizado como referência para análise da organização do cDNA dos clones (B2.1, GPS:2e5, GPS:3e4, PST7:3, PST7:4, PST7:5 e PST7:7e8). Observou-se que todas as seqüências mostraram a mesma organização do cDNA da batroxobin permitindo estimar qual região do cDNA é codificada pelo éxon específico, tal como mostra a figura 27 e a tabela 21 .

O clone B2.1 apresenta as regiões dos éxons 2, 3, 4 e 5. Entretanto, a região do éxon 5 é mais curta, 333 pb para B2.1 quando comparados com a mesma região no cDNA de batroxobin que tem 723 pb e inclusive em relação aos outros clones PST7 da mesma biblioteca. Apesar disso, este clone parece ter regiões $3^{\prime} U T R$ completas apresentando o stop códon e o sinal consenso de poliadenilação, além da cauda poliA $\left(^{+}\right)$. No entanto este clone não apresenta o éxon 1 que corresponde à região do 5 'UTR e a região codificante para o peptídeo sinal e pro-peptídeo, devido a estratégia de clonagem, pois foi amplificado com os primers GYR SE, que codifica para os 24 primeiros nucleotídeos da região que codifica o início do $\mathrm{N}$-terminal da giroxina de Crotalus durissus terrificus, e antisense $T 7$ que é complementar a uma região flanqueadora do sítio de clonagem do vetor $\lambda$-ZAP-XR da biblioteca.

Os clones GPS:2e5 e GPS:3e4 apresentam todos os cinco éxons, sendo o último éxon 5 parcial, pois é limitada pelo primer antisense GYR AS1, faltando toda a 3'UTR. A região do éxon 1 está quase completa, com $234 \mathrm{pb}$ no clone GPS:2e5 e 239 pb no clone GPS:3e4, correspondendo à mesma região no gene batroxobin (240pb) e compreende parte da região $5^{\prime} U T R$, apresenta a região de Kozak que determina o códon iniciador da tradução e a quase do peptídeo sinal.

Os segmentos do cDNA correspondentes aos éxons 2, 3 e 4 também estão completos e compreendem a seqüência codificante para o fim do 
peptídio sinal e as regiões codificantes para a toxina madura de maneira análoga ao cDNA de batroxóbin.

Os clones PST7:3, PST7:4, PST7:5 e PST7:7e8 não apresentam a região $5^{\prime}$ UTR, pois é limitada pelo primer peptídeo sinal PS sense, apenas parte codificadora do cDNA correspondente ao primeiro éxon está representado. Assim sendo, o cDNA é completo em relação às regiões codificadoras e $3^{\prime}$ UTR correspondentes aos éxons $2,3,4$ e 5, exceto no caso do clone PST7:5.

No clone PST7:5 nota-se a total ausência da região correspondente ao éxon 4, possivelmente devido a um "erro" de edição ("splicing") na remoção dos introns, ocorrendo uma união do éxon 3 diretamente com o éxon 5. Essa ausência do éxon 4 justifica a interrupção da proteína pela presença do stop códon conforme descrito no subitem anterior.

Nestes clones PST7s a região correspondente ao éxon 5 é longa ( 780 $\mathrm{pb})$, estendendo-se entre o stop códon e o sinal de poliadenilação que está presente em todos os clones. A região $3^{\prime} U T R$ desses clones é inclusive mais longa em comparação com o éxon 5 do batroxobin que contém 723 pb.

\subsection{Análise das seqüências de cDNA e de proteínas dos clones obtidos.}

\subsubsection{Alinhamento e Dendrograma.}

O dendrograma gerado pelo alinhamento de nucleotídeos dos clones de cDNA B2.1, GPS:2e5, GPS:3e4, PST7:3, PST7:4, PST7:5, PST7:7 se encontra na figura 28 . É possível observar que os clones se dividem em 3 grupos distintos: (I)- GPS:2e5, B2.1 e PST7:3; (II)- PST7:4, GPS:3e4 e PST7:5 e (III)-PST7:7e8

Os valores de similaridade em porcentagem da tabela 22 refletem os grupos de similaridades observados no dendrograma, mostrando que os clones de CDNA pertencentes a um mesmo grupo apresentam uma elevada similaridade e que o clone de CDNA PST7:7e8 é o mais divergente. As similaridades entre as seqüencias de cDNA variam de $99,87 \%$ a $83,21 \%$ $(\Delta=16,66 \%)$ e entre as seqüências das toxinas maduras variam de $99,57 \%$ a $77,21 \%(\Delta=22,36 \%)$, ou seja, há mais variações nas seqüências das toxinas maduras do que nas seqüências de cDNA. 
O alinhamento de nucleotídeos e aminoácidos destes mesmos clones se encontra na figura 29. O clone PST7:7e8 por ser o mais divergente está destacado na caixa de cor cinza claro.

É possivel observar que o clone PST7:3 apresenta 2 possíveis sinais de poliadenilação ( $5^{\prime}$-AATAAA-3') nas posições $929 \mathrm{pb}$ e $1380 \mathrm{pb}$, sendo que o primeiro sinal de poliadenilação alinha com o sinal de poliadenilação do clone B2.1 que se encontra na posição $857 \mathrm{pb}$. Os demais clones apresentam $\mathrm{G}$ no lugar de $T$ na mesma região alinhada com o sinal de poliadenilação do clone B2. Os sinais de poliadenilação dos clones PST7:4, PST7:5 e PST7:7e8 se encontram respectivamente nas posições: $1381 \mathrm{pb}, 1235 \mathrm{pb}$ e $1372 \mathrm{pb}$.

\subsubsection{Análise do peptídeo sinal dos precursores.}

A figura 30 mostra a comparação das seqüências de aminoácidos dos precursores (deduzidas a partir do CDNA) com as de toxinas maduras (isoladas do veneno). De maneira similar ao que foi mostrado no caso do cDNA (figura 21), os peptídeos sinais são muito conservados em serpentes evolutivamente próximas (cascavéis norte americanas) e distantes da cascavel sul americana (Trimeresurus, Bothrops e Agkistrodon), existindo algumas diferenças nas seqüências de nucleotídeos (figura 21) que pode ocasionar em mudanças no aminoácido (figura 30), que será abordado posteriormente na discussão.

O peptídeo sinal apresenta 18 aminoácidos sendo clivado após a alanina (A) no aminácido no 18, o pró-peptídeo apresenta 6 aminoácidos das posições de $n^{0} 19$ a 24 e a toxina madura começa na posição n०25 com os aminoácidos valina ( $V$ ) ou isoleucina (I) pois a seqüência de aminoácidos da toxina madura ancrod de Agkistrodon rhodostoma começa em valina (V) aminoácido no 25.

A predição de clivagem do clone PST7:3 foi realizado pelo programa SignalP revelando a presença das seguintes regiões: $n$ aminoácidos carregados postivamente, $\mathrm{h}$ região transmembrânica de hidrofobicidade e $\mathrm{c}$ a região que contém aminoácidos mais polares na região do C-terminal que define o sítio de clivagem (figura 31) (VON HEIJNE, 1985). 


\subsubsection{Análise das toxinas maduras.}

O alinhamento em aminoácidos apenas da parte madura dos clones B2.1, GPS:2e5, GPS:3e4, PST7:3, PST7:4, PST7:7e8 gerou um dendrograma apresentado na figura 32. A seqüência de aminoácidos do clone PST7:5 não foi alinhada devido a ausência da região correspondente ao éxon 4 apresentando um stop códon como mostrada na figura 26.

Podemos observar a presença de três grupos distintos: (I)-PST7:4 e GPS:3e4; (II)-GPS:2e5, B2.1 e PST7:3 e (III)-PST7:7e8. Estes dados estão de acordo com o dendrograma de cDNA dos clones (figura 28), na qual observamos 3 grupos formados pelos mesmos clones.

A tabela 23 confirma o dendrograma, mostrando que as toxinas maduras pertencentes a um mesmo grupo apresentam uma elevada similaridade entre si e que a toxina madura PST7:7e8 é a mais divergente.

\subsection{Comparação das toxinas maduras dos clones obtidos com outras toxinas.}

A tabela 24 mostra sequências de serino proteases de venenos de serpentes mais similares a cada toxina madura. O clone PST7:5 conforme descrito anteriormente não foi analisado porque falta a região correspondente ao éxon 4 apresentando um stop códon. Podemos observar que os clones B2.1, GPS:2e5, PST7:3 apresentaram alta similaridade de $79-80 \%$ com Bilineobin (Agkistrodon bilineatus), os clones GPS:3e4 e PST7:4 apresentaram $78 \%$ similaridade com Stejnobin de Trimeresurus stejnegeri e o clone PST7:7e8 apresentou 77\% de similaridade com serine protease CL5 precursor de Trimeresurus stejnegeri, ou seja os clones pertencentes ao mesmo grupo das figuras 28 e 32 foram homólogos à mesma toxina, sendo o clone PST7:7e8 o mais divergente.

$\mathrm{Na}$ figura 33 podemos observar um dendrograma funcional gerado pelo alinhamento das toxinas maduras dos clones com 29 outras seqüências de toxinas conhecidas. No dendrograma encontramos quatro grupos de toxinas sendo que o grupo I ativam o fator $V$ da cascata de coagulação, o grupo II ativam o plasminogênio, o grupo III são fibrinogenases que se subdivide em dois grupos: IIIa- $\alpha$ fibrinogenases (venombina $A$ ) e IIIb- $\alpha$ e/ou $\beta$ fibrinogenases (venombinas $A$ e/ou $B$ ) e o grupo IV são enzimas trombinasímile que se subdivide em dois grupos: IVa-enzimas que atuam sobre a 
coagulação e IVb- enzimas que pertencem ao grupo da toxina ativadora de proteina $C$ (ACC-C) de Agkistrodon contortrix contortrix. Nos ramos do dendrograma encontramos serpentes de diferentes espécies organizadas por similaridade em grupos de mesma atividade biológica evidenciando que o dendrograma reflete uma possível diferença funcional de cada toxina.

A figura 34 apresenta o alinhamento das toxinas maduras dos clones obtidos e algumas outras analisadas no dendrograma funcional. As 6 pontes dissulfetos se encontram entre as seguintes cisteínas 7-141, 28-44, 78-236, 120-190, 152-169, 180-205 e os aminoácidos que compõem a tríade catalítica (H43), (D88) e (S184). A numeração das pontes dissulfetos e dos aminóacidos da tríade catalítica foram baseadas na seqüência da giroxina-simile B2.1 mostrada na figura 18.

\subsection{Modelo tridimensional.}

Pela primeira vez foi realizado um modelo tridimensional da giroxina B2.1 que permitiu estudar a conformação do sítio catalítico, as pontes dissulfetos, o exosítio de ligação ao fibrinogênio e a comparação com outras estruturas de serino proteases, para esse fim foi realizado um modelo estrutural da crotalase.

O modelo tridimensional foi baseado na seqüência do clone B2.1 foi realizado por modelagem de homologia com os modelos cristalográficos de AaV-SP-I (1opO) e AaV-SP-II/DAV-PA (1op2) de Agkistrodon acutus. Na figura 35 o modelo tridimensional do clone B2.1 é comparado com os modelos cristalográficos da TSV-PA (1bqy), DAV-PA (1op2) e da tripsina. Pode-se observar nos três modelos a presença das 6 pontes dissulfetos em azul, a presença de dois barris- $\beta$ de terminação aberta (em amarelo), dispostos em ângulo reto um em relação ao outro e duas $\alpha$-hélices (vermelho), sendo uma delas C-terminal.

As serino proteases do veneno de serpente apresentam um segmento C-terminal mais longo que as outras serino proteases; este é estabilizado pela última ponte dissulfeto e localizado em posição geométrica que difere da tripsina cujo C-terminal é mais curto e composto unicamente pela $\alpha$-hélice.

No modelo de superfície da giroxina mostrado na figura 35 é possível visualizar a asparagina $81 \mathrm{em}$ azul e o ponto do possível sítio de glicosilação 
em vermelho, em verde é mostrado a tríade catalítica no fundo da fenda do sítio proteolítico. No modelo da DAV-PA o monossacarídeo $N G^{301}$ está na asparagina 35 , mostrada em magenta.

A figura 36 mostra o modelo tridimensional da giroxina e a comparação com o modelo cristalográfico da tripsina (2ptc) permitindo observar a sobreposição da região da tríade catalítica dos dois modelos.

A figura 37 identifica o exosítio de ligação ao fibrinogênio na $\alpha$ trombina e na crotalase (roxo) e evidencia um exosítio alternativo presente na crotalase (rosa) e ausente na $\alpha$-trombina (MASSOVA et al, 1996). Comparando-se o modelo da giroxina com o da crotalase, é possivel encontrar os mesmos aminoácidos que compõem os dois exosítios, o de ligação ao fibrinogênio e o alternativo.

\subsection{Construção do vetor de expressão pED-Giro.}

O passos de subclonagem necessários para produzir o vetor pED-Giro são mostrados na figura 12.

O seqüenciamento do clone B2.1 mostrou que este CDNA foi inserido no vetor PCR2.1 TOPO em sentido oposto ao promotor do LacZ (figura 38).

\subsubsection{Obtenção do inserto da giroxina madura.}

O vetor pCR2.1 Giro após ser clivado com as enzimas de restrição SpeI (extremidade coesiva preenchida com Klenow DNA pol. I) e Not I, gerou o inserto da giroxina B2.1 (943pb) contendo a extremidade coesiva Not I a 5' e a extremidade cega $3^{\prime}$.

\subsubsection{Preparo do vetor pSecTag2 Hygro $A$.}

O vetor pSecTag2 Hygro A após ser digerido com as enzimas de restrição Xho I (a extremidade coesiva tratada com klenow da DNA pol. I) e Not I, gerou um fragmento de DNA de 5700 pares de bases $(\mathrm{pb})$ contendo a extremidade coesiva Not I à $5^{\prime}$ e a extremidade cega a $3^{\prime}$.

\subsubsection{Seleção do clone pSecTag2-Giro.}

O fragmento de giroxina após ser inserido no vetor pSecTag2 HygroA e realizado a seleção das colônias recombinantes, a figura 40 mostra que 
somente 0 clone 1 apresentou um tamanho aparente maior que o vetor vazio (não recombinante), sendo provavelmente um clone positivo, correspondendo ao plasmídeo pSecTag2 Giro. Entretando todos os outros clones aparentavam ser negativos e para confirmar esse fato as alíquotas da suspensão bacteriana dos clones 1 (recombinante), 2, 3 e 4 e do vetor vazio (não recombinantescontroles negativos) foram utilizados na reação de PCR, com os primers: GYR SE e GYR AS1.

$\mathrm{Na}$ figura 41 podemos observar que somente o clone 1 foi amplificado, confirmando que este clone contém o inserto correto.

O seqüenciamento do clone pSecTag2-Giro mostra que o inserto de giroxina B2.1 não está em fase de leitura em relação ao peptídeo sinal de Igk, devido a presença de um fragmento do sítio policlonal do vetor pCR2.1 TOPO (LaZ mostrado em azul na figura 39) portanto o precursor não será formado nem clivado e não resultando em uma giroxina-símile madura funcional. Para tanto foi necessário realizar a mutagênese sítio dirigida para retirar os nucleotídeos correspondentes a região LacZ presentes entre o peptídeo sinal e o inserto de giroxina B2.1 sendo o esquema mostrado na figura 12.

\subsubsection{Seleção do clone mutante pSecTag2 Igk-Giro.}

$\mathrm{Na}$ figura 42 os clones que apresentaram um tamanho aparente menor do que os clones controles (vetor parental pSecTag2-Giro antes da mutagênese), no caso os clones 4, 5, 6, 8 e 12 provavelmente sofreram a mutagênese e contém o plasmideo mutante pSecTag2 Igk-Giro, perdendo aproximadamente as 133 pares de bases.

Os clones 4,6 e 8 foram escolhidos aleatoriamente e submetidos a uma extração do DNA plasmidial e em seguida foram digeridos com as enzimas de restrição Not I, Eco RV e Bam HI com a finalidade de verificar a perda desses sítios de restrição que estão presentes no sítio de policlonagem do vetor parental pSecTag2-Giro, na região que se desejava deletar (figura 43). No vetor parental ao clivar com a enzima de restrição Bam HI, ocorre a liberação de um inserto, pois existem 2 sítios de Bam HI, um na giroxina madura e outro na região que se deseja deletar sendo o esquema mostrado na figura 39. Já nos clones mutantes (pSecTag2-IgK-Giro) não há liberação de inserto, apenas linearização do plasmídeo, porque só existe 1 sítio de Bam HI 
na giroxina madura, o outro sítio é perdido nos mutados conforme esquema mostrado na figura 44.

A reação de mutagênese foi confirmada pelo seqüenciamento, utilizando-se o primer antisense interno a giroxina GYR AS2 (a região de hibridação do primer é mostrada na figura 29), mostrando que o inserto da giroxina ficou em fase de leitura com o peptídeo sinal de IgK e a seqüência intercalante foi deletada conforme mostrado na figura 44 sendo o clone 4 (pSecTag-IgK-Giro) escolhido para dar continuidade com a subclonagem no vetor de expressão pED. Para certificarmos que o peptídeo sinal será corretamente clivado a seqüência foi submetida ao SignalP 3.0.

\subsubsection{Obtenção do inserto IgK-Giro.}

O clone 4 pSecTag2 IgK-Giro após ser digerido com as enzimas de restrição Xho I ( a extremidade coesiva foi preenchida com Klenow da DNA pol I para gerar uma extremidade em ponta cega) e Nhe I, gerou o fragmento IgK-Giro de $968 \mathrm{pb}$ contendo uma extremidade $5^{\prime}$ coesiva (NheI) e uma extremidade cega a $3^{\prime}$

\subsubsection{Preparo do vetor $P E D$ para subclonagem do inserto IgK-Giro.}

O plasmídeo pED após ser digerido com as enzimas de restrição Xba I e Sma I, obteve-se um fragmento de DNA de 5730 pares de bases (pb) contendo a extremidade coesiva Xba I a 5' e a extremidade cega Sma I a 3'.

\subsubsection{Seleção do clone pED-Giro.}

O fragmento IgK-Giro após ser ligado no vetor pED, é possível observar na figura 45 que a colônia 3, apresentou um tamanho aparente maior que o vetor vazio (não recombinante), sendo provavelmente o clone positivo (pED-Giro).

Para confirmar a presença do inserto IgK-Giro no clone 3, as alíquotas da suspensão bacteriana dos clones foram analisados por PCR. Entretando todos os outros clones aparentavam ser negativos, para confirmar esse fato foi escolhido um clone aleatoriamente (clone 12) e o vetor vazio (não recombinante) sendo utilizados como controles negativos da reação de PCR, com os primers: GYR SE e GYR AS1. 
Podemos observar na figura 46 que somente o clone 3 foi amplificado, confirmando a presença do inserto IgK-Giro inserida no vetor pED conforme esquema mostrado na figura 47.

Após a extração do DNA plasmidial pED-Giro do clone 3, foi realizada a transfecção nas células CHO-DXB11 dhfr'.

\subsection{Expressão do vetor pED-Giro em células CHO DXB11 dhfr'.}

\subsubsection{Seleção e amplificação dos clones.}

Após a transfecção, os clones celulares foram isolados (figura 48). Durante o período de amplificação algumas dificuldades foram encontradas: muitos clones morreram ao aumentar a concentração de MTX, outros clones demoraram mais de 3 semanas para chegar a semi-confluência e passar para a próxima etapa de amplificação totalizando 6 meses de cultivo, selecionando os clones até $1280 \mathrm{nM}$ de MTX.

\subsection{2- Detecção da proteína recombinante expressa pelo vetor pED-} Giro em células CHO DXB11 por SDS-PAGE e western blot

Nos clones que sobreviveram, em diferentes concentrações de MTX, a análise do extrato celular não detectou a presença da giroxina recombinante em eletroforese em gel de poliacrilamida e western blot (dados não mostrados).

\subsubsection{Detecção do vetor pED-Giro integrado ao genoma da célula CHO-DXB11.}

Com o intuito de verificar se o vetor pED-Giro foi integrado ao genoma da célula CHO-DXB11, foi realizado um PCR com o extrato total da célula transfectada (clone 6) mostrada na figura 49. Ao utilizar os primers IgKSE/DHFR AS segundo o esquema mostrado na figura 13-A mostrou que o DNA genômico IgK-Giroxina-dhfr está inteiro presente no clone 6 (canaleta 2) e no plasmídeo pED-Giro (canaleta 3) com uma banda de aproximadamente $2100 \mathrm{pb}$, conforme mostrado na figura 49-A. Não houve amplificação ao utilizar a célula CHO-DXB11 dhfr não transfectada (canaleta 1), sendo o esperado. 
No entanto o clone 6 (canaleta 5) ao ser amplificado com os primers IgK SE/GYR AS1 segundo esquema mostrado na figura 13-B resultou em 2 bandas, na qual uma banda está na altura do plasmídeo pED-Giro (canaleta 6) de aproximadamente $780 \mathrm{pb}$ e a outra banda se encontra na mesma altura que a banda presente na célula CHO-DXB11 dhfr não transfectada (canaleta 4), de acordo com a figura 49-B. Esta banda deve estar relacionada com seqüências presentes no DNA genômico da célula CHO-DXB11 dhfr complementares aos primers específicos para a giroxina.

Os primers DHFR SE/AS amplificaram a região do dhfr segundo o esquema mostrado na figura $13-C$ presente no clone 6 (canaleta 8 ) e no plasmídeo pED-Giro (canaleta 9) com uma banda de aproximadamente $600 \mathrm{pb}$ de acordo com a figura 49-C. Na canaleta 7 a célula CHO-DXB11 dhfr não transfectada, não amplificou com estes primers conforme o esperado. $\mathrm{Na}$ canaleta 10 ao ser utilizada água na reação não amplificou nenhuma banda, ou seja, não houve contaminação e as amplificações foram específicas conforme mostrada na figura 49.

\subsubsection{Detecção do mRNA expresso pela célula CHO-DXB11x pED-Giro.}

As extrações dos RNAs totais dos clones 4, 8 na ausência de MTX, clones 4 e 8 na presença de 20nM MTX e da célula controle negativo CHO-K1 $d h f r^{+}$, ocorreram com sucesso pois as bandas recombinantes dos RNAs ribossomais se encontram íntegras (figura 50 ).

Devido à intensa densidade celular da célula controle negativo $\mathrm{CHO}-\mathrm{K} 1$ $\mathrm{dhfr}^{+}$(canaleta 1) e dos clones 8 sem MTX (canaleta 2) e 4 sem MTX (canaleta 4), estes foram reservados para realizar o ensaio de RT-PCR e os clones $8 \mathrm{com}$ 20nM de MTX (canaleta 3) e 4 com 20nM de MTX (canaleta 5) devido a baixa intensidade celular não foram utilizados nesse ensaio.

A concentração dos RNAs totais em uma absorbância de $260 \mathrm{~nm}$ foram CHO-K1 dhfr': $1245 \mathrm{ng} / \mu \mathrm{l}$; clone 4: $696 \mathrm{ng} / \mu \mathrm{l}$ e clone $8: 884 \mathrm{ng} / \mu \mathrm{l}$.

$\mathrm{Na}$ figura 51 ao utilizar $3,5 \mu \mathrm{g}$ de RNA total isolado das amostras, com os primers GYR SE e DHFR AS segundo o esquema mostrado na figura 14-A, podemos observar na figura 51- A que não ocorreu nenhuma amplificação na célula CHO-K1 dhfr ${ }^{+}$e nos clones 4 e 8 (canaletas 1 a 3), ou seja, não há a 
formação de um único mRNA giroxina-dhfr. Mas ao utilizar os primers GYR SE/AS1 segundo o esquema mostrado na figura $14-C$ podemos observar na figura 51-C a presença de uma banda na célula controle negativo $\mathrm{CHO}-\mathrm{K} 1$ $d h \mathrm{fr}^{+}$e nos clones 4 e 8 (canaletas 4,5 e 6) de aproximadamente 700pb.

Ao utilizar os primers DHFR SE/AS segundo o esquema mostrado na figura 14-B podemos observar na figura $51-B$ a presença de uma banda de aproximadamente $600 \mathrm{pb}$ na célula controle negativo $\mathrm{CHO}-\mathrm{K} 1 \mathrm{dhfr}^{+}$e nos clones 4 e 8 (canaletas 7,8 e 9 ) na mesma altura que o controle positivo pEDGiro amplificado com o mesmo par de primers (canaleta 10). A célula CHO-K1 $d h \mathrm{fr}^{+}$amplificou uma banda pois é uma linhagem que não apresenta deficiência do gene dhfr e a presença das bandas nos clones 4 e 8 (pED-Giro transfectado na célula CHO-DXB11 deficientes do gene $d$ hfr) indica a presença do dhfr proveniente do plasmídeo pED-Giro presente nos clones transfectados.

Nesse ensaio de RT-PCR as sequências dos primers GYR SE/AS 1 amplificou uma seqüência do mRNA presente na célula CHO-K1 dhfr', confirmando o resultado, anterior em que esse mesmo par de primer amplificou uma banda presente na célula CHO-DXB11 dhfr. O mRNA da giroxina está presente mas em uma baixa concentração e se encontra separado do mRNA dhfr.

Como na célula CHO-K1 $\mathrm{dhfr}^{+}$amplificou uma banda com os primers GYR SE/AS1, fomos verificar por RT-PCR se na célula não transfectada CHODXB11 dhfr', também apresentava ou não a mesma amplificação. Além disso nesse RT-PCR fomos verificar se o dicistron mRNA IgK-giroxina-dhfr realmente se encontra clivado.

Um novo ensaio de RT-PCR foi realizado com $8 \mu \mathrm{L}$ de RNA total dos clones 4 e 6 sem tratamento com MTX, clones 4 com 20nM de MTX e 6 com 320nM de MTX e como controle negativo as células CHO-DXB11 dhfr. As extrações dos RNAs totais dessas amostras ocorreram com sucesso, pois da mesma forma que a extração descrita anteriormente, as bandas recombinantes dos RNAs ribossomais se encontram integras (figura 52). Podemos observar que o clone 4 (canaleta 1) apresentou uma menor intensidade, influenciando no próximo resultado. 
As concentrações do RNA das amostras em $\mathrm{ng} / \mu \mathrm{L}$ e as concentrações em $\mu \mathrm{g}$ do RNA total utilizado na reação se encontram na tabela 25 e o RNA total isolado das amostras se encontra na figura 53.

Ao utilizar os primers IgK SE e DHFR AS segundo o esquema mostrado na figura $14 \mathrm{D}$, não ocorreu nehuma amplificação, ou seja, não há a formação de um único mRNA dicistrônico IgK-giroxina-dhfr conforme mostrado na figura 53-D. Ao utilizar os primers IgK SE e GYR AS1 segundo o esquema mostrado na figura $14 \mathrm{~F}$, a presença de bandas dos clones 4 com 20nM MTX, 6 e $6 \mathrm{com}$ 320nM MTX (canaletas 7,8 e 9) na altura do controle positivo pED-Giro amplificado com o mesmo par de primers (canaleta 17) de aproximadamente $780 \mathrm{pb}$ e a ausência de banda na célula controle negativo CHO DXB11 dhfr (canaleta 10) revela a presença do mRNA giroxina nos clones transfectados no entanto separado do mRNA- $d h f r$ conforme mostrado na figura $53 \mathrm{~F}$.

Na figura 53-F o clone 4 não amplificou com os primers Igk SE/GYR AS1 (canaleta 6), pois foi utilizada uma baixa concentração de RNA $(1,6 \mu \mathrm{g})$ na reação de RT-PCR sendo que o mesmo clone 4 amplificado com 20nM MTX ao ser colocado 5,4 $\mathrm{g}$ de RNA na reação de RT-PCR conforme mostrado na tabela 25, amplificou uma banda (canaleta 7) na altura do controle positivo pED-Giro (canaleta 17), indicando a presença do mRNA giroxina do vetor pEDGiro.

Ao utilizar os primers DHFR SE/AS segundo o esquema mostrado na figura $14 \mathrm{E}$ verificou-se a presença de bandas dos clones 4, 4 com 20nM MTX, 6 e 6 com 320nM MTX (canaletas 1 a 4) na mesma altura do controle positivo pED-Giro amplificado com o mesmo par de primers (canaleta 16) de aproximadamente $600 \mathrm{pb}$, indica a presença da região do $d h f r$ proveniente do plasmídeo pED-Giro presente nos clones transfectados conforme mostrado na figura $53 \mathrm{E}$. A ausência da banda na célula controle negativo CHO-DXX11 $d h f r^{2}$ (canaleta 5), está de acordo com o esperado. A intensidade da banda obtida para dhfr é muito maior que a intensidade do mRNA-giroxina confirmando que o mRNA da giroxina está separado do mRNA dhfr.

Ao utilizar somente água na reação não houve nenhuma amplificação (canaleta 19), ou seja, não houve contaminação e as amplificações foram específicas. 


\subsection{Expressão transiente do vetor pED-Giro em células cos-7.}

Após realizar a transfecção com os plasmídeos pSecTag2-IgK-Giro e pED-Giro e como controle positivo o pGEF-N1 a transfecção ocorreu com sucesso, pois em torno de $90 \%$ das células COS-7 estão expressando a proteína fluorescente GFP conforme mostrado na figura 54-A. O mesmo deverá ter ocorrido com as transfecções dos clones pED-Giro (figura 54-B) e pSecTag-IgK-Giro.

\subsubsection{Purificação do produto recombinante expresso pelo vetor pED- Giro em células cos-7.}

Durante o processo de purificação foi utilizado a mesma quantidade de resina de afinidade benzamidina em todas as amostras $(100 \mu \mathrm{L})$. O meio de cultura em que cresceram as células COS-7xpED-Giro $24 \mathrm{~h}$ foi utilizado para purificar com a resina de afinidade benzamidina. $O$ teste de atividade esterásica foi realizado com o meio de cultura antes e após a purificação apresentando respectivamente as atividades 541,8 (tabela 26-amostra F) e 0,5 (tabela 26-amostra I), ou seja, foi recuperado uma baixa concentração da proteína durante o processo de purificação apresentando uma baixa atividade especifica $\mathrm{U} / \mathrm{mg}$ de proteína, provavelmente porque a quantidade de proteína total excedeu a capacidade da resina.

Ao realizar a curva padrão da albumina bovina sérica o dado da curva padrão ajustados pelo programa Graph Pad Prims, pela regressão linear é: $y=$ $0,03521 x$.

\subsubsection{Deteç̧ão da proteína recombinante expressa pelo vetor pED-} Giro em células coS-7 por SDS-PAGE e western blot.

O perfil eletroforético da giroxina nativa purificada com a resina de afinidade benzamidina, reage com o soro policlonal anticrotálico do Instituto Butantan resultando em duas bandas com aproximadamente $33 \mathrm{kDa}$, sendo a primeira banda é mais intensa que a segunda (figura 55-B-canaletas 7 e 8 ). A giroxina recombinante expressa pelo plasmídeo pED-Giro reagiu com o soro anticrotálico apresentando o mesmo comportamento da giroxina nativa purificada, com a presença das duas bandas, a primeira mais intensa que a 
segunda e na mesma posição de $33 \mathrm{KDa}$, ou seja o plasmídeo pED-Giro expressou uma giroxina recombinante igual a giroxina encontrada no veneno.

O plasmídeo pSecTag-2 IgK-Giro expressou a giroxina recombinante, mas com uma intensidade muito menor que o plasmídeo pED-Giro, indicando que foi uma boa estratégia ter retirado a giroxina recombinante do pSecTagIgK-Giro e clonado no vetor pED de acordo com o esquema mostrado na figura 12.

Após uma nova transfecção do plasmídeo pED-Giro nas células COS-7, o "extrato celular bruto", o sobrenadante e o precipitado do lisado da célula, antes da purificação com a resina de afinidade benzamidina, o sobrenadante do lisado da célula e o meio de cultura $24 \mathrm{~h}$ após a transfecção do vetor pEDGiro nas células cos-7 foram purificados com a resina de afinidade benzamidina e analisados em gel de poliacrilamida e western blot (figura 56). Podemos observar que o gel de poliacrilamida corado com Comassie Blue (figura 56-A), mostra que a giroxina nativa purificada do veneno cora muito mal, pois com $3 \mu \mathrm{g}$ de giroxina purificada do veneno (canaleta 15 ) é possível observar somente 1 banda de intensidade fraca.

A amostra extrato celular COS-7 pED-Giro (canaleta 3), o sobrenadante do lisado da célula sonicada COS-7 transfectada com o plasmídeo pED-Giro (canaleta 5), o precipitado do lisado da célula COS-7 transfectada com o plasmídeo pED-Giro (canaleta 7) reagiram com o soro anticrotálico apresentando as mesmas duas bandas encontradas na giroxina nativa purificada do veneno, descrito anteriormente. No entanto essas bandas não se encontram na mesma posição que a giroxina nativa, pois esta sofreu uma distorção durante a corrida eletroforética (figura $56 \mathrm{~B}$ ).

A amostra precipitado do lisado da célula sonicada COS-7 pED-Giro (canaleta 7) se encontra 10x mais concentrada do que a amostra sobrenadante do lisado da célula sonicada cos-7 transfectada com o plasmídeo pED-Giro (canaleta 5), mostrando que uma parte do produto de expressão do vetor pED-Giro giroxina-símile B2.1 se encontra no precipitado celular e uma outra parte se encontra solúvel no sobrenadante após sonicação. Após incubar o sobrenadante do lisado da célula COS-7 transfectadas com o plasmídeo pED-Giro com a resina de afinidade benzamidina e realizar a eluição, não foi possível detectar a presença da proteína recombinante no material eluído (canaletas 8-13). Este fato é um 
indicativo que expressar direto no meio de cultura é uma boa estratégia pois auxilia na purificação da toxina recombinante sem a interferência do material celular.

O meio de cultura em que cresceram as células cos-7 24h após a transfecção com o plasmídeo pED-Giro antes da purificação também não foi possível ser visualizado pelo ensaio de western blot (dado não mostrado). Já o meio de cultura em que cresceram as células cos-7 24h após a transfecção com o plasmídeo pED-Giro incubado com resina de afinidade benzamidina reagiu com o soro anticrotálico sendo possivel observar a presença de duas bandas na mesma posição de $33 \mathrm{kDa}$ das bandas encontradas na giroxina nativa purificada do veneno após a concentração do material eluído (figura 56 C) demonstrando que a giroxina recombinante foi secretada para o meio de cultura.

Com a finalidade se verificar se a giroxina-símile B2.1 está sendo secretada no meio de cultura na forma ativa, foi realizado o teste de atividade esterásica.

\subsection{Ensaio de atividade enzimática da giroxina recombinante purificada por benzamidina sepharose.}

Os sobrenadantes do lisado celular e os meios de cultura foram incubados com a resina de afinidade Benzamidina Sepharose 6B com o intuito de detectar a presença da giroxina recombinante.

A figura 57 mostra a atividade esterásica da giroxina recombinante. $O$ controle negativo com o meio de cultura D-MEM apresentou uma pequena atividade esterásica sugerindo que algum componente presente pode ter essa atividade e foi considerada como basal. 0 sobrenadante do lisado da célula COS-7 (controle negativo das células) não apresentou nenhuma atividade, conforme o esperado. No entanto, o sobrenadante do lisado da célula COS-7 transfectada com o vetor $\mathrm{pED}$-Giro apresentou pequena atividade, um pouco acima do basal; o que está de acordo com a figura 56-B. Neste resultado anterior no sobrenadante do lisado após a purificação com a resina de afinidade, não foi detectada em western blot; considerando que o material celular é bastante viscoso pode ter ocorrido interferência com a purificação da proteina recombinante, resultando na baixa atividade esterásica. 
$\mathrm{Na}$ figura 57 verificamos que o meio de cultura em que cresceram as células COS-7 24h após a transfecção com o vetor pED-Giro apresentou uma elevada atividade $(\mathrm{U} / \mathrm{mL})$ indicando que a giroxina $B 2.1$ foi secretada e purificada do meio de cultura. Esse resultado está de acordo com a figura 56-C na qual observamos no western blot na canaleta 1 a presença da giroxina B2.1 purificada do meio de cultura em que cresceram durante célula COS-7 com o vetor pED-Giro durante 24h. O fato da giroxina B2.1 ser secretada para o meio de cultura facilita o processo de purificação, pois há poucas proteinas contaminantes.

No meio de cultura $48 \mathrm{~h}$ após a transfecção, apesar das células se encontrarem envelhecidas e provavelmente secretando metabólitos para o meio de cultura, ainda foi possível observar uma elevada atividade esterásica, no entanto menor do que a determinada no meio de cultura em 24h.

Concluindo, foi possivel realizar a construção de um vetor pED aliado a um peptídeo sinal IgK que secreta para o mejo de cultura a giroxina B2.1 recombinante ativa facilitando a purificação com o perfil eletroforético similar a giroxina nativa purificada do veneno. 


\section{5- DISCUSSÃO}

As enzimas dos venenos de serpentes caracterizadas como serino proteases (SVSPs) apresentam mecanismos catalíticos em comum, que inclui um resíduo de serina altamente reativo e importante na formação do complexo enzimático, o qual é estabilizado na presença dos residuos de histidina e ácido aspártico, que também fazem parte do sítio ativo (SERRANO et al, 2005) (figuras 3 e 4).

É conhecido que existem mais de 150 seqüências de SVSPs publicadas (WANG et al., 2001) a maioria obtida por seqüenciamento de cDNA. Apesar da grande similaridade na sua estrutura tridimensional estas toxinas variam muito em relação às funções, devido a diferenças sutis de aminoácidos da proteina sem afetar sua conformação global, pois existe uma pressão seletiva positiva para que toxinas de venenos atuem em diferentes alvos celulares e/ou diferentes presas animais, conferindo vantagem às espécies de serpentes que possuem novas e diferentes toxinas. Refletindo essa variabilidade funcional, a seqüência primária dos aminoácidos de determinadas regiões da toxina madura também é mais variável, enquanto outras, são estruturalmente conservadas. A variabilidade também se reflete nas diferentes atividades e alvos celulares com que elas interagem (coagulação, pressão arterial, inflamação entre outros).

Uma atividade peculiar é o rolamento em barril descrito originalmente para a giroxina e mais tarde, para a ancrod e crotalase (ALEXANDER et al, 1988). A giroxina é uma serino protease do veneno de cascavel Crotalus durissus terrificus (CAMILLO, 1998) e a ancrod e a crotalase também são SVSPS dos venenos de Agkistrodon rhodostoma e Crotalus atrox respectivamente, que agem sobre a coagulação (trombina-símile).

No caso do rolamento em barril não é conhecido o mecanismo que o gera assim como as relações estrutura/atividade envolvidas. Neste estudo foram obtidas e analisadas seqüências de SVSPS similares à giroxina que podem contribuir para esclarecer estes pontos. Assim o clone obtido com o primer específico desenhado para a região $\mathrm{N}$-terminal da giroxina foi denominado B2.1.

A seqüência do clone B2.1-giroxina revelou diferenças em relação aos 30 primeiros aminoácidos de giroxina anteriormente descritos em DA SILVA et 
al, 1989. Na figura 17 podemos observar que o seqüenciamento de giroxina obtido por Simpson e por Kaiser e a seqüência de aminoácidos do clone B2.1giroxina, obtida através do CDNA, apresentou duas diferenças de aminoácidos em relação a seqüência $N$-terminal descrito por Simpson $(R \rightarrow H$, posição no 12 e $Q \rightarrow E$, posição no 24).

Para ambos os casos a mutação encontrada pode ter sido ocasionada pela Taq DNA polimerase recombinante de baixa fidelidade utilizada na amplificação do gene.

A troca do aminoácido arginina ( $R$ ) para histidina $(H)$ pode ser uma mutação conservada que ocorre naturalmente uma vez que a característica físico-química em relação à carga positiva é preservada tornando essa mutação freqüente. Isto é válido também para o segundo caso, em que os aminoácidos glutamina $(Q)$ e ácido glutâmico $(E)$ são estruturalmente muito semelhantes, sendo esta mutação especialmente freqüente da mesma forma que é a mutação da asparagina $(N)$ e ácido aspártico $(D)$ verificado quando se alinha seqüências de proteínas e de cDNA. Por outro lado a diferença encontrada entre glutamina $(Q)$ e ácido glutâmico $(E)$ pode estar relacionada à desaminação da proteína, uma vez que o ácido glutâmico foi identificado por degradação de Edman.

Ao analisar os clones de cDNA amplificados B2.1 (figura 18), GPS:2e5 (figura 19), GPS:3e4 (figura 20), PST7:3 (figura 23), PST7:4 (figura 24) e PST7:7e8 (figura 25) podemos observar que apresentam a tríade catalítica HDS (histidina, ácido aspártico, serina), com exceção do clone PST7:5 que apresenta somente os aminoácidos $H$ e $D$ devido a ausência da seqüência correspondente ao éxon 4 (figura 26). Todos esses clones mostrados na figura 29 podem ser considerados serino proteases pertencendo à família de tripsina S1A, a maior família de serino proteases (SERRANO et al, 2005). A similaridade também está presente na conformação observada pela sobreposição da região da tríade catalítica que se encontra na fenda entre os dois barris- $\beta$ no clone B2.1 e na tripsina (figura 36 ).

Outra característica importante das serino proteases do veneno de serpentes é a glicosilação. Esta modificação pós-traducional está presente na maioria das células secretadas (GOOCHEE et al, 1991) sendo que as serino proteases do veneno de serpentes apresentam oligossacarídeos covalentemente ligadas em uma cadeia lateral de asparagina ( $\mathrm{N}$-glicosilação) 
e poucas serino proteases apresentam oligossacarídeos covalentemente ligados à cadeia lateral de treonina ou serina (O-glicosilação), sendo raras as serino proteases não glicosiladas como a trombina-símile contortrixobin de Agkistrodon contortrix contortrix e flavoxobin de Trimeresurus flavoviridis (AMICONI et al, 2000).

A glicosilação também está presente nas SVSPs e foi mais bem estudada em algumas proteínas como, por exemplo, a Bothrops protease A, a kangshuamei, a ancrod e a batroxobin (MURAYAMA et al 2003, SAKAI et al, 2006 e LOCHNIT \& GEYER, 1995).

Segundo MURAYAMA et al 2003, na Bothrops protease A (Bothrops jararaca) foram encontrados 8 sítios potenciais de $\mathrm{N}$-glicosilação e 2 sítios potenciais de $\mathrm{O}$-glicosilação na qual o experimento de deglicosilação confirmou que os 10 potenciais sítios estão presentes.

Os processos de $\mathrm{N}$-glicosilação e O-glicosilação estão descritos em GOOCHEE et al, 1991. Os clones de cDNA obtidos B2.1 (figura 18), GPS:2e5, (figura 19), PST7:3 (figura 23) e PST7:4 (figura 24) apresentam 1 potencial sítio de $\mathrm{N}$-glicosilação sendo encontrados 2 sítios nos clones GPS:3e4 (figura 20) e PST7:7e8 (figura 25). Com exceção do clone PST7:5, todos os demais apresentam 1 potencial sítio de O-glicosilação sendo que o clone PST7:7e8 apresenta dois sítios, sendo o clone mais glicosilado potencialmente.

A glândula de veneno sintetiza, estoca e secreta na forma aproximadamente 100-200 componentes de proteínas/peptídeos com diferentes estruturas e funções. O percurso da toxina do aparelho de Golgi ao lúmen do epitélio glandular é guiado por um peptídeo sinal que é muito conservado. A razão desta elevada conservação é que o peptídeo sinal de um determinado grupo de toxinas tem sempre a mesma função - dirigir a secreção da toxina através das membranas celulares sendo, portanto praticamente invariante (MATSUI et al, 2000;DESHIMARU et al., 1996). A maioria das proteínas secretadas são glicosiladas e como os clones obtidos apresentaram sítios potenciais de $\mathrm{N}$-glicosilação e a giroxina purificada do veneno de cascavel Crotalus durissus terrificus é glicosilada, apresentando $3,8 \%$ de açúcares totais (CAMILLO et al, 2005), é acertado expressar a giroxina em célula de mamífero.

$\mathrm{Na}$ figura 21, alinhando-se os clones GPS:2e5 e GPS:3e4 com outras seqüências de precursores de serino proteases pudemos comprovar uma 
elevada conservação na região do peptídeo sinal. Devido a essa conservação mesmo entre espécies diferentes, foi possivel desenhar um primer sense para a região do peptídeo sinal denominado primer peptídeo sinal P.S, que com o primer antisense T7 foi possível amplificar seqüências precursoras similares ao clone B2.1 conforme o esquema mostrado na figura 11 .

Existem algumas diferenças de nucleotídeos que podem resultar ou não em mudanças de aminoácidos; alguns exemplos foram analisados e estão mostrados nas figuras 21 (CDNA) e 30 (aminoácidos):

- $\quad$ nucleotídeo 18 (A) da seqüência de serino protease de Bothrops jararacussu (AY251282.1) não resulta na mudança do $6^{\circ}$ aminoácido pois GTA e GTG codificam para Valina ( $V$ ),

- o nucleotídeo 19 (A) da seqüência HS 120 de Bothrops jararaca (AB178323.1) resulta em mudança de no 70 aminoácido, pois ATA codifica para Isoleucina (I) e nas outras seqüências CTA codifica para Leucina (L),

- $\quad$ nucleotídeo 31 (G) da seqüência precursor de Ancrod de Agkistrodon rhodostoma resulta na mudança do $11^{\circ}$ aminoácido, pois GTG codifica para Valina ( $V$ ) e nas outras seqüências CTG codifica para Leucina ( $L$ ).

O sítio de clivagem entre o peptídeo sinal (18 aminoácidos) e a toxina secretada na glândula pôde ser predito comparando-se seqüências de precursores com seqüências de toxinas maduras (figura 30) e utilizando-se o programa SignalP 3.0 (figura 31). No caso das SVSPs após o peptídeo sinal existe um pró-peptídeo para manter a toxina inativa em relação à sua atividade enzimática na forma de um zimógeno. Após a extração do veneno o zimogênio é convertido em toxina com atividade proteolítica pela clivagem do pró-peptídeo. Esse pró-peptídeo apresenta seis aminoácidos que são clivados pós-secreção por proteólise parcial do N-terminal (figura 30).

Com a finalidade de verificar as diferenças entre nucleotídeos e aminoácidos entre as toxinas maduras dos clones B2.1, GPS:2e5, GPS:3e4, PST7:3, PST7:4, PST7:5 e PST7:7e8, foi realizado o alinhamento em nucleotídeos e aminoácidos (figura 29).

Conforme já comentado anteriormente, existem muitas diferenças de nucleotídeos que ocasionam em mudanças de aminoácidos, mas existem também muitas diferenças de nucleotídeos que não afetam a proteína, são as denominadas "mutações silenciosas". O clone PST7:7e8 apresentou muitas diferenças em relação aos demais clones e pudemos observar também que 
existem algumas seqũências de nucleotídeos dos clones B2.1, GPS:2e5 e PST7: 3 que diferem dos clones GPS:3e4, PST7:4 e PST7:5. Assim, podemos relacionar as seguintes diferenças:

- a seqüência GGT nos clones B2.1 e PST7:7e8 codifica para o aminoácido $\mathrm{G}$ (40 aminoácido do clone B2.1 e $28^{\circ}$ aminoácido do clone PST7:7e8) sendo que os outros clones apresentam a seqüência GGA codificando para o mesmo aminoácido $\mathrm{G}$ ( $\mathrm{n}^{\circ} 28$ ).

- a seqüência GGT no clone B2.1 pode ter sido ocasionada pelo primer GYR SE, pois na figura 8 podemos observar que essa região GTC ATT GGA GGT faz parte do primer GYR SE, sendo introduzida essa diferença no nucleotídeo $n^{\circ} 12(T)$ do clone B2.1.

-a seqüência GGT ( $T$ de no 84 ) no clone PST7:7e8 codifica para o aminoácido $G$ ( $n^{\circ} 28$ ) e nos demais clones (com exceção do clone B2.1) a seqüência é GGA (A de no ${ }^{84}$ ) que também codifica para o mesmo aminoácido G (no 28). Como o código genético é degenerado (mais de uma trinca de códon pode codificar para o mesmo aminoácido) a mutação do código genético, no caso $A$ por $T$ não implicou em mudança de aminoácido e consequentemente da proteína. No entanto, de acordo com KIMCHI-SAFARTY et al, 2006 mutações silenciosas nem sempre são "silenciosas", pois mutações no código genético que são traduzidas na mesma seqüência de aminoácido, podem ter implicações, na taxa de transcrição e tradução e por conseguinte no dobramento da proteína e na regulação de sua função.

Os três grupos formados pelos clones de CDNA B2.1, PST7:3 e GPS:2e5 (I), PST7:4, GPS:3e4 e PST7:5 (II) e o clone mais divergente PST7:7e8 (III) (figura 28) está de acordo com o dendrograma das toxinas maduras codificadas pelos clones de cDNA (figura 32), sendo o clone PST7:5 devido ao erro de edição na remoção dos íntrons, faltando o éxon 4 não foi alinhada. A seqüência da região da toxina madura de SVSPs mais similar com cada clone (tabela 24) é concordante com o agrupamento, bilineobina para o primeiro grupo, stejnobin para o segundo grupo e serino protease CL5 para o clone PST7:7e8 que é o mais divergente. A stejnobin é uma serino protease da Trimeresurus stejnegeri com ação trombina-símile, mas não ativa outros fatores da coagulação como plasminogênio, protrombina e fator $X$ (Zhang et al, 1998), a bilineobina é uma enzima trombina-símile da Agkistrodon bilineatus que converte o fibrinogênio em fibrina, liberando os fibrinopeptídeos 
A $\alpha$ e B $\beta$, (KOMORI et al, 1993). O grupo I (formado pelos clones B2.1, PST7:3 e GPS:2e5) apresentou o mais alto escore de similaridade com bilineobina e sua ação é similar à da giroxina. A seqüência da serino protease CL5 da Trimeresurus stejnegeri está depositada no banco de dados mas os dados sobre a atividade dessa serino protease não está descrito na literatura.

O veneno da serpente Crotalus durissus terrificus apresenta 2 serino proteases descritas: a giroxina (BARRABIN et al.;1978; SEKI et al.,1980) e uma enzima trombina símile (RAW et al.,1986 e RUIZ DE TORRENT et al, 2007). Os clones do grupo I podem ser giroxina ou isoformas de giroxina devido a possíveis erros introduzidos pela Taq DNA polimerase, o grupo II podem ser isoformas de giroxina também por possiveis erros introduzidos pela Taq DNA polimerase ou ser a trombina-símile e o clone PST7:7e8 é o mais divergente de todos os outros grupos.

Com relação à região $3^{\prime}$ UTR podemos observar na figura 29 que o clone B2.1 tem uma 3' UTR mais curta, mas a análise deste clone, utilizandose o programa Spidey, com um gene da batroxobin mostrou que o clone B2.1 apresenta sinal de poliadenilação e cauda de poli $A$, sendo que o cDNA de batroxibin apresenta um $3^{\prime}$ UTR mais curto que os clones PST7s conforme mostrados na tabela 21 e figura 27.

Outras seqüências de serino proteases de serpente têm 3'UTR de tamanho similar. Entretanto, podemos verificar que no clone PST7:3 existem dois sinais potenciais de poliadenilação ( $5^{\prime}$-AATAAA- $\left.3^{\prime}\right)$, um na posição $929 \mathrm{pb}$ e o outro na posição $1380 \mathrm{pb}$. O sinal real de poliadenilação do clone PST7:3 está imediatamente antes da cauda de poliadenina (posição $1380 \mathrm{pb}$ ). Entretanto, é possível que ambos os sítios possam ser reconhecidos e clivados para se acrescentar uma cauda de poliadeninas criado uma 3' UTR mais curta ou mais longa dependendo do sítio reconhecido. O sinal de poliadenilação do clone B2.1 (posição $857 \mathrm{pb}$ ) alinha com o sítio potencial de poliadenilação do clone PST7:3 (posição 929pb). Os clones PST7:4, PST7:5, e PST7:7e8 apresentam a seqüência 5'-AAGAAA- 3'nas respectivas posições $1381 \mathrm{pb}$, $1235 \mathrm{pb}$ e $1372 \mathrm{pb}$ que alinha com o sinal de poliadenilação do clone B2.1. O clone B2.1 pode representar o mesmo clone PST7:3 e as três diferenças de aminoácidos encontradas no clone B2.1 em relação ao clone PST7:3 observado na figura 29, podem ter sido introduzidas durante o $P C R$, pois na clonagem do clone B2.1 foi utilizada uma Taq DNA polimerase recombinante 
de baixa fidelidade e na clonagem do clone PST7:3 foi utilizada uma Taq DNA polimerase Platinum (com maior fidelidade). Nesse caso, a presença de dois sinais de poliadenilação do clone PST7:3 resultariam em dois transcritos com diferentes 3'UTRs, sendo que o menor transcrito pode corresponder a B2.1. Por outro lado pode existir na glândula de veneno um mRNA com 3'UTR curta ou um mRNA com 3'UTR longa contendo 2 sinais de poliadenilação.

No ensaio de PCR para obter os clones PST7s (figura 22), os mRNAs de 3'UTRs curtos podem estar presentes na banda imediatamente abaixo da baixa excisada do gel, sendo que a banda clonada deve conter somente mRNAs de 3 'UTRs longos.

A possibilidade de existirem mRNAs com 3' ÚTRs de diferentes tamanhos baseia-se em CHARBONNIER et al, 2002, que isolou por RT-PCR uma forma longa de miogenina de Xenopus laevis (XmyogU2) que apresentava dois sinais de poliadenilação (5'AATAAA 3') na posição 1054 e $1328 \mathrm{pb}$, enquanto que a seqüência do clone XmyogU1 apresentava somente o segundo sinal de poliadenilação na posição $1328 \mathrm{pb}$. Esse resultado sugere que a presença de pelo menos dois sinais de poliadenilação do clone XmyogU2 resulta em dois transcritos com diferentes tamanhos de $3^{\prime}$ UTRs.

A organização éxon/íntron de diversas proteases da familia de serino proteases mostra que estas podem ser divididas em diversas subfamílias. Em relação à organização éxon/íntron o gene de batroxobin (figura 27) apresenta a mesma estrutura de 5 éxons e 4 íntrons dos genes de calicreína e Tripsina. Novos íntrons surgem na região da protease para os genes de outras serino proteases: um novo íntron para o ativador tissular de plasminogênio e para os genes de urokinases. Dois novos íntrons para o gene do quimiotripsinogênio e 3 novos íntrons para os genes das elastases. Já os íntrons para a trombina fator IX e fator do complemento B são completamente diferentes das outras serino proteases evidenciando que se tratam de famílias com diferentes origens gênicas.

A organização do CDNA de todas as seqüências obtidas pode ser feita tomando como referência a batroxobin. $O$ gene de batroxobin tem uma extensão de $\sim 8 \mathrm{kbp}$ e contém 5 éxons intervalados por 4 íntrons. A extremidade $5^{\prime}$ do gene contém fração da região $5^{\prime} U T R$, a seqüência consenso para o TATA-box e o sítio do início da transcrição ( +1 ATG). O primeiro éxon compreende grande parte da região da seqüência codificante do peptídeo sinal 
e corresponde a 240 pares de bases (pb). O éxon 2 tem um comprimento de $151 \mathrm{pb}$ e codifica para o fragmento final do peptídeo sinal, para o pró-peptídeo e para a região $\mathrm{N}$-terminal da toxina madura. $O$ éxon 3 contém $260 \mathrm{pb}$ e codifica parte da toxina madura. $O$ éxon 4 também codifica um fragmento da toxina madura e tem $134 \mathrm{pb}$. O éxon 5 com $728 \mathrm{pb}$ compreende o C-terminal da toxina madura o stop códon (TGA) a região $3^{\prime} U T R$ com 360 pb e o sinal de poliadenilação. O cDNA de batroxobin se ajusta adequadamente aos éxons presentes na seqüência genômica do gene de Batroxobin. Estes cinco éxons são interrompidos por quatro íntrons, sendo que o íntron 1 tem $2,5 \mathrm{kpb}$, o íntron 2 tem 1,7 kpb, o intron 3 tem 1,8 kpb e o intron 4 tem 0,35 kpb. As regiões que dividem o éxon/íntron concordam com a regra GT/AG. Como a toxina madura é codificada separadamente pelos éxons de 2 a 5 , os resíduos do sítio catalítico da batroxobin também estão distribuídos em éxons separados. His-41 (éxon 2), Asp-86 (éxon 3) e Ser-178 (éxon 5) (ITOH et al, 1988).

O tipo e a localização dos íntrons 2,3 e 4 do gene da batroxobin são muito semelhantes aos encontrados nos genes de tripsina e de calicreina, sendo o íntron 2 do tipo II, o intron 3 do tipo I e o íntron 3 do tipo O. Estes resultados indicam que o gene da batroxobin é um membro da família gênica das tripsinas/calicreínas. Como muitas das proteases dos venenos das serpentes apresentam seletividade por substrato e ações proteolíticas similares à ação da trombina sobre o fibrinogênio essas enzimas de serpente são comumente chamadas de trombina-símile. Mas a organização genômica da batroxobin deixa claro que o seu gene não pertence à família gênica da trombina e sim à família das tripsinas/calicreína. Como as glândulas de veneno das serpentes podem ter origem nas glândulas submaxilares que são ricas em calicreínas é hipoteticamente possivel que as serinoproteases do veneno de serpentes derivem de genes da família das calicreínas glandulares (ITOH et al, 1987, ITOH et al, 1988).

Ao analisar as seqüências de cDNA de sete clones giroxina simile de Crotalus durissus terrificus (B2.1, GPS:2e5, GPS:3e4, PST7:3, PST7:4, PST7:5 e PST7:7e8) com o gene de batroxobin foi possivel identificar a mesma organização de exóns e estimar qual região do cDNA é codificada pelo éxon específico (figura 27 e tabela 21 ). 
O clone PST7:5 não apresenta o éxon 4 sendo que a hipótese mais provável é que ocorreu um erro de edição na remoção dos íntrons 3 e 4 (splicing alternativo) eliminando o éxon 4. A edição alternativa através de diferentes combinações de remoção dos íntrons é um mecanismo usado para ativar ou reprimir a expressão de um gene. É importante ressaltar que no éxon 4 não está presente os resíduos do sítio catalítico podendo gerar uma proteína funcional, mas o fato do éxon 5 quando diretamente ligado em seqüência ao exon 3 faz surgir um stop códon que quando incorporado no mRNA a transcrição da proteína será interrompida prematuramente, gerando um polipeptídeo truncado. Em alguns casos dois éxons que carregam diferentes moléculas de RNA podem sofrer a remoção dos íntrons ao mesmo tempo, gerando uma única molécula de RNA. Esse processo é conhecido como trans-splicing, sendo um processo que ocorre em quase todos os mRNAs de tripanossomas (WATSON et al, 2004). De acordo com DOSSIN \& SCHENKMAN, 2005 a RNA polimerase II de tripanossomas, transcreve um longo mRNA policistrônico que não apresenta $5^{\circ} \mathrm{CAP}$, mas é processado através de transsplicing e poliadenilação para formar o mRNA maduro.

Com a finalidade de se predizer uma eventual função para os clones obtidos, a seqüência correspondente à toxina madura destes clones foram organizados em um dendrograma funcional (figura 33) alinhados com diversas toxina cuja atividade hemotóxica é bem descrita. As seqüências puderam ser divididos em 4 grupos, ficando claro que todas as toxinas atuam na cascata de coagulação, porém algumas apresentam funções extras, com caracterísiticas intermediárias entre um grupo e outro.

No grupo I estão os ativadores de fator V, VLFVA-ativador de Fator V de Vipera lebetina (SIIGUR et al, 1999) e RVV-V $\alpha$ de Vipera Russeli ; enzima que ativa o fator $V$ na mesma extremidade que a $\alpha$-trombina (TOKUNAGA et al, 1988).

No grupo II estão os ativadores de plasminogênio. Duas enzimas (TSVPA e Haly-PA) confirmaram apresentar a função de ativador de plasminogênio e facilitar a solubilização dos monômeros de fibrina. Os membros ativadores de cininogênio e ativador de plasminogênio são pouco ou totalmente não glicosilados (WANG et al, 2001).

No grupo III estão as fibrinogenases sendo que algumas toxinas têm sido caracterizadas por também serem capazes de clivar o cininogênio, 
produzindo bradicina (cinina) responsável por induzir hipotensão. Segundo CASTRO et al, 2004, KN-BJ produz bradicinina e curiosamente, elegaxobin de Trimeresurus elegans é a única SVSP citada até o momento capaz de liberar Lys-bradicinina do plasma. Além disso a elegaxobin atua como heterólogo da C3 convertase que cliva independentemente C 3 humano e inicia a cascata do sistema complemento.

Essas enzimas em geral não clivam o fibrinogênio, mas algumas clivam a cadeia $B \beta$ ou ambas as cadeias $A \alpha$ e $B \beta$ do fibrinogênio: halystase e calobin clivam ambas as cadeias $A \alpha$ e $B \beta$ do fibrinogênio (WANG et al, 2001), palabin deve apresentar uma função similar por estar no mesmo ramo que a halystase e calobin sendo aqui denominado o grupo IIIb. As enzimas que se encontram no ramo IIIa como catroxase I, elegaxobin, mucrofibrase I são capazes de clivar a cadeia A $\alpha$ do fibrinogênio.

As trombinas símiles mais conhecidas que convertem o fibrinogênio em fibrina como: crotalase, ancrod (comercialmente vendida como $\operatorname{Arvin}^{\circledR}$ da Calloselasma rhodostoma), acutobin, batroxobin (Defibrase ${ }^{\circledR}$ da Bothrops moojeni), bothrombin, se encontrram no grupo IVa- enzimas que atuam sobre o fibrinogênio, sendo caracterizadas por liberarem o fibrinopeptídeo $A \alpha$ e serem altamente glicosiladas (WANG et al, 2001).

A giroxina isolada do veneno de cascavel Crotalus durissus terrificus (CAMILLO et al, 2001), o análogo de giroxina isolada do veneno de Lachesis muta muta (DA SILVA et al, 1989; MAGALHÃES et al, 1993) e a crotalase (MASSOVA et al, 1997), são descritos por liberaram preferencialmente o fibrinopeptídeo A $\alpha$. É importante ressaltar que as toxinas pertencentes ao grupo IVa podem apresentar outras funções ainda não bem descritas. A seqüência da giroxina símile B2.1 e dos clones análogos (PST7:3, GPS:2e5, PST7:4,GPS:3e4) isoladas do veneno de Crotalus durissus terrificus se encontram todas nesse grupo.

No grupo IVb se encontram as toxinas CPI enzyme-2 e a ativadora de proteína $C(A C C-C)$ que além de atuarem sobre o fibrinogênio apresentam algumas outras características: A CPI enzyme-2 aumenta a permeabilidade vascular e a ACC-C é uma toxina de serpente capaz de ativar a proteína $C$ da coagulação, sendo que a seqüência $\mathrm{PST7:7e8}$ se encontra nesse grupo se mostrando mais divergente no alinhamento em relação as demais seqüências isoladas na biblioteca de CDNA. É interessante notar que VITAL-BRAZII (1980) 
relata 0 isolamento da delta toxina, uma toxina do veneno de Crotalus durissus terrificus, capaz de alterar a permeabilidade capilar e causar grande hemoconcentração.

Segundo SHIMOKAWA \& TAKAHASHI, 1997 a CPI enzyme-2 cliva a cadeia $B \beta$ do fibrinogênio, liberando peptídeos que aumentam a permeabilidade capilar. $O$ ativador de proteína $C$ (ACC-C) de $A$. c. contortrix é comercializada como $\operatorname{Protac}^{\circledR}$ (STOCKER et al, 1987). A proteína C é uma glicoproteína vitamina $K$ dependente que circula no sangue como um zimógeno de serino protease. É ativada pela trombina na superfície endotelial na presença de trombomodulina. Uma vez que a proteina $C$ é ativada, degrada - fator Va e apresenta uma ação anticoagulante (SERRANO \& MAROUN, 2005). Algumas serino proteases trombina-símiles são capazes de ativar a proteína C como a toxina ativadora de proteína C (ACC-C) sendo descrita por STOCKER et al 1987, que demonstraram que a ativação da proteína $C$ pela toxina ACC-C de A. c. contortrix degrada os fatores Va e VIIIa apresentando uma ação anticoagulante.

O dendrograma funcional mostra que os clones B2.1, GPS:2e5, GPS:3e4, PST7:3, PST7:4 e PST7:5 são homólogos a enzimas coagulantes que clivam o fibrinogênio liberando o fibrinopeptídeo A $\alpha$ e o clone PST7:7e8 é mais homólogo a CPI enzyme-2 e a toxina ativadora de proteína $C$.

As diferenças nas atividades biológicas dessas serino proteases do veneno de serpentes estão provavelmente relacionadas a diferenças na composição dos aminoácidos compondo sítios específicos, ainda que a estrutura terciária geral seja similar.

O modelo tridimensional da giroxina fol comparado com os modelos cristalográficos de TSV-PA (1bqy), DAV-PA (1op2) e tripsina bovina (2ptc) (figura 35).

As diferenças encontradas na região do C-terminal das SVSP em relação à tripsina é uma importante característica, pois a região do C-terminal nos domínios de protease apresenta uma importante função nessa classe de enzimas que desenvolveram uma grande variedade de substratos específicos e funções biológicas importantes. Essa região é freqüentemente codificada por um único éxon que apresenta a maioria dos resíduos que formam a superfície de contato no sítio ativo para os resíduos P1- P3 do substrato, assim como 
domínios responsáveis pela modulação da atividade catalítica (KREM et al, 1999).

Na figura 35 é possível observar que o sítio potencial de glicosilação na asparagina 85 da giroxina codificada pelo clone B2.1 se encontra muito distante do sítio ativo, ao contrário do que acontece nas glicosilações das serino proteases AaV-SPI e AaV-SPII de Agkistrodon acutus que se encontra muito próximo, resultando em alterações na atividade amidolítica (ZHU et al, 2005).

A figura 36 mostra que a tríade catalítica da giroxina se sobrepõe muito bem com relação a da tripsina (2ptc), ou seja, a giroxina B2.1 deve ter atividade proteolítica similar a tripsina.

$\mathrm{Na}$ figura 37, é possível comparar o modelo tridimensional da giroxina e crotalase com o modelo cristalográfico da $\alpha$ - trombina humana (1c50). Segundo MASSOVA et al, 1996, o exosítio de ligação ao fibrinogênio na trombina é formado por duas alças (Phe-34 aLeu-41 e Lys-70 a Glu-80). A segunda alça é composta por resíduos básicos na crotalase (Arg-58, Lys 64, Arg 67 e Arg 68) e na $\alpha$-trombina (Arg 67, Lys 70, Arg 73, Arg 75, Arg 77 e Lys 81 ) representado de roxo. No entanto na crotalase é encontrada uma outra alça na qual se encontra um exositio alternativo de ligação ao fibrinogênio, ausente na trombina, que é formada pela adição de cinco aminóacidos básicos (Arg 46, Lys 71, Lys 73, Arg 93 e Lys 96) representado em rosa. As posições 71, 73 e 96 encontradas na crotalase são bastante conservadas em algumas serino proteases, sendo os resíduos todos básicos. Podemos observar a presença dos mesmos aminoácidos na estrutura tridimensional da giroxina, sugerindo a existência deste exosítio alternativo. Funcionalmente este sítio alternativo poderia estar relacionado com a neurotoxicidade da giroxina, como o rolamento em barril. A numeração dos aminoácidos corresponde à posição na seqüência primária da toxina. A cadeia pesada da $\alpha$-trombina corresponde aos aminoácidos 16 a 247.

Com relação às serino proteases do veneno de serpente, há um interesse no seu uso para tratamento clínico de infarto do miocárdio, tromboses em veias profundas, pancadas ou embolia pulmonar (MARKLAND,1988). Existem 4 enzimas semelhantes à trombina comercialmente disponiveis já descritas anteriormente: ancrod (Arvin ${ }^{\circledR}$ da Calloselasma rhodostoma); batroxobin (Defibrase ${ }^{\circledR}$ da Bothrops moojeni); 
crotalase (de Crotalus atrox) e uma enzima trombina-símile ativador de proteína C (Protac ${ }^{\circledR}$ da Agkistrodon contortrix). Segundo THOMAZINI-SANTOS et al.,2001, há uma nova aplicação em fase experimental referente a utilização da giroxina isolada do veneno de Crotalus durissus terrificus como "cola de fibrina".

No entanto o uso de enzimas trombinas-símiles tem sido limitado por: disponibilidade de veneno de serpentes, reações imunológicas em pacientes, contaminações em preparações comerciais de proteínas oriundas do veneno que não estão de acordo com as boas práticas de fabricação. Isso justifica a produção de uma toxina recombinante em célula de mamífero, uma vez que se trabalha em condições estéreis e o produto formado será livre de contaminações por vírus, bactérias e fungos.

A produção de enzimas trombina-símile recombinantes é uma maneira de contornar esses problemas (KINI, 2006; YANG et al, 2002; WARKENTIN, 1998, STOCKER et al, 1987).

As variadas aplicações destas enzimas justificam as tentativas relativas a sistemas de expressão para se obter SVSPs recombinantes. Até o momento, foram usados vetores de expressão em bactéria E.coli (MAEDA et al.1991; HAHN et al.1996; PAN et al.,1999; HUNG \& CHIOU,2000; GUO et al.,2001: ZHA et al.2003; YANG et al.,2003, YUAN et al.,2004); baculovírus (PARK et al.,1998). As proteínas recombinantes foram obtidas com rendimento aquém dos desejáveis e/ou não apresentaram as atividades biológicas ou apresentaram baixa atividade quando comparadas com as toxinas nativas.

As proteínas recombinantes presentes em corpúsculos de inclusão, geralmente após sua solubilização e renaturação são obtidas com pouca atividade biológica e de difícil renaturação. Assim, sistemas de expressão com células de mamíferos poderiam ser mais adequados, pois estão presentes as vias de glicosilação e de modificações pós-traducionais mais similares às que ocorrem no epitélio glandular da serpente quando comparado com sistemas de expressão em células de leveduras.

O clone B2.1 foi utilizado para subclonagens em vetores de expressão para célula de mamífero ( $p E D$ ), capaz de dirigir a secreção da toxina para o meio de cultura por intermédio de um peptídeo sinal de IgKappa murina 
(obtido do vetor pSecTag2 Hygro A) (figuras 38,39 ,44 e 47). Para os passos de subclonagem veja a figura 12 .

Em um estudo prévio de citotoxicidade em células $\mathrm{CHO}-\mathrm{K} 1 \mathrm{dhfr}^{+}$com giroxina purificada obtivemos a $\mathrm{CT}_{50}$ de $200 \mu \mathrm{g} / \mathrm{mL}$, o que permite supor que não teríamos problemas de toxicidade da enzima recombinante sobre o sistema de expressão (a concentração esperada é ao redor de $100 \mu \mathrm{g} / \mathrm{ml}$ ) (HASHIZUME \& CAMILLO, 2005).

Após a seleção dos clones de células CHO-DXB11 transfectadas com vetor pED-giroxina, cada cultura celular foi submetida a uma amplificação com aumento gradual da concentração do MTX, selcionando os clones por 6 meses.

Segundo KAUFFMAN, 1990, a expressão transiente nas células COS-1 resulta em $1 \mu \mathrm{g}$ de proteína $/ 10^{6}$ células. $O$ rendimento da proteína secretada no meio de cultura geralmente é de $0,3-1 \mu \mathrm{g} / \mathrm{mL}$ sendo rápida a caracterização dos clones (48-72 horas). Na transfecção realizada nas células CHO-DXB11 dhfr' a expressão é estável, podendo detectar altos níveis de expressão da proteína. É possível detectar a proteína recombinante após a amplificação por MTX na concentração de 20nM, no entanto os clones selecionados por MTX, não foi possível detectar a expressão em até 1280nM. No ensaio de RT-PCR de acordo com os nossos resultados verificamos que o mRNA giroxina-dhfr não foi produzido na forma dicistrônica estando separado em 2 mensageiros: para a giroxina e para o dhfr. Portanto ao selecionarmos os clones fortemente para dhfr podemos favorecer as células que perderam a capacidade de formar o mRNA giroxina ou esse mensageiro pode ser degradado rapidamente.

Segundo YUK et al, 2002 durante o processo de expressão estável de uma proteína problemas podem ocorrer pois a expressão estável de proteinas recombinantes em célula de mamífero é muitas vezes um processo demorado devido ao fato de somente uma pequena porcentagem de células transfectadas expressarem uma quantidade suficiente de proteína. Por isso o número de clones a serem selecionados e amplificados é necessariamente muito grande. O próprio processo de amplificação pode causar a morte do clone.

Com o intuito de verificar se o plasmídeo pED-Giro se encontra integrado no genoma da célula, podemos observar na figura 49 que os primers Igk SE/DHFR AS (A) amplificaram a seqüência IgK-DHFR presente no extrato 
do clone 6 (CHO-DXB11 transfectada com o plasmídeo pED-Giro) mostrando que o plasmídeo estava integrado no genoma da célula. No entanto, os primers IgK SE/GYR AS1 (B) além de amplificar a seqüência IgK-Giro, também está amplificando alguma seqüência similar no genoma da célula CHO-DXB11 $d f h r$, esta seqüência homóloga pode prejudicar a expresão do produto recombinante nessa célula hospedeira.

Com o intuito de verificar a presença de um único mRNA giroxina-dhfr, foi realizado um ensaio de RT-PCR de acordo com o esquema mostrado na figura 14. Ao utilizar os primers GYR SE/DHFR AS (figura 51-A) não verificamos a presença de bandas, mostrando que não há a formação de um único mRNA. O par de primers GYR SE/AS 1 (figura 51-C) além de amplificar o mRNA giroxina está amplificando alguma seqüência similar presente na célula controle negativo $\mathrm{CHO}-\mathrm{K} 1 d f h r^{+}$. O mRNA dhfr foi amplificado com os primers DHFR SE/AS (figura 51-B), sendo a banda mais intensa do que o mRNA giroxina.

$O$ esquema do segundo ensaio de RT-PCR é mostrado na figura 14. Ao utilizar os primers IgK SE/DHFR AS (figura 53-D) confirmou o ensaio anterior, não há a formação de um único mRNA giroxina-dhfr, ao utilizar o par de primers IgK-SE/ GYR AS 1 (figura 53-F), observamos a presença do mRNA giroxina. O mRNA dhfr foi amplificado com o par de primers DHFR SE/AS (figura 53-E) apresentando uma intensidade maior do que a giroxina. $O$ fato de ter inserido a região $3^{\prime}$ UTR, sinal de poliadenilação e cauda de poli A do CDNA da giroxina do clone B2.1 pode ter contribuído para que a região 3 'UTR do mRNA fosse modificada ocorrendo a sua clivagem e logo em seguida a adição de uma cauda de poli A, pois é sabido que a Poliadenilation binding protein cliva a região $3^{\prime}$ UTR logo após encontrar um sinal de poiliadenilação antes de acrescentar a cauda de adeninas (LEWIN, 1994).

O mRNA IgK-giroxina por estar com uma intensidade bem menor que - mRNA dhfr, parece que se encontra instável. Isso sugere que o mRNA da giroxina, seja rapidamente degradado em comparação ao mRNA de $d h f r$, pois como o dicístron giroxina-dhfr se encontra clivado e a célula precisa aumentar a produção do dhfr para sobreviver, há a necessidade de altas quantidade do mRNA dhfr. Segundo KAUFFMAN, 1990, é recomendado remover as 
seqüências 3 'não traduzidas do CDNA, pois essas seqüências podem levar a uma instabilidade do mRNA.

Com a finalidade de validar a construção do vetor pED-Giro B2.1 a despeito do mRNA que deveria de ser dicistrônico se encontra separado em dois mensageiros (giroxina e $d h f r$ ) e verificar se o mRNA giroxina é traduzido, obtendo-se a expressão da giroxina B2.1 em curto prazo, foi realizada a transfecção transiente do plasmídeo pED-Giro e pSecTag Igk-Giro em outra linhagem celular COS-7.

O clone pED-Giro foi expresso e secretado no meio de cultura com sucesso nas células COS-7 sendo a giroxina recombinante detectada pelo soro anticrotálico do Instituto Butantan, apresentando as mesmas duas bandas e estando na mesma altura de 33kDa que a giroxina purificada do veneno, indicando que a giroxina recombinante deve estar glicosilada da mesma forma (figura 55). Assim, ainda que se formem 2 mensageiros giroxina e dhfr, o mRNA de giroxina é estável o suficiente para acumular proteína recombinante em um sistema transiente. Podemos perceber que apesar do vetor pSecTag2HygroA ser um vetor comercial, a expressão do clone pSecTag Igk-Giro foi muito menor com relação a expressão obtida com o clone pED-Giro que apresenta o peptídeo sinal IgK do vetor pSecTag2Hygro $A$, mas um promotor mais forte, sendo que o vetor pED é descrito por KAUFFMAN, 2000 por ser um vetor eficiente para transfecção transiente e também pode ser utilizada para transfecção permanente. Esse vetor pED tem sido descrito por SOARES et al, 2000; PERONI et al, 2002; CHURA-CHAMBI et al, 2004 por obterem bons niveis de expressão de prolactina, hormônio tireotrófico e endostatina em uma transfeç̧ão permanente em célula CHO-DXB11.

$\mathrm{Na}$ figura 56-B podemos observar que a amostra com precipitado do lisado da célula sonicada coS-7 transfectada com pED-Giro (canaleta 7) apresentou uma banda muito mais intensa que a amostra sobrenadante do lisado da célula sonicada coS-7 transfectada com o plasmídeo pED-Giro (canaleta 5) pois está 10x mais concentrada que a fração solúvel. Entretanto, a precipitação da proteína recombinante pode ser explicada pelo fato de que em muitos casos, a translocação da proteína é limitada. Estudos com expressão de diversas proteínas mostraram que as proteínas que transitam no compartimento de secreção apresentam uma taxa limitada de secreção no 
transporte do retículo endoplasmático para o complexo de Golgi (KAUFMAN, 1992).

É conhecido que a expressão de uma proteina heteróloga de secreção, a partir de um gene transfectado introduzido em uma célula, pode ser limitada devido ao transporte ineficiente do retículo endoplasmático para o Complexo de Golgi. Uma grande variedade de etapas pós-traducionais, que são necessárias para a maturação apropriada e a atividade biológica da proteína, podem ficar saturadas se a expressão da proteina específica é aumentada (KAUFMAN, 1992).

Além disso a giroxina B2.1 recombinante foi eficientemente expressa e secretada para o meio de cultura, sendo purificada do meio de cultura $24 \mathrm{~h}$ após a transfecção com o plasmídeo pED-Giro, apresentando as mesmas duas bandas e na mesma alltura de 33kDa que a giroxina purificada do veneno conforme mostra a figura 56-C. A giroxina recombinante purificada do meio de cultura apresentou uma elevada atividade esterásica de acordo com a figura 57.

A obtenção da giroxina recombinante foi obtida com sucesso pois mostramos que é possivel expressar uma serino protease de serpente em um sistema de expressão transiente em célula de mamífero no meio de cultura com atividade biológica. Este é um sistema de expressão muito interessante para se caracterizar outras toxinas e proteínas com funções ainda desconhecidas facilitando o processo de purificação com um elevado grau de pureza pela secreção direta no meio de cultura. 


\section{6-CONCLUSÃO}

Neste trabalho foi possivel:

- Determinar a seqüência de nucleotídeos da giroxina madura do veneno da cascavel Crotalus durissus terrificus que ainda não havia sido descrita e depositar no banco de dados GenBank (AY954040).

- Comparar a similaridade da seqüência primária da giroxina com outras serino proteases de venenos de serpentes (SVSPS), identificando a tríade catalítica HDS típica de serino proteases, as posições das cisteínas e os potenciais sítios de glicosilação.

- Determinar as seqüências de nucleotídeos de 6 novas serino proteases comparando-as com seqüências SVSPs presentes em banco de dados.

- Identificar as regiões de 5 éxons nos clones em comparação com o gene de batroxobin. No entanto verificamos que no clone PST7:5 o éxon 4 está ausente possivelmente decorrente de um erro de edição na remoção dos introns.

- Realizar um dendrograma funcional com a giroxina e as variantes identificadas, comparando-as com outras serino proteases de venenos de serpentes.

- Realizar um modelo tridimensional de homologia da giroxina, identificando o sítio catalítico, a conformação do C-terminal, o sítio potencial de glicosilação e a comparação com o modelo tridimensional da crotalase, com os cristalográficos da TSV-PA (1bqy), AaV-SP-I (10p0), DAV-PA (10p2), $\alpha-$ trombina humama (2c50) e da tripsina bovina (2ptc).

- Construir um vetor dicistrônico pED-Giro e transfectar em células CHODXB11 ahfr". No entanto essa construção foi lábel, pois observamos a presença do mRNA giroxina separado do mRNA dhfr.

- Construir um vetor de expressão eucariótica pED-Giro com o peptídeo sinal Igk que possibilitou expressar a giroxina recombinante em célula de mamífero cos-7 e obter a sua secreção para o meio de cultura.

Purificar a giroxina recombinante do meio de cultura e demonstrar a sua atividade esterásica. 


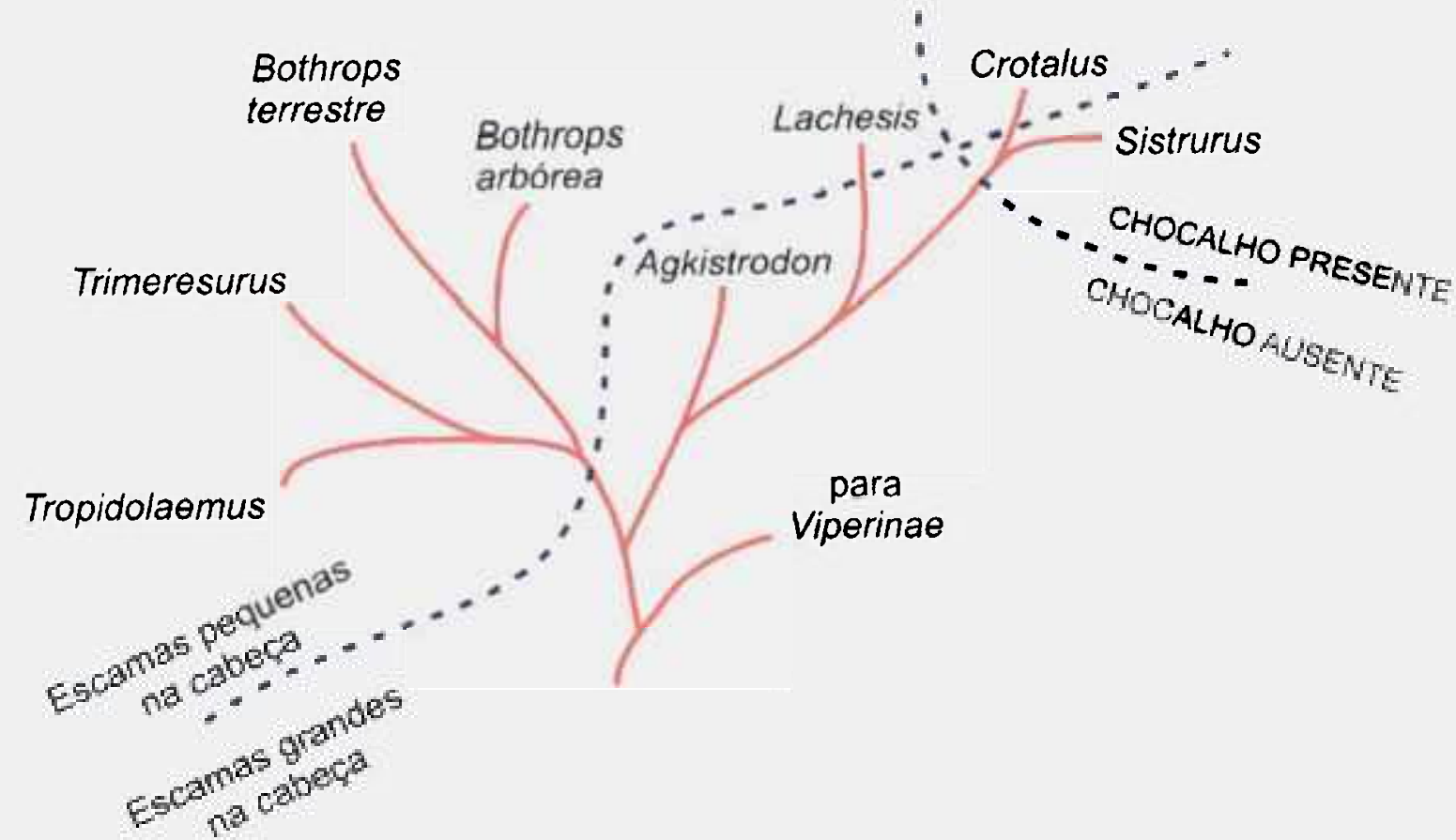

Figura 1: Filogenia sugerida para a subfamília Crotalinae (BRATTSTROM, 1964).
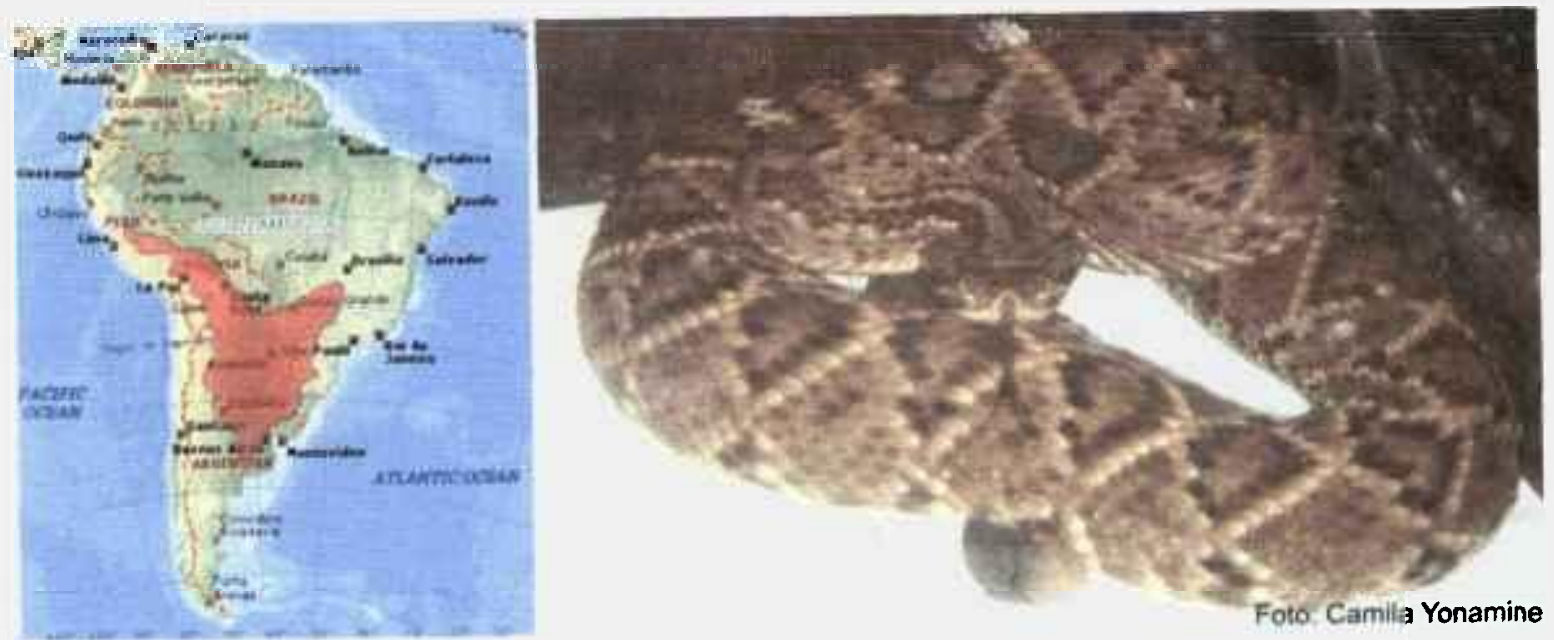

Figura 2: Cascavel apresentando o chocalho (guizo) e a distribuição geográfica Crotalus durissus terrificus mostrada em vermelho. 


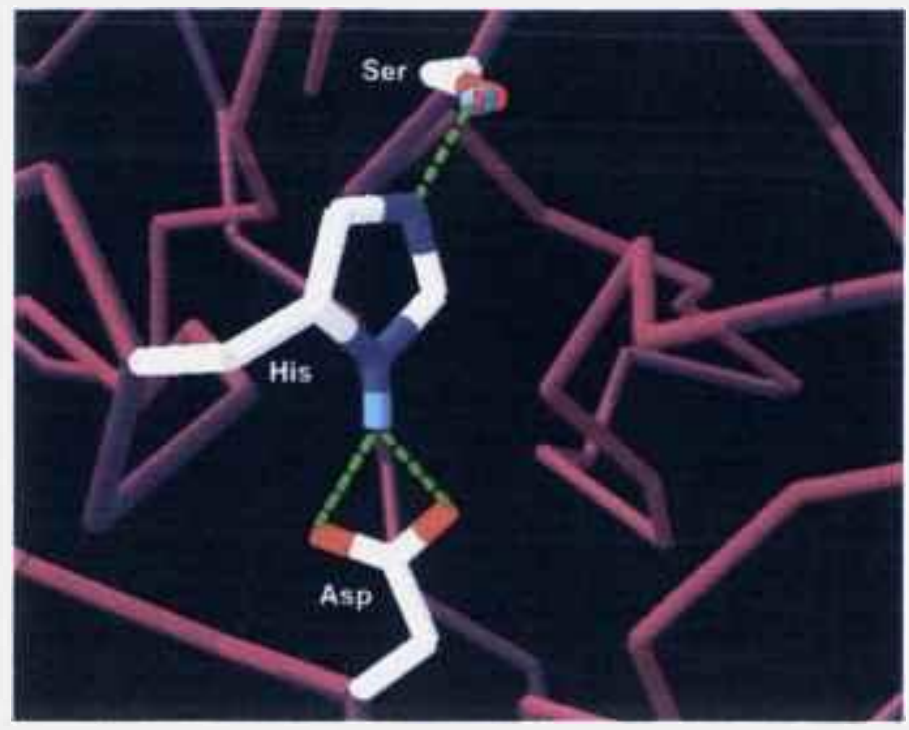

Figura 3: Sítio ativo de uma serino protease.

Compartilhamento de pontes de hidrogênio mostradas em verde entre a tríade catalítica de uma protease da família S1.

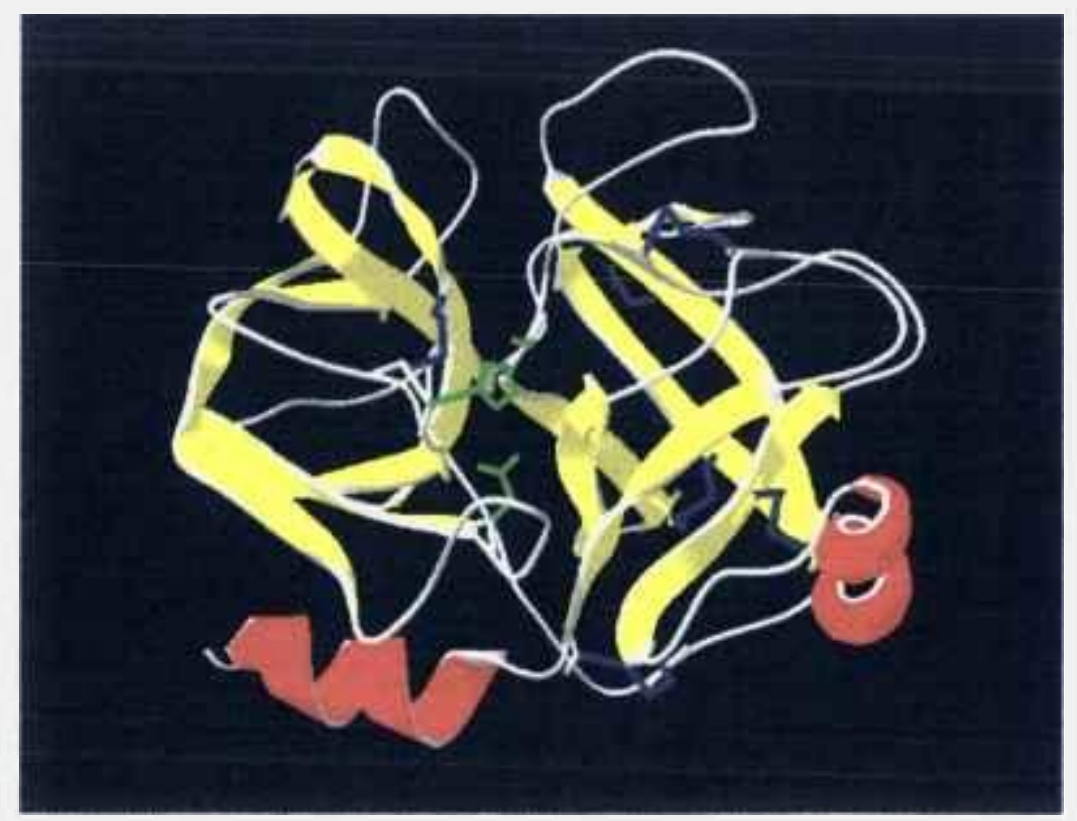

Figura 4: Estrutura tridimensional da tripsina.

Em amarelo são mostradas as folhas $\beta$-pregueadas que compõem os dois domínios em barril- $\beta$. Em vermelho as $\alpha$-hélices, em azul as pontes dissulfetos e em verde os aminoácidos da triade catalítica. 


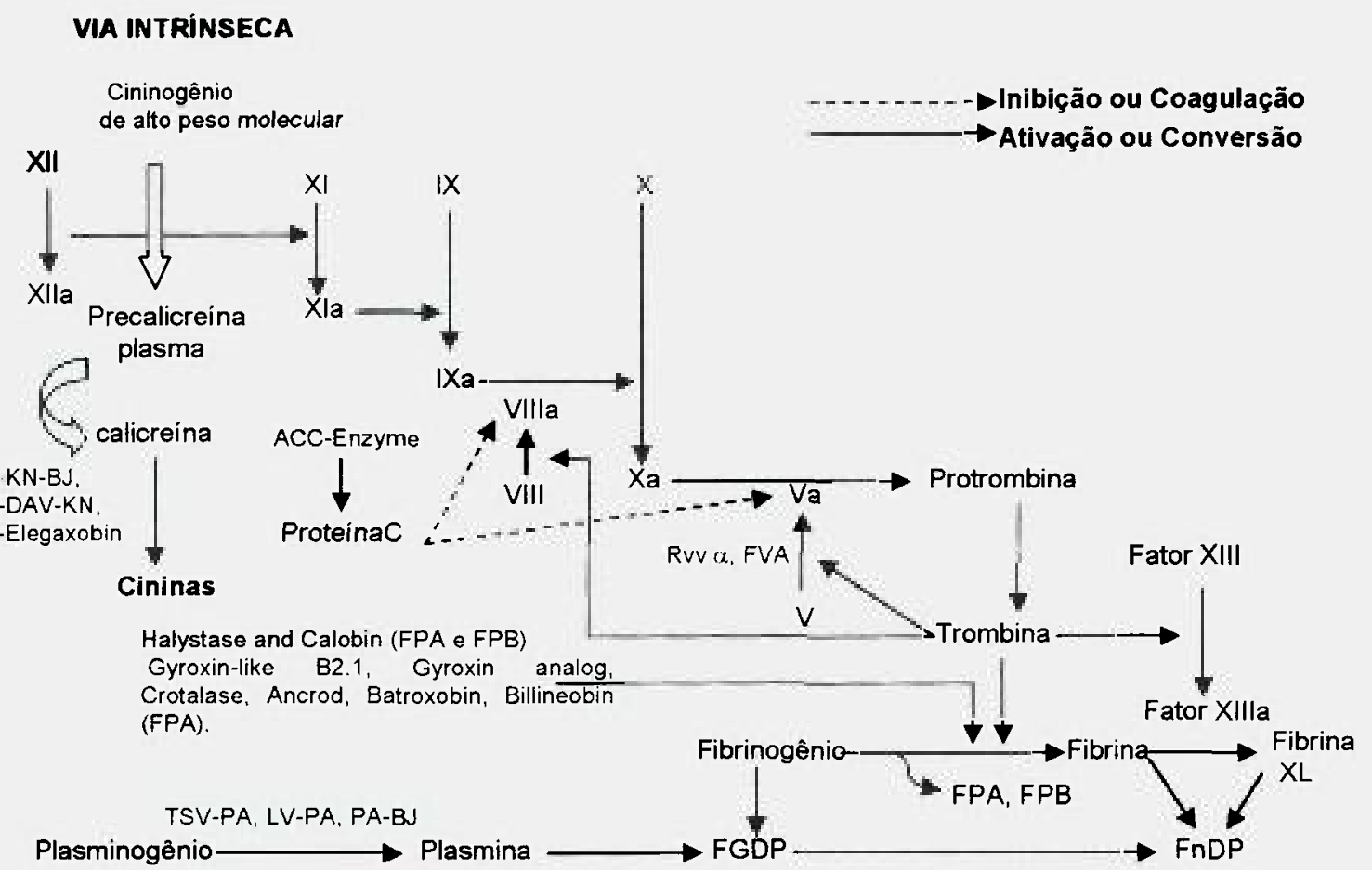

Figura 5: Algumas serino proteases do veneno de serpentes agindo na cascata de coagulação. (Baseado em MARKLAND, 1998).

FGDP: Fibrinogen degradation products; FNDP: Fibrin degradation products; FPA: Fibrinopeptide A; FPB: Fibrinopeptide B.

KN-BJ, Bothrops jararaca (013069- Serrano et al,1998); Dav-KN, Agkistrodon acutus (Q9I8X0- Wang et al, 2001); Elegaxobin-1, Trimeresurus elegans (P84788Oyama et al, 2002); ACC-C Protein C activator; Agkistrodon contortrix contortrix (P09872- McMullen et al, 1989); RVV-V $\alpha$ Vipera russelli proteinase, Daboia russelli siamensis (P18964 - Tokunaga et al..1988); FVA Factor V-activating enzyme, Vipera lebetina (Q9PT41- Siigur et al, 1999), Halystase, Agkistrodon halys blomhoffii (P81176- Matsui et al. 1998); Calobin, Agkistrodon caliginosus (Q91053 - Hahn et al. 1996), Gyroxin-like B2.1, Crotalus durissus terrificus (Q58G94); Gyroxin analog, Lachesis muta muta (P33589 - Magalhães et al,1993); Crotalase, Crotalus adamanteus (Henschen-Edman et al,1999); Ancrod, Agkistrodon rhodostoma (P26324 - Burkhart et al,1992); Batroxobin, Bothrops atrox (P04971 - Itoh et al, 1987); Bilineobin, Agkistrodon bilineatus (Q9PSN3- Nikai et al, 1995);TSV-PA, Trimeresurus stejnegeri (Q91516 - Zhang et al, 1995); LV-PA, Lachesis muta muta (P84036-Sanchez et al, 2000); PA-BJ, Bothrops jararaca (P81824-Serrano et al, 1995). 
1 10

20 30

Giroxina (Kaiser) VIGGDECNINEHNE LVALYEY HESF LO-GSGiroxina (Simpson, UVGEDECNINGHRSIVAIEPLAFY-E-CYGSW

Figura 6: Seqüências do $\mathrm{N}$-terminal da giroxina de C.d.terrificus (DA SILVA et al, 1989). 


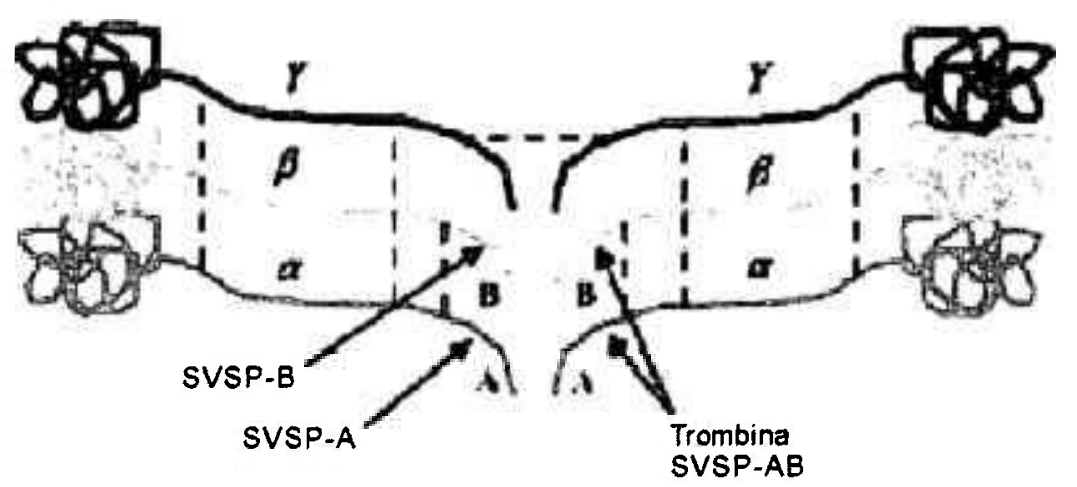

Figura 7: Pontos de clivagem da molécula do fibrinogênio.

A figura mostra as cadeias $A \alpha$ e $B \beta$ clivada pela trombina e as cadeias $A \alpha$ e/ou $B \beta$ clivadas pelas serino proteases do veneno de serpentes (SVSPS). CASTRO et al, 2004 modificado. 
$\begin{array}{lllllllll}\text { N-terminal de Giroxina de C.d.terrificus } & \text { V } & \text { I } & \text { G } & \text { G } & \text { D } & \text { E } & \text { C } & \text { N }\end{array}$

(Simpson) (Da Silva et al, 1989).

$$
\begin{aligned}
& \text { GT_AT_GG_GG_GA_GA_TG_AA } \\
& \text { Calobin } 1 \text { GTCATTGGAgGtGATGAATGtAAC } \\
& \text { Salmobin } 2 \text { GTCATTGGAGGTGATGAATGTAAC } \\
& \text { Trimumbin } 3 \text { GTCATTGGAGGTGATGAATGTAAC } \\
& \text { Mucrofibrase-2 } 4 \text { GTCATTGGAGGTGATGAATGTAAC } \\
& \text { Ancrod } 5 \text { GTCATTGGAGgTGATGAATGTAAC } \\
& \text { Stejnobin } 6 \text { GTCATTGGAGGTGATGAATGTAAT } \\
& \text { Catroxase I } 7 \text { ATCATCGGAGGTGATGAATGTAAC } \\
& \text { Primer GYR SE } 5 \text { '-GTCATTGGAGgTGATGAATGTAAC-3' }
\end{aligned}
$$

Figura 8: Definição do primer GYR-SE.

1- Calobin de Agkistrodon ussuriensis (AUU32937); 2- Salmobin de Gloydius halys (Af056033); 3-Trimubin de Trimeresurus mucrosquamatus (TMU31417); 4Mucrofibrase-2 de Trimeresurus mucrosquamatus (X83222); 5-Ancrod de Calloselasma rhodostoma (L07308); 6- Stejnobin de Trimeresurus stejnegeri (AF545576); 7-Catroxase I de Crotalus atrox (AF227153.1). 


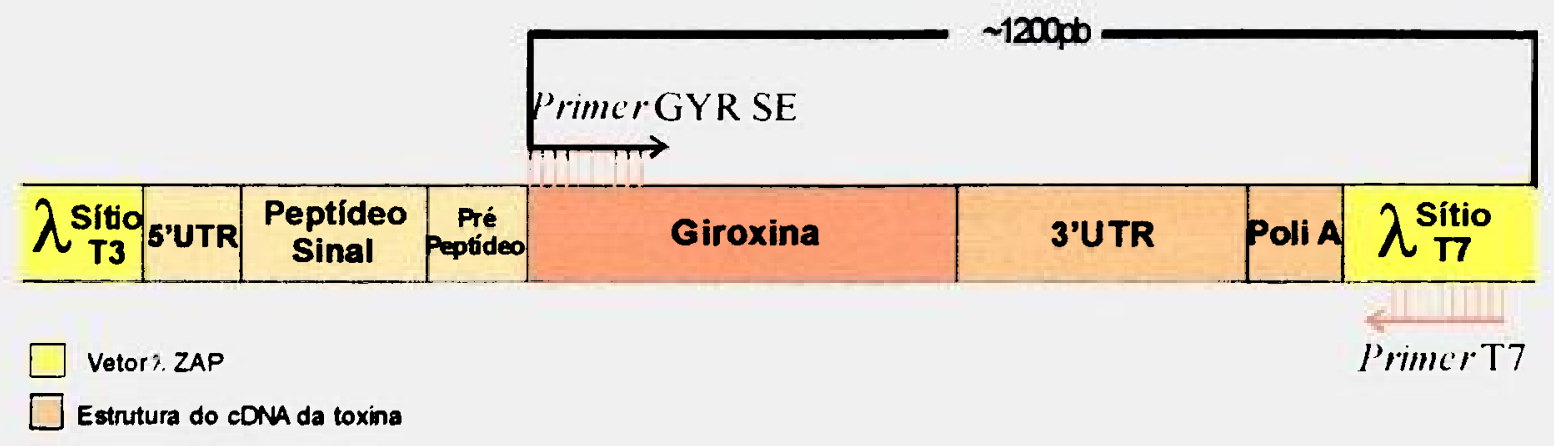

Figura 9: Esquema do PCR para obter o clone B2.1.

$\mathrm{Na}$ reação foi utilizada a biblioteca de CDNA de Crotalus durissus terrificus com os primers GYR SE e T7.

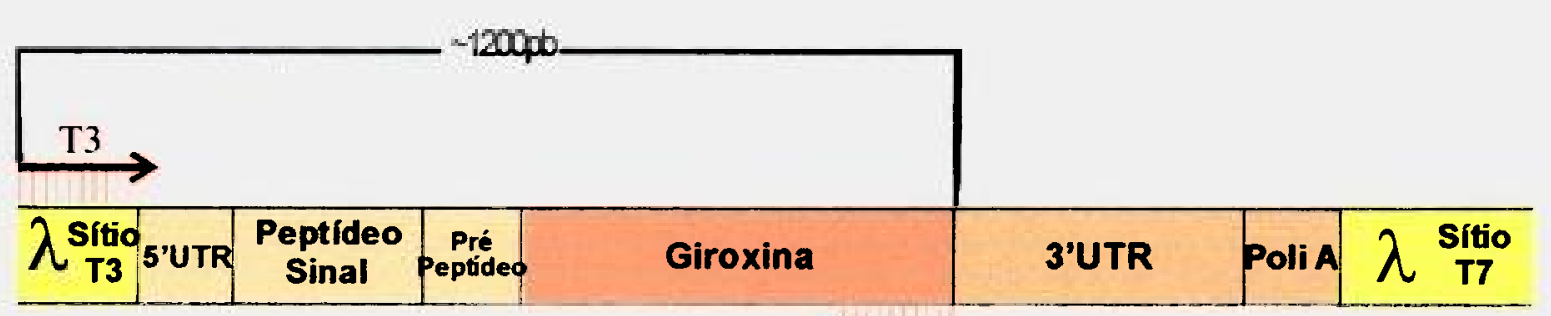

Vetor X. ZAP

GYR ASI

$\square$ Estrutura do cDNA da toxina

Figura 10: Esquema do PCR para obter os clones GPSs.

$\mathrm{Na}$ reação foi utilizada a biblioteca de CDNA de Crotalus durissus terrificus com os primers T3 e GYR AS1.

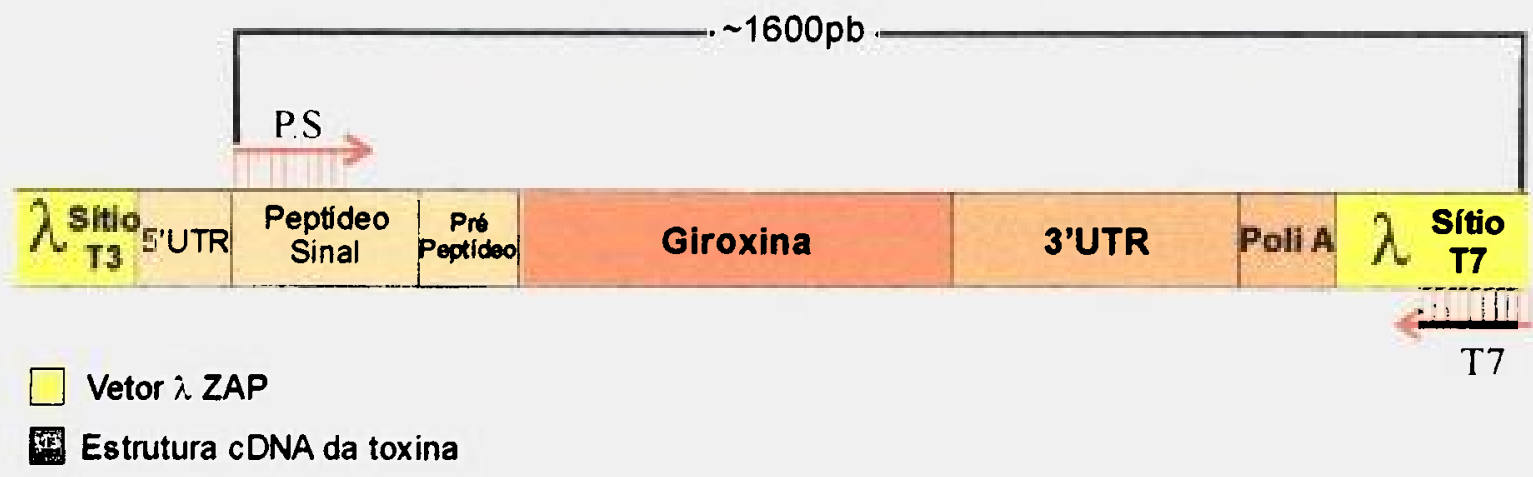

Figura 11: Esquema do PCR para obter os clones PST7s.

Na reação foi utilizada a biblioteca de CDNA de Crotalus durissus terrificus com os primers P.S e T7. 
$\sim 2100 \mathrm{pb}(\mathrm{A})$

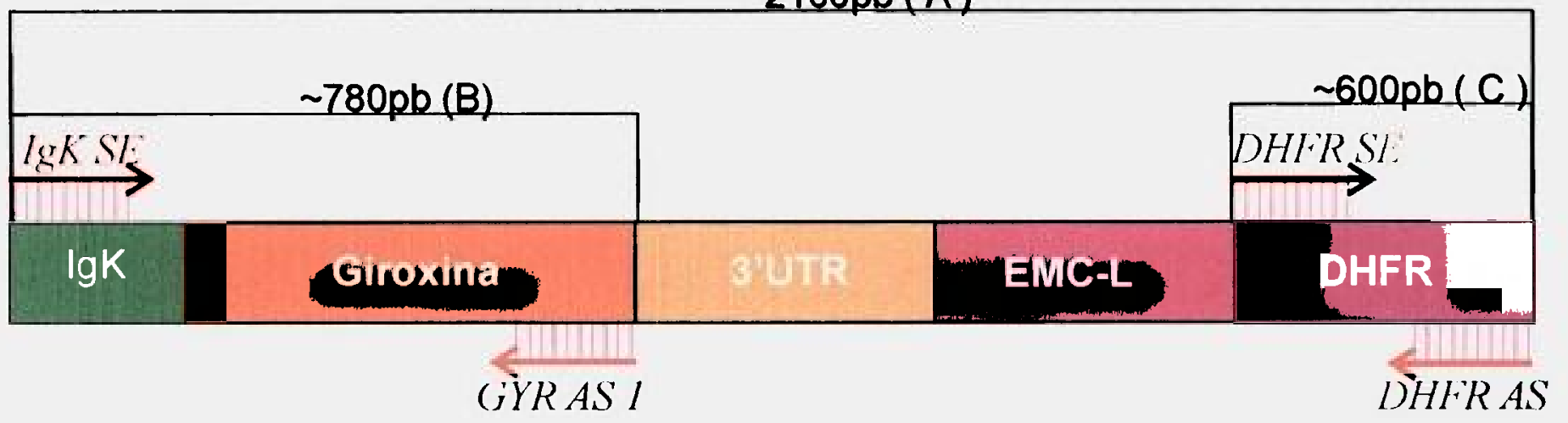

Figura 13: Deteç̧ão do vetor pED-Giro integrado ao genoma da célula CHO-DXB11 Região de complementaridade dos primers IgK SE, GYR AS1, DHFR SE, DHFR AS presentes no vetor pEDGiro. 


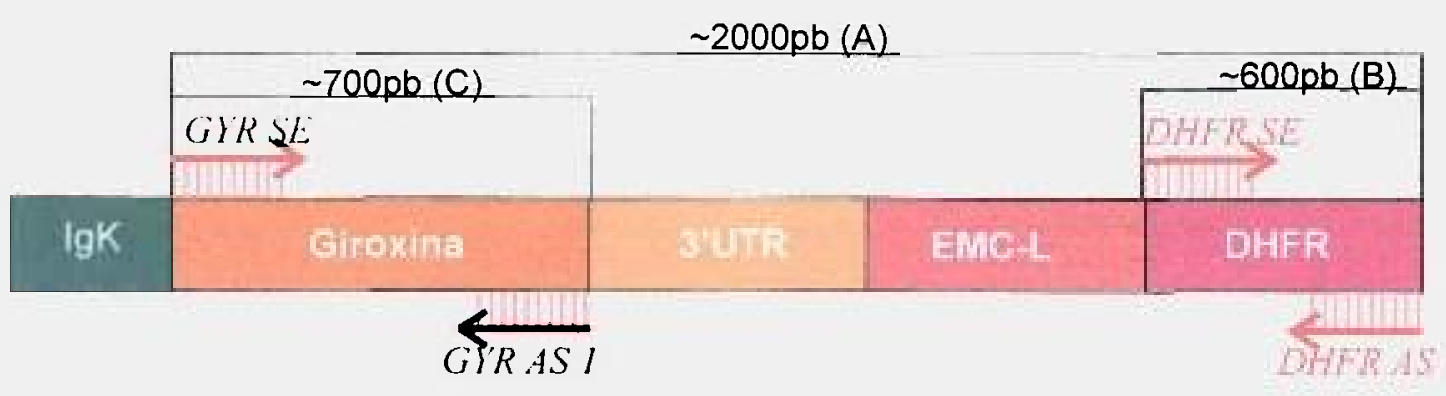

$\sim 2100 \mathrm{pb}(\mathrm{D})$

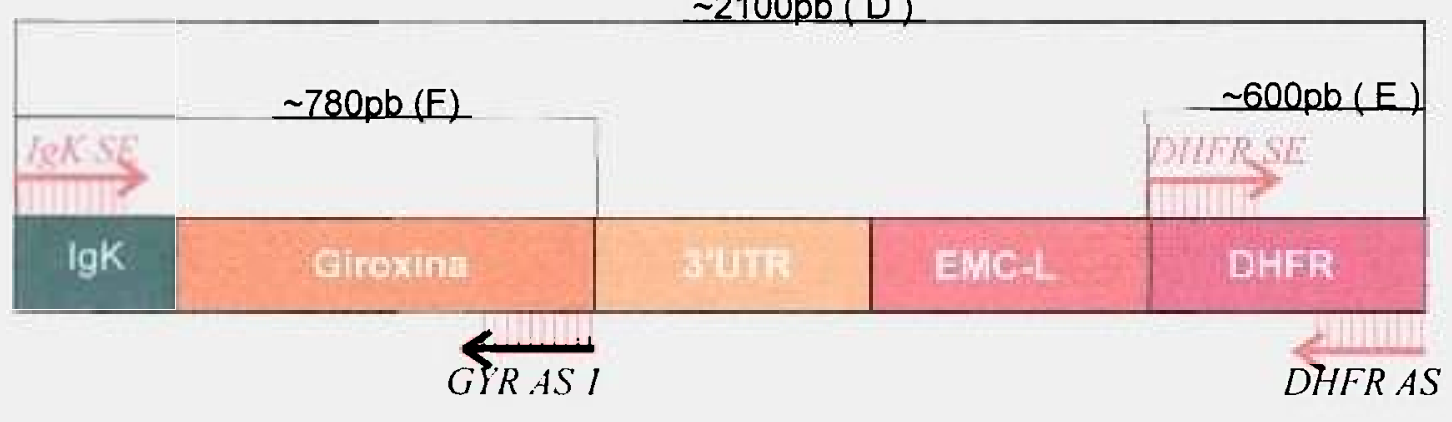

\begin{tabular}{|c|c|c|c|}
\hline Amostras & $\begin{array}{c}\text { Primer (sintese da } \\
\text { primeira fita de } \\
\text { CDNA) }\end{array}$ & $\begin{array}{l}\text { Primer (sintese da } \\
\text { segunda fita de }\end{array}$ & Ensaio de RT-PCR \\
\hline 4,8 e CHO-K1 dhfr ${ }^{+}$ & DHFR AS & GYR SE/DHFR AS e & mRNA da fusão giro-DHFR (A) \\
\hline 4,8 e $\mathrm{CHO}-\mathrm{K} 1 d h f r^{+}$ & GYR AS & GYR SE/AS & mRNA de Giro (C) \\
\hline $\begin{array}{c}4,6,4+20 \mathrm{nM} \\
6+320 \mathrm{nM} \\
\text { CHO-DXB11 dhfr }\end{array}$ & DHFR AS & $\begin{array}{c}\text { IgK SE/DHFR AS e } \\
\text { DHFR SE/ AS }\end{array}$ & $\begin{array}{l}\text { mRNA da Fusão Giro DHFR (D) } \\
\text { mRNA de DHFR (E) }\end{array}$ \\
\hline $\begin{array}{c}4,6,4+20 \mathrm{nM} \\
6+320 \mathrm{nM} \\
\mathrm{CHO}-\mathrm{D} \times \mathrm{B} 11 \mathrm{dhfr} \\
\end{array}$ & GYR AS & IgK SE/ GYR AS & mRNA giro (F) \\
\hline
\end{tabular}

Figura 14: Detecção do mRNA expresso pela célula CHO-DXB11x pED-Giro.

Região de complementaridade dos primers IgK SE, GYR SE, GYR AS1, DHFR SE, DHFR AS presentes no vetor $P E D$-Giro utilizados nas reações $A, B, C, D, E$ e F.

Comissio:: 


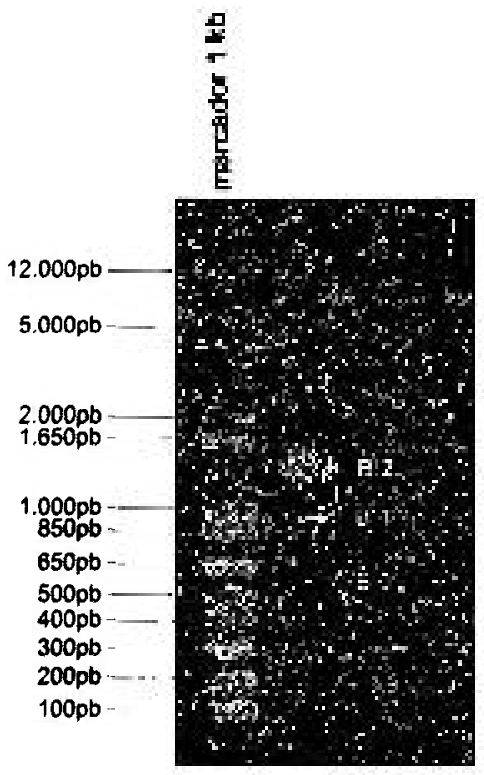

Figura 15: Amplificação da biblioteca de CDNA da glândula de veneno da cascavel Crotalus durissus terrificus por PCR.

Análise em gel de agarose $1,5 \%$ correspondente a amplificação da biblioteca de CDNA com um primer sense específico para a giroxina madura GYR SE e o primer T7.

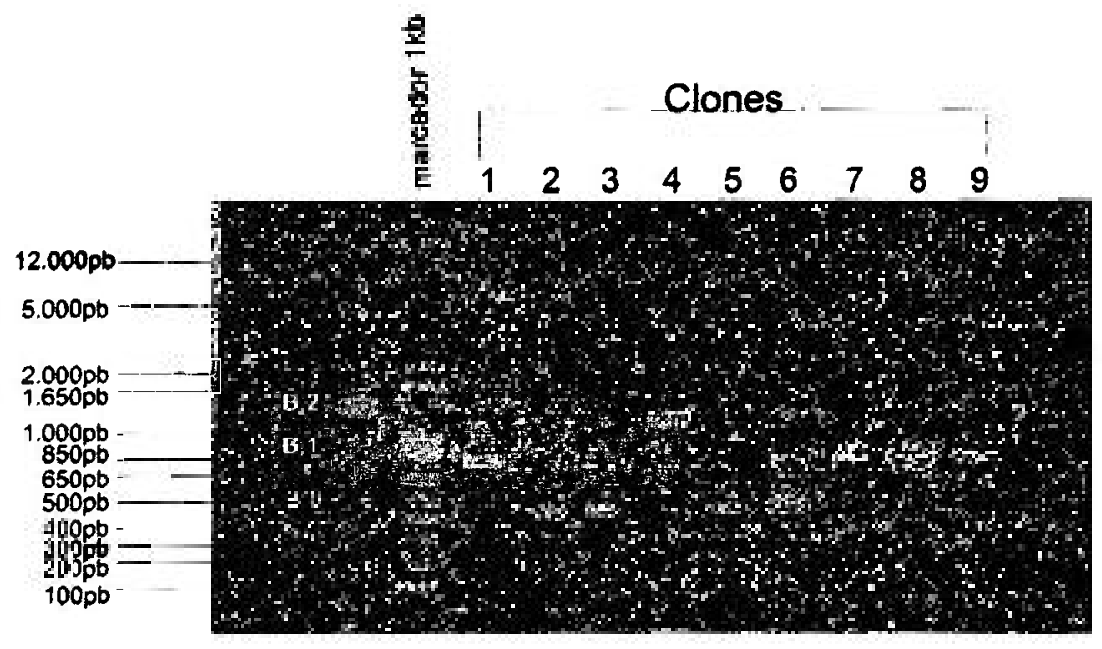

Figura 16: Seleção do clone B2.1 por PCR.

Análise em gel de agarose 1,5\% correspondente a amplificação dos clones recombinantes (1 a 9) utilizando-se os primers M13 sense e antisense. $\mathrm{Na}$ primeira canaleta indicado $\mathrm{B} 2, \mathrm{~B} 1$ e $\mathrm{BO}$ corresponde a 3 bandas do produto de amplificação da biblioteca de CDNA com os primers GYR SE e T7. 


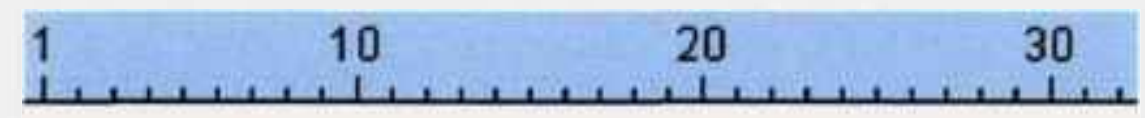

B2.1-Giroxina 1) VIGGDECNINERNELVAIFEN SQSF IC-GGT Giroxina (Simpson) 2) VIGGDECNINEHNFIVAIYEYW SESFIC-GCGiroxina (Kaiser) 3)VVGGDECNINGHRSIVAIF FYAFY-F- GYGGW

Figura 17: Comparação dos 30 primeiros aminoácidos do clone de giroxina B2.1 com as seqüências $\mathrm{N}$-terminais da giroxina isolada do veneno de Crotalus durissus terrificus.

1-B2.1 Giroxina; 2- Giroxina (Simpson) (DA SILVA et al, 1989); 3-Giroxina (Kaiser) (DA SILVA et al, 1989). 


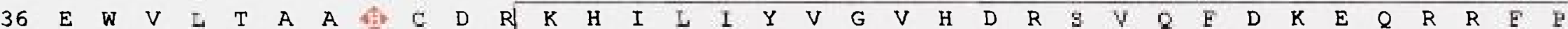
106 GAATGGGTGCTCACTGCTGCACACTGCGACAGGAAACATATCTTAATATACGTTGGTGTGCATGACCGAAGTGTGCAATTTGACAAGGAGCAGAGAAGATTCCCA

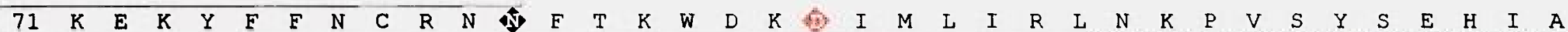
211 AAAGAGAAGTACTTTTTTAACTGTAGAAATAACTTTACCAAATGGGACAAGGACATCATGTTGATCAGGCTGAACAAACCTGTTAGTTACAGTGAACACATCGCA Scal, 221

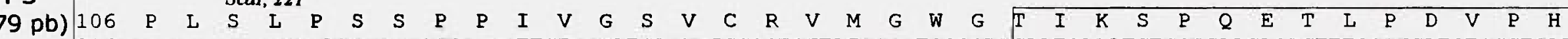
316 CCTCTCAGCTTGCCTTCCAGCCCTCCCATTGTGGGATCAGTTTGCCGTGTTATGGGATGGGGTACAATCAAATCTCCTCAAGAGACTTTGCCTGATGTCCCTCAT

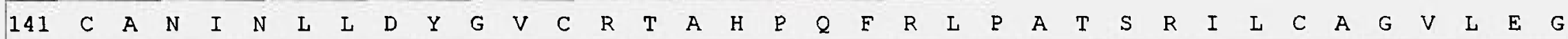
4

421 TGTGCTAACATTAACCTACTTGATTATGGAGTGTGTCGAACAGCTCACCCACAATTTCGGTTGCCAGCGACAAGCAGAATATTGTGTGCAGGTGTCCTGGAAGGA

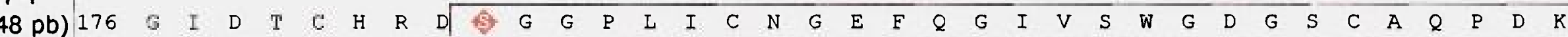
526 GGCATAGATACATGTCATCGTGACTCTGGGGGACCCCTCATCTGTAATGGAGAATTCCAGGGCATTGTATCTTGGGGAGACGGTTCTTGTGCCCAACCGGATAAG ECORI, 578
E

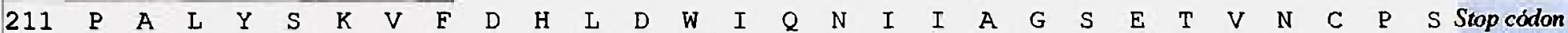

631 CCTGCCCTCTACAGCAAGGTCTTCGATCATCTTGACTGGATCCAGAACATTATTGCAGGAAGTGAAACTGTGAATTGCCCCTCGTGAaaa $t$ ttgaaaaagt ta BamHI,669

1736 agaggagaaatgtaacatattagtacatctcttctatatccctaaccatatccaactacattggaatatatccccaggcagtaagct tttttagactcaaata sinal de poliadenilação HindIII, 820

841 ggactgccttggagtaataaatactcaaatagtgctgchaaaaaaaaaaaa

$31 \mathrm{pb})$

Região codificante para toxina madura

Região 3'UTR

18: Organização do cDNA do clone B2.1 (895pb).

sssiveis éxons são: éxon $2(1-137 p b)$, éxon 3 (138-379pb), éxon 4 (380-548pb), éxon 5 (549-881pb).A região codificante para a madura está representada pela cor rosa claro e a região codificante para o 3 'UTR está representada pela cor roxa.A região cada em amarela na posição 857 pb representa o sítio de poliadenilação. O códon de parada (Stop códon-TGA) se encontra em co. A triade catalítica (HDS) se encontra em diamante vermelho e o sítio potencial de $\mathrm{N}$ - glicosilação se encontra em diamante 
1 ggcacgagctcgtgccgaactcggcacgagdgacgtaactctgtcagtgttccagattgttggccaccgagctgcttaatttgaccaagtaaagtgctgcttgat Sacl, II

106 caagaagtctctgcttgggttatctgattagactgacacggtatctcaagtttaagtaaaggactgggatcttacaggcaaacaacttgctgcacagagttgaag

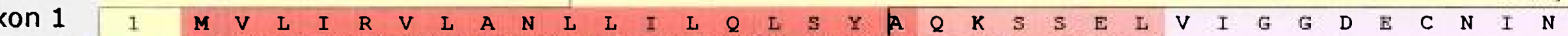
$264 \mathrm{pb}) 211$ ttATGGTGCTGATCAGAGTGCTAGCAAACCTTCTGATACTACAGCTTTCTTACGCACAAAAGTCTTCTGAGCTGGTCATTGGAGGAGATGAATGTAACATAAATG Stan +1 Nhel, 231
35 E Nhel, 231

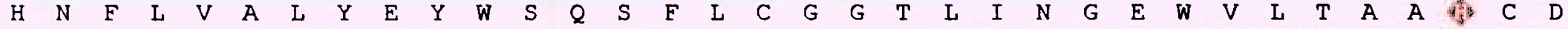

$\operatorname{con} 2$

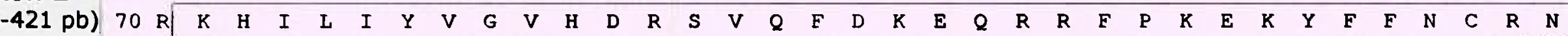

421 GqAAACATATCTTAATATACGTTGGTGTGCATGACCGAAGTGTGCAATTTGACAAGGAGCAGAGAAGATTCCCAAAAGAGAAGTACTTTTTTAACTGTAGAAATA

$\begin{array}{lllllllllllllllllllllllllllllllllllllllllll}105 & F & T & K & W & D & K & P & I & M & L & I & R & L & N & K & P & V & S & Y & S & E & H & I & A & P & L & S & L & P & S & S & P & P & I\end{array}$

con 3526 ACTTTACCAAATGGGACAAGGACATCATGTTGATCAGGCTGAACAAACCTGTTAGTTACAGTGAACACATCGCACCTCTCAGCTTGCCTTCCAGCCCTCCCATTG $-663 \mathrm{pb})$

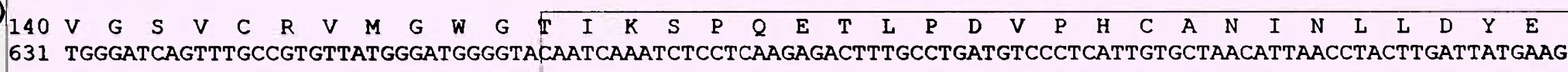

Kon $4 \quad 175$ V $-832 \mathrm{pb}) 736$ TGTGTCGAACAGCTCACCCACAATTTCGGTTGCCAGCGACAAGCAGAATATTGTGTGCAGGTGTCCTGGAAGGAGGCATAGATACATGTCATCGTGATTCTGGGG

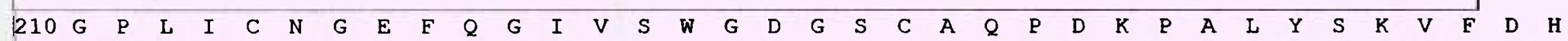
Kon 5841 GACCCCTCATCTGTAATGGAGAATTCGAGGGCATTGTATCTTGGGGAGACGGTTCTTGTGCCCAACCGGATAAGCCTGCCCTCTACAGCAAGGTCTTCGATCATC $-998 \mathrm{pb})$ ECORI, 862

$\begin{array}{lllllllllllllllllll}245 & \text { L } & \text { D } & \text { W } & \text { I } & Q & \text { N } & \text { I } & \text { I } & \text { A } & \text { G } & \text { S } & \text { E } & \text { T } & \text { V } & \text { N } & \text { C } & \text { P } & \text { S } \\ 946 & \text { TTGACTGGATCCA } & * \\ \text { BamHII. } 953 & \end{array}$

Região 5'UTR

Região codificante para o peptídeo sinal

Região codificante para o pró-peptideo

Região codificante para toxina madura

Região 3'UTR

ura 19: Organização do cDNA do clone GPS2e5 (998pb).

possíveis éxons são: éxon 1 (31-264pb), éxon 2 (265-421pb), éxon 3 (422-663pb), éxon 4 (664-832pb), éxon 5 (833-998pb).A região 5 'UTR : representada pela cor amarela, a região codificante para o peptídeo sinal está representada pela cor escuro, a região codificante para o prótídeo está representada pela cor rosa, a região codificante para a toxina madura está representada pela cor rosa claro e a região 3 ' UTR estáa esentada pela cor roxa. A região do Kozak está representado em negrito pela região -3 (G) e o início (start) +1 (A).O códon de início (ATG) estáa esentado em negrito. A tríade catalítica (HDS) se encontra em diamante vermelho e o sítio potencial de $\mathrm{N}$-glicosilação se encontra em diamante 
B2.1

Primer peptídeo sinal ALGTGCTGACAGAGTE

Sequência codificante para o peptídeo sinal

Sequência codificante para o propeptideo

Sequência codificante para o inicio da toxina madura

Nucleotideos que diferem entre as seqüências.

Figura 21: Região de hibridação do primer para o peptídeo sinal.

1) B2.1 de Crotalus durissus terrificus (AY954040); 2) GPS:2e5 de Crotalus durissus terrificus; 3) GPS:3e4 de Crotalus durissus terrificus; 4) Catroxase I de Crotalus atrox (AF227153.1);5) Serino protease 1 de Crotalus adamanteus (AJ251525.1); 6) Protrimubin de Trimeresurus mucrosquamatus (U31417); 7) Serino protease de Trimeresurus gramineu (D67083.1); 8) Serino protease de Bothrops jararacussu (AY251282.1); 9) HS 120 de Bothrops jararaca (AB178323.1); 10) Precursor de Ancrod de Agkistrodon rhodostoma (L07308.1). A da região de hibridação do primer corresponde aos nucleotídeos 1 a 18 do inicio do peptídeo sinal. 


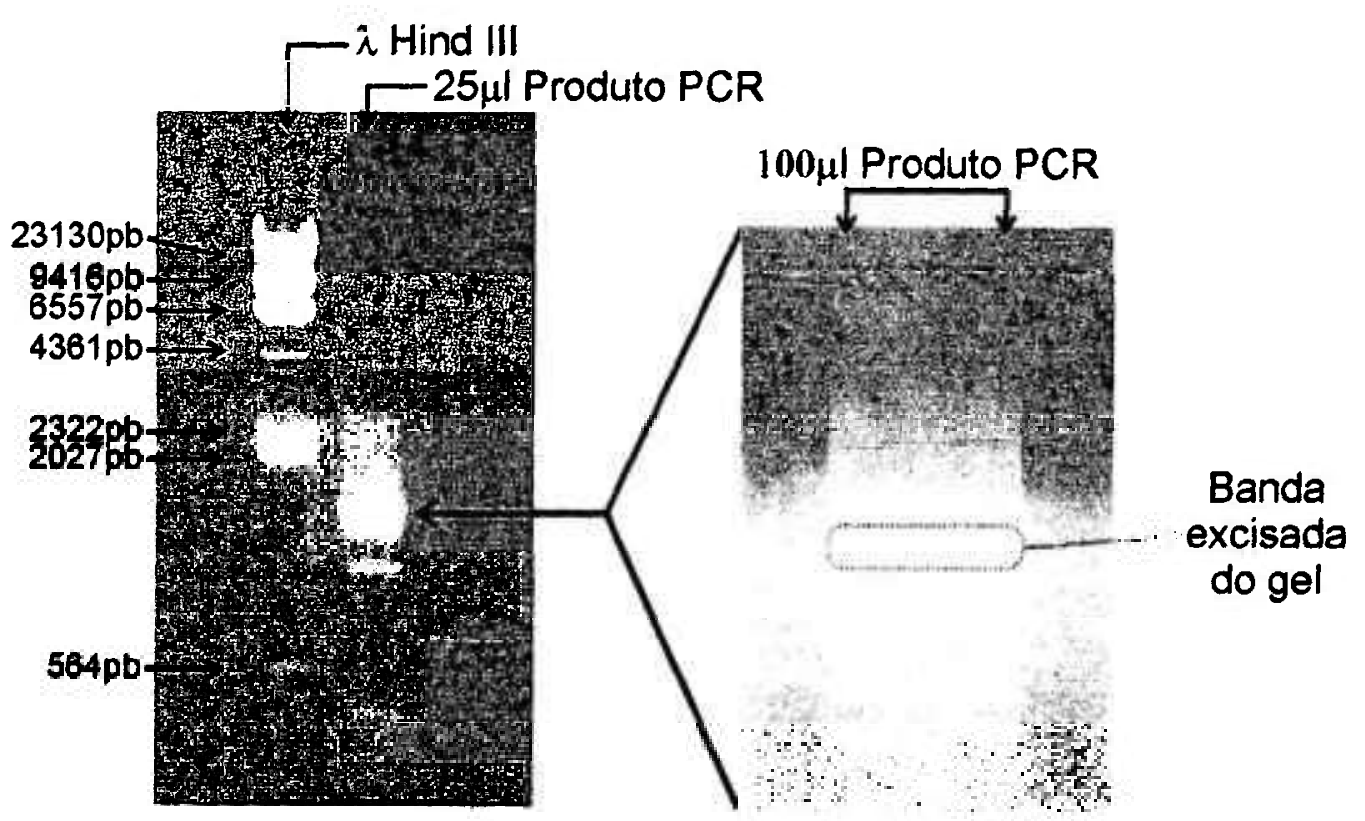

Figura 22: Obtenção dos clones pCR2.1 TOPO-PST7s. Eletroforeses em gel de agarose $1,5 \%$ do produto de amplificação da biblioteca de CDNA com os primers Peptídeo Sinal PS sense e T7. 

Scal, 293

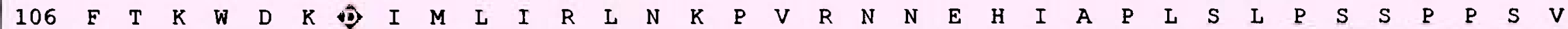

316 TTTACCAAATGGGACAAGGACATCATGTTGATCAGGCTGAACAAACCTGTTAGGAACAATGAACATATCGCGCCTCTCAGCTTGCCTTCCAGCCCTCCCAGTGTG

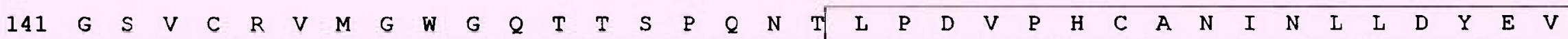
421 GGCTCAGTTTGCCGTGTTATGGGATGGGGCCAAACCACATCTCCTCAAAACA OTTTGCCCGATGTCCCTCATTGTGCTAACATTAACCTACTCGATTATGAGGTG

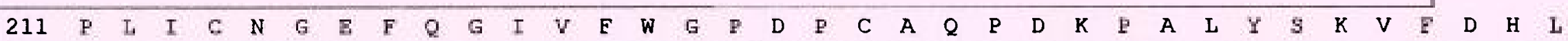
631 CCCCTCATCTGTAATGGAGAATTCCAGGGCATTGTATTTTGGGGACCTGATCCTTGTGCCCAACCGGATAAGCCTGCCCTCTACAGCAAGGTCTTCGATCATCTT ECORI, 650

$\begin{array}{llllllllllllllllllll}246 & D & W & I & Q & S & I & I & A & G & N & T & I & V & N & C & P & P & \text { Stopcódon }\end{array}$

736 GACTGGATCGAGAGCATTATTGCAGGAAATACAATTGTGAATTGCCCCCCGTGAaaactttgaaaagttaagaggagaaaatgtaacatgttagtacatctct BamHI, 741

841 tctatatccctaaccatatccaactgcattggaatatatccccaggcagtaagcttttttagactcaaataggactgcctttggagtaagaaatgctccaaata HindIII, 892

946 gtgctgcagagatcatgtcccattaatttcagtataaacaatctcagcaaatgcaggcctgttttagggtgaggtgcaaaatttctgactctaaaatggacc Pst, 954

1051 attccaaatatttaatctctgaatatcattccatttctgtccacttctgggacagtggggtccttgatgctctctgagcttctcttcttgcagacgtttcatta

1156 cccagctaggtaacatcatcagtgctacaatattctcttctattaatacttctgtggcatttacaatacgct,catatggagtcatgcggtcaccccacgaacata Ndel, 1230

1261 tccatatacccaggtcccactgttgcctaaaaggatcgcagattaagccccacttcccaatcactaaatagaatcttttaagaatcatgttttcatgtaaattc sinal de poliadenilação BamHI, 1295

1366 tcaggtatccacagcaataaaatcgtataaatcgttaaaaaaaaaaaaaaaa

gião codificante para o peptideo sinal $\square$ Região codificante para o pró-peptídeo $\backslash$ Região codificante para toxina madura $\square$ Região $3^{\prime} U T R \widetilde{\beta}$ 24: Organização do cDNA do clone PST7:4 (1420pb).

siveis éxons são: éxon 1 (1-52pb), éxon 2 (53-209pb), éxon 3 (210-473pb), éxon 4 (474-620pb), éxon 5 (621-1401pb).A região codificante para o peptídeo tá representada pela cor rosa escuro, a região codificante para o pró-peptídeo está representada pela cor rosa, a regiăo codificante para a toxina madura está entada pela cor rosa claro e a região $3^{\circ}$ UTR está representada pela cor roxa. A tríade catalítica (HDS) se encontra em diamante vermelho e o sítio potencial de silação se encontra em diamante azul. O sinal de início (ATG) e o códon de parada (Stop códon-TGA) se encontram em negrito. O sítio destacado em amarelo na $1381 \mathrm{pb}$ representa o sinal de poliadenilação. 


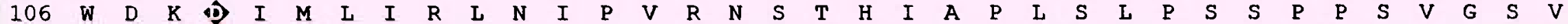
316 TGGGACAAGGACATCATGTTGATCAGGCTGAACATACCTGTTAGGAACAGTACACACATCGCGCCTCTCAGCTTGCCTTCCAGCCCTCCCAGTGTGGGCTCAGTT

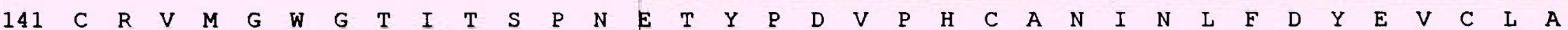
421 TGCCGTGTTATGGGATGGGGCACAATCACATCTCCTAATGAGACTTATCCCGATGTTCCTCATTGTGCTAACATTAACCTATTCGATTATGAGGTGTGTCTAGCA

$\begin{array}{lllllllllllllllll}246 & Q & S & I & I & A & G & N & T & A & V & T & C & P & P & \text { Stop códon }\end{array}$

736 CAGAGCATTATTGCAGGAAATACAGCTGTGACTTGCCCCCCATGAaactttgaaaagttaagaggagaaaatgtaacatattagtacatctcttctatatct

841 ctaaccatatccaattacattggaatatattcccagacagtaagcttttttacactcaaacaggacttccttggagtaagaaatgctcaagatagtgctgcao HindIII, 883

946 ggatcatgtcccatttaattcagtataaacaatctcagtaaatggaggcctgttttagggtgaggtgcaaaatttctgactctaaaatggaccattccaaa

1051 tatttaacctctgaatatcttccattctgtccacttctgggacagtggggtcttgatgctctctgagcttgtcttcttgcagacgtttcattacccagcta 1156 ggtaacatcatcagtgctagaatattctcttctattggtacttgtgtggcatttacaatacgctcatgtggagtcatgcagtcacccataaacatatccatatac 1261 ccgggtcccattgttgcctaaaaggatcccagattaagcctcacttcccaatcactaaatagaatctttgagaatcatgttttcatgtaaattctcaggtatc Sma I, 1263 sinal de poliadenilação

1366 cacagaataaattgtataatcoaaaaaaaaaaaaaa

jião codificante para o peptídeo sinal $\square$ Região codificante para o pró-peptídeo $\square$ Região codificante para toxina madura

25: Organizaçăo do cDNA do clone PST7: 7e8 (1407pb).

siveis éxons são:éxon 1 (1-52pb), éxon 2 (53-200pb), éxon 3 (201-460pb), éxon 4 (461-6110pb), éxon 5 (612-1389pb).A região codificante para o peptídeo tá representada pela cor rosa escuro, a regiăo codificante para o pró-peptídeo está representada pela cor rosa, a região codificante para a toxina madura está entada pela cor rosa daro e a região $3^{\prime}$ UTR está representada pela cor roxa. O sítio destacado em amarelo na posição $1372 \mathrm{pb}$ representa o sinal de nilação. O códon de início (ATG) e o códon de parada (Stop códon-TGA) se encontram em negrito.A tríade catalítica (HDS) se encontra em diamante vermelho e sotenciais de $\mathrm{N}$-glicosilação se encontram em diamantes azuis. 


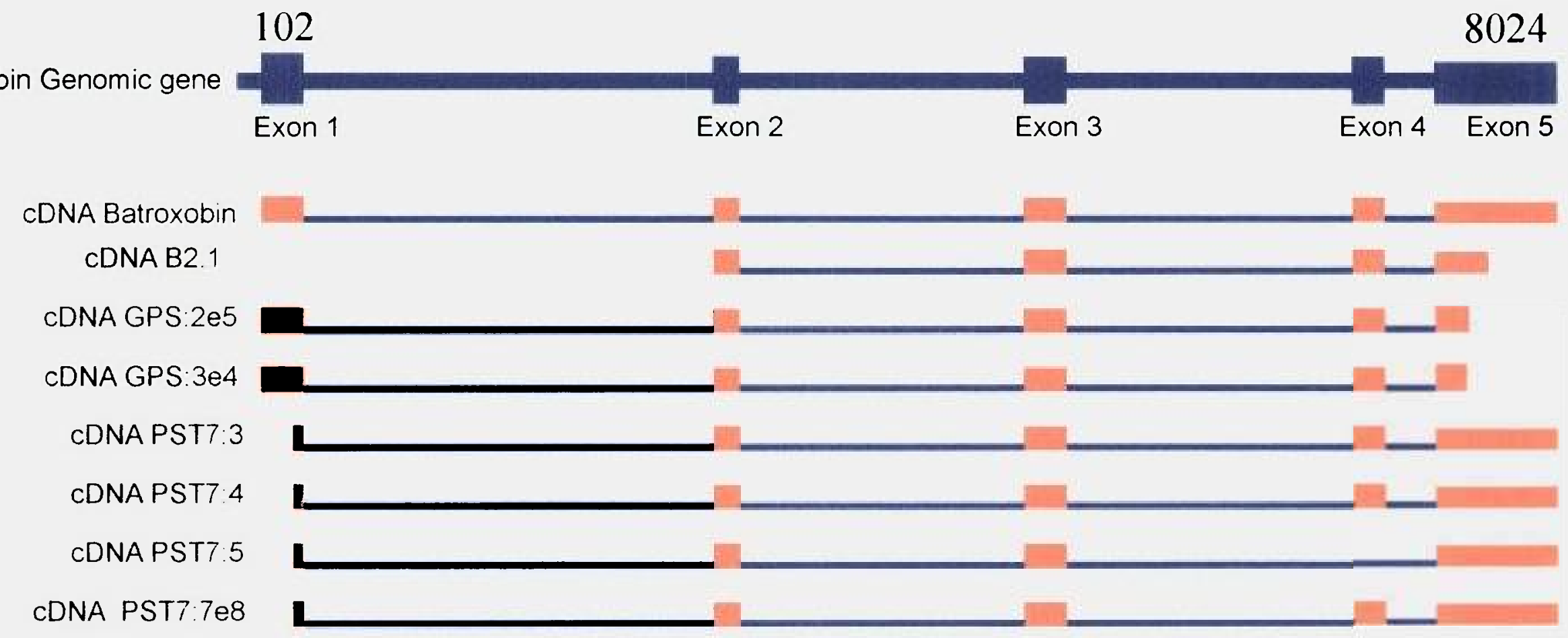

Figura 27: Análise da organização dos cDNAs.

As seqüências de 7 clones Giroxina símile em relação à organização genômica do gene de Batroxobin de Bothrops atrox (X12747) e o cDNA de Batroxobin (J02684). 


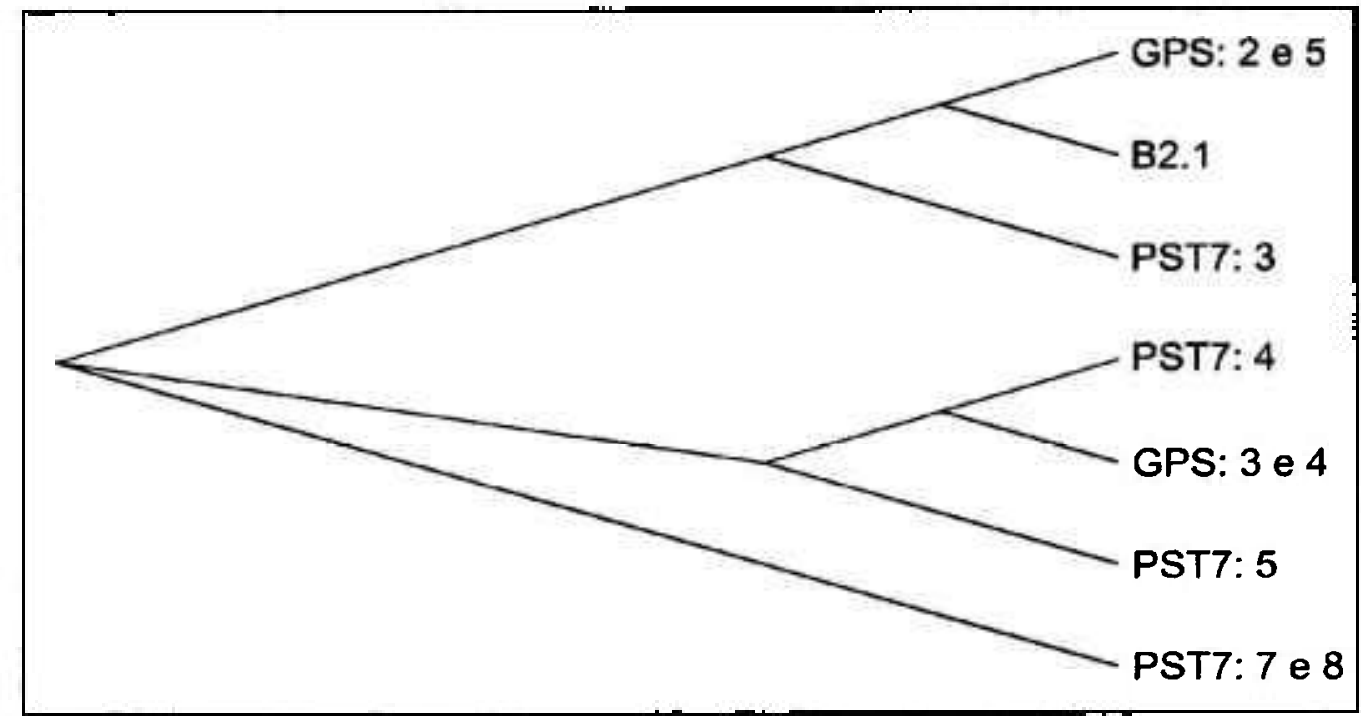

Figura 28: Dendrograma das seqüências de nucleotídeos dos clones de cDNA B2.1, GPS:2e5, GPS:3e4, PST7:3, PST7:4, PST7:5 e PST7:7e8. 

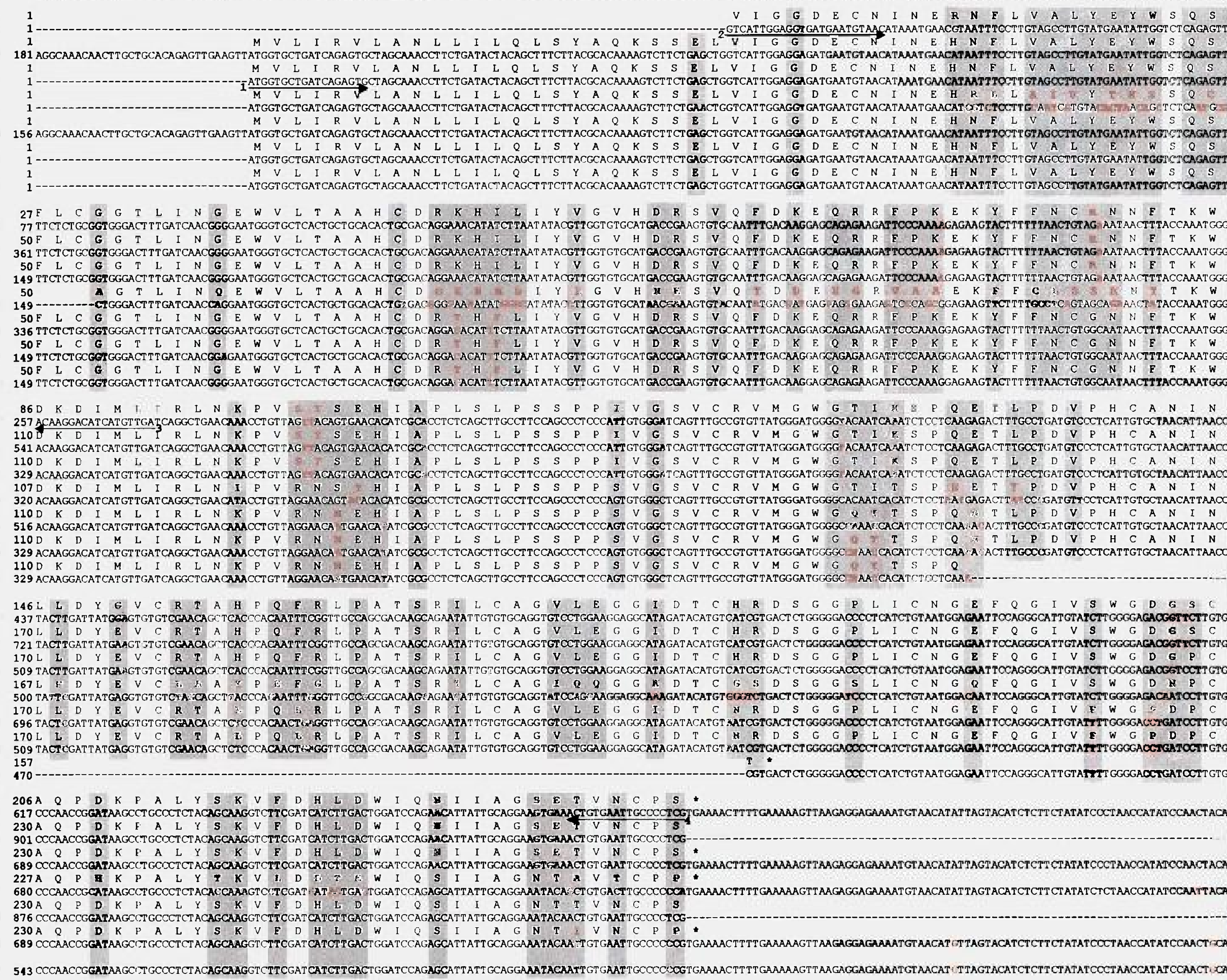

Sito de poliadenilação

797 TTGGAATATATCCOCAGGCAGTAAGCTTTTTTTTAGACTCAAAT AGGACTGCCTTTGGAGTAATAAATT:LCTCAAAATAGT GCTGC-

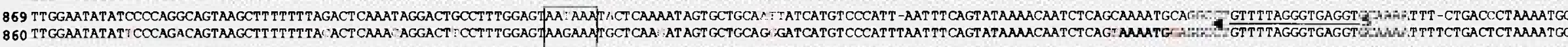

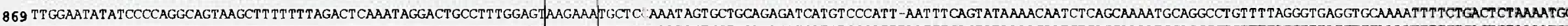

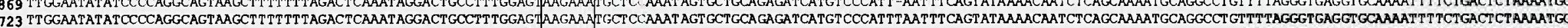
881

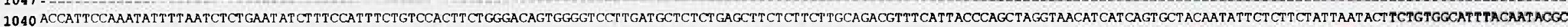

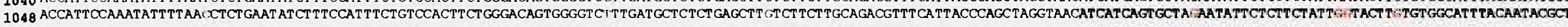

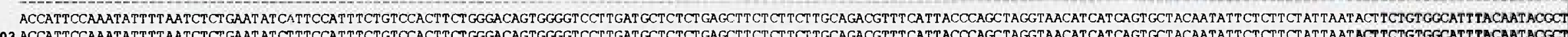
903 881

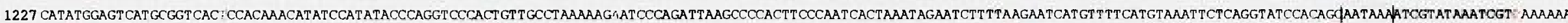

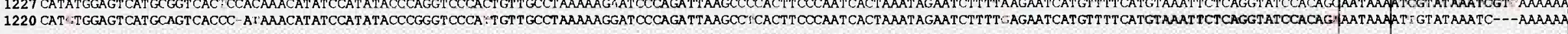

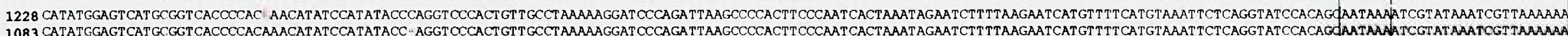
1083 CATATGGAGTCATGCGGTCACCCCACAAACA

1408 AAAAAAAAAAAAA-

1262 AAAAAAAAAAA--

\section{ura 29: Alinhamento em nucleotídeos e aminoácidos dos clones B2.1, GPS: 2e5, PST7:3, PST7:7e8, GPS: 3e 4, PST7:4 e PST7:5.}

Ione PST7:7e8 está destacado na cor cinza claro separando os outros clones em dois grupos. As letras vermelhas indicam as mutações nucleotídeos ou de aminoácidos e as colunas cinza escuro indicam as regiões afetadas nas toxinas. A caixa vazia indica os sítios enciais de poliadenilação. As caixas cinza claro indicam os sítios de poliadenilação (AATAAA). As regiōes de hibridação dos primers ão representadas pelas setas $\left(5^{\circ} \rightarrow 3^{\prime}\right.$-sense) e ( $3^{\prime} \leftarrow 5^{\prime}$ - antisense). A numeração indica quais são os primers: 1- Peptideo Sinal, 2- GYR 3- GYRAS 2, 4-GYRAS 1, 5-PST7AS. 


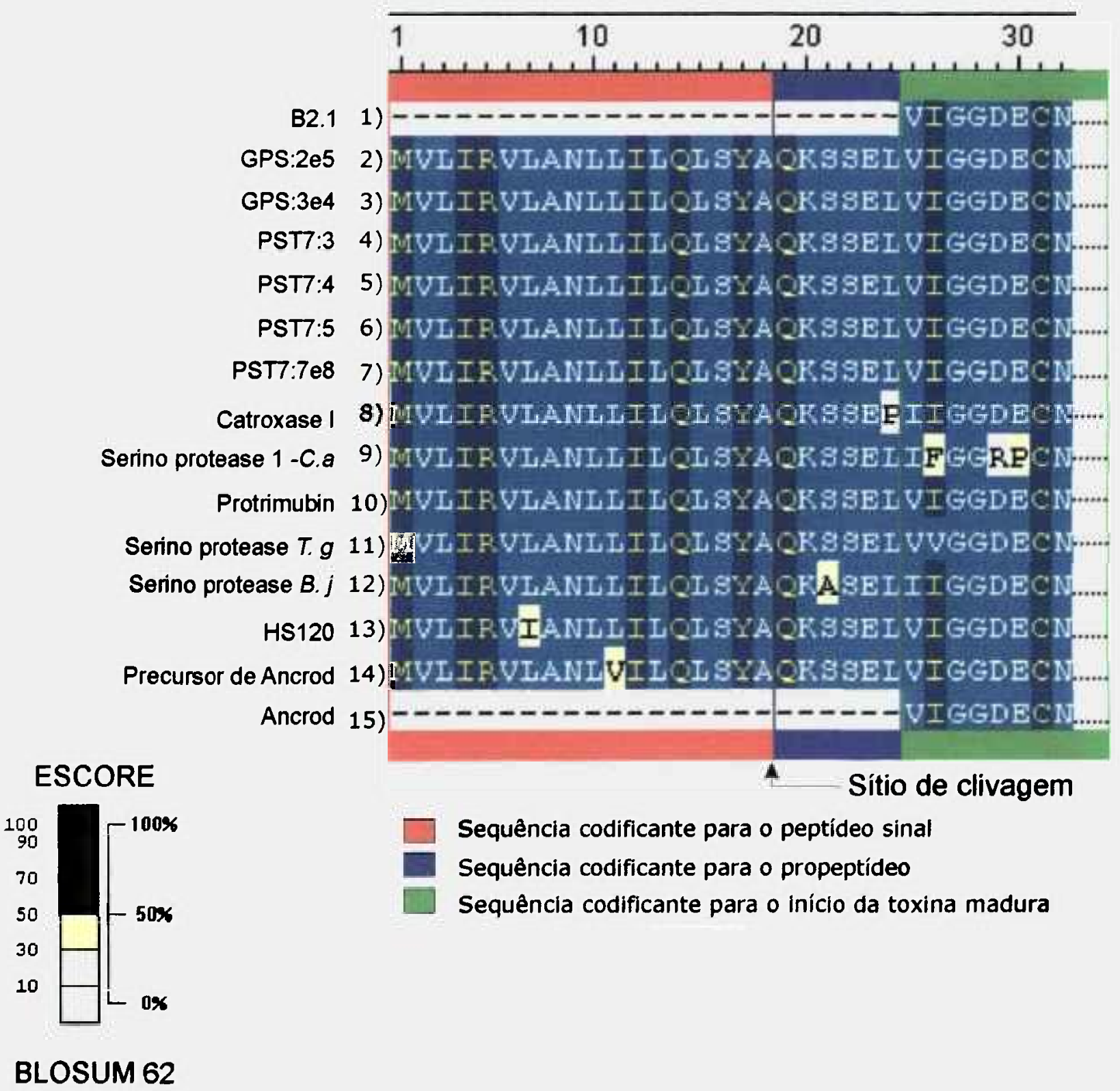

Figura 30: Análise do precursor.

1) B2.1 de Crotalus durissus terrificus (AY954040); 2) GPS:2e5 de Crotalus durissus terrificus; 3) GPS:3e4 de Crotalus durissus terrificus; 4) PST7:3 de Crotalus durissus terrificus; 5) PST7:4 de Crotalus durissus terrificus; 6) PST7:5 de Crotalus durissus terrificus; 7) PST7:7e8 de Crotalus durissus terrificus; 8) Catroxase I de Crotalus atrox (AF227153.1);9) Serino protease 1 de Crotalus adamanteus (AJ251525.1);10) Protrimubin de Trimeresurus mucrosquamatus (U31417);11) Serino protease de Trimeresurus gramineu (D67083.1); 12) Serino protease de Bothrops jararacussu (AY251282.1); 13) HS 120 de Bothrops jararaca (AB178323.1); 14) Precursor de Ancrod de Agkistrodon rhodostoma (P47797); 15) Ancrod de Agkistrodon rhodostoma (P26324). A seta indica o sitio de clivagem do peptídeo sinal. 
SignalP-HMM prediction (ouk models), PST? 3

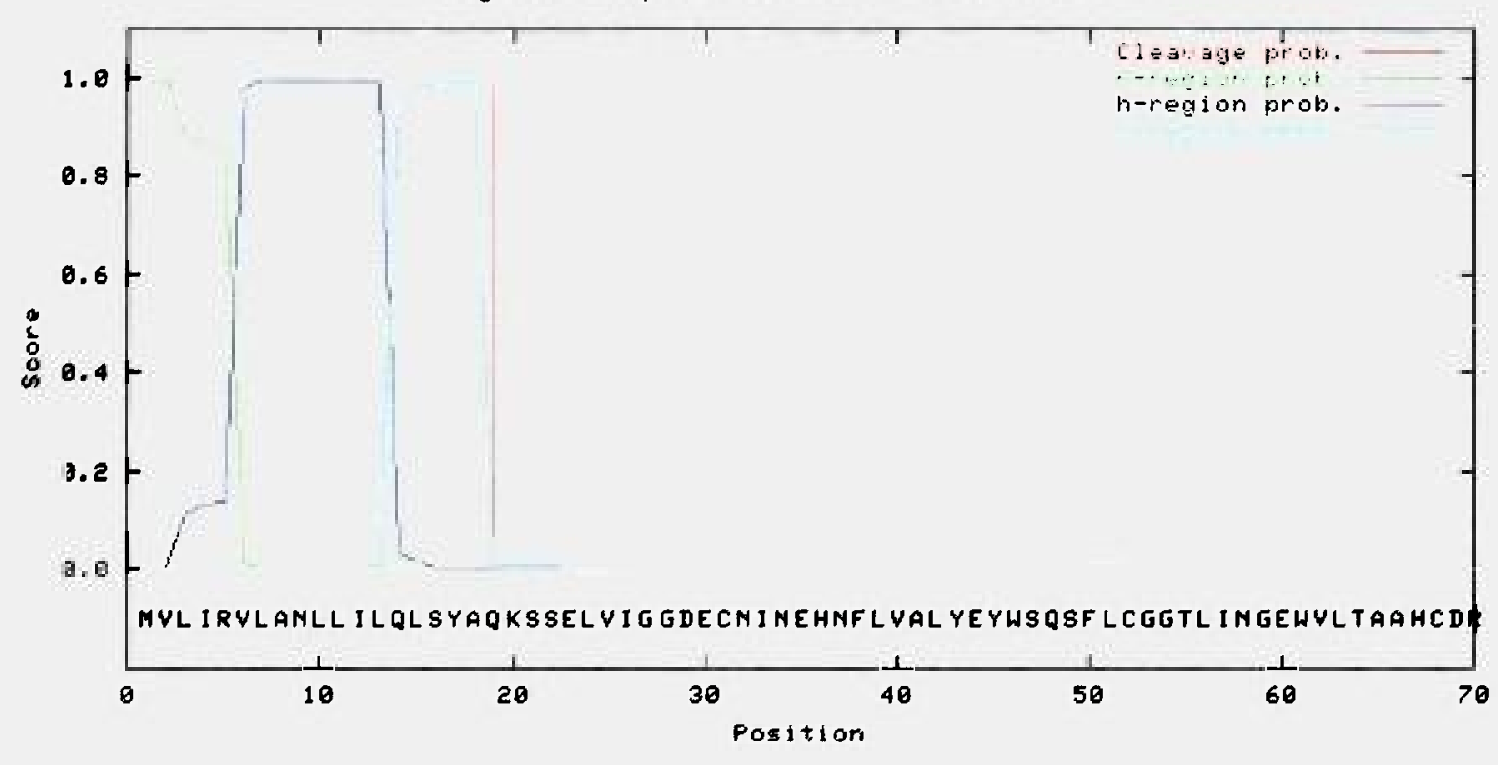

Figura 31: Predição de clivagem do peptídeo sinal do clone PST7:3.

O peptídeo sinal é clivado na posição 18 entre os aminoácidos $A-Q$, liberando uma toxina inativa com um pró-peptídeo de 6 aminoácidos. 


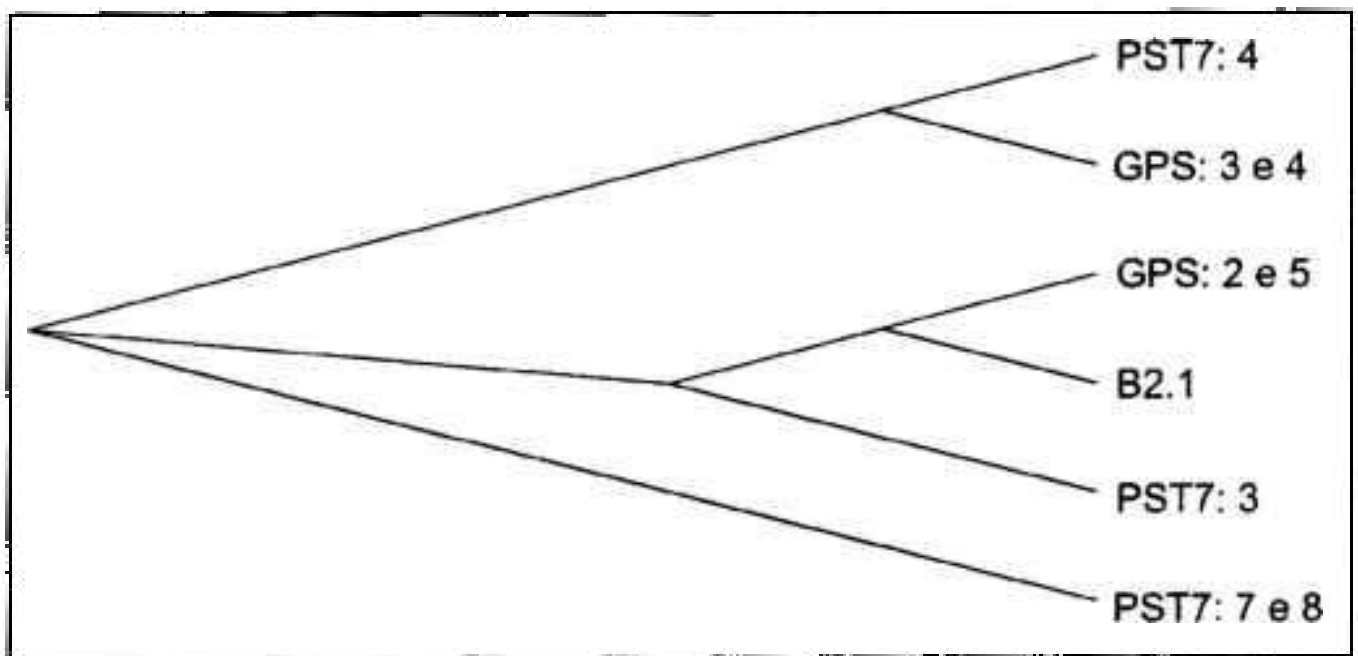

Figura 32: Dendrograma das sequêencias de aminoácidos correspondentes às toxinas maduras codificadas pelos clones: B2.1, GPS:2e5, GPS:3e4, PST7:3, PST7:4 e PST7:7e8. 


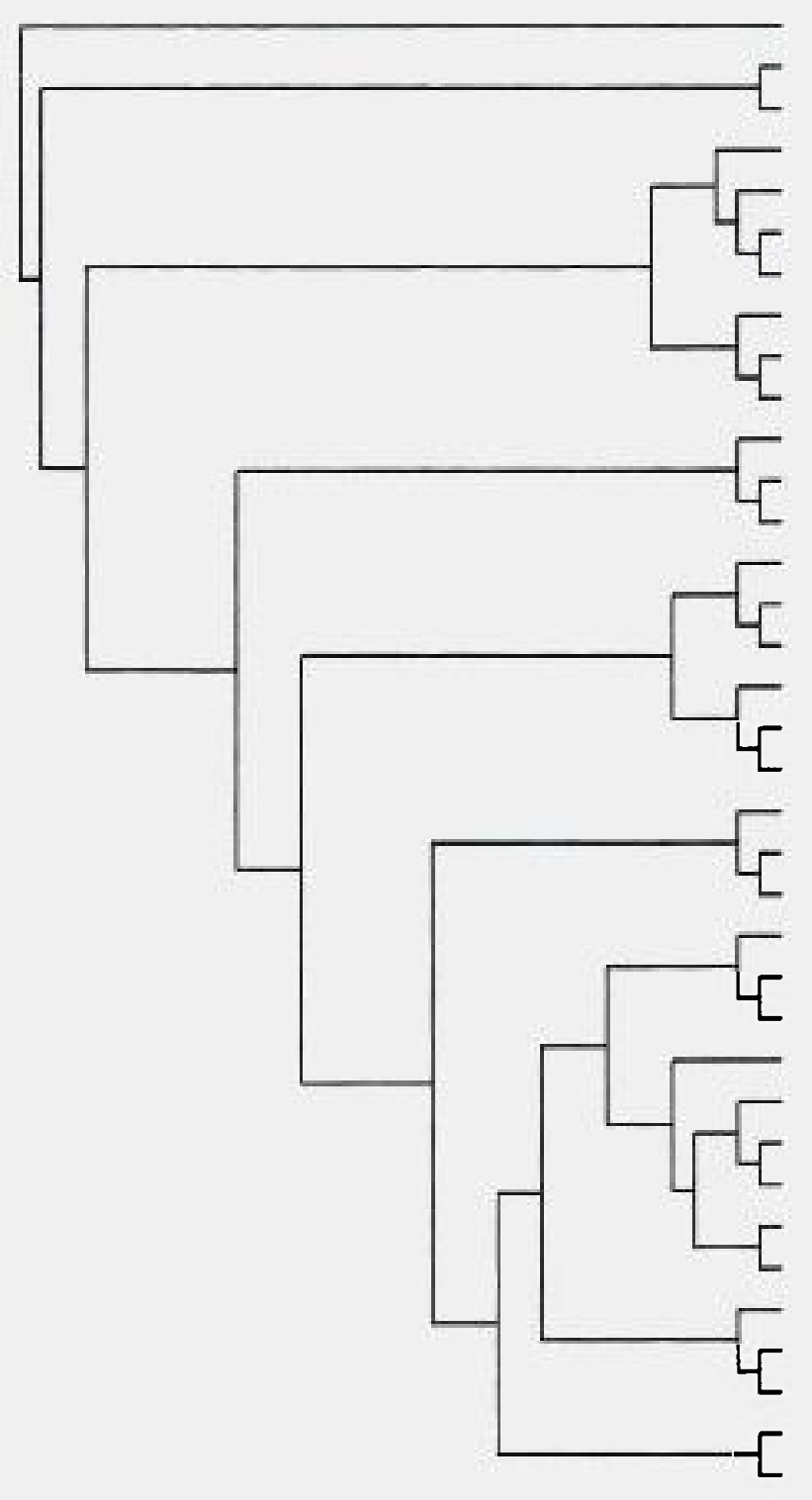

Trypsin (Sus scrofa)

FVA (lipera lebetina)

111

$\mathrm{RW}-\mathrm{V} \propto$ (Daboia russelli siamensis)

Catroxase II (Crotalus atrox)

Dav-PA (Agkistrodon acutus)

Flavoxobin (Trimeresurus flavoviridis )

Contortrixobin (Agkistrodon contortrix contortrix)

PA-BJ (Bothrops jararaca)

LV-PA (Lachesis muta muta)

TSV-PA(Trimeresurus stejnegeri)

Calobin (Agkistrodon caliginosus)

Pallabin-2 (Agkistrodon halys pallas)

Halystase (Agkistrodon halys blomhoffii)

KN-BJ (Bothrops jararaca)

Sp1 (Crotalus adamanteus)

Catroxase I (Crotalus atrox)

Elegaxobin (Trimeresurus elegans)

Mucrofibrase-1 (Trimeresurus mucrosquamatus)

DAV-KN (Agkistrodon acutus)

ACC-C (Agkistrodon contortrix contortrix)

PST7: 7 e 8 (Crotalus durissus terificus)

CPI Enzyme - 2 (Agkistrodon caliginosus)

Bilineobin (Agkistrodon bilineatus)

Gyroxin analog (Lachesis muta muta)

Ancrod (Agkistrodon rhodostoma)

Crotalase (Crotalus adamanteus)

PST7: 3 (Crotalus durissus terrificus)

GPS: 2 e 5 (Crotalus durissus terrificus)

Gyroxin-like B2.1 (Crotalus durissus terrificus)

PST7: 4(Crotalus durissus terificus)

GPS: 3 e 4 (Crotalus durissus terrificus)

DAV-X (Agkistrodon acutus)

Acutobin (Agkistrodon acutus)

TLG2B (Trimeresurus gramineus)

Bothrombin (Bothrops jararaca)

Batroxobin (Bothrops atrox)

Figura 33: Dendrograma funcional de serino proteases do veneno de serpentes.

I-Ativador de Fator V. II -Ativador de Plasminogênio. III -Fibrinogenases. IIla- $\alpha$ flibrinogenases.

IIIb-c e/ou $\beta$ fibrinogenases. N- enzimas trombina-símile. IVa-enzimas que atuam sobre a coagulaçăo.

IVb-enzimas que pertencem ao grupo da toxina ativadora de proteína C (ACC-C) de Agkistrodon contortrix contortrix.

Atripsina foi usada como grupo externo.

Trypsin Tripsina de suino, Sus scrofa (P00761- Huang et al 1993); FVA Factor V-activating enzyme, Vipera lebetina (Q9PT41Siigur et al, 1999); RVV-Va Vipera russelli proteinase, Daboia russelli siamensis (P18964 - Tokunaga et al 1988): Catroxase-2, Crotalus atrox (Q8QHK2- Bjarnason et al, 1983); Dav-PA, Agkistrodon acutus (Q918X1- Wang et al, 2001); Flavoxobin, Trimeresurus flavoviridis (P05620-Deshimaru et al, 1996); Contortrixobin, Agkistrodon contortrix contortrix (P82981-Amiconi et al, 2000); PA-BJ, Bothrops jarareca (P81824-Serrano et al, 1995); LV-PA, Lachesis muta muta (P84036-Sanchez et al, 2000);TSV-PA, Trimeresurus steinegeri (Q91516 - Zhang ot al, 1995); Calobin, Agkistrodon caliginosus (Q91053 - Hahn et al 1996); Pallabin-2, Agkistrodon halys pallas (Q9Y GI6-Fan et al, 1999); Halystase, Agkistrodon halys blomhoffii (P81176- Matsui et al. 1998); KNBJ, Bothrops jararaca (013069- Serrano et al, 1998); Venom serine proteinase Sp1, Crotalus adamanteus (Q8UUK2); Catroxase-1, Crotalus atrox (Q8QHK3); Elegaxobin-1, Trimeresurus elegans (P84788- Oyama et al, 2002) Mucrofibrase-1. Trimeresurus mucrosquamatus (Q91507-Hung et al, 1994). Dav-KN, Agkistrodon acutus (Q918X0-Wang et al, 2001); ACC-C Protein C activator; Agkistrodon contortrix contortrix (P09872- McMullen et al, 1989); PST7: 7e8 de Crotalus durissus temificus; CPI enzyme-2, Agkistrodon caliginosus (042207- Hahn et al, 1998); Bilineobin, Agkistrodon bilineatus (Q9PSN3- Nikai et al, 1995); Gyroxin analog, Lachesis muta muta (P33589 - Magalhăes et al,1993); Ancrod,Agkistrodon thodostoma (P26324 - Burkhart et al, 1992); Crotalase, Crotalus adamanteus (Henschen-Edman et al, 1999); PST7: 3 de Crotalus durissus terrificus; Gyroxin-like B2.1, Crotalus durissus terificus (Q58G94); GPS: 205 de Crotalus durissus terrificus; PST7: 4 de Crotalus durissus temificus; GPS: 3 e4 de Crotalus durissus terrificus; Dav-X, Agkistrodon acutus (Q918W9-Wang et al, 2001); Acutobin, Agkistrodon acutus (Q918X2- Wang et al, 2001);TLG-2B, Trimeresurus gramineus (O13061- Deshimaru et al, 1996); Bothrombin, Bothrops jararaca (P81681-Nishida et al, 1994); Batroxobin, Bothrops atrox (P04971- Itoh et al, 1987). 


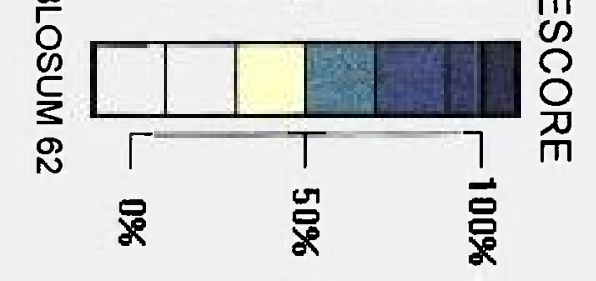

윽ํำ

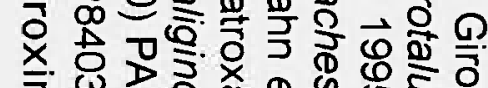

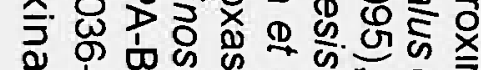
ஸे

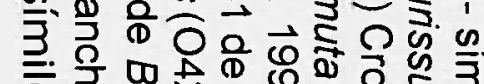
ब市吹 罚

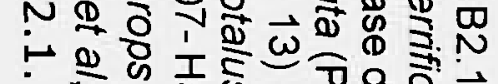

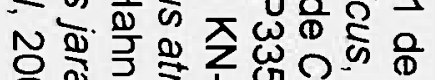
요워

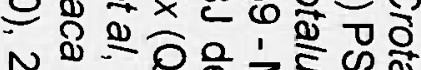
N س

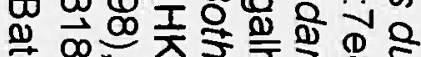
范 的舟

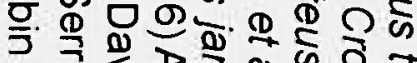

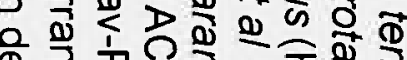

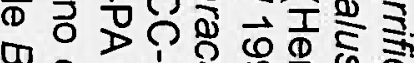

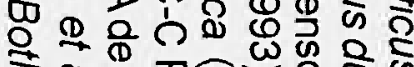

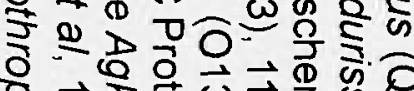

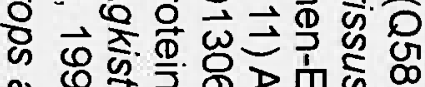
ڤ

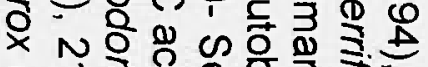

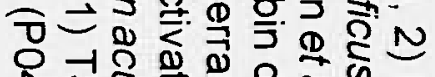

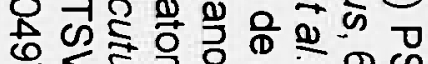

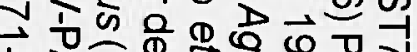

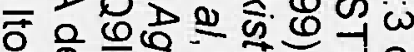
(1) Q

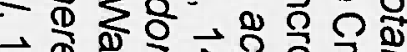
$\overrightarrow{0}$ Фั 닝ㅇำ $\supset$ के ว

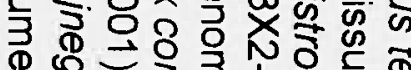
蛋 蚁 。

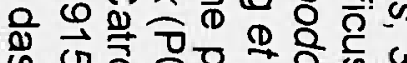
○ $\vec{\sigma} \times$

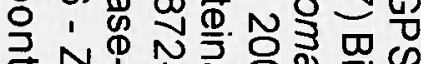

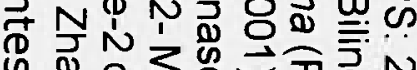

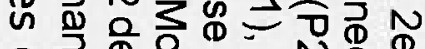

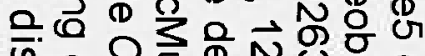

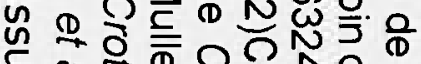

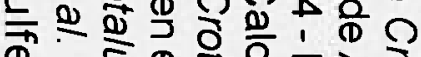
D $\rightarrow \stackrel{\mathbb{9}}{\rightarrow}$ 음

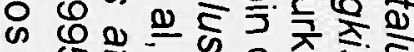

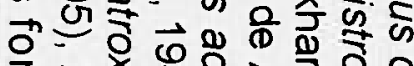

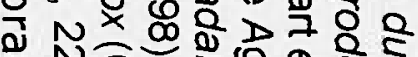
3 N.

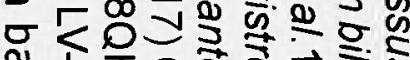

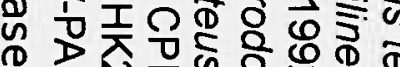
政 은 उ व 饮

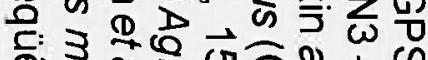

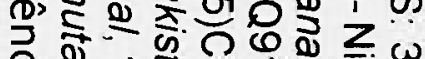
ㄱ.

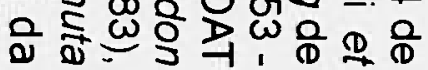

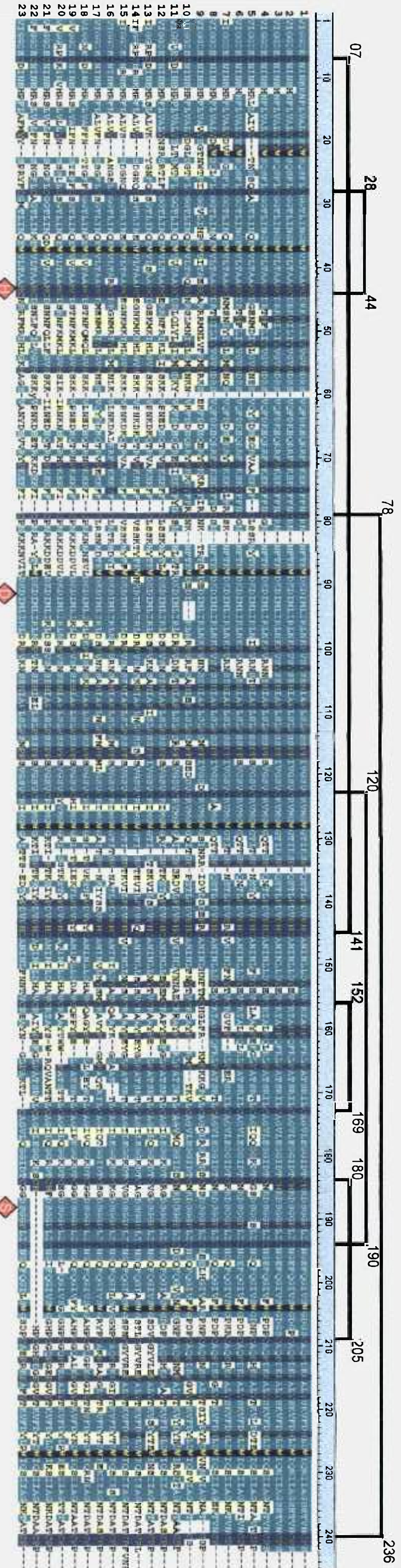



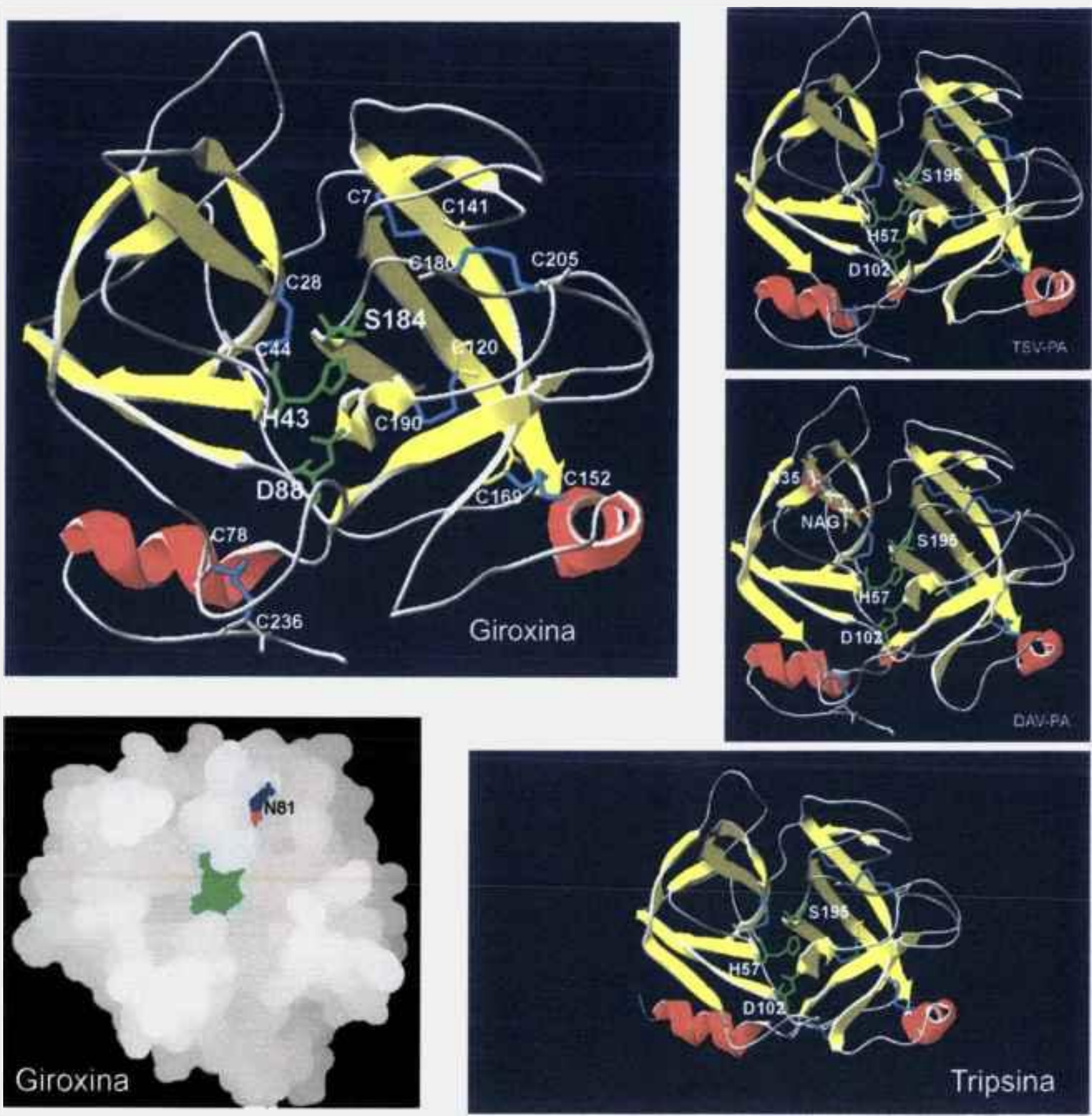

Figura 35: Modelo tridimensional da giroxina.

A estrutura terciária da giroxina pode ser comparada com a estrutura terciária do modelo cristalográfico da TSV-PA (1bqy), da DAV-PA (1op2) e da tripsina (2ptc). Em amarelo são mostradas as folhas $\beta$-pregueadas que compozem os dois domínios em barril- $\beta$. Em vermelho as $\alpha$-hélices, em azul as pontes dissulfeto e em verde os aminoácidos da tríade catalítica. No modelo de superfície da giroxina é possível visualizar em azul a cadeia lateral da asparagina 81 estando mostrado em vermelho o nitrogênio do sítio potencial de $\mathrm{N}$-glicosilação. Em verde está mostrado a posição dos aminoácidos que participam da tríade catalítica. No modelo da DAV-PA é mostrado o sítio de glicosilação da asparagina 35 com o monosacarídeo NAG. 

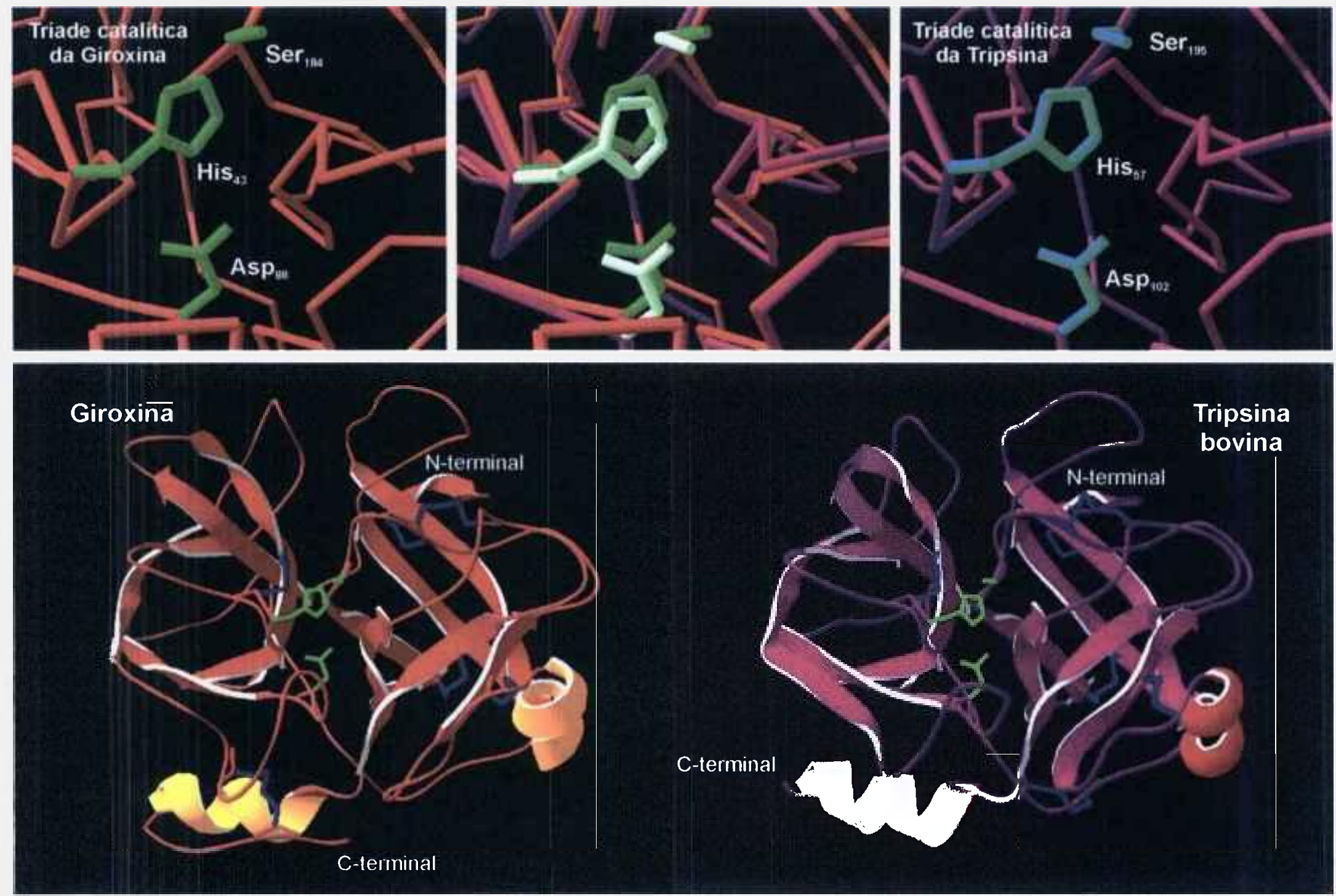

Figura 36: Comparação do modelo da giroxina com o modelo cristalográfico da tripsina bovina (2ptc).

O modelo da giroxina foi baseado no modelo cristalográfico de Trimeresurus stejnejeri TSV-PA (1bqy), de Agkistrodon acutus AaV-SP I (10p0), de Agkistrodon acutus AaV-SP II- DAV-PA (10p2). Nos modelos da giroxina e da tripsina, as folhas $\beta$-pregueadas que compõem os dois domínios em barril- $\beta$ estão mostrados em vermelho e em rosa respectivamente, as $\alpha$-hélices em laranja e vermelho respectivamente, as pontes dissulfeto estão em azul e em verde os aminoácidos da triade catalítica. 

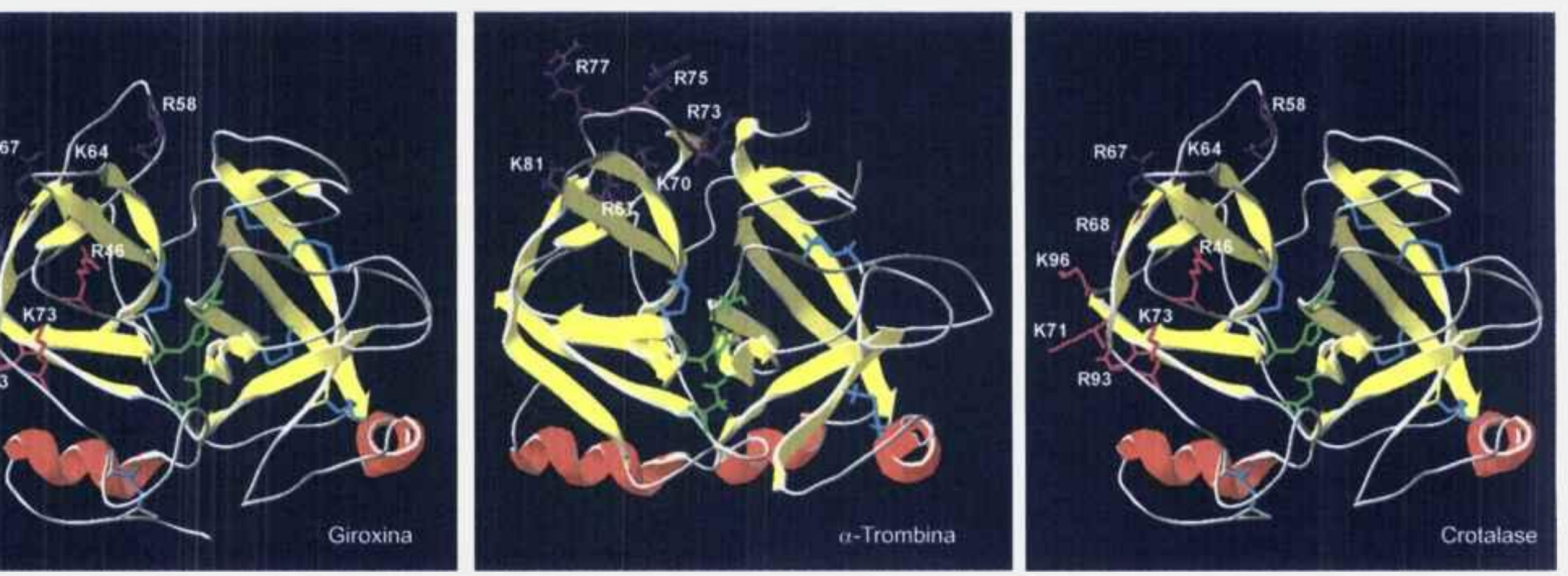

ra37: Comparação dos modelos tridimensionais da giroxina e crotalase com o modelo cristalográfico da cadeia pesada da $\alpha$ - trombina ana $(1 \mathrm{c} 50)$.

amarelo são mostradas as folhas $\beta$-pregueadas que compöem os dois domínios em barril- $\beta$, em vermelho as $\alpha$-hélices, em azul as pontes Ifetos e em verde os aminoácidos da triade catalítica. Em rosa está representado as cadeias laterais dos aminoácidos que compõem um alternativo de ligação ao fibrinogênio e em roxo as cadeias laterais dos aminoácidos que compõem o sítio de ligação ao fibrinogênio. 

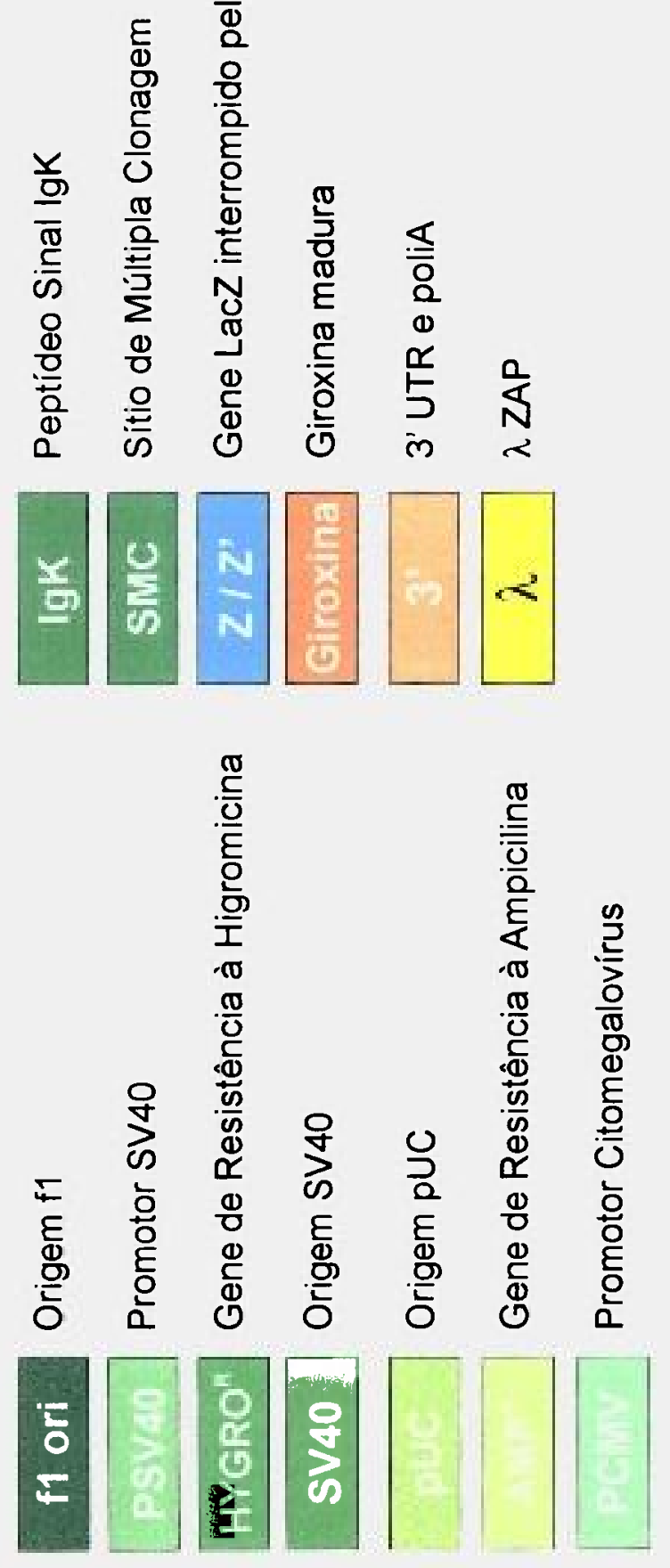


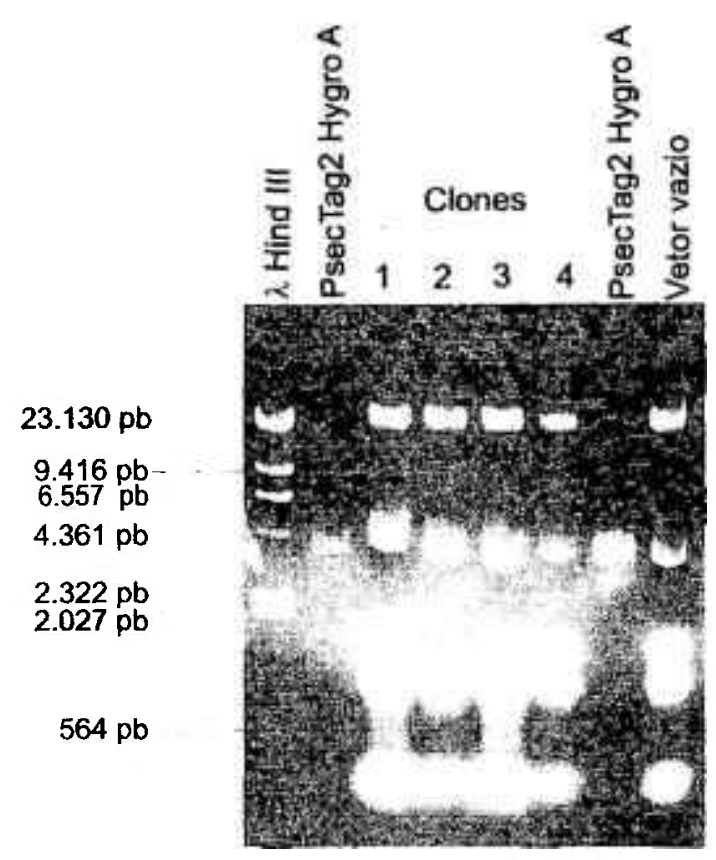

Figura 40: Seleção do clone pSecTag2-Giro.

Análise em gel de agarose $1,5 \%$ relativo à seleção dos clones recombinantes por tamanho.

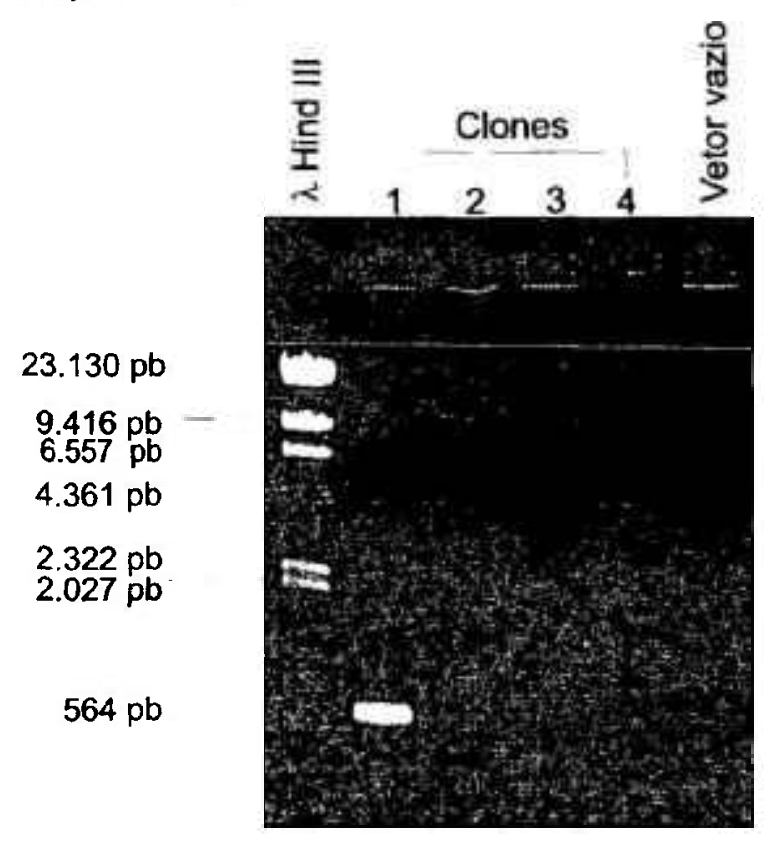

Figura 41: Análise por PCR do clone pSecTag2-Giro recombinante.

Eletroforese em gel de agarose 1,5\%. O plasmídeo pSecTag2 vazio (controle negativo) e os clones de 1 a 4 foram amplificados por PCR com os primers GYR SE e GYR AS1. 


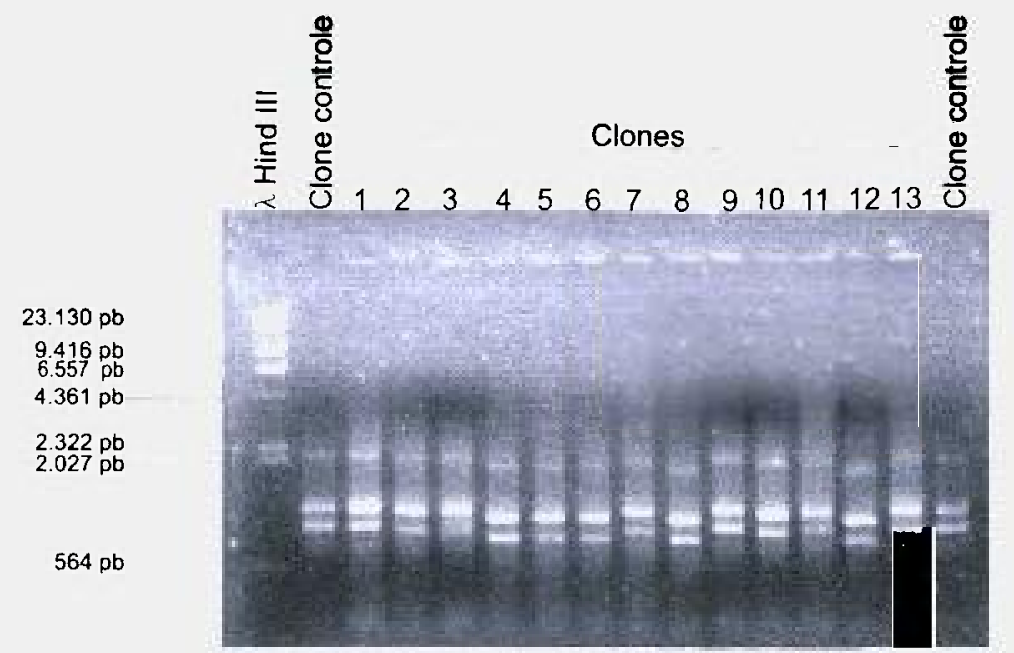

Figura 42: Seleção por PCR dos clones pSecTag2-IgK-Giro obtidos após a mutagênese sítio dirigida.

Análise de gel de agarose 1,5\% referente à seleção dos clones recombinantes por PCR utilizando-se os primers sense T7 e GYR AS1. A dupla banda amplificada é devido a dois sítios do primer $T 7$ presente na construção pSecTag2-IgK-Giro. Os clones controles correspondem ao vetor parental pSecTag2-Giro não mutado.

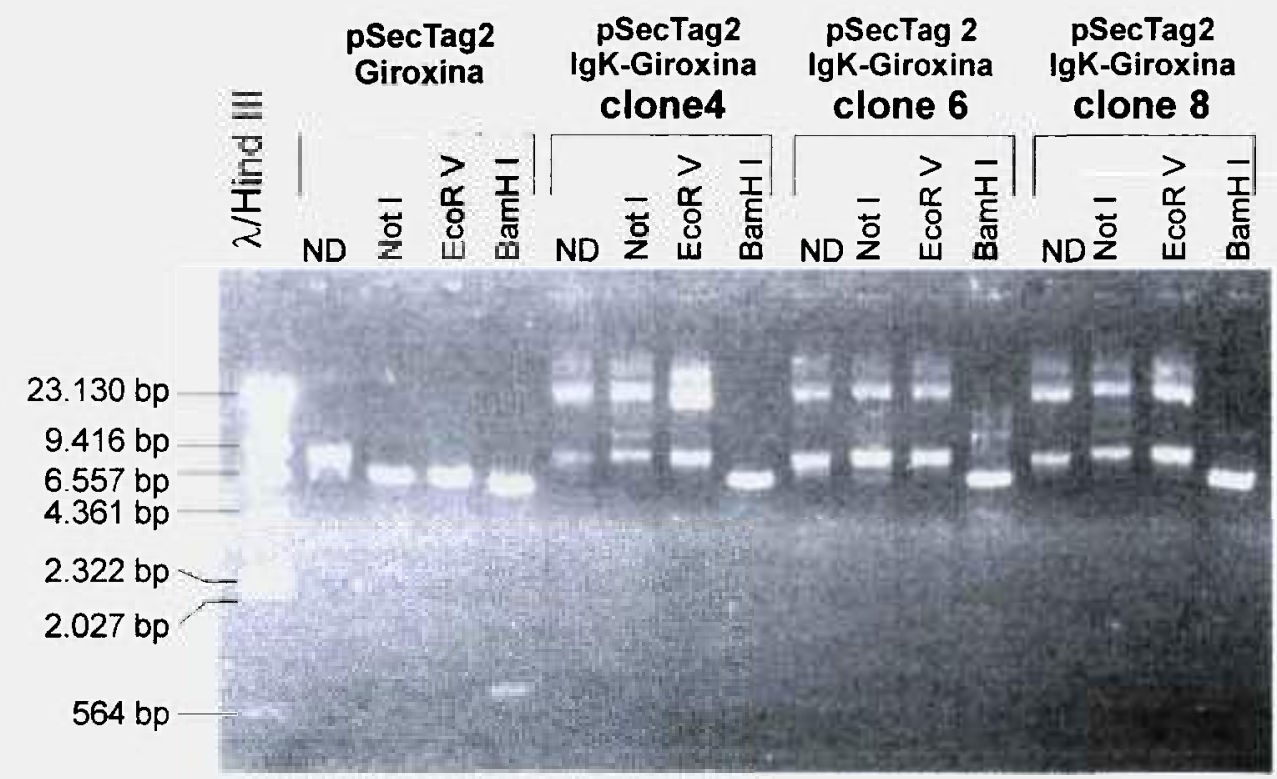

Figura 43: Análise de restrição dos clones mutantes pSecTag2-IgK-Giro.

Análise em gel de agarose $1,5 \%$ do produto da digestão dos clones recombinantes. Como controle negativo foi utilizado o vetor parental pSecTag2-Giro não mutado. 


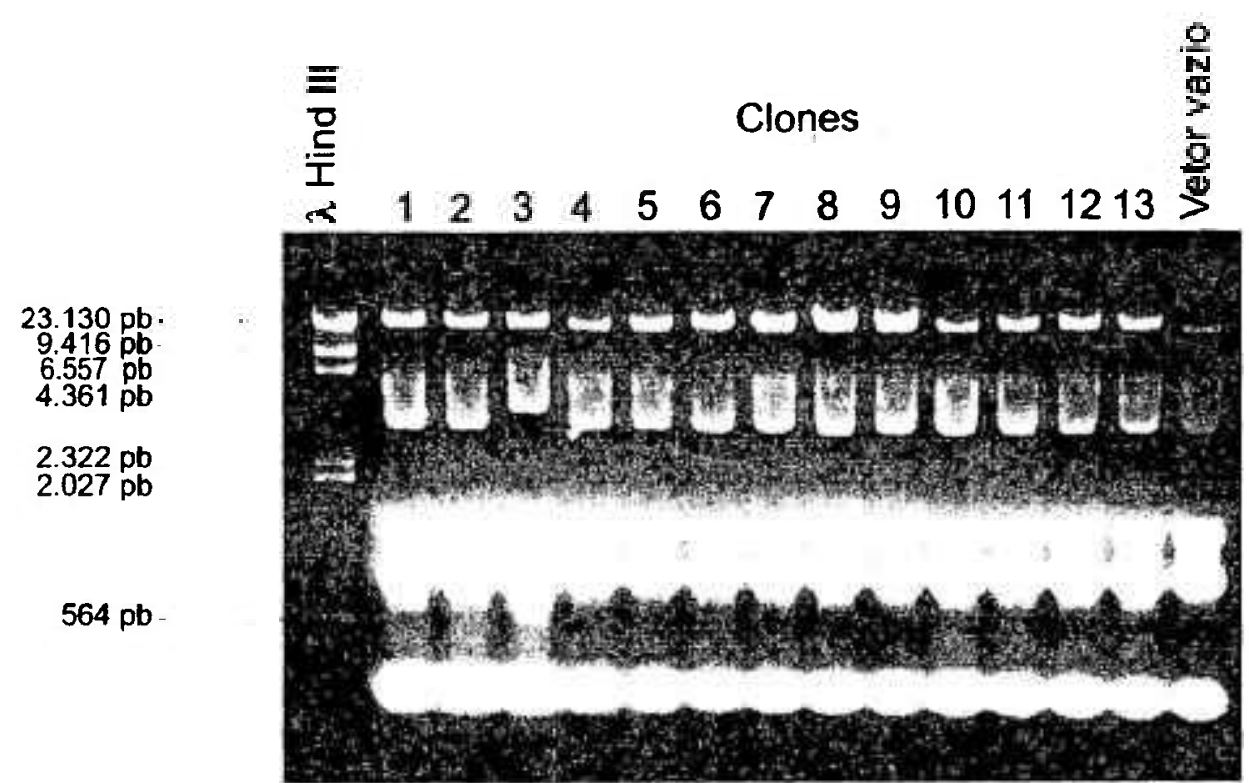

Figura 45: Seleção por tamanho dos clones recombinantes pED-Giro.

Eletroforese em gel de agarose $1,5 \%$ da extração do DNA plasmidial dos clones de 1 a 13. Como controle foi utilizado uma colônia transformada com o vetor PED vazio.

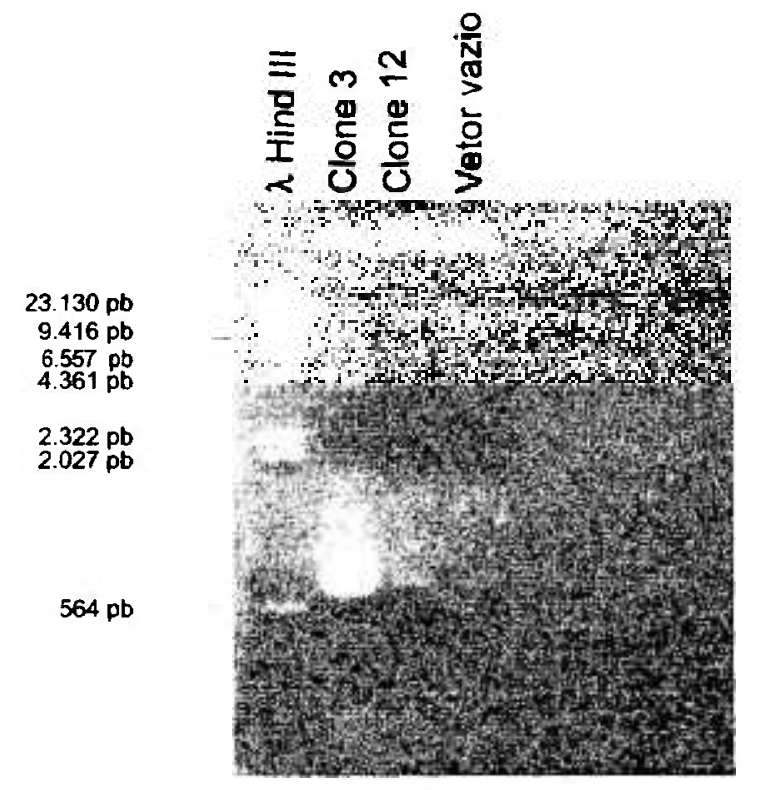

Figura 46: Análise por PCR do clone pED-Giro recombinante.

Eletroforese em gel de agarose 1,5\%. O plasmídeo pED vazio (controle negativo) e os clones de 3 e 12 foram amplificados por PCR com os primers GYR SE e GYR AS1. 


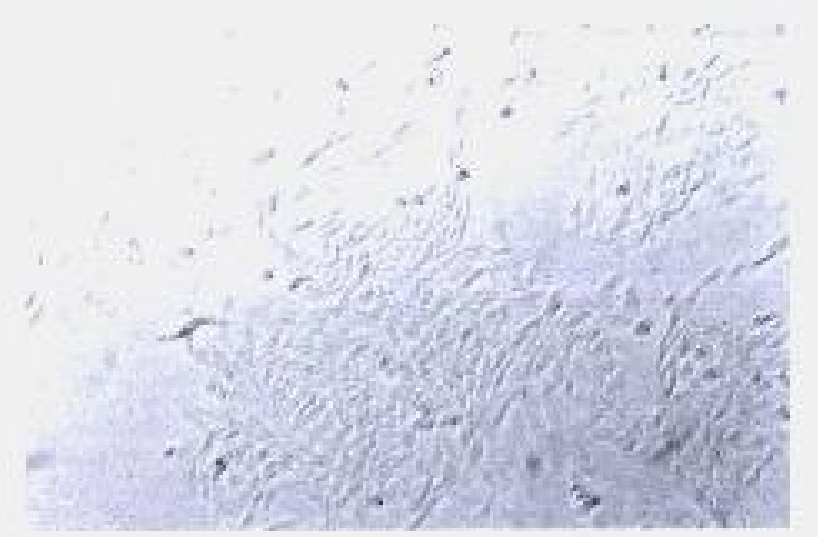

Figura 48: Uma colônia de células CHO-DXB11 transfectada com o vetor pED-Giro.

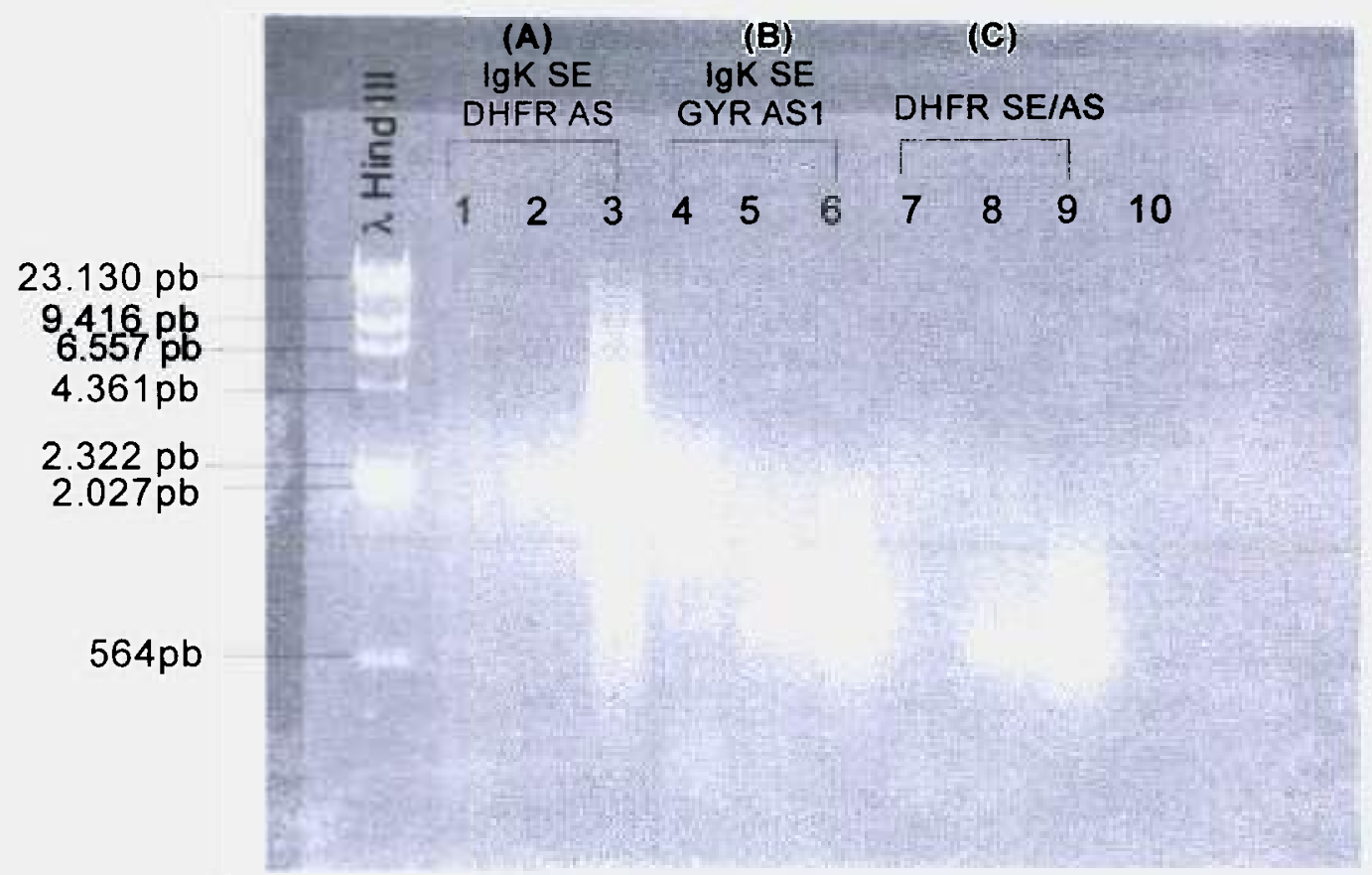

Figura 49: Deteç̧ão do vetor pED-Giro integrado no genoma da célula CHO DXB11.

PCR do extrato total das amostras: CHO DXB11 dhfr (1, 4 e 7), clone 6 (2, 5 e 8), plasmídeo pED-Giro (3, 6 e 9), 10- água com os primers IgK SE/ GYR AS1. Gel de agarose 1\%. O marcador usado foi $\lambda$ DNA/Hind III. 


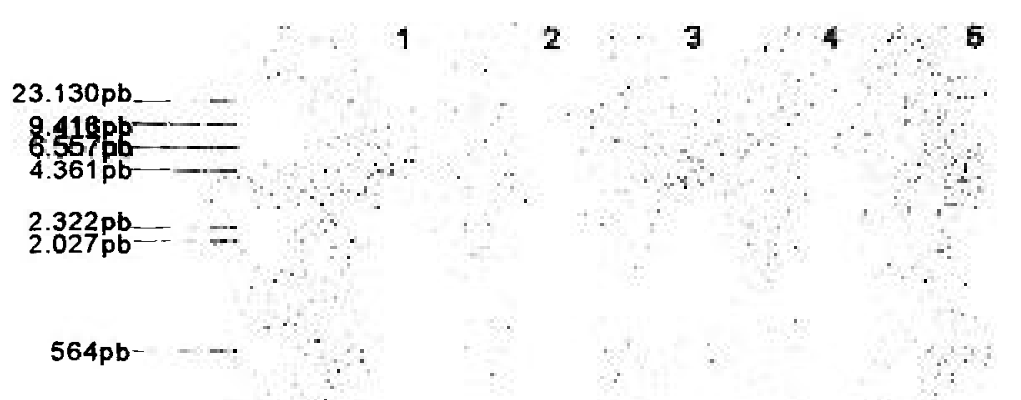

Figura 50: RNA total isolado das amostras célula CHO-K1 dhfr ${ }^{+}$, clones 4 e 8 (CHO-DXB11 x pED-Giro) na presença e ausência de MTX.

1: célula CHO-K1 dhfr ${ }^{+}$(controle negativo); 2-Clone 8 sem MTX, 3-Clone 8 com 20nM MTX, 4- Clone 4 sem MTX, 5- Clone 4 com 20nM MTX.O marcador utilizado foi o $\lambda$ DNA/Hind III. Gel de agarose $1,0 \%$.

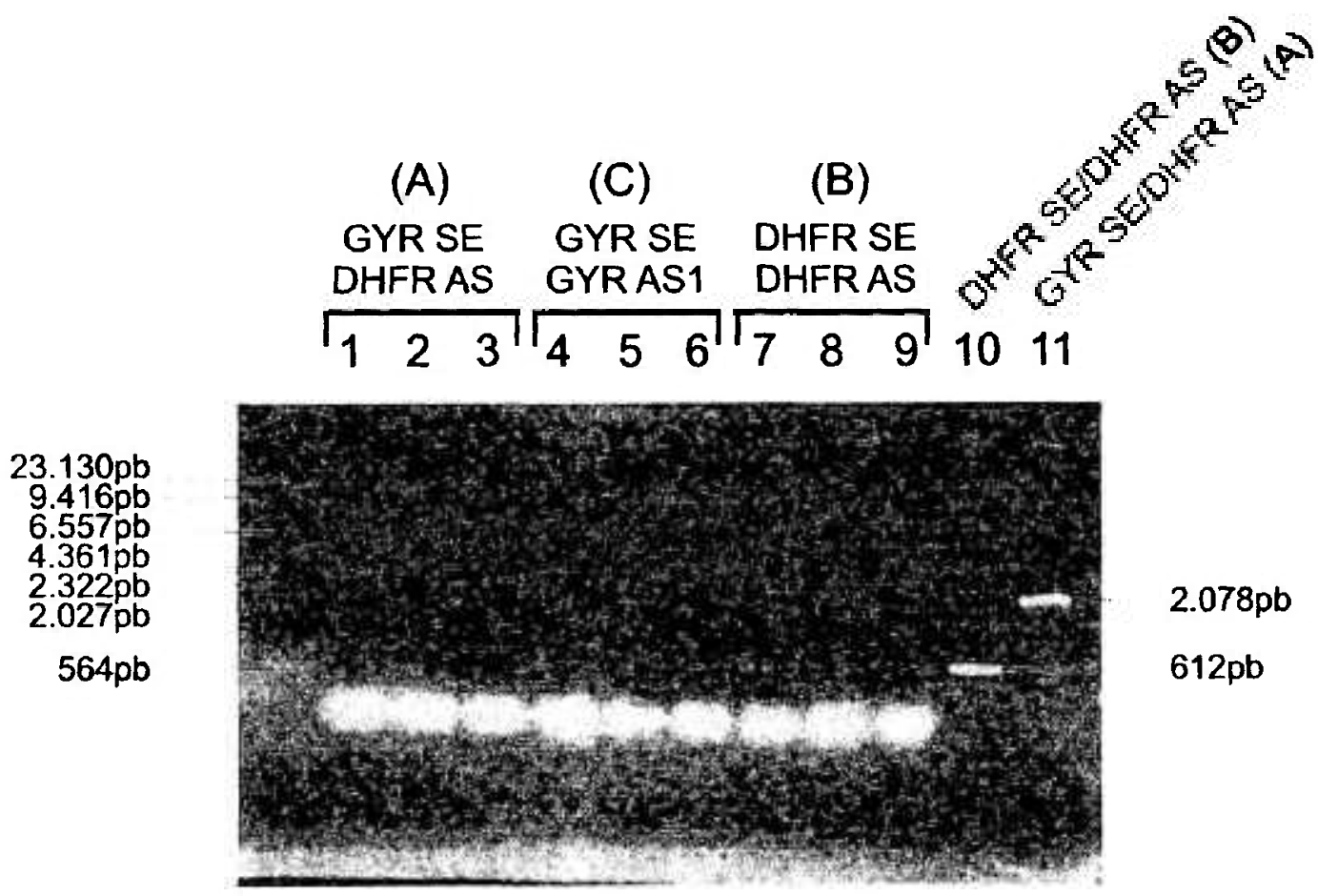

Figura 51: Detecção do mRNA expresso pelos clones 4 e 8 (CHO-DXB11 $x$ pED-Giro) por RT-PCR.

RT-PCR das amostras: CHO-K1 $\mathrm{dhfr}^{+}$(controle negativo) (1, $4 \mathrm{e} 7$ ); clone 4 ( 2,5 e 8); clone 8 (3, 6 e 9); 10 - pED-Giro com primers DHFR SE/AS (B); 11- pED-Giro com os primers GYR SE/DHFR AS (A). Gel de agarose $1,0 \% .0$ marcador usado foi $\lambda \mathrm{DNA} /$ Hind III. 


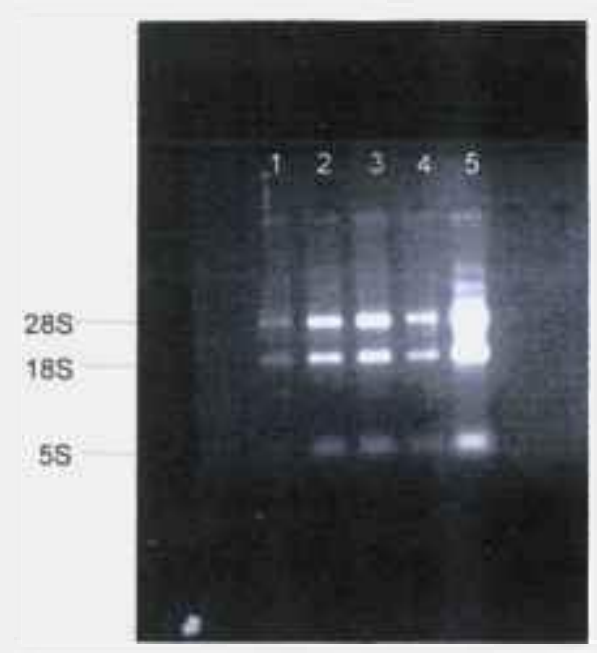

Figura 52: RNA total isolado das amostras clone 4 e 6 na presença e ausência de MTX e célula CHO-DXB11 dhfr.

1-clone 4; 2-clone 6; 3-clone 4 com 20nM MTX; 4- clone 6 com 320nM MTX e 5célula CHO-DXB11 dhfr. Gel de agarose 1\%.Amostras foram diluidas 1:20.

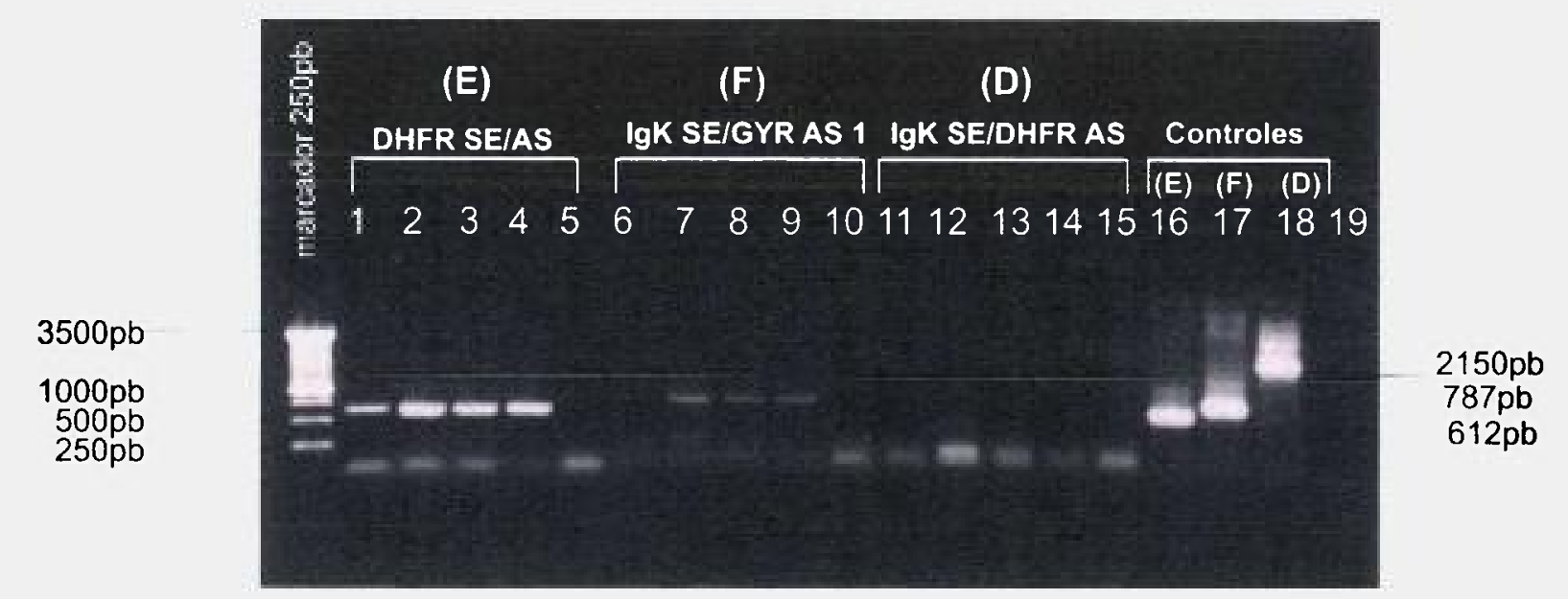

Figura 53: Deteç̧ão do mRNA expresso pelos clones 4 e 6 na ausência e presença de MTX por RT-PCR.

Clone 4 ( 1,6 e 11$)$; clone 4 com 20nM MTX ( 2,7 e 12); clone 6 ( 3,8 e 13$)$; clone 6 com 320nM MTX (4, 9 e 14); CHO DXB11 dhfr (5, 10 e 15); 16- pED-Giro com primers DHFR SE/AS (E); 17-pED-Giro com os primers IgK SE/ GYR AS1 (F); 18pED-Giro com os primers IgK SE/DHFR AS (D); 19- água com os primers IgK SE/ GYR AS1. Gel de agarose 1\%. O marcador usado foi de 250pb. 


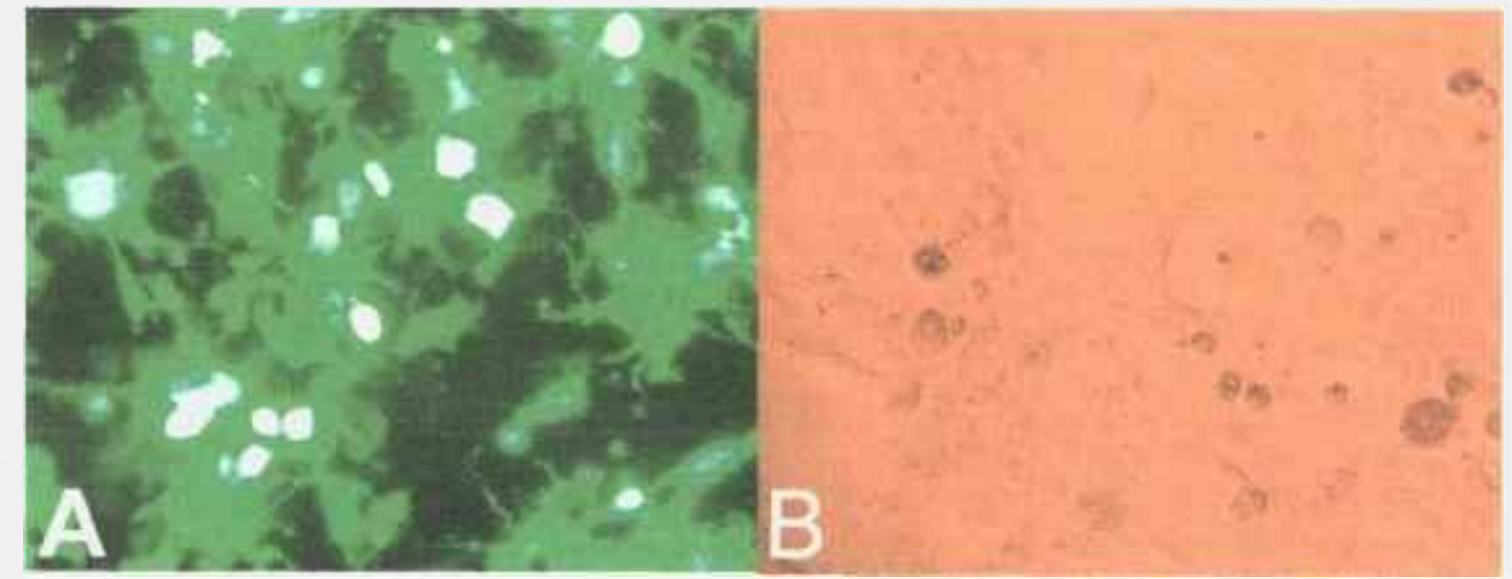

Figura 54: Transfecção da célula COS-7x pED-Giro.

(A) controle da transfeç̧ão com o plasmídeo pEGFP-N1, microscópio de fluorescência detectando as células expressando o GFP. (B) célula COS-7 transfectada com os plasmídeos pED-Giro, aumento de 400x. 
$\begin{array}{llllllll}1 & 2 & 3 & 4 & 5 & 6 & 7 & 8\end{array}$

$\begin{array}{llllllll}1 & 2 & 3 & 4 & 5 & 6 & 7 & 8\end{array}$

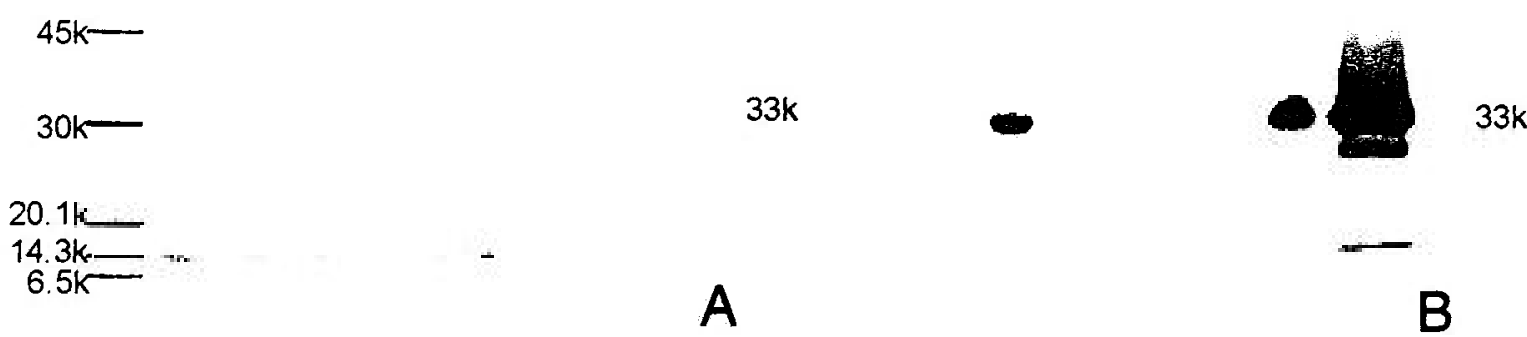

Figura 55: Detecção da proteína recombinante expresso pelo vetor pED-Giro em células Cos-7.

Membrana de nitrocelulose corada com Ponceau S (A) e análise do Westernblot (B) das células COS-7 transfectada com os plasmídeos: 1- padrão de peso molecular Rainbow; 2- pSecTag2-IgK-Giro; 3- pED-Giro; 4- canaleta vazia; 5células COS-7 (controle negativo); 6- canaleta vazia; 7- 500ng de giroxina purificada do veneno $c$. $d$. terrificus (controle positivo); $8-5 \mu g$ de giroxina purificada do veneno da $C$. $d$. Terrificus (controle positivo). $O$ anticorpo pirmário foi o soro anti-crotálico do Instituto Butantan e o anticorpo secundário foi o anti-IgG biotinilada eqüina feito em coelho. 


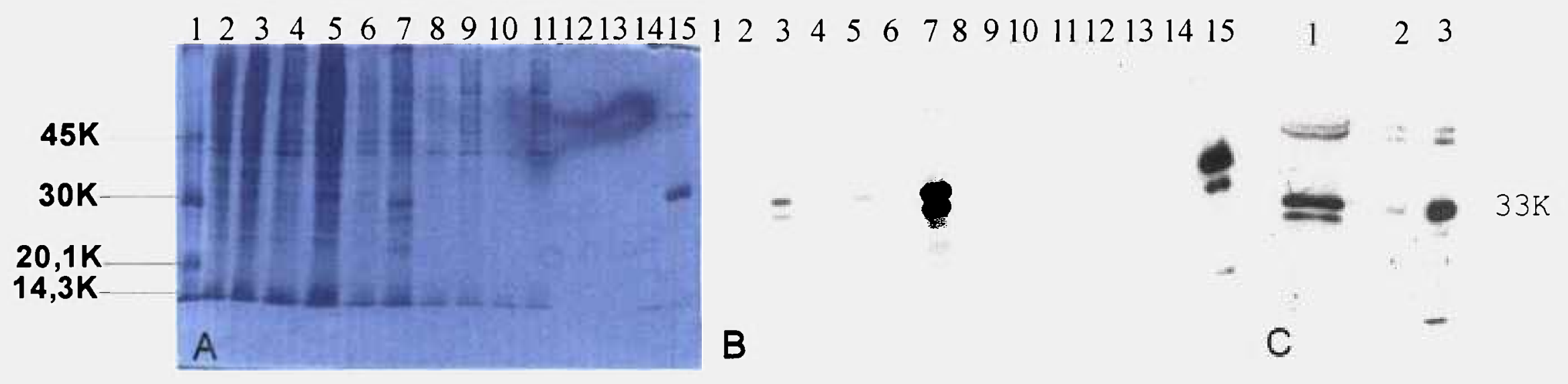

Figura 56: Deteç̧ão da proteína recombinante expressa pelo vetor pED-Giro em células COS-7 e purificada pela resina de afinidade benzamidina sepharose.

(A) Gel de poliacrilamida corada com Comassie Blue e (B) Análise em western blot dos extratos celulares: 1-padrão de peso nolecular Rainbow, 2- extrato celular COS-7 (controle negativo), 3- extrato celular COS-7 transfectada com pED-Giro, 4sobrenadante do lisado da célula sonicada COS-7 (controle negativo), 5- sobrenadante do lisado da célula sonicada cos-7 ransfectada com o pED-Giro, 6-precipitado do lisado da célula sonicada COS-7 (controle negativo), 7- precipitado do lisado da célula cOS-7 transfectada com o pED-Giro, 8- sobrenadante do lisado da célula sonicada COS-7 incubado com a resina (controle negativo), 9- sobrenadante do lisado da célula sonicada COS-7 transfectada com O pED-Giro incubado com a resina, 10sobrenadante do lisado da célula sonicada cos-7 adsorvido a resina (controle negativo), 11- sobrenadante do lisado da célula sonicada COS-7 transfectada com O pED-Giro adsorvido a resina, 12- sobrenadante do lisado da célula sonicada cOS-7 não transfectada eluído da resina, 13- sobrenadante do lisado da célula sonicada COS-7 transfectada com o pED-Giro eluído da resina, 14- $3 \mu \mathrm{g}$ de trispina, $15-3 \mu \mathrm{g}$ de giroxina purificada do veneno. (C): western blot da proteína recombinante purificada do meio de cultura $24 \mathrm{~h}$ após a transfecção da célula COS-7 com o plasmídeo pED-Giro, (2) 50ng de giroxina purificada (controle positivo) e (3) 500 ng de giroxina purificada (controle positivo). 


\section{Atividade Esterásica (5 min)}

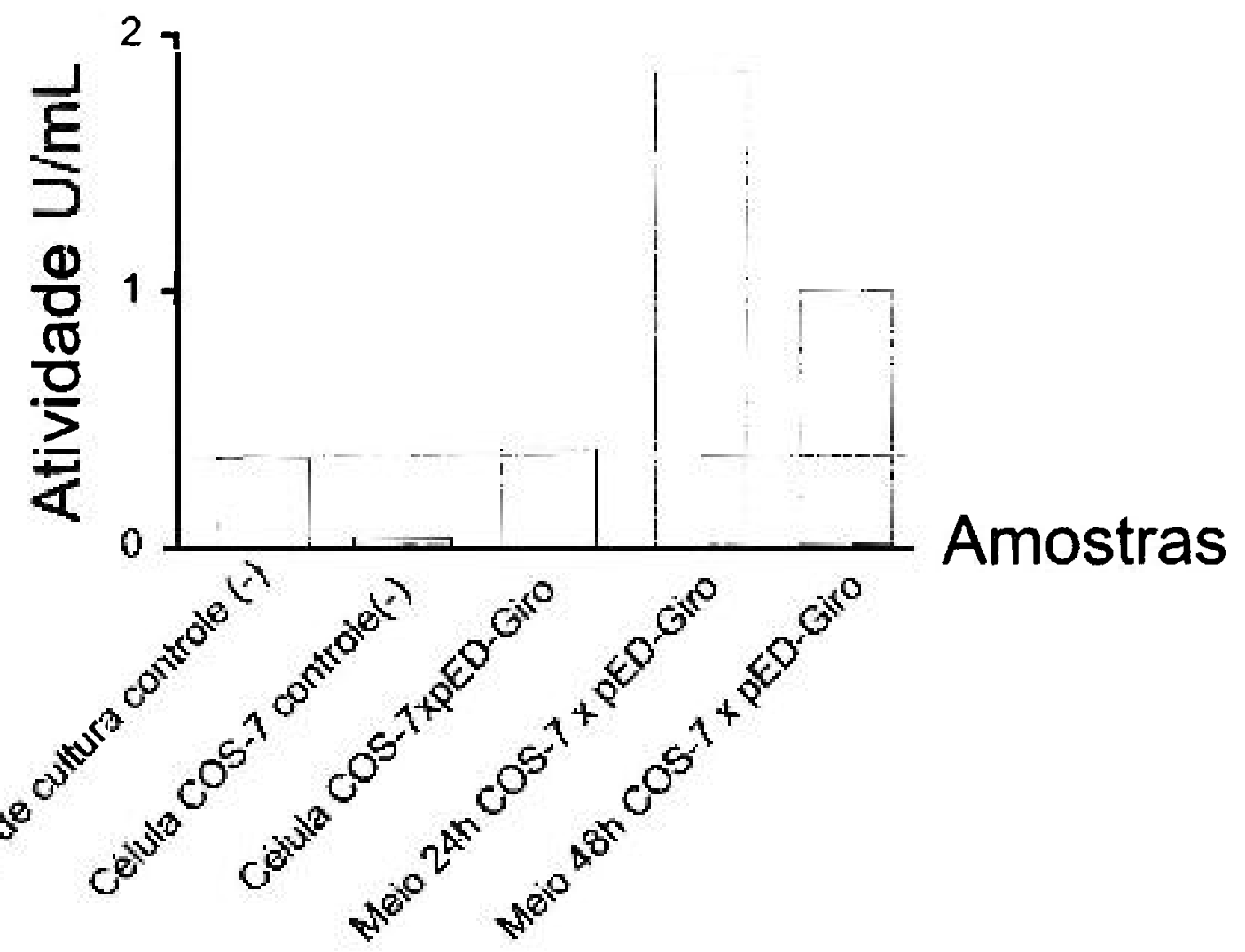

Figura 57: Ensaio de atividade enzimática da giroxina recombinante expresso em COS-7 após a purificação por afinidade em resina benzamidina sepharose. A linha vermelha representa a atividade basal tendo como referência a amostra Meio de cultura controle (-). Teste de atividade esterásica das amostras após a purificação com a resina de afinidade: meio de cultura controle negativo, o sobrenadante do lisado da célula cos-7 (célula cos-7 controle negativo), sobrenadante do lisado da célula COS-7 transfectada com o plasmideo pED-Giro (Célula COS-7 $x$ pED-Giro), meio de cultura $24 \mathrm{~h}$ após a transfecção da célula coS-7 com o plasmídeo pED-Giro (meio 24h COS-7 x pED-Giro), meio de cultura 48h após a transfecção da célula coS-7 com o plasmídeo pED-Giro (meio $48 \mathrm{~h}$ COS-7 x pED-Giro). 
bela 1: Descrição dos vetores.

\begin{tabular}{|c|c|c|c|c|}
\hline Vetor & PCR2, 1 TOPO & $\begin{array}{l}\text { psectag } \\
\text { HygroA }\end{array}$ & pED & (6) \\
\hline Origem & Invitrogen & Invitrogen & $\begin{array}{l}\text { Kauffman, } \\
2000\end{array}$ & Biosciences Clontech \\
\hline Finalidade & $\begin{array}{l}\text { Amplificação/ } \\
\text { Sequenciamento }\end{array}$ & $\begin{array}{l}\text { Expressão/ } \\
\text { Secreção }\end{array}$ & $\begin{array}{l}\text { Expressão/ } \\
\text { Amplificação }\end{array}$ & Expressão \\
\hline Hospedeiro & $\begin{array}{l}\text { E.coli: } \mathrm{DH}^{\mathrm{TM}} \mathrm{a}_{-} \\
\text {T1R ou TOP } 10 .\end{array}$ & $\begin{array}{l}\text { Célula de } \\
\text { mamífero }\end{array}$ & $\begin{array}{l}\text { Célula de } \\
\text { mamífero }\end{array}$ & Célula de mamífero \\
\hline Promotor & T7 & $T 7$ & $\begin{array}{l}\text { Adenovírus } \\
\text { AdMLP }\end{array}$ & Citomegalovírus \\
\hline Resistência & $\begin{array}{l}\text { Ampicilina } \\
\text { Kanamicina }\end{array}$ & $\begin{array}{l}\text { Ampicilina/ } \\
\text { Higromicina }\end{array}$ & Ampicilina & $\begin{array}{l}\text { Kanamicina } \\
\text { Neomicina }\end{array}$ \\
\hline Primers & $\begin{array}{l}\text { M13 sense } \\
\text { M13 antisense }\end{array}$ & $\begin{array}{l}\text { T7 sense } \\
\text { pcDNA3.1/BGH } \\
\text { antisense }\end{array}$ & - & $\begin{array}{l}\text { EGFP-N Sequencing } \\
\text { EGFP-C Sequencing Primer. }\end{array}$ \\
\hline
\end{tabular}


Tabela 2: Descrição dos primers utilizados para clonagem e sequenciamento, mutagênese e RT-PCR. As regiões de hibridação dos primers numerados de 1 a 5 se encontram na figura 29.

\begin{tabular}{|c|c|c|c|c|c|c|}
\hline & $\begin{array}{l}\text { Seqüência } \\
(5 \rightarrow 3)\end{array}$ & $\operatorname{Tm}\left({ }^{\prime \prime} \mathrm{C}\right)$ & Orientaçāo & Finalidade & Regiáto de complementaridade & $\begin{array}{l}\text { Sintese do } \\
\text { primer }\end{array}$ \\
\hline$E$ & GTCATTGGAGGTGATGAATGTAAC & 58 & $\begin{array}{l}\text { Sense } \\
5^{\prime} \rightarrow 3\end{array}$ & $\begin{array}{l}\text { Clonagem } \\
\text { pCR2.1 TOPO } \\
\text { Sequenciamento }\end{array}$ & $\begin{array}{l}\text { Aos } 24 \text { primeiros nucleotídeos da região que } \\
\text { codifica o início do N-terminal da giroxina, } \\
\text { segundo Da Silva et al, } 1988 \text {. }\end{array}$ & Invitrogen \\
\hline $\mathbf{S} 1$ & CGAGGGGCAATTCACAGT & 58 & $\begin{array}{l}\text { Antisense } \\
3^{\prime} \rightarrow 5^{\prime}\end{array}$ & $\begin{array}{l}\text { Clonagem } \\
\text { pCR2.1 TOPO } \\
\text { Sequenciamento }\end{array}$ & $\begin{array}{l}\text { À região de } 697 \text { a } 714 \text { pb que codifica a região } \\
\text { do C-terminal do clone } B 2.1 \text {. }\end{array}$ & Invitrogen \\
\hline so sinal PS & ATGGTGCTGATCAGAGTG & 56 & $\begin{array}{l}\text { Sense } \\
5^{\prime} \rightarrow 3\end{array}$ & \begin{tabular}{|l|} 
Clonagem \\
pCR2.1TOPO \\
Sequenciamento \\
\end{tabular} & $\begin{array}{l}\text { Aos } 18 \text { primeiros nucleotideos que codificam } \\
\text { para o início do peptídeo sinal. }\end{array}$ & IDT-Promega \\
\hline Enese & CATCACCTCCAATGACG TCACCAGIGGAACC & 70 & $\begin{array}{l}\text { Sense } \\
5^{\prime} \rightarrow 3^{\prime}\end{array}$ & Mutagênese & $\begin{array}{l}\text { Aos } 16 \text { primeiros nucleotídeos da região que } \\
\text { codificam o inicio do } \mathrm{N} \text {-terminal do clone } \\
\text { B2.1 (azul) e os } 15 \text { últimos nucleotídeos da } \\
\text { região codificante do peptideo sinal IgK do } \\
\text { vetor pSecTag2 HygroA (vermelho). }\end{array}$ & IDT-Promega \\
\hline$\overline{\mathrm{S} 2}$ & TCAACATGATGTCCTTGT & 52 & $\begin{array}{l}\text { Antisense } \\
3^{\prime} \rightarrow 5^{\prime}\end{array}$ & Sequenciamento & $\begin{array}{l}\text { A região de } 257 \text { a } 274 \mathrm{pb} \text { do clone } \mathrm{B} 2.1 \\
\text { giroxina madura. }\end{array}$ & IDT-Promega \\
\hline$\overline{\mathrm{AS}(5)}$ & CACCTCACCCTAAAACAG & 52 & $\begin{array}{l}\text { Antisense } \\
3^{\prime} \rightarrow 5^{\prime}\end{array}$ & Sequenciamento & Á região de 1006 a 1023pb do clone PST7: 3 & IDT-Promega \\
\hline$\overline{\mathrm{SE}}$ & GCCATCATGGTTCGACCATTGA & 62 & $\begin{array}{l}\text { Sense } \\
5^{\prime} \rightarrow 3^{\prime}\end{array}$ & RT-PCR & $\begin{array}{l}\text { Aos } 22 \text { nucleotídeos que codificam para a } \\
\text { região N-terminal do DHFR, presente no } \\
\text { vetor de expressão pED. }\end{array}$ & ID'T-Promega \\
\hline$\overline{\mathrm{AS}}$ & GATCTAAAGCCAGCAAAAGTC & 54 & $\begin{array}{l}\text { Antisense } \\
3^{\prime} \rightarrow 5^{\prime}\end{array}$ & RT-PCR & $\begin{array}{l}\text { Á região de } 638 \text { a } 658 \mathrm{pb} \text { do C-tenninal do } \\
\text { DHFR, presente no vetor de expressão pED. }\end{array}$ & IDT-Promega \\
\hline o sinal IgK & $\begin{array}{l}\text { ACIGCAGGCT IGCCACCATGGAGACAGACACACTC } \\
\text { Pst I Nhe I }\end{array}$ & 55 & $\begin{array}{l}\text { Sense } \\
5^{\prime} \rightarrow 3^{\prime}\end{array}$ & RT-PCR & $\begin{array}{l}\text { Aos } 18 \text { nucleotideos que codificam para o } \mathrm{N}- \\
\text { terminal do peptideo sinal IgK do vetor } \\
\text { pSecTag2 HygroA. (região sublinhada). }\end{array}$ & DT-Promega \\
\hline
\end{tabular}


Tabela 3. Descrição dos primers universais.

\begin{tabular}{|c|c|c|c|c|c|}
\hline Priner & 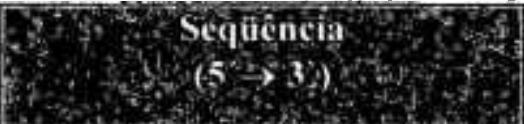 & Tince & Orientacio & Finalidade : & Sintese do \\
\hline M13sense & GTAAAACGACGGCCAG & 53 & $\begin{array}{l}\text { Sense } \\
5^{\prime} \rightarrow 3\end{array}$ & $\begin{array}{l}\text { Clonagem } \\
\text { pCR2.1 TOPO } \\
\text { Sequenciamento }\end{array}$ & Kit pCR2.1Topo \\
\hline $\begin{array}{l}\overline{\mathrm{M}} 13 \\
\text { antisense }\end{array}$ & CAGGAAACAGCTATGAC & 50 & $\begin{array}{l}\text { Antisense } \\
3^{\prime} \rightarrow 5^{\prime}\end{array}$ & $\begin{array}{l}\text { Clonagem } \\
\text { pCR2.1 TOPO } \\
\text { Sequenciamento }\end{array}$ & Kit pCR2.1Topo \\
\hline T3 sense & ATTAACCCTCACTAAAG & 43,8 & $\begin{array}{l}\text { Sense } \\
5^{\prime} \rightarrow 3\end{array}$ & $\begin{array}{l}\text { Clonagem } \\
\text { pCR2.1TOPO } \\
\text { Sequenciamento }\end{array}$ & IDT-Promega \\
\hline $\mathrm{T} 7$ antisense & TAATACGACTCACTATAGG & 50 & $\begin{array}{l}\text { Antisense } \\
3^{\prime} \rightarrow 5^{\prime}\end{array}$ & $\begin{array}{l}\text { Clonagem } \\
\text { pCR2.1 TOPO } \\
\text { Sequenciamento }\end{array}$ & IDT-Promega \\
\hline
\end{tabular}


Tabela 4: Enzimas utilizadas na manipulação de DNA ou RNA.

\begin{tabular}{|c|c|c|c|}
\hline $\begin{array}{c}\text { Enzima } \\
\text { s }\end{array}$ & $\begin{array}{l}\text { Goncentração } \\
\text { da enzima }\end{array}$ & $\begin{array}{l}\text { Concentraçáo } \\
\text { dáreaça }\end{array}$ & Fabricantes \\
\hline Klenow DNA polimerase I & $10 \mathrm{U} / \mu \mathrm{l}$ & $1 \mathrm{U} / \mu \mathrm{g}$ de $\mathrm{DNA}$ & Fermentas \\
\hline Nhe I & $10 \mathrm{U} / \mu \mathrm{l}$ & $1 \mathrm{U} / \mu \mathrm{g}$ de DNA & USB \\
\hline Not I & $10 \mathrm{U} / \mu \mathrm{L}$ & $1 U / \mu g$ de DNA & Jena Bioscience \\
\hline $\begin{array}{l}\text { Inibidor de RNAserecombinante } \\
\text { RNAse OUT) }\end{array}$ & $40 \mathrm{U} / \mu \mathrm{L}$ & $8 \mathrm{U} / / \mu \mathrm{g}$ de $\mathrm{RNA}$ & Invitrogen \\
\hline Sma I & $10 \mathrm{U} / \mu \mathrm{L}$ & $1 \mathrm{U} / \mu \mathrm{g}$ de DNA & Fermentas \\
\hline Spe I & $10 \mathrm{U} / \mu \mathrm{L}$ & $1 \mathrm{U} / \mu \mathrm{g}$ de DNA & Q.Bio gene \\
\hline $\begin{array}{l}\text { SuperScript III (transcriptase } \\
\text { reversa). }\end{array}$ & $200 \mathrm{U} / \mu \mathrm{L}$ & $40 \mathrm{U} / \mu \mathrm{g}$ de RNA & Invitrogen \\
\hline $\begin{array}{l}\text { Taq DNA polymerase } \\
\text { Recombinante }\end{array}$ & $5 \mathrm{U} / \mu \mathrm{L}$ & $0,1 \mathrm{U} / \mu \mathrm{g}$ de DNA & Gibco \\
\hline Taq DNA polymerase Platinum & $5 \mathrm{U} / \mu \mathrm{L}$ & $0,1 \mathrm{U} / \mu \mathrm{g}$ de DNA & Invitrogen \\
\hline T4 DNA ligase & $6,2 \mathrm{U} / \mathrm{mL}$ & $1 \mathrm{U} / \mu \mathrm{g}$ de DNA & Pharmacia \\
\hline T4 polinucleotídeo kinase & $30 \mathrm{U} / \mu \mathrm{L}$ & & USB \\
\hline Xba I & $14 \mathrm{U} / \mu \mathrm{L}$ & $1 \mathrm{U} / \mu \mathrm{g}$ de DNA & USB \\
\hline Xho I & $14 \mathrm{U} / \mu \mathrm{L}$ & $1 \mathrm{U} / \mu \mathrm{g}$ de DNA & Amershan \\
\hline
\end{tabular}


Tabela 5. Descrição das bactérias eletrocompetentes e quimicamente competentes utilizadas.

\begin{tabular}{|c|c|c|c|c|}
\hline Organismo $\cdots$ & Designação. & Genotipo: $\div \quad 1=$ & Aplicacâo : $:$ & Foñte \\
\hline Escherichia coli & TOP10 & 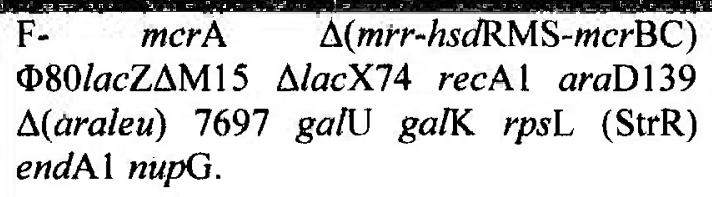 & $\begin{array}{l}\text { Isolamento de clones, } \\
\text { amplificação, sequenciamento. }\end{array}$ & $\begin{array}{l}\text { Catálogo: K4500-01 } \\
\text { TOPO TA Cloning. pCR2.1 } \\
\text { TOPO }\end{array}$ \\
\hline Escherichia coli & DH5a-T1R & $\begin{array}{l}\mathrm{F}-\varphi 80 \text { lacZ } \Delta \mathrm{M} 15 \Delta(\text { lacZYA-rgF)U169 } \\
\text { recA1 endA1 hsdR17(rk-,mk+) phoA } \\
\text { supE44thi-1 gyrA96 relA1 tonA (confere } \\
\text { resistência ao fago } \mathrm{T} 1 \text { ). }\end{array}$ & $\begin{array}{l}\text { Isolamento de clones, } \\
\text { amplificação, sequenciamento. }\end{array}$ & $\begin{array}{l}\text { Catálogo: K4500-01 } \\
\text { TOPO TA Cloning. pCR2.1 } \\
\text { TOPO }\end{array}$ \\
\hline Escherichia coli & Hb101 & $\begin{array}{l}\text { F- supE44 lacY1 ara-14 galK2 xyl-5 mtl-1 } \\
\text { leuB6 delta(mcrC-mrr) recA13 rpsL20 thi-1 } \\
\text { delta(gpt-proA)62 hsdSB20 lambda- }\end{array}$ & $\begin{array}{l}\text { Isolamento de clones, } \\
\text { amplificação, sequenciamento. }\end{array}$ & Número ATCC: $33694^{\mathrm{TM}}$ \\
\hline Escherichia coli & NIH RZ1032 & $\begin{array}{l}\text { lacZbd-279:Tn10 Hfr dut-1 ung-1 derivado } \\
\text { da Escherichia coli } \mathrm{BW} 313\end{array}$ & $\begin{array}{l}\text { DNA de fita simples e } \\
\text { mutagênese. }\end{array}$ & Número ATCC: $39737^{\mathrm{TM}}$ \\
\hline
\end{tabular}


Tabela 6. Análise dos clones pelo software Phred (EWING et al, 1988).

\begin{tabular}{|c|c|c|c|c|}
\hline Clones & $\begin{array}{l}\text { Quantidade de } \\
\text { seqüenciamentos }\end{array}$ & $\begin{array}{c}\text { Total de } \\
\text { Bases }\end{array}$ & $\begin{array}{c}\text { Bases com } \\
\text { qualidade } \\
>20\end{array}$ & $\begin{array}{c}\text { Bases com } \\
\text { qualidade } \\
>30\end{array}$ \\
\hline B2.1 & 1 & 918 & $588(64 \%)$ & $461(50 \%)$ \\
\hline B2.1 & 1 & 906 & $394(43 \%)$ & $245(27 \%)$ \\
\hline B2.1 & 1 & 998 & $521(52 \%)$ & $388(39 \%)$ \\
\hline TOTAL & 3 & 2822 & $1503(53 \%)$ & $1094(39 \%)$ \\
\hline GPS:2 & 1 & 915 & $593(65 \%)$ & $521(57 \%)$ \\
\hline GPS:2 & 1 & 832 & $533(64 \%)$ & $382(46 \%)$ \\
\hline TOTAL & 2 & 1747 & $1126(64,5 \%)$ & $903(51,5)$ \\
\hline GPS: 3 & 1 & 802 & $548(68 \%)$ & $462(58 \%)$ \\
\hline GPS:3 & 1 & 609 & $435(71 \%)$ & $413(68 \%)$ \\
\hline GPS:3 & 1 & 769 & $526(68 \%)$ & $492(64 \%)$ \\
\hline TOTAL & 3 & 2180 & $1509(69 \%)$ & $1367(63 \%)$ \\
\hline GPS:4 & 1 & 770 & $648(84 \%)$ & $570(74 \%)$ \\
\hline GPS:4 & 1 & 816 & $552(68 \%)$ & $471(58 \%)$ \\
\hline TOTAL & 2 & 1586 & $1200(76 \%)$ & $1041(66 \%)$ \\
\hline GPS: 5 & 1 & 902 & $615(68 \%)$ & $534(59 \%)$ \\
\hline GPS: 5 & 1 & 882 & $616(70 \%)$ & $530(60 \%)$ \\
\hline GPS: 5 & 1 & 900 & $637(71 \%)$ & $569(63 \%)$ \\
\hline TOTAL & 3 & 2684 & $1868(70 \%)$ & $1633(61 \%)$ \\
\hline PST7:3 & 1 & 720 & $475(66 \%)$ & $392(54 \%)$ \\
\hline PST7:3 & 1 & 797 & $527(66 \%)$ & $391(49 \%)$ \\
\hline PST7:3 & 1 & 933 & $595(64 \%)$ & $528(57 \%)$ \\
\hline TOTAL & 3 & 2450 & $1597(65 \%)$ & $1311(54 \%)$ \\
\hline PST7:4 & 1 & 873 & $536(61 \%)$ & $388(44 \%)$ \\
\hline PST7:4 & 1 & 879 & $588(67 \%)$ & $516(59 \%)$ \\
\hline TOTAL & 2 & 1752 & $1124(64 \%)$ & $904(51,5 \%)$ \\
\hline PST7:5 & 1 & 826 & $597(72 \%)$ & $507(61 \%)$ \\
\hline PST7:5 & 1 & 901. & $564(63 \%)$ & $474(53 \%)$ \\
\hline TOTAL & 2 & 1727 & $1161(67,5 \%)$ & $981(57 \%)$ \\
\hline PST7:7 & 1 & 784 & $457(58 \%)$ & $340(43 \%)$ \\
\hline PST7:7 & 1 & 814 & $529(65 \%)$ & $367(45 \%)$ \\
\hline PST7:7 & 1 & 950 & $626(66 \%)$ & $534(56 \%)$ \\
\hline TOTAL & 3 & 2548 & $1612(63 \%)$ & $1241(49 \%)$ \\
\hline PST7:8 & 1 & 669 & $546(82 \%)$ & $441(66 \%)$ \\
\hline PST7:8 & 1 & 937 & $276(29 \%)$ & $158(17 \%)$ \\
\hline TOTAL & 2 & 1606 & $822(51 \%)$ & $599(37 \%)$ \\
\hline
\end{tabular}


Tabela 7. Análise de homologia do CDNA do clone B2.1 comparando-se com seqüências do banco de dados do NCBI.

\begin{tabular}{|c|c|c|c|c|}
\hline ID & Produto & Espécie & $\begin{array}{c}\text { Escore } \\
\text { total }\end{array}$ & Identidade \\
\hline D67083.1 & Tlg2b serine protease & Trimeresurus gramineus & 990 & $781 / 895(87 \%)$ \\
\hline U32937.1 & Calobin & Agkistrodon ussuriensis & 974 & $778 / 896(86 \%)$ \\
\hline AF056033.1 & Salmobin & Gloydius halys & 965 & $776 / 894(86 \%)$ \\
\hline U31417.1 & Preprotrimubin & $\begin{array}{l}\text { Trimeresurus } \\
\text { mucrosquamatus }\end{array}$ & 931 & $768 / 891(86 \%)$ \\
\hline AF545576.1 & Stejnobin & Trimeresurus stejnegeri & 920 & $711 / 811(87 \%)$ \\
\hline
\end{tabular}

Tabela 8. Análise de homologia da proteína codificada pelo clone B2.1 comparando-se com seqüências do banco de dados do NCBI.

\begin{tabular}{|c|c|c|c|c|c|}
\hline \multicolumn{6}{|c|}{ 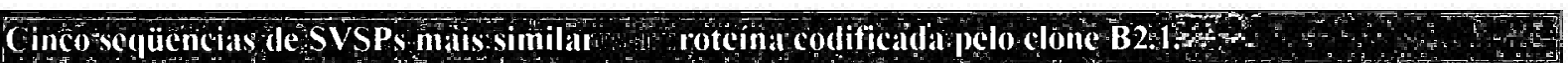 } \\
\hline ID & Produto & Espécie & $\begin{array}{c}\text { Escore } \\
\text { total }\end{array}$ & Identidade & Similaridade \\
\hline Q9PSN3 & Bilineobin & Agkistrodon bilineatus & 404 & $189 / 237(79 \%)$ & $204 / 237(86 \%)$ \\
\hline AAN52347|. & Stejnobin & $\begin{array}{l}\text { Trimeresurus } \\
\text { stejnegeri }\end{array}$ & 398 & $183 / 237(77 \%)$ & $203 / 237(85 \%)$ \\
\hline$\widehat{A A C 13280.1]}$ & Salmobin & Gloydius halys & 392 & $180 / 237(75 \%)$ & $203 / 237(85 \%)$ \\
\hline$\overline{A A C} 61838.1$ & Salmobin & Gloydius halys & 387 & $178 / 237(75 \%)$ & $201 / 237(84 \%)$ \\
\hline$\overline{\mathrm{P} 85109}$ & Serine protease kangshuanmei & $\begin{array}{l}\text { Gloydius blomhoffi } \\
\text { brevicaudus }\end{array}$ & 375 & $177 / 237(74 \%)$ & $199 / 237(83 \%)$ \\
\hline
\end{tabular}


Tabela 9. Análise de homologia do CDNA do clone GSP:2e5 comparando-se com seqüências do banco de dados do NCBI.

\begin{tabular}{|c|c|c|c|c|}
\hline ID & Produto & Espécie & $\begin{array}{c}\text { Escore } \\
\text { total }\end{array}$ & Identidade \\
\hline U32937 & calobin & Agkistrodon ussuriensis & 1075 & $\begin{array}{l}823 / 936 \\
(87 \%)\end{array}$ \\
\hline$\overline{D 67083}$ & TLg2b serine protease. & $\begin{array}{l}\text { Trimeresurus } \\
\text { gramineus }\end{array}$ & 1057 & $\begin{array}{l}829 / 950 \\
(87 \%)\end{array}$ \\
\hline$\overline{\text { AF545576 }}$ & serine protease & $\begin{array}{l}\text { Trimeresurus stejnegeri } \\
\text { stejnobin }\end{array}$ & 1048 & $\begin{array}{l}798 / 907 \\
(87 \%)\end{array}$ \\
\hline EF690366. & thrombin-like serine protease 2 & $\begin{array}{l}\text { Cryptelytrops } \\
\text { albolabris }\end{array}$ & 1035 & $\begin{array}{l}817 / 938 \\
(87 \%)\end{array}$ \\
\hline EF690365. & thrombin-like serine protease 1 & $\begin{array}{l}\text { Cryptelytrops } \\
\text { albolabris }\end{array}$ & 1035 & $\begin{array}{l}815 / 936 \\
(87 \%)\end{array}$ \\
\hline
\end{tabular}

Tabela 10. Análise de homologia da proteína codificada pelo clone GPS:2e5 comparando-se com seqüências do banco de dados do NCBI.

\begin{tabular}{|c|c|c|c|c|c|}
\hline ID & Produto & Espécie & $\begin{array}{c}\text { Escore } \\
\text { total }\end{array}$ & Identidade & Similaridade \\
\hline AAN52347 & stejnobin & \begin{tabular}{|l} 
Trimeresurus \\
stejnegeri
\end{tabular} & 446 & $207 / 261(79 \%)$ & $228 / 261(87 \%)$ \\
\hline$\overline{\mathrm{AAC} 13280}$ & salmobin & Gloydius halys & 436 & $203 / 261(77 \%)$ & $227 / 261(87 \%)$ \\
\hline AAC61838 & salmobin & Gloydius halys & 433 & $202 / 261(77 \%)$ & $226 / 261(86 \%)$ \\
\hline$\overline{A B S 12075}$ & thrombin-like serine protease 2 & $\begin{array}{l}\text { Cryptelytrops } \\
\text { albolabris }\end{array}$ & 419 & $204 / 261(78 \%)$ & $226 / 261(86 \%)$ \\
\hline ABS12074. & thrombin-like serine protease 1 & $\begin{array}{l}\text { Cryptelytrops } \\
\text { albolabris }\end{array}$ & 419 & $204 / 261(78 \%)$ & $227 / 261(86 \%)$ \\
\hline
\end{tabular}


Tabela11. Análise de homologia do CDNA do clone GSP:3e4 comparando-se com seqüências do banco de dados do NCBI.

\begin{tabular}{|c|c|c|c|c|}
\hline ID & Produto & Espécie & $\begin{array}{l}\text { Escore } \\
\text { total }\end{array}$ & Identidade \\
\hline $\begin{array}{l}\text { EF690366.1 } \\
\end{array}$ & $\begin{array}{l}\text { thrombin-like serine } \\
\text { protease } 2\end{array}$ & Cryptelytrops albolabris & 1101 & $827 / 936(88 \%)$ \\
\hline $\begin{array}{l}\text { EF690365.1 } \\
\end{array}$ & $\begin{array}{l}\text { thrombin-like serine } \\
\text { protease } 1\end{array}$ & Cryptelytrops albolabris & 1101 & $825 / 934(88 \%)$ \\
\hline D67083 & TLg2b serine protease. & Trimeresurus gro & 1088 & $838 / 955(87 \%)$ \\
\hline AF545576 & serine protease & $\begin{array}{l}\text { Trimeresurus stejnegeri } \\
\text { stejnobin }\end{array}$ & 1075 & $802 / 906(88 \%)$ \\
\hline U32937 & calobin & Agkistrodon ussuriensis & 1062 & $827 / 944(87 \%)$ \\
\hline
\end{tabular}

Tabela 12. Análise de homologia da proteína codificada pelo clone GPS: $3 e 4$ comparando-se com seqüências do banco de dados do NCBI.

\begin{tabular}{|c|c|c|c|c|c|}
\hline \multicolumn{5}{|c|}{ 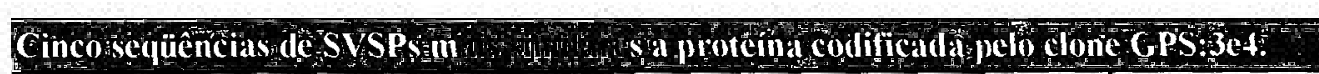 } & \multirow[b]{2}{*}{ Similaridade } \\
\hline $\mathbf{D D}$ & Produto & Espécie & $\begin{array}{l}\text { Escore } \\
\text { total }\end{array}$ & Identidade & \\
\hline AAN52347 & stejnobin & Trimeresurus stejnegeri & 449 & $209 / 261(80 \%)$ & $228 / 261(87 \%)$ \\
\hline AAC13280. & salmobin & Gloydius halys & 435 & $204 / 261(78 \%)$ & $225 / 261(86 \%)$ \\
\hline AAC61838 & salmobin & Gloydius halys & 432 & $203 / 261(77 \%)$ & $224 / 261(85 \%)$ \\
\hline ABS12075 & thrombin-like serine protease 2 & Cryptelytrops albolabris & 432 & $210 / 261(80 \%)$ & $229 / 261(87 \%)$ \\
\hline$\overline{A B S 12074 .}$ & thrombin-like serine protease 1 & Cryptely & 431 & $210 / 261(80 \%)$ & $230 / 261(88 \%)$ \\
\hline
\end{tabular}


Tabela 13. Análise de homologia do CDNA do clone PST7:3 comparando-se com seqüências do banco de dados do NCBI.

\begin{tabular}{|c|c|c|c|c|}
\hline ID & Produto & Espécie & $\begin{array}{c}\text { Escore } \\
\text { total }\end{array}$ & Identidade \\
\hline D67083.1 & TLg2b serine protease & Trimeresurus gramineus & 1792 & $\begin{array}{l}1268 / 1408 \\
(90 \%)\end{array}$ \\
\hline U32937.1 & calobin & Agkistrodon ussuriensis & 1781 & $\begin{array}{l}1286 / 1438 \\
(89 \%)\end{array}$ \\
\hline U31417.1 & preprotrimubin & $\begin{array}{l}\text { Trimeresurus } \\
\text { mucrosquamatus }\end{array}$ & 1746 & $\begin{array}{l}1266 / 1416 \\
(89 \%)\end{array}$ \\
\hline$\overline{D 67082.1}$ & TLg2a serine protease & Trimeresurus gramineus & 1690 & $\begin{array}{l}1260 / 1421 \\
(88 \%)\end{array}$ \\
\hline$\overline{\mathrm{D} 67080.1}$ & TLf3 serine protease & Trimeresurus flavoridis & 1681 & $\begin{array}{l}1254 / 1415 \\
(88 \%)\end{array}$ \\
\hline
\end{tabular}

Tabela 14. Análise de homologia da proteína codificada pelo clone PST7:3 comparando-se com seqüências do banco de dados do NCBI.

\begin{tabular}{|c|c|c|c|c|c|}
\hline ID & Produto & Espécie & $\begin{array}{l}\text { Escore } \\
\text { total }\end{array}$ & Identidade & Similaridade \\
\hline$\overline{\text { AAN52347 }}$ & stejnobin & Trimeresurus stejnegeri & 449 & $208 / 261(79 \%)$ & $229 / 261(87 \%)$ \\
\hline$\overline{A A C 13280}$ & salmobin & Gloydius halys & 438 & $204 / 261(78 \%)$ & $228 / 261(87 \%)$ \\
\hline$\overline{\text { AAC61838 }}$ & salmobin & Gloydius halys & 436 & $203 / 261(77 \%)$ & $227 / 261(86 \%)$ \\
\hline ABS12075 & thrombin-like serine protease 2 & Cryptelytrops albolabris & $\longdiv { 4 2 2 }$ & $205 / 261(78 \%)$ & $227 / 261(86 \%)$ \\
\hline ABS12074. & thrombin-like serine protease 1 & Cryptelytrops albolabris & 422 & $205 / 261(80 \%)$ & $2228 / 261(87 \%)$ \\
\hline
\end{tabular}


Tabela 15. Análise de homologia do CDNA do clone PST7:4 comparando-se com seqüências do banco de dados do NCBI.

\begin{tabular}{|c|c|c|c|c|}
\hline ID & Produto & Espécie & Total Score & Identidade \\
\hline$\overline{\mathrm{D} 67083.1}$ & TLg2b serine protease. & Trimeresurus gramineus & 1853 & $\begin{array}{l}1279 / 1408 \\
(90 \%),\end{array}$ \\
\hline U32937.1 & calobin & Agkistrodon ussuriensis & 1792 & $\begin{array}{l}1291 / 1441 \\
(89 \%)\end{array}$ \\
\hline U31417.1 & preprotrimubin & $\begin{array}{l}\text { Trimeresurus } \\
\text { mucrosquamatus }\end{array}$ & 1790 & $\begin{array}{l}1273 / 1414 \\
(90 \%),\end{array}$ \\
\hline$\overline{\mathrm{D}} 67082.1$ & TLg2a serine protease & Trimeresurus gramineus & 1722 & $\begin{array}{l}1268 / 1423 \\
(89 \%)\end{array}$ \\
\hline D67080.1 & TLf3 serine protease & Trimeresurus flovoridis & 1701 & $\begin{array}{l}1259 / 1416 \\
(88 \%),\end{array}$ \\
\hline
\end{tabular}

Tabela 16. Análise de homologia da proteína codificada pelo clone PST7:4 comparando-se com seqüências do banco de dados do NCBI.

\begin{tabular}{|c|c|c|c|c|c|}
\hline ID & Produto & Espécie & $\begin{array}{l}\text { Total } \\
\text { Score }\end{array}$ & Identidade & Similaridade \\
\hline AAN52347. & stejnobin & Trimeresurus stejnegeri & 449 & $209 / 262(79 \%)$ & $228 / 262(87 \%)$ \\
\hline $\mathrm{AAC13280}$. & salmobin & Gloydius halys & 437 & $205 / 262(78 \%)$ & $226 / 262(86 \%)$ \\
\hline AAC61838 & salmobin & Gloydius halys & 434 & $204 / 262(77 \%)$ & $225 / 262(85 \%)$ \\
\hline ABS12075 & thrombin-like serine protease 2 & Cryptelytrops albolabris & 4 & $210 / 262(80 \%)$ & $229 / 262(87 \%)$ \\
\hline ABS12074. & thrombin-like serine protease 1 & Cryptelytrops albolabris & 431 & $210 / 262(80 \%)$ & $230 / 262(87 \%)$ \\
\hline
\end{tabular}


Tabela 17. Análise de homologia do CDNA do clone PST7:7e8 comparando-se com seqüências do banco de dados do NCBI.

\begin{tabular}{|l|l|l|l|l|}
\hline Cingosgind & Espécie & $\begin{array}{l}\text { Total } \\
\text { Score }\end{array}$ & Identidade \\
\hline UD & Produto & $\begin{array}{l}\text { Trimeresurus } \\
\text { mucrosquamatus }\end{array}$ & $\begin{array}{l}1281 / 1399 \\
(91 \%)\end{array}$ \\
\hline U32937.1 & calobin & Agkistrodon ussuriensis & 1857 & $\begin{array}{l}1294 / 1430 \\
(90 \%)\end{array}$ \\
\hline D67080.1 & TLf3 serine protease & Trimeresurus flavoridis & 1812 & $\begin{array}{l}1268 / 1403 \\
(90 \%)\end{array}$ \\
\hline D67082.1 & TLg2a serine protease & Trimeresurus gramineus & 1783 & $\begin{array}{l}1272 / 1414 \\
(89 \%)\end{array}$ \\
\hline AF336126 & $\begin{array}{l}\text { thrombin-like serine } \\
\text { protease }\end{array}$ & Gloydius ussuriensis & 1779 & $\begin{array}{l}1269 / 1411 \\
(89 \%)\end{array}$ \\
\hline
\end{tabular}

Tabela 18. Análise de homologia da proteína codificada pelo clone PST7:7e8 comparando-se com seqüências do banco de dados do NCBI.

\begin{tabular}{|c|c|c|c|c|c|}
\hline ID & Produto & Espécie & $\begin{array}{l}\text { Total } \\
\text { Score }\end{array}$ & Identidade & Similaridade \\
\hline AAQ02904 & serine protease CL5 & $\begin{array}{l}\text { Trimeresurus } \\
\text { stejnegeri }\end{array}$ & $\longdiv { 4 3 2 }$ & $206 / 259(79 \%)$ & $\begin{array}{l}219 / 259 \\
(84 \%)\end{array}$ \\
\hline$\overline{\mathrm{AAF} 25008}$ & salmonase & $\begin{array}{l}\text { Gloydius halys } \\
\text { brevicaudus }\end{array}$ & 429 & $205 / 259(77 \%)$ & $\begin{array}{l}220 / 259 \\
(84 \%)\end{array}$ \\
\hline AAQ02909.1 & serine protease CL4 & $\begin{array}{l}\text { Trimeresurus } \\
\text { stejnegeri }\end{array}$ & 425 & $201 / 258(77 \%)$ & $\begin{array}{l}217 / 258 \\
(84 \%)\end{array}$ \\
\hline Q9PTU8 & Protease A & Bothrops jararaca & 4 & $202 / 260(77 \%)$ & $\begin{array}{l}219 / 260 \\
(84 \%)\end{array}$ \\
\hline AF370124_1 & thrombin-like enzyme & Gloydius ussuriensis & 412 & $199 / 262(75 \%)$ & $\begin{array}{l}219 / 262 \\
(83 \%)\end{array}$ \\
\hline
\end{tabular}


Tabela 19. Análise de homologia do CDNA do clone PST7:5 comparando-se com seqüências do banco de dados do NCBI.

\begin{tabular}{|c|c|c|c|c|}
\hline ID & Produto & Espécie & $\begin{array}{c}\text { Escore } \\
\text { total }\end{array}$ & Identidade \\
\hline |D67083.1| & TL $2 \mathrm{~b}$ serine protease & Trimeresurus gramineus & 1206 & $743 / 786(94 \%)$ \\
\hline U32937.1 & preprotrimubin & $\begin{array}{l}\text { Trimeresurus } \\
\text { mucrosquamatus }\end{array}$ & 1194 & $745 / 791(94 \%)$ \\
\hline U32937 & calobin & Agkistrodon ussuriensis & 1188 & $755 / 808(93 \%)$ \\
\hline$\overline{\mathrm{D} 67082.1}$ & TLg2a serine protease & Trimeresurus gramineus & 1177 & $741 / 790(93 \%)$ \\
\hline$\overline{\mathrm{D} 67080.1}$ & TLf3 serine protease & Trimeresurus flavoviridis & 1166 & $737 / 788(93 \%)$ \\
\hline
\end{tabular}

Tabela 20: Análise de homologia da proteína codificada pelo clone PST7:5 comparando-se com seqüéncias do banco de dados do NCBI.

\begin{tabular}{|l|l|l|l|l|l|}
\hline Gifcosed & & \\
\hline ID & Produto & Espécie & $\begin{array}{c}\text { Escore } \\
\text { total }\end{array}$ & & \\
\hline AAC61838 & salmobin & Gloydius halys & 275 & $131 / 164(79 \%)$ & $144 / 164(87 \%)$ \\
\hline AAN52347. & stejnobin & Trimeresurus stejnegeri & 274 & $128 / 163(78 \%)$ & $144 / 163(88 \%)$ \\
\hline AAC13280. & salmobin & Gloydius halys & 272 & $130 / 164(79 \%)$ & $143 / 164(87 \%)$ \\
\hline ABS12075 & thrombin-like serine protease 2 & Cryptelytrops albolabris & 251 & $129 / 163(79 \%)$ & $144 / 163(88 \%)$ \\
\hline ABS12074. & thrombin-like serine protease 1 & Cryptelytrops albolabris & 251 & $128 / 163(78 \%)$ & $143 / 163(87 \%)$ \\
\hline
\end{tabular}


Tabela 21. Análise da organização dos CDNAs Giroxina símile em relação ao gene de Batroxobin.

\begin{tabular}{|c|c|c|c|c|c|c|}
\hline \multirow{2}{*}{$\begin{array}{c}\text { Gene } \\
\text { x } \\
\text { cDNA }\end{array}$} & $\begin{array}{l}\text { Exon } 1 \\
240 \text { bp }\end{array}$ & $\begin{array}{l}\text { Exon } 2 \\
151 \text { bp }\end{array}$ & $\begin{array}{l}\text { hrom } 3 \\
260 \text { bp }\end{array}$ & $\begin{array}{l}\text { Erou } 4 \\
134 \text { bp }\end{array}$ & $\begin{array}{l}\text { Exon } 5 \\
728 \text { bp }\end{array}$ & \multirow{2}{*}{$\begin{array}{l}\text { Batroxobin } \\
\text { Coordenadas }\end{array}$} \\
\hline & $\begin{array}{c}\text { S'UTR/ATG/PS } \\
101-340\end{array}$ & $\begin{array}{l}\text { PS/Toxina } \\
2860-3010\end{array}$ & $\begin{array}{c}\text { Toxina } \\
4775-5034\end{array}$ & $\begin{array}{c}\text { Toxina } \\
6821-6954\end{array}$ & $\begin{array}{c}\text { Toxina/stop/3'UTR } \\
7296-8023\end{array}$ & \\
\hline Batroxobin & $\begin{array}{c}110-340 \\
1-231 \\
231 \mathrm{bp} \\
100.0 \% \\
0 \\
0 \\
\end{array}$ & $\begin{array}{c}2860-3010 \\
232-382 \\
151 \mathrm{bp} \\
100.0 \% \\
0 \\
0\end{array}$ & $\begin{array}{c}4775-5016 \\
383-624 \\
242 \text { bp } \\
99.6 \% \\
1 \\
0\end{array}$ & $\begin{array}{c}6803-6959 \\
625-781 \\
157 \mathrm{bp} \\
90.4 \% \\
15 \\
0\end{array}$ & $\begin{array}{c}7301-8023 \\
782-1504 \\
723 \mathrm{bp} \\
99.9 \% \\
1 \\
0\end{array}$ & $\begin{array}{l}\text { Cenduico } \\
\text { mRNA } \\
\text { Tamanho } \\
\text { ldentidade } \\
\text { Conflitos } \\
\text { Delecodes }\end{array}$ \\
\hline B2:1 & & $\begin{array}{c}2880-3010 \\
1-137 \\
137 \mathrm{bp} \\
76.6 \% \\
32 \\
6\end{array}$ & $\begin{array}{c}775-5016 \\
138-379 \\
242 \text { bp } \\
74.4 \% \\
62 \\
0\end{array}$ & $\begin{array}{c}6803-6959 \\
380-548 \\
169 \mathrm{bp} \\
68.6 \% \\
53 \\
12 \\
\end{array}$ & $\begin{array}{c}7301-7631 \\
549-881 \\
333 \mathrm{bp} \\
88.0 \% \\
40 \\
4 \\
\end{array}$ & $\begin{array}{l}\text { Genômico } \\
\text { mRNA } \\
\text { Tamanho } \\
\text { Identidade } \\
\text { Conflitos } \\
\text { Deleçdes } \\
\end{array}$ \\
\hline GPS:2e5 & $\begin{array}{c}107-340 \\
31-264 \\
234 \mathrm{bp} \\
90.6 \% \\
22 \\
0\end{array}$ & $\begin{array}{c}2860-3010 \\
265-421 \\
157 \mathrm{bp} \\
79.0 \% \\
33 \\
6\end{array}$ & $\begin{array}{c}4775-5016 \\
422-663 \\
242 \mathrm{bp} \\
74.4 \% \\
62 \\
0\end{array}$ & $\begin{array}{c}6803-6959 \\
664-832 \\
169 \mathrm{bp} \\
68.6 \% \\
53 \\
12\end{array}$ & $\begin{array}{c}7301-7469 \\
833-1001 \\
169 \text { bp } \\
84.0 \% \\
27 \\
0\end{array}$ & $\begin{array}{l}\text { Genómico } \\
\text { mRNA } \\
\text { Tamanho } \\
\text { Identidade } \\
\text { Conflitos } \\
\text { Deleços }\end{array}$ \\
\hline GPS:3e4 & $\begin{array}{c}102-340 \\
1-239 \\
239 \text { bp } \\
87.9 \% \\
29 \\
0\end{array}$ & $\begin{array}{c}2860-3010 \\
240-396 \\
157 \text { bp } \\
79.0 \% \\
33 \\
6\end{array}$ & $\begin{array}{c}4775-5038 \\
397-660 \\
264 \mathrm{bp} \\
73.9 \% \\
69 \\
0\end{array}$ & $\begin{array}{c}6825-6959 \\
661-807 \\
147 \mathrm{bp} \\
74.1 \% \\
38 \\
12\end{array}$ & $\begin{array}{c}7301-7469 \\
808-976 \\
169 \text { bp } \\
86.4 \% \\
23 \\
0\end{array}$ & $\begin{array}{l}\text { Genômico } \\
\text { mRNA } \\
\text { Tamanho } \\
\text { Identidade } \\
\text { Conflitos } \\
\text { Deleçðes }\end{array}$ \\
\hline PST7:3 & $\begin{array}{c}289-340 \\
1.52 \\
52 \mathrm{bp} \\
94.2 \% \\
3 \\
0\end{array}$ & $\begin{array}{c}2860-3010 \\
53-209 \\
157 \mathrm{bp} \\
79.0 \% \\
33 \\
6\end{array}$ & $\begin{array}{c}4775-5016 \\
210-451 \\
242 \mathrm{bp} \\
74.4 \% \\
62 \\
0\end{array}$ & $\begin{array}{c}6803-6959 \\
452-620 \\
169 \mathrm{bp} \\
68.6 \% \\
53 \\
12 \\
\end{array}$ & $\begin{array}{c}7301-8024 \\
621-1401 \\
781 \mathrm{bp} \\
83.9 \% \\
126 \\
61 \\
\end{array}$ & $\begin{array}{l}\text { Genómico } \\
\text { mRNA } \\
\text { Tamanho } \\
\text { Identidade } \\
\text { Conflitos } \\
\text { Delegores } \\
\end{array}$ \\
\hline PST7:4 & $\begin{array}{c}289-340 \\
1.52 \\
52 \mathrm{bp} \\
94.2 \% \\
3 \\
0\end{array}$ & $\begin{array}{c}2860-3010 \\
53-209 \\
157 \text { bp } \\
78.3 \% \\
34 \\
6\end{array}$ & $\begin{array}{c}4775-5038 \\
210-473 \\
264 \mathrm{bp} \\
73.9 \% \\
69 \\
0\end{array}$ & $\begin{array}{c}6825-6959 \\
474-620 \\
147 \mathrm{bp} \\
74.1 \% \\
38 \\
12\end{array}$ & $\begin{array}{c}7301-8022 \\
621-1400 \\
780 \mathrm{bp} \\
84.6 \% \\
120 \\
60\end{array}$ & $\begin{array}{l}\text { Genômico } \\
\text { mRNA } \\
\text { Tamanho } \\
\text { Identidade } \\
\text { Conflitos } \\
\text { Deleçðes }\end{array}$ \\
\hline PST7:5 & $\begin{array}{c}289-340 \\
1-52 \\
52 \mathrm{bp} \\
94.2 \% \\
3 \\
0\end{array}$ & $\begin{array}{c}2860-3010 \\
53-209 \\
157 \text { bp } \\
79.0 \% \\
33 \\
6\end{array}$ & $\begin{array}{c}4775-5034 \\
210-469 \\
260 \\
74.6 \% \\
66 \\
0\end{array}$ & & $\begin{array}{c}7296-8022 \\
470-1255 \\
786 \text { bp } \\
84.4 \% \\
123 \\
63\end{array}$ & $\begin{array}{l}\text { Genômico } \\
\text { mRNA } \\
\text { Tumulas } \\
\text { Identidade } \\
\text { Conflitos } \\
\text { Delocoes }\end{array}$ \\
\hline PST7:7e8 & $\begin{array}{c}289-340 \\
1-52 \\
52 \mathrm{bp} \\
94.2 \% \\
3 \\
0\end{array}$ & $\begin{array}{c}2860-3010 \\
53-200 \\
148 \text { bp } \\
83.1 \% \\
25 \\
3\end{array}$ & $\begin{array}{c}4775-5034 \\
201-460 \\
260 \mathrm{bp} \\
78.8 \% \\
55 \\
0\end{array}$ & $\begin{array}{c}6821-6959 \\
461-611 \\
151 \mathrm{bp} \\
78.1 \% \\
33 \\
12\end{array}$ & $\begin{array}{c}7301-8020 \\
612-1389 \\
778 \mathrm{bp} \\
84.1 \% \\
124 \\
62\end{array}$ & $\begin{array}{l}\text { Genómico } \\
\text { mRNA } \\
\text { Tamanho } \\
\text { ldentidade } \\
\text { Conflitos } \\
\text { Deleçőes }\end{array}$ \\
\hline
\end{tabular}


Tabela 22: Similaridades em porcentagem entre as seqüências de CDNA dos clones de B2.1, GPS:2e5, GPS:3e4, PST7:3, PST7:4, PST7:5 e PST7:7e8.

\begin{tabular}{|c|c|c|c|c|c|c|c|}
\hline & B21. & GPS: $2 \mathrm{e}$ & GPS: $3 \mathrm{e} 4$ & PSTR & PST 74 & PST7.5 & PST $7.7 \mathrm{e} 8$ \\
\hline & 100,00 & 99,58 & 94,16 & 99,55 & 94,40 & 94,86 & 84,04 \\
\hline$G P S: 2 e^{\circ}$ & 99,58 & 100,00 & 96,09 & 99,87 & 94,72 & 95,16 & 83,21 \\
\hline GPS? 3 & 94,16 & 96,09 & 100,00 & 95,26 & 99,62 & 99,69 & 83,40 \\
\hline PST 7 & 99,55 & 99,87 & 95,26 & 100,00 & 96,14 & 96,67 & 88,45 \\
\hline & 94,40 & 94,72 & 99,62 & 96,14 & 100,00 & 99,76 & 88,57 \\
\hline & 94,86 & 95,16 & 99,69 & 96,67 & 99,76 & 100,00 & 89,57 \\
\hline PST 778 & 84,04 & 83,21 & 83,40 & 88,45 & 88,57 & 89,57 & 100,00 \\
\hline
\end{tabular}

Tabela 23: Similaridade em porcentagem das toxinas maduras dos clones B2.1, GPS:2e5, GPS:3e4, PST7:3, PST7:4, PST7:7e8.

\begin{tabular}{|c|c|c|c|c|c|c|}
\hline & B2.1. & GPS: 2 & GP & PST & 2577.4 & PST7 \\
\hline B2:1: & 100,00 & 99,15 & 92,0 & 98,73 & 91,56 & 77,21 \\
\hline GPS $2 \mathrm{e} 5$ & 99,15 & 100,00 & 92,85 & 99,57 & 92,01 & 78,15 \\
\hline GPS: 3 e 4 & 92,00 & 92,85 & 100,00 & 93,27 & 99,57 & 77,31 \\
\hline PST $7: 3$ & 98,73 & 99,57 & 93,27 & 100,00 & 92,82 & 78,48 \\
\hline PST7: 4 & 91,56 & 92,01 & 99,57 & 92,82 & 100,00 & 77,73 \\
\hline PST7 7 e 8 & 77,21 & 78,15 & 77,31 & 78,48 & 77,73 & 100,00 \\
\hline
\end{tabular}


Tabela 24: Seqüências homólogas com mais alto escore de similaridade em relação à toxina madura codificada pelos clones B2.1, GPS:2e5, GPS:3e4,PST7:3, PST7:4, PST7:7e8.

\begin{tabular}{|c|c|c|c|c|c|c|}
\hline \multicolumn{2}{|c|}{ 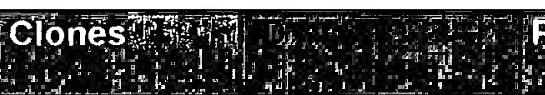 } & \multirow{2}{*}{$\begin{array}{l}\text { Produto } \\
\text { Bilineobin } \\
\text { Bis }\end{array}$} & \multirow{2}{*}{$\begin{array}{l}\text { Esisclet } \\
\text { Agkistrodon bilineatus }\end{array}$} & Fecore otal & Tdentidade $x_{r}$ & \multirow{2}{*}{$\begin{array}{l}\text { Similaridade } \\
204 / 237(86 \%)\end{array}$} \\
\hline B2.1 & Q9PSN3 & & & 404 & $189 / 237(79 \%)$ & \\
\hline GPS: 2 e 5 & Q9PSN3 & Bilineobin & Agkistrodon bilineatus & 408 & $190 / 237(80 \%)$ & $205 / 237(86 \%)$ \\
\hline GPS:3 e 4 & AAN52347 & Stejnobin & Trimeresurus stejnegeri & 405 & $186 / 237(78 \%)$ & $204 / 237(86 \%)$ \\
\hline PST7:3 & Q9PSN3 & Bilineobin & Agkistrodon bilineatus & 406 & $190 / 237(80 \%)$ & $205 / 237(86 \%)$ \\
\hline PST7:4 & AAN52347 & Stejnobin & Trimeresurus stejnegeri & 405 & $186 / 238(78 \%)$ & $204 / 238(85 \%)$ \\
\hline PST7:7 e 8 & AAQ02904 & $\begin{array}{l}\text { serine protease CL5 } \\
\text { precursor }\end{array}$ & Trimeresurus stejnegeri & 389 & $183 / 235(77 \%)$ & $195 / 235(82 \%)$ \\
\hline
\end{tabular}


Tabela 25: Concentração do RNA total isolado das amostras dos clones de célula CHO-DXB11 x pED-Giro na presença ou ausência de MTX para RTPCR e da célula controle negativo CHO-DXB11 dhfr.

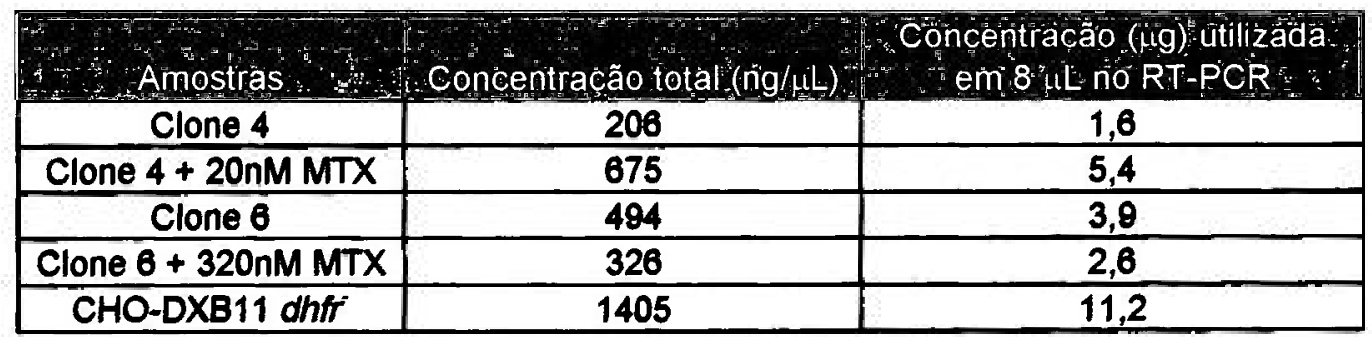


sela 26. Quantificação de proteína e atividade específica da proteína recombinante antes e após a purificação por resina afinidade benzamidina-sepharose.

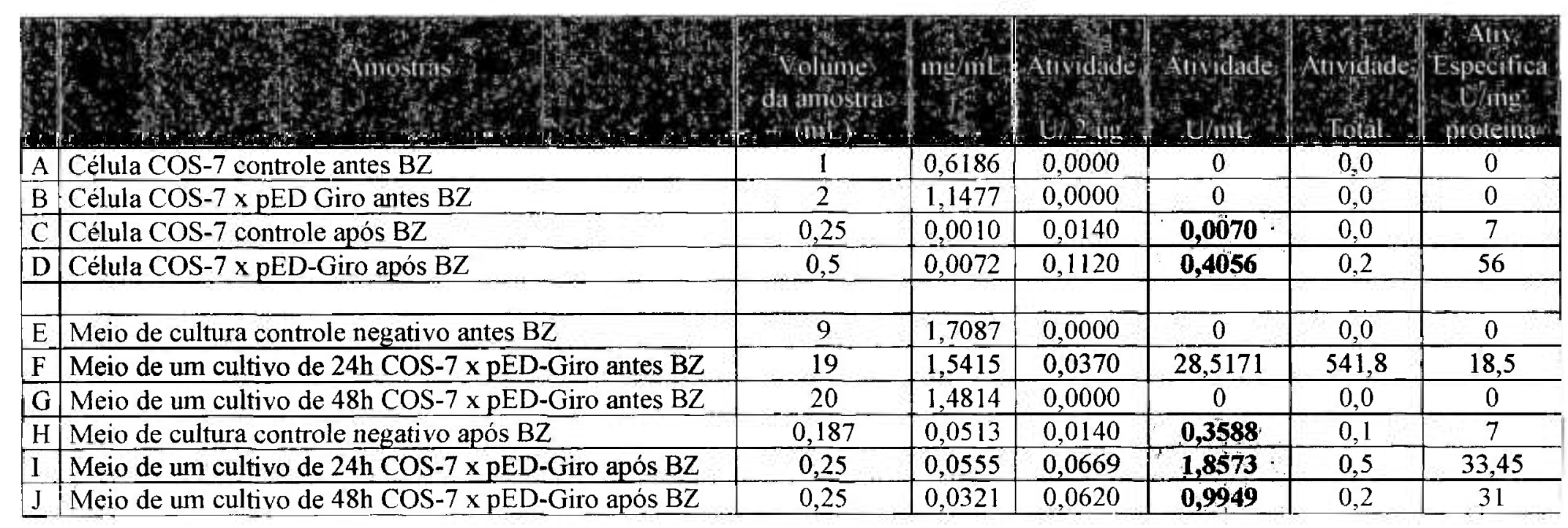




\section{APENDICES}

\subsection{Protocolos de Biologia Molecular}

\subsection{1- Eletroforese em gel de agarose.}

Os géis de agarose a $1 \%$ e/ou $1,5 \%$, de acordo com o tamanho dos fragmentos de DNA são realizados, aquecendo-se a agarose em $1 \mathrm{X}$ tampão TAE (Tris/Acetato/EDTA:40mM de Tris Base, $20 \mathrm{mM}$ de ácido acético glacial e $1 \mathrm{mM}$ de EDTA pH 8,0) sob completa dissolução. Após a agarose polimerizar, realiza-se a eletroforese juntamente com o marcador de DNA, em tampão TAE com brometo de etídio $(0,5 \mu \mathrm{g} / \mathrm{mL})$ a $50 \mathrm{~V}$. O gel é visualizado no Image Master VDS.

\subsection{2-Reação de ligação}

\subsubsection{1-Topoisomerase ( $P C R 2.1 T O P O)$.}

As reações de ligação foram realizadas incubando-se 30 minutos a temperatura ambiente, o produto de PCR (inserto) contendo terminações $5^{\prime}$ desoxiadenosina com 0 vetor PCR2.1TOPO com terminações $3^{\prime}$-timidina conjugada à enzima topoisomerase I. A proporção molar utilizada é 3:1 (inserto: vetor), em uma solução de concentração final de $200 \mathrm{mM} \mathrm{NaCl}$ e 10 $\mathrm{mM} \mathrm{MgCl} 2$ para transformar bactérias quimicamente competentes. No caso de serem usadas bactérias eletrocompetentes a ligação é realizada em uma solução de baixa concentração salina (50 mM NaCl, 2,5 mM MgCl 2 ).

\subsubsection{2- T4 DNA ligase.}

A reação de ligação é realizada utilizando-se a enzima T4 DNA ligase e $1 \mathrm{mM}$ de ATP em um tampão de acordo com as especificações do fabricante e o DNA na proporção picomolar de 3:1 e/ou 1:1 (inserto/vetor). Como controle da reação, utiliza-se $1 \mu \mathrm{L}$ do vetor não recombinante nas mesmas condições, com exceção do inserto.

A reação é incubada a $4^{\circ} \mathrm{C}$ por 16 horas. Após esse período a enzima é inativada a $65^{\circ} \mathrm{C}$ por 10 minutos. 


\subsection{3- Métodos de transformação.}

\subsubsection{1-Bactérias competentes.}

O preparo de bactérias quimicamente ultra competentes foi baseado no método de INOUE et al 1990 e o preparo de bactérias eletrocompetentes foi baseado no método descrito em SAMBROOK \& RUSSELL, 2001.

\subsubsection{2-Método de tranformação por eletroporação.}

Incubam-se $2 \mu \mathrm{L}$ de ligação em $80 \mu \mathrm{L}$ de bactérias eletrocompetentes e coloca-se a mistura na cubeta de eletroporação. Ao colocar a cubeta no eletroporador, aplica-se tensão com os seguintes parâmetros: voltagem de $1500 \mathrm{~V}$, resistência de $25 \Omega$ e corrente de $25 \mathrm{~mA}$ por 1 pulso de aproximadamente 1 segundo.

\subsubsection{3-Método de transformação por choque térmico.}

Adicionam-se $2 \mu \mathrm{L}$ do produto de ligação em $80 \mu \mathrm{l}$ de bactérias quimicamente competentes e mistura-se gentilmente. Incuba-se no gelo por 30 minutos. Dá-se um choque térmico nas células por 30 segundos a $42^{\circ} \mathrm{C}$ e transfere-se imediatamente para o gelo por 5 minutos.

\subsection{4- Isolamento de colônias transformantes}

Após a transformação por um dos métodos descritos, adicionam-se $400 \mu \mathrm{L}$ de meio $S O C$ e incuba-se a $37^{\circ} \mathrm{C}$, a $200 \mathrm{rpm}$ por 1 hora. Espalham-se $50 \mu \mathrm{L}, 100 \mu \mathrm{L}$ e $200 \mu \mathrm{L}$ de cultura bacteriana em placas seletivas de LB $^{\text {AMP }_{3}}$ ágar contendo ou não X-gal/IPTG.

\subsection{5- Reação em Cadeia da Polimerase (PCR) para clonagens.}

Uma reação de PCR com um volume final de $25 \mu \mathrm{L}$ contém: $0,2 \mu \mathrm{M}$ de cada primer específico, 1 a $5 \mathrm{U} / 100 \mu \mathrm{L}$ de Taq DNA polimerase Recombinante ou Platinum $5 U / \mu \mathrm{L}, 0,2 \mathrm{mM}$ da mistura de dNTPs (dATP, dCTP, dGTP e dTTP), $2 \mathrm{mM}$ de $\mathrm{MgCl}_{2}$, 100ng do DNA molde, não ultrapassando $10 \%$ do volume final em um tampão de acordo com as especificações do fabricante.

As reações de PCR são feitas em um termociclador térmico (Perkin Elmer 9600 ) por $94^{\circ} \mathrm{C}$ por 5 minutos, 10 ciclos de $94^{\circ} \mathrm{C}$ por 45 segundos, para denaturar o DNA molde, $52^{\circ} \mathrm{C}$ por 45 segundos para o anelamento dos 
primers, $72^{\circ} \mathrm{C}$ por 1 minuto para polimerização; 25 ciclos de $94{ }^{\circ} \mathrm{C}$ por 45 segundos, $42^{\circ} \mathrm{C}$ por 45 segundos para o anelamento dos primers, $72^{\circ} \mathrm{C}$ por 1 minuto. Ao final dos ciclos de polimerização a reação é finalizada por um ciclo de extensão a $72^{\circ} \mathrm{C}$ por 7 minutos e mantidas a $4^{\circ} \mathrm{C}$ até a análise em gel de agarose.

\subsection{6- Purificação por fenol/clorofórmio e precipitação do DNA.}

O DNA é purificado, acrescentando-se $0,5 \times$ de fenol equilibrado (tamponado em Tris $\mathrm{HCl}$ pH 8,0) e $0,5 \times$ clorofórmio. Após a centrifugação a $14.000 \mathrm{rpm}$ por 5 minutos é retirado o sobrenadante e para precipitar o DNA, acrescenta-se 0,1 $\times$ acetato de sódio $3 \mathrm{M}$ pH 5,2 e 2,5 x álcool etílico $100 \%$. Após 20 minutos no gelo, centrifuga-se a $14.000 \mathrm{rpm}$ por 5 minutos, descartase o sobrenadante e acrescentam-se $500 \mu \mathrm{L}$ de álcool etílico a $70 \%$ para realizar a lavagem do DNA precipitado, centrifuga-se novamente a $14.000 \mathrm{rpm}$ por 5 minutos e ressuspende-se em água no volume desejado.

\subsection{7- Seleção dos clones recombinantes}

\subsubsection{1- por $\alpha$-complementação.}

Quando for adequado ao tipo de vetor, colônias recombinantes (brancas) são selecionadas das colônias não recombinantes (azuis) em placas de meio seletivo $L B^{A M P} / X$-gal e IPTG ágar.

\subsubsection{2-Por tamanho do plasmídeo recombinante.}

Quando for adequado, os plasmídeos recombinantes foram identificados pelo seu tamanho aparente de migração em gel de agarose em comparação com o plasmídeo não recombinante, segundo o método descrito por BEUKEN et al, 1998.

Selecionam-se colônias isoladas de bactérias transformadas com 0 plasmídeo recombinante produto da ligação vetor e inserto. Como controle utiliza-se uma colônia bacteriana transformada com o vetor vazio não recombinante. As colônias selecionadas são cultivadas em $3 \mathrm{~mL}$ de meio líquido $\mathrm{LB}^{\mathrm{AMP}}$ à $37^{\circ} \mathrm{C}$ durante a noite em 200 rotações por minutos. 
Retiram-se $150 \mu \mathrm{L}$ do meio de cultura e centrifuga-se por 20 segundos a $14.000 \mathrm{rpm}$. O sobrenadante é transferido para um novo tubo de centrífuga e acrescentam-se $40 \mu \mathrm{L}$ da solução $0,1 \%$ de azul de bromofenol, $6 \%$ de sacarose e $14 \mu \mathrm{L}$ de uma solução de fenol equilibrado $\mathrm{pH} 8,0$ e clorofórmio $(1: 1)$.

Homogeiniza-se as amostras utilizando-se o vórtex e após lisar as células as amostras são centrifugadas por 3 minutos a $14.000 \mathrm{rpm}$. Aplica-se $10 \mu \mathrm{L}$ da fase superior (aquosa) em um gel de agarose 1,5\%, juntamente com um marcador de DNA. Em cada extremidade do gel aplica-se uma amostra controle de DNA do respectivo plasmídeo não recombinante e uma alíquota da suspensão bacteriana correspondente ao vetor vazio.

\subsubsection{3-Por PCR de colônias.}

A reação em cadeia da polimerase de colônias transformadas com 0 produto de ligação vetor-inserto são cultivadas em $3 \mathrm{~mL}$ de meio líquido $\mathrm{LB}^{\text {AMP }}$. É realizado o PCR de colônias, na qual cada reação de PCR $(15 \mu \mathrm{L})$ contém 0,2 $\mu \mathrm{M}$ dos primers específicos, (1 a $5 \mathrm{U} / 100 \mu \mathrm{L}$ ) de Taq DNA polimerase Recombinante $5 \mathrm{U} / \mu \mathrm{L}, 0,2 \mathrm{mM}$ de cada desoxinucleotídeo - dATP, dCTP,dGTP e dTTP , $2 \mathrm{mM}$ de $\mathrm{MgCl}_{2}, 1,5 \mu \mathrm{L}$ do DNA molde (suspensão da cultura bacteriana), não ultrapassando $10 \%$ do volume final em um tampão de acordo com as especificações do fabricante.

A reação é de 30 ciclos de $94^{\circ} \mathrm{C}$ por 1 minuto, $48^{\circ} \mathrm{C}$ por 1 minuto, $72^{\circ} \mathrm{C}$ por 90 segundos. Ao final dos ciclos de polimerização a reação é finalizada por um ciclo de extensão a $72^{\circ} \mathrm{C}$ por 7 minutos e mantidas a $4^{\circ} \mathrm{C}$ até a análise em gel de agarose.

\subsubsection{4-Por mapa de restrição.}

Os possiveis plasmídeos recombinantes selecionados por tamanho ou por PCR, após a extração do DNA plasmidial, podem ser confirmados após a digestão com as enzimas adequadas seguindo as instruções do fabricante, realiza-se a eletroforese em gel de agarose 1,5\%, juntamente com um marcador de DNA. O tamanho dos fragmentos resultantes da digestão dos plasmídeos recombinantes deverá estar de acordo com o mapa de restrição. 
9.1.8- Preparação de DNA plasmidial e purificação do DNA em gel de agarose.

Foram utilizados kits de Miniprep pelo método de lise alcalina e o DNA foi purificado do gel de agarose utilizando-se os protocolos dos kits.

Os plasmídeos preparados por estes métodos foram utilizados como molde para $\mathrm{PCR}$, para clonagens e subclonagens, para seqüenciamento e para transfecção em células de mamíferos.

\section{2- Meios de Cultura.}

\subsection{1-Meio líquido}

\subsubsection{1- LB (Meio Luria Bertani)}

O meio LB é composto de triptona ( $10 \mathrm{~g} / \mathrm{L}$ ), extrato de levedo $(5 \mathrm{~g} / \mathrm{L})$ e $\mathrm{NaCl}(10 \mathrm{~g} / \mathrm{L}), 0 \mathrm{pH}$ final deverá ser ajustado para $7,0 \mathrm{com} \mathrm{NaOH} 0,1 \mathrm{~N}$. O meio deve ser esterilizado por autoclave e estocado a temperatura ambiente.

\subsubsection{2-LB ${ }^{A M P}$}

Este meio de cultura seletivo é o meio LB acrescido de $50 \mu \mathrm{g} / \mathrm{mL}$ de ampicilina.

As colônias recombinantes são cultivadas nesse meio de cultura durante a noite, $37^{\circ} \mathrm{C}$ e com 200 rotações por minutos (rpm).

\subsubsection{3-SOB e SOC}

$O$ meio SOB consiste de $20 \mathrm{~g} / \mathrm{L}$ de triptona, $5 \mathrm{~g} / \mathrm{L}$ de extrato de levedo, $0,5 \mathrm{~g} / \mathrm{L}$ de $\mathrm{NaCl}$. Acrescentam-se $2,5 \mathrm{mM}$ de $\mathrm{KCl}$ e $\circ \mathrm{pH}$ é ajustado para 7,0 com $5 \mathrm{~N}$ de $\mathrm{NaOH}$. O meio é esterilizado por autoclave e antes de usar, acrescenta-se $10 \mathrm{mM}$ de $\mathrm{MgCl}_{2}$. O meio SOC é o meio SOB acrescido de 20 $\mathrm{mM}$ de glicose. 


\subsection{2-Meios sólidos.}

\subsubsection{1- LB-ágar.}

Este meio sólido é o meio $L B$ acrescido de $15 \mathrm{~g} / \mathrm{L}$ de ágar e o $\mathrm{pH}$ final deverá ser ajustado para 7,0. O meio deve ser esterilizado por autoclave. Espera-se esfriar até cerca de $50^{\circ} \mathrm{C}$ e distribui aproximadamente $30 \mathrm{~mL}$ de meio em placas de $50 \mathrm{~cm}^{2}$ em superfície plana nivelada e espera-se solidificar. Estocar a $4^{\circ} \mathrm{C}$ por até 1 mês.

\subsubsection{2-LB ${ }^{A M P}$ - Agar.}

Este meio de cultura seletivo é o LB-ágar acrescido de $50 \mu \mathrm{g} / \mathrm{mL}$ de ampicilina acrescentada antes da solidificação a uma temperatura aproximada de $46^{\circ} \mathrm{C}$.

\subsubsection{3- LB $^{A M P} / X$-gal e IPTG ágar.}

Este meio de cultura seletivo é o $\mathrm{LB}^{\mathrm{AMP}}$ acrescido de $20 \mu \mathrm{g} / \mathrm{mL}$ de X-gal (5-bromo-4-cloro-3-indol- $\beta$-D-galactosidase) e $0,1 \mathrm{mM}$ de IPTG (isopropyl- $\beta$ D-tio-galactosidase) antes da solidificação a uma temperatura aproximada de $46^{\circ} \mathrm{C}$. Com este meio realiza-se a seleção dos clones recombinantes por $\alpha$ complementação.

\subsubsection{4-Meio YT.}

Este meio de cultura é composto por triptona $8 \mathrm{~g} / \mathrm{L}$, extrato de levedura $5 \mathrm{~g} / \mathrm{L} \mathrm{e} \mathrm{NaCl} 2,5 \mathrm{~g} / \mathrm{L}$.

\section{3- Enzimas.}

$\mathrm{Na}$ tabela 4 encontram-se as enzimas de restrição, de modificação e amplificação de DNA. Os ensaios enzimáticos seguiram as condições de reação de acordo com as instruções do fabricante. Quando necessário as enzimas de restrição foram inativadas por calor a $65^{\circ} \mathrm{C}$ por 20 minutos e a enzima de modificação a $70^{\circ} \mathrm{C}$ por 10 minutos ou foram inativadas segundo o protocolo purificação por fenol/clorofórmio seguido da precipitação do DNA. 


\section{4-Vetores.}

\subsection{1- Vetor PCR2.1 TOPO.}

O vetor PCR2.1 TOPO promove uma elevada eficiência de recombinação, sendo um passo de estratégia de clonagem. A partir do produto de PCR amplificado pela TaqDNA polimerase realiza-se uma inserção direta do amplicom nesse vetor, não sendo necessária utilizar a enzima T4 DNA ligase.

Esse vetor é fornecido linearizado com extremidades coesivas contendo uma timidina ( $T$ ) a 3 'e a topoisomerase é covalentemente ligado ao vetor, tornando-o ativo. A enzima Taq polimerase é capaz de adicionar uma adenina (A) na extremidade $3^{\prime}$ do produto de PCR. A topoisomerase I do vírus Vaccinia cliva a cadeia fosfodiéster promovendo a ligação do inserto ao vetor.

Esse vetor apresenta o gene completo do LacZa no sítio de clonagem, gene para resistência aos antibióticos ampicilina e kanamicina. O gene lacz codifica para a enzima $\beta$ - galactosidase. Essa enzima normalmente cliva dissacarídeos, como lactose em monossacarideos, mas pode clivar o substrato cromogênico artificial 5-bromo-4-cloro-3-indol- $\beta$-D-galactosidase ( $X$-gal), sendo possivel rastrear a produção da $\beta$-galactosidade nas bactérias em placas contendo $X$-gal e o indutor do gene lacZ -IPTG (isopropyl- $\beta$-D-tiogalactosidase). Em uma placa contendo $X$-gal, IPTG e ampicilna, as colônias que crescerem apresentam resistência a ampicilina devido a presença do plasmídeo. Colônias que contém o plasmideo sem o inserto (produto do PCR) serão $\operatorname{lac}^{+}$e azuis, já as colônias que contém o plasmídeo com o inserto rompendo o gene lacZ serão lacZ e brancas. A vantagem de se utilizar esse vetor é que devido à ação da topoisomerase I, a quantidade de recombinantes sem inserto é muito reduzida.

\subsection{2- Vetor pSecTag2HygroA.}

o vetor pSecTag2HygroA é um vetor de expressão e secreção da proteína recombinante em célula de mamífero. A proteína expressa é fusionada com o peptídeo sinal Ig kappa murina promovendo a secreção da proteína e apresenta um peptídeo no C-terminal com o epítopo de $c$-myc e seis resíduos de histidina in tandem para deteç̧ão e purificação. 
Esse vetor apresenta algumas características: o promotor de citomegalovírus humano (CMV) permite uma alta eficiência e elevada expressão da proteína recombinante, o promotor T7/priming site permite a transcrição in vitro no sentido sense $\left(5^{\prime} \rightarrow 3^{\prime}\right)$ formando ssDNA que permite seqüenciar o inserto clonado, o códon de início ATG permite o início da tradução da proteína fusionada com o peptídeo sinal Ig kappa murina, o peptídeo sinal Ig kappa murina permite a secreção da proteína fusionada, o sítio de múltipla clonagem permitirá a inserção do gene de interesse, a proteína $c-m y c$ permite a detecção da proteína fusionada com o anticorpo anti-myc, a cauda de polihistidina facilita a purificação pois as histidinas apresentam alta afinidade pela resina quelante de $\mathrm{Ni}^{2+}$, o pcDNA3.1/BGH reverse priming site permite sequenciar através do inserto, o sinal de poliadenilação do hormônio de crescimento bovino (BGH) é uma terminação eficiente da transcrição e poliadenilação do mRNA, origem f1 permite resgatar DNA de fita simples, a origem e o promotor de SV40 permite uma eficiente e elevada expressão do gene da resistência para higromicina e replicação epissomal em células que expressam o antígeno T SV40, o gene para resistência a higromicina seleciona os clones estáveis em uma transfeç̧ão permanente em célula de mamífero, o sinal de poliadenilação SV-40, permite uma terminação da transcrição eficientemente e poliadenilação do RNAm, origem pUC permite uma replicação com um elevado número de cópias em E.coli e o gene para resistência a ampicilina ( $\beta$-lactamase) permite a seleção em E.coli.

\subsection{3- Vetor pED.}

O plasmídeo PED é um vetor na qual o gene do produto de interesse é clonado em fusão com o gene do dhfr (diidrofolato redutase), sendo um vetor eficiente para expressão transiente em células de mamíferos e sendo principalmente usado para transfecção estável, na qual o plasmídeo se integra no cromossomo da célula hospedeira. Este vetor apresenta um sítio interno de ligação aos ribossomos (IRES) isolado do vírus da encefalomiocardite (EMC) entre o gene de interesse e a fusão com o gene de dhfr. A presença do fragmento EMC em construções dicistrônicas possibilita obter altos 
rendimentos proteicos que se mantém estáveis mesmo na ausência dos respectivos agentes de seleção/amplificação. Os vetores construídos com essa modificação estão menos sujeitos a deleções ou rearranjos de DNA sendo úteis para obter altos níveis de expressão de genes heterólogos em células eucariotas

Este vetor apresenta origem de replicação do vírus SV40 e o elemento ativador da transcrição (SV40); promotor derivado do adenovírus (AdMLP); sequência "leader" derivada do adenovírus (AdTLP); um intron híbrido composto pela sequência 5 'leader não traduzida derivada do adenovírus e uma sequência $3^{\prime}$ do gene da imunoglobulina (IVS);região $5^{\prime}$ "leader" não traduzida do vírus da encelamomiocardite (ECM-L); região que codifica da enzima diidrofolato redutase murina (DHFR); região de poliadenilação do SV40 (SV40pa). (KAUFMAN, 2000).

A origem de replicação do vírus simian SV 40 promove uma grande quantidade de cópias nas células COS-1 e utiliza o promotor do adenovírus para iniciar a transcrição. A expressão do mRNA dicistrônico deste vetor pode ser utilizado para selecionar a expressão do DHFR em células deficientes em dhfr, como a célula CHO-DXB11 dhfr. O dhfr é uma marca de seleção amplamente utilizada; cataliza a conversão do folato para o tetrafolato (FH4). O FH4 é necessário para a biossíntese da glicina a partir de serina, para a biosíntese de timidina monofosfatada e para síntese de purinas. O MTX (metotrexato) é um análago do ácido fólico, na qual se liga e inibe a ação da DHFR levando a célula a morte. Quando as células são seleciondas e aumentase a concentração de MTX, a população que sobrevive contém elevados níveis de DHFR que resulta da amplificação do gene $d h f r$, conseguindo dessa forma um elevado nível de expressão (5 a $20 \mu \mathrm{g} / \mathrm{ml}$ ) (KAUFMAN, 1990, KAUFMAN 2000).

\section{5- Seqüenciamento.}

Os plasmídeos recombinantes foram amplificados em bactérias competentes E.coli TOP 10 ou DH5 $\alpha-T 1 R$ e purificados com o kit de Miniprep pelo método de lise alcalina S.N.A.P $P^{T M}$ Miniprep kit (Invitrogen). Após 
quantificar o DNA no espectrofotômetro em uma absorbância 260 nm, o DNA foi diluído para uma concentração de $100 \mathrm{ng} / \mu \mathrm{L}$.

Para realizar o sequenciamento no Centro de Estudo do Genoma Humano $\left({ }^{1}\right)$ os plasmídeos que apresentam um tamanho de até $4 \mathrm{~kb}$ serão utilizados $200 \mathrm{ng} / \mu \mathrm{L}$ de DNA. Para plasmideos que apresentam um tamanho de 5 e $6 \mathrm{~kb}$ serão utilizados respectivamente 250 e $300 \mathrm{ng} / \mu \mathrm{l}$ de DNA. São utilizadas as seguintes quantidades de reagentes por reação: $4 \mu \mathrm{L}$ do reagente DyEnamic ET Terminator premix, $1 \mu \mathrm{L}$ do primer ( $5 \mathrm{pmol} / \mu \mathrm{L}$ ), e uma quantidade do plasmídeo equivalente a $200 \mathrm{ng} / \mu \mathrm{L}$ até $300 \mathrm{ng} / \mu \mathrm{l}$ de acordo com o seu tamanho, água deionizada MilliQ (18M $\Omega$ ) para o volume final de 10 $\mu \mathrm{L}$.

As condições de termociclagem são: 30 ciclos de desnaturação à $95^{\circ} \mathrm{C}$ por 20 segundos; anelamento dos primers na temperatura $\left({ }^{\circ} \mathrm{C}\right)$ de acordo com o seu Tm por 15 segundos e a polimerização a $60^{\circ} \mathrm{C}$ por 1 minuto e 15 segundos.

Após reação o DNA foi precipitado com o seguinte protoloco: adicionando-se $1 \mu \mathrm{L}$ de Acetato de Amônio 7,5M e $28 \mu \mathrm{L}$ de Etanol $100 \%$ a cada reação. Agitar os tubos para homogeneizar. A concentração final do Etanol deve ser $70 \%$. Manter os tubos à temperatura ambiente por 15 minutos (em ambiente escuro). Centrifugar os tubos à temperatura ambiente em microcentrifuga por 15 minutos em rotação máxima (aproximadamente $13.000 \mathrm{rpm}$ ). Remover o sobrenadante por aspiração (utilize micropipeta). Adicionar $170 \mu \mathrm{L}$ de Etanol $70 \%$ para lavar o pellet. Centrifuguar nas mesmas condições descritas anteriormente. Remover o sobrenadante por aspiração e deixe o pellet secar ao ar (em ambiente escuro). Ressuspender o pellet em 20 $\mu \mathrm{L}$ de Loading Solution. Homogeneizar o tubo e manter a $4^{\circ} \mathrm{C}$ protegido da luz. O seqüenciamento é realizado em sequenciador automático MegaBACE 1000, um sistema de análise de DNA de 96 capilares com a tecnologia GE Healthcare de acordo com o protocolo para MegaBACE 1000 utilizando o DYEnamic ET Dye Terminator kit com Thermo Sequenase ${ }^{\mathrm{TM}}$ II DNA Polimerase) código US81090. As sequências são analisadas pelo software Sequence Analyser utilizando o Base Caller Cimarron 3.12.

\footnotetext{
${ }^{1}$ http://genoma.ib.usp.br/servicos/sequenciamento.php
} 


\section{6- Análise de proteína.}

\subsection{1 - Eletroforese em gel de poliacrilamida com SDS.}

A análise em eletroforese em gel de poliacrilamida (SDS-PAGE) foi baseada em LAEMMLI, 1970. As amostras foram dissolvidas em 1x tampão de amostra SDS-PAGE contendo $1 \% \beta M E$ ( $\beta$ mercaptoetanol) e fervidas por 10 minutos, imediatamente antes da aplicação no gel. Para tanto, foi utilizado gel a $15 \%$, medindo $5,5 \times 8,5 \mathrm{~cm}$, corrente constante a $90 \mathrm{~V}$ e temperatura ambiente. A fixação e coloração foi feita segundo a técnica com Coomassie Blue R 250 a $0,25 \%$ dissolvido em metanol 50\%/ácido acético $10 \%$. Para a análise em Western blot não foi feita a fixação ou coloração, pois logo após a corrida da eletroforese as amostras começaram a ser transferidas para a membrana de nitrocelulose.

\subsection{2- Western Blots.}

Os Western blots usaram o soro eqüino anti-crotálico do Instituto Butantan. De maneira geral, os protocolos de western blot seguiram o protocolo descrito por AUSUBEL et al, 1989. Os SDS-PAGEs contendo os extratos celulares e os meios de cultura foram eletrotransferidos em sistema semi-seco para uma membrana de nitrocelulose. O tampão de transferência utilizado foi Tris- $\mathrm{HCl} 0,94 \mathrm{~mol} / \mathrm{L} \mathrm{pH} \mathrm{8,8;} \mathrm{glicina} \mathrm{0,33mol/L;} \mathrm{SDS} \mathrm{1,5 \%} \mathrm{contendo}$ $10 \%$ de metanol. A transferência foi feita com uma corrente de $0,8 \mathrm{~mA} / \mathrm{cm}^{2}$ de gel por 45 minutos. A membrana foi corada com Poceau S 5\%, ácido acético $1 \%$ por 5 minutos, lavada com água destilada e as posições das canaletas foram marcadas. O padrão de peso molecular utilizado foi o Low-Range Rainbow Molecular Weight Marker. O bloqueio foi realizado com TTBS (100mM Tris- $\mathrm{HCl} \mathrm{pH} 7,5 ; 0,9 \% \mathrm{NaCl} ; 0,1 \%$ de Tween-20) e $10 \%$ de leite em pó desnatado MOLICO por 1 hora.

Como anticorpo primário foi utilizado o soro equinos anti-crotálico (Instituo Butantan) incubando as membranas de nitrocelulose durante a noite numa diluição de 1:1000 em TTBS No dia seguinte, foram realizadas 4 lavagens de $50 \mathrm{ml}$ com TTBS de 10 minutos cada. O anticorpo secundário utilizado foi anti-IgG biotinilada eqüina feito em coelho (Sigma) diluído 1:2000 
em TTBS. A membrana foi incubada $2 \mathrm{~h}$ com esse anticorpo. Repetiram-se as lavagens TTBS e por fim a membrana foi lavada com 50ml TBS (TTBS na ausência do Tween 20) por 15 minutos. Para revelar a membrana foi utilizado peroxidase e luminol segundo as especificações do fabricante (kit ECL + PLUSWestern blotting detection system). 


\section{0-REFERÊNCIAS BIBLIOGRÁFICAŚS}

ALVES DA SILVA, J.A, MURAMOTO, E, RIBELA,M.T.C.P, ROGERO,J.R, CAMILLO, M.A.P. Biodistribution of gyroxin using $125 \mathrm{I}$ as radiotracer. Journal of Radioanalytical and Nuclear Chemistry, v.269, n.3, p. 579-583, 2006.

ALEXANDER, G., GROTHUSEN, J., ZEPEDA, H. \& SCHWARTZMAN, R.J. Gyroxin, a toxin from the venom of Crotalus durissus terrificus is a thrombin-like enzyme. Toxicon, v. 26, n.10, p. 953-960, 1988.

AMARAL, A. In.Serpentes do Brasil: iconografia colorida. Editora da Universidade de São Paulo. São Paulo, 1978.

AMICONI, G., AMORESANO, A., BOUMIS, G., BRANCACCIO, A., DE CRISTOFARO, R., DE PASCALIS, A., DI GIROLAMO, S., MARAS, B., SCALONI, A. A Novel Venombin B from Agkistrodon contortrix contortrix: Evidence for recognition properties in the surface around the primary specificty pocket different from Thrombin. Biochemistry., v. 39, p. 10294-10308, 2000.

AROCAS, V, CASTRO,H.C,ZINGALI R.B,GUILLIN, M.C, JANDROT-PERRUS, M, BON,C, WISNER,A. Molecular cloning and expression of bothrojaracin, a potent thrombin inhibitor from snake venom. Eur. J. Biochem., v.248, n.2, p. 550-557, 1997.

ARRUDA PAES, P.C, CAMILLO, M.A P.,ROGERO,J.R. Estudo da ação das toxinas semelhantes à trombina dos venenos de cascavel e surucucu sobre fibrinogênio e plaquetas. ANAIS DO VI ENCONTRO ANUAL DE INICIAÇÃo CIENTÍfICA, Ponta Grossa, PR, 1996.

AUSUBEL,F.M.,BRENT,R., KINGSTON,R.E.,MOORE,D.D.,SEIDMAN,J. D.SMITH,J.A.,STRUHL,K. Current Protocols in Molecular Biology, v.1, suppl.24 .John Willey \& Sons N.Y, 1989.

BARRABIN, H., MARTIARENA, J.L., VIDAL, J.C., BARRIO, A. Isolation and characterization of gyroxin from Crotalus durissus terrificus venom. In: ROSEMBERG, P. Toxins: Animals, Plant and Microbial. New York, USA, Pergamon Press, p. 113-133, 1978.

BARRIO, A. Gyroxin, a new neurotoxin of Crotalus durissus terrificus venom. Acta Physiol. Latinoamer., v.11, p. 224, 1961 
BERCOVICI,D.,CHUDZINISKI,A.M.,DIAS, W.O,STEVES,M.I.,HIRAICHI, E., OISHI,N.Y., PICARELLI,Z.P., ROCHA,M.C., UEDA,C.M.P.M., YAMANOUYE,N., RAW,I. A systematic fractionation of Crotalus durissus terrificus venom. Mem.Inst.Butantan, v.49,n.3,p.69-78,1987.

BEUKEN,E.,VINK,C.,BRUGGEMAN,C.A. One step procedure for screening recombinant plasmids by size. BioTechniques,v.24, p.748-750, 1998.

BJARNASON J.B., BARISH A., DIRENZO G.S., CAMPBELL R., FOX J.W. Kallikrein-like enzymes from Crotalus atrox venom. J. Biol. Chem. v. 258, p.12566-12573, 1983.

BRADFORD, M.M. A rapid and sensitive method for the quantitation of microgram quantities of protein utilizing the principle of Protein-Dyue binding - Analytical Biochemistry. v. 72, p. 248-254. 1976.

BRATTSTROM, B.H. Evolution of the pit vipers. Transactions of the San Diego Society of Natural History, v. 13, n011, p. 185-268, 1964.

BURKHART W., SIMTH G.F.H., SU J.-L., PARIKH I., LEVINE H. I.I.I. Amino acid sequence determination of ancrod, the thrombin-like alphafibrinogenase from the venom of Akistrodon rhodostoma. FEBS Lett. v. 297, p.297-301, 1992.

CAMILLO, M.A.P. Contribuição ao estudo das giroxinas (enzimas semelhantes à trombina) dos venenos das serpentes brasileiras Lachesis muta muta e Crotalus durissus terrificus.1998 Tese (Doutorado)- Instituto de Pesquisas Energéticas Nucleares, São Paulo.

CAMILLO,M.AP., ARRUDA PAES,P.C., TRONCONE, L.R.P.,ROGERO,J.R. Gyroxin fails to modify in vitro release of labelled dopamine and acetylcholine from rat and mouse striatal tissue. Toxicon,v.39,p.843853, 2001.

CAMILLO, M.A.P, ALVES DA SILVA, J.A., YONAMINE, C.M, HASHIZUME, J. L, CASARE, M.S, HIGA, O. Z. Biological activity and structural alterations in gyroxin induced by gamma radiation. In: International Nuclear Atlantic Conference Proceedings of VII ENAN. Brazilian Association for Nuclear Energy- ABEN, Santos-SP, p. 1845-1850, 2005.

CASTRO, H.C., ZINGALI, R.B., ALBUQUERQUE, M.G., PUJOL-LUZ, M., RODRIGUES, C.R. Snake venom thrombin-like enzymes: from reptilase to now. Cell. Mol. Life. Sci, v. 61, p. 843-856, 2004. 
CHARBONNIER, F., GASPERA,B.D., ARMAND, A.S., VAN DER LAARSE, W.J, LAUNAY,T.,BECKER,C., GALLIEN, C.L., CHANOINE, C. Two myogeninrelated genes are differentially expressed in Xenopus laevis myogenesis and differ in their ability to transactivate muscle structural genes. The Journal of Biological Chemistry., v. 277, n. 2, p. 1139-1147, 2002.

CHURA-CHAMBI,R.M., TORNIERI,P.H., SPENCER,P.J., NASCIMENTO,P.A, MATHOR,M.B., MORGANTI,L. High-level synthesis of recombinant murine endostatin in Chinese hamster ovary cells. Protein Expression and Purification, v.35, p.11-16, 2004.

DA SILVA,N.J., AIRD,S.D. SEEBART,C., KAISER,I.I. A gyroxin analog from the venom of the bushmaster (Lachesis muta muta). Toxicon., v.27, n.7, p.763-771, 1989.

DESHIMARU,M.,OGAWA,T.,NAKASHIMA,K.I.,NOBUHISA,I.,CHIJIWA, T.; SHIMOHIGASHI, Y., FUKUMAKI,Y.,NIWA, M., YAMASHINA,I., HATTORISO HNO,M. Accelerated evolution of crotalinae snake venom gland serine proteases. FEBS Letters., v.397, p.83-88, 1996.

DOSSIN, F.M \& SCHENKAN, S. Actively transcribing RNA polymerase II concentrates on spliced leader genes in the nucleus of Trypanosoma cruzi. Eukaryot Cell. v.4, n.5, p.960-70, 2005.

EWING B, Hillier $L$, WENDL M, GREEN P: Basecalling of automated sequencer traces using phred. I. Accuracy assessment. Genome Research., v. 8, P.175-185, 1998.

FAN C., QIAN Y., GONG Y., YANG S. Cloning, sequence analysis and expression in E. coli of the CDNA of thrombin like enzyme (pallabin) from Agkistrodon halys pallas. Biochem. Mol. Biol. v.47, p.217-225, 1999.

FILIPPOVICH, I, SOROKINA, N, ST PIERRE,L, FLIGHT, S, De JERSEY, J, PERRY, N, MASCI,P.P, LAVIN,M.F. Cloning and functional expression of venom prothrombin activator protease from Pseudonaja textiles with whole blood procoagulant activity. Br. J. Haematol, v.131, n.2, p. 237246, 2005.

FELSENSTEIN, J. PHYLIP - Phylogeny Inference Package (Version 3.2). Cladistics., v. 5, p.164-166, 1989.

GARCÍA, L.T., PARREIRAS E SILVA, L.T; RAMOS, O.H.P; CARMONA, A.K, BERSANETTI,P.A; SELISTRE-DE -ARAÚJO,H.S. The effect of post translational modifications on the hemorrhagic activity of snake venom metalloproteinases. Comparative Biochemistry and Physiology, Part C, v.138, p.23-32, 2004.

GRAHAM, F.L \& VAN DER EB,A.G. Transformation of rat cells by DNA of human adenovirus 5. Virology, v. 54, p. 536-539, 1973. 
GONÇALVES,J.M., VIEIRA,L.G. Estudos sobre veneno de serpentes brasileiras I. Análise eletroforética. Annais.Acad.Bras.Cienc.,v.22, n.1,p.141-149, 1950.

GOOCHEE, C.F., GRAMER, M.J, ANDERSEN, D.C.,BAHR, J.B, RASMUSSEN,J.R. Review: The oligosaccharides of glycoproteins: bioprocess factors affecting oligosaccharide structure and their effect on glycoprotein properties. Biotechnology., v.9, p.1347-1355, 1991.

GUEX, N \& PEITSCH, M.C. Swiss Model and Swiss-Pdb Viewer: An environment for comparative modeling. Electrophoresis., v. 18, n.15, p. 2714-2723, 1997.

GUO, Y.W, CHANG, T.Y, LIN, K. T, LIU, H.W, SHIH, K. C, CHENG, S.H. Cloning and functional expression of the mucrosobin protein, a betafibrinogenase of Trimeresurus mucrosquamatus (Taiwan Habu). Protein Expr. Purif, v. 23, n. 3, p. 483-490, 2001.

GUTBERLET JR, R. L. \& CAMPBELL, J. A.: Generic recognition for a neglected lineage of South American pitvipers (Squamata: Viperidae: Crotalinae), with the description of a new species from the Colombian Chacó.-American Museum Novitates. v.3316, p.1$15,2001$.

HAHN, B.S, YANG, K.Y, PARK, E.M, CHANG, I.M, KIM, Y.S. Purification and molecular cloning of calobin, a thrombin-like enzyme from Agkistrodon caliginosus (Korean viper). J. Biochem (Tokyo) v.119, n. 5, p. 835-843, 1996.

HAHN B.-S., BAEK K., KIM W.-S., LEE C.-S., CHANG I.-L., KIM Y.-S.. Molecular cloning of capillary permeability-increasing enzyme-2 from Agkistrodon caliginosus (Korean viper).Toxicon v.36,p. 887-1893, 1998.

HASHIZUME, J.L, CAMILLO, M. A. P. Ação da giroxina em células endoteliais em cultura. In: 13 Simpósio Internacional de Iniciação Científica da USP. Resumos do 13 SIICUSP-Ribeirão Preto/SP. v. 1. p. 38063806, 2005.

HENSCHEN-EDMAN, A.H., THEODOR, I., EDWARDS, B.F., PIRKLE, $H$. Crotalase, a fibrinogen-clotting snake venom enzyme: primary structure and evidence for a fibrinogen recognition exosite different from thrombin. Thromb. Haemost., v. 81, n. 1, p. 81-86, 1999.

HUANG, Q., LIU, S., TANG, Y. Refined 1.6-A resolution crystal structure of the complex formed between porcine beta-trypsin and MCTI-A, a trypsin inhibitor of the squash family. Detailed comparison with bovine betatrypsin and its complex. J. Mol. Biol. v. 229, p.1022-1030, 1993. 
HUNG,C.C \& CHIOU,S.H. Expression of a kallikrein-like protease from the snake venom: engineering of autocatalytic site in the fusion protein to facilitate protein refolding. Biochem.Biophys.Res.Comm., v.275, p.924930,2000 .

HUNG C.-C., HUANG K.F., CHIOU S.-H. Characterization of one novel venom protease with beta-fibrinogenase activity from the Taiwan habu (Trimeresurus mucrosquamatus):purification and CDNA sequence analysis.Biochem. Biophys. Res. Commun. v.205, p.1707-1715, 1994.

INOUE, H.,NOJIMA, H.,OKAYAMA,H. High efficiency transformation of Escherichia coli with plasmids. Gene. v.96, p.23-28, 1990.

ITOH, N., TANAKA, N., FUNAKOSHI, I., KAWASAKI, T., MIHASHI, S., YAMASHINA, I. The complete nucleotide sequence of the gene for batroxobin, a thrombin-like snake venom enzyme. Nucleic Acids Res.,v 16, n. 21, p. $10377-10378,1988$.

ITOH,N., TANAKA,N., MIHASHI,S., YAMASHINA,I. Molecular cloning and sequence analysis of cDNA for batroxobin, a thrombin-like snake venom enzyme J. Biol. Chem., v. 262,n. 7, p. 3132-3135, 1987.

KAUFMAN,R.J. Strategies for obtaining high level expression in mammalian cells. Technique- A Journal of Methods in Cell and Molecular Biology., v.2, n.5, p.221-236, 1990.

KAUFMAN, R.J. Gene amplification in mammalian cells. Marcel Dekker, Inc. 1992. cap.25- Amplification and Expression of Transfected Genes in Mammalian Cells, p. 315-342.

KAUFMAN,R.J. Overview of vector design for mammalian gene expression. Molecular Biotechnology., v.16, p.151-160, 2000.

KAWASAKI, E.S. PCR Protocols: A guide to methods and applications. Academic Press, Inc.1990. cap.18- Sample preparation from blood, cells and other fluids.p.146-152.

KINI, R.M. Anticoagulant proteins from snake venoms: structure, function and mechanism. Biochem. J., v.397, p.377-387, 2006.

KIMICHI-SARFATY,C., MI OH.J., KIM, I-W., SAUNA, Z.E, CALCAGNO, A.M, AMBUDKAR, S.V., GOTTESMA, M.M. A "silent" polymorphism in the MDR1 gene changes substrat specificity. Science Express, December $21,2006$.

KOH, D.C.I. ARMUGAN, A; JEYASEELAN, K. Snake venom components and their applications in biomedicine. Cell. Mol. Life. Sci, v.63, p.3030-3041, 2006. 
KOMORI Y, NIKAI T, OHARA A, YAGIHASHI S, SUGIHARA H. Effect of bilineobin, a thrombin-like proteinase from the venom of common cantil (Agkistrodon bilineatus). Toxicon, v.31, n.3, p.257-270, 1993.

KREM, M.M \& ROSE,T.,DI CERA, E. The C- terminal sequence encodes function in serine proteases. The Journal of Biological Chemistry., v.274, n.40, p.28063-28066, 1999.

KRUSE,H., GREIDANUS,V.W.Tj.B. \& DE WIED, D. Barrel rotation induced by vasopressin and related peptides in rats. Pharmacol. Biochem. Behav., v.7, p.311-313, 1977.

KUNKEL, T. A. Rapid and efficient site-specific mutagenesis without phenotypic selection. Proc.NatI.Acad.Sci. USA.,v.82, p. 488-492,1985.

LAEMMLI, U.K. Cleavage of structural proteins during the assembly of the head of bacteriophage T4. Nature (London), v.227, p.680-685, 1970.

LEWIN,B. Genes V. USA, Oxford University Press and Cell Press, 1994.

LOCHNIT,G \& GEYER,R. Carbohydrate structure analysis of batroxobin, a thrombin-like serine protease from Bothrops moojeni venom. Eur. J.Biochem, v.228, p.805-816, 1995.

MAEDA, M., SATOH, S., SUZUKI,S., NIWA, M., ITOH, N., YAMASHINA, I. Expression of cDNA for batroxobin, a thrombin-like enzyme. $J$. Biochem.,v. 109, p.632-637, 1991.

MAGALHAES A., CAMPOS-BRASIL DA FONSECA B., RIBEIRO DINIZ C., GILROY J., RICHARSON M. The complete amino acid sequence of a thrombin-like enzyme/gyroxin analogue from venom of the bushmaster snake (Lachesis muta muta).FEBS Lett. v. 329, p.116-120, 1993.

MARKLAND,F.S. Fibrin(ogen)ollytic enzymes from snake venoms. In: PIRKLE,H. \& MARKLAND Jr.,F.S. Hemostasis and animal venoms. New York, USA, Marcel Dekker Inc.,p.149-172, 1988.

MARKLAND, F.S. Review: Snake venom and the hemostatic system. Toxicon, v. 36, n. 12,p. 1749-1800. 1998.

MARSH, N.A. Use of snake venom fractions in the coagulation laboratory. Blood Coagulation and Fibrinolysis., v. 9, p. 395-404, 1998.

MASSOVA, I., PIRKLE, H., EDWARDS, B.F.P., MOBASHERY, S. Insights into the three-dimensional structure of crotalase: implications for biological activity and substrate specificity. Bioorganic \& Medicinal Chem. Lett., v. 7, n. 24, p. 3144, 1997. 
MATSUI, T., FUJIMURA, Y., TITANI, K. Snake venom proteases affecting hemostasis and thrombosis. Biochemical et Biophysica Acta. v. 1477, p. 146-156. 2000.

MATSUI,T., SAKURAI,Y., FUJIMURA,Y., HAYASHI,I. OH-ISHI,S., SUZUKI,M., HAMAKO,J., YAMAMOTO,Y., YAMAZAKI,J., KINOSHITA,M., TITANI,K. Purification and amino acid sequence of halystase from snake venom of Agkistrodon halys blomhoffii, a serine protease that cleaves specifically fibrinogen and kininogen. Eur.J.Biochem., v.252, p.569-575, 1998.

MATTISON,C. The Encyclopedia of Snakes. Facts On File, Inc. New York, 1995.

MCMULLEN B.A., FUJIKAWA K., KISIEL W. Primary structure of a protein C activator from Agkistrodon contortrix contortrix venom. Biochemistry $v$. 28, p.674-679, 1989.

MEMARI,N, GRASS,L, NAKAMURA,T, KARAKUCUK,I, DIAMANDIS,E.P. Human tissue kallikrein 9: production of recombinant proteins and specific antibodies. Biol. Chem. V.387, p.733-740, 2006.

MOREIRA, V.M.T.S. Efeitos da injeção intrahipocampal de crotoxina, crotamina e giroxina em ratos. 1993. Tese (Doutorado), Escola Paulista de Medicina, Universidade Federal de São Paulo, São Paulo.

MURAYAMA, N., SAGUCHI, K.I., MENTELE, R., ASSAKURA, M. T., OHI, H., FUJITA, Y., CAMARGO, A.C.M., HIGUCHI, S., SERRANO, S.M.T. The unsusual high molecular mass of Bothrops protease $A$, a trypsin-like serine peptidase from the venom of Bothrops jararaca, is due to its high carbohydrate content. Biochimica et Biophysica Acta, v. 1652, p. 1-6, 2003.

NIKAI T. OHARA A., KOMORI Y., FOX J.W., SUGIHARA H. Primary structure of a coagulant enzyme, bilineobin, from Agkistrodon bilineatus venom. Arch. Biochem. Biophys, v. 318, p.89-96, 1995.

NISHIDA S., FUJIMURA Y., MIURA S., OZAKI Y., USAMI Y., SUZUKI M., TITANI $K_{.}$, YOSHIDA E., SUGIMOTO M., YOSHIOKA A., FUKUI $H$. Purification and characterization of bothrombin, a fibrinogen-clotting serine protease from the venom of Bothrops jararaca. Biochemistry, $v$. 33, p.1843-1849,1994.

NOLAN, C., HALL, L.S., BARLOW, G.H. Ancrod, the coagulanting enzyme of Malayan pitviper (Agkistrodon rhodostoma) venom. Methods in Enzimology, v. 45, p. 205-213. 1976. 
OYAMA, E \& TAKAHASHI $H$. Amino acid sequence of a thrombin like enzyme, elegaxobin, from the venom of Trimeresurus elegans (Sakishima-habu). Toxicon v. 40, p.959-970, 2002.

PAN, H, DU, X, YANG, G, ZHOU, Y, WU, X. CDNA cloning and expression of acutin. Biochem Biophys Res Commun, v. 255, no 2, p. 412-415, 1999.

PARK, D., KIM,H., CHUNG,K.,KIM,D.S. YUN,Y. Expression and characterization of a novel plasminogen activator from Agkistrodon Halys venom. Toxicon v.36, p.1807-1819, 1998.

PERONI,C.N., SOARES,C.R.J., GIMBO,E., MORGANTI,L., RIBELA,M.T.C.P., BARTOLINI,P. High-level expression of human thyroid-stimulating hormone in $\mathrm{CHO}$ cells by co-transfection of dicistronic expression vectors followed by a dual-marker amplification strategy. Biotechnol.Appl.

Biochem., v. 35, p.19-26, 2002.

PRADO-FRANCESCHI, J \& VITAL BRAZIL,O. Convulxin, a new toxin from the venom of South America Rattlesnake Crotalus durissus terrificus. Toxicon, v.19, p.875-887, 1981.

RÁDIS-BAPTISTA,G, OGUIURA,N, HAYASHI,M.A,CAMARGO,M.E, GREGO,K.F, OLIVEIRA,E.B, YAMANE,T. Nucleotide sequence of crotamine isoform precursors from a single South American rattlesnake (Crotalus durissus terrificus). Toxicon, v.37, n.7, p.973-984, 1999.

RUIZ DE TORRENT, R.M., BONGIOVANNI,B., LEIVA,L.C., DE DUFFARD, A.M.E., RODRÍGUEZ,J.P., DE PÉREZ,O.C.A., DUFFARD,R. Neurotoxicological effects of a thrombin-like enzyme isolated from Crotalus durissus terrificus venom (preliminary study). Toxicon, v. 50, p. 144-152, 2007.

RAW, I., ROCHA, M.C., ESTEVES, M.I., KAMIGUTI, A.S. Isolation and characterization of a thrombin-like enzyme from the venom of Crotalus durissus terrificus. Braz. J. Med. Biol. Res., v. 19, p. 333-338, 1986.

RAWLINGS,N.D \& BARRETT, A.J. Evolutionary families of peptidases. Bioche. J., v. 290, p.205-218, 1993.

RAWLINGS, N.D. \& BARRET, A.J. Families of serine peptidases. Meth. Enzymol. v.244, p. 19-61, 1994.

SAMBROOK, S \& RUSSELL, D.W. Molecular Cloning - A laboratory manual. v. 3, 3 ed. New, York: Cold Spring Harbor, 2001.

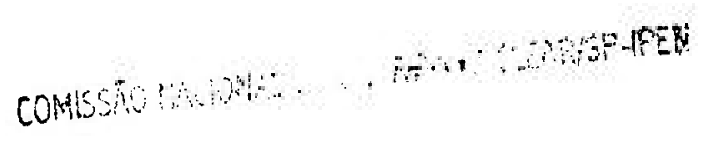


SANCHEZ E.F., SANTOS C.I., MAGALHAES A., DINIZ C.R., FIGUEIREDO S., GILROY J., RICHARDSON M. Isolation of a proteinase with plasminogenactivating activity from Lachesis muta muta (bushmaster) snake venom. Arch. Biochem. Biophys. v.378, p.131-141,2000.

SAKAI, J., ZHANG,S., CHEN,H., ATSUMI,F.,MATSUI,T., SHIONO,H., SANADA,S., OKADA,T. Primary structure of a thrombin-like serine protease, kangshuanmei, from the venom of Agkistrodon halys brevicaudus stejneger. Toxicon., v. 48, p. 313-322, 2006.

SCHULER,D.G., ALTSCHUL,S.F., LIPMAN,D.J. A Workbench for Multiple Alignment Construction and Analysis. Proteins: Strcuture, Function and Genetics. v.9, p. 180-190, 1993.

SEKI, C., VIDAL, J.C., BARRIO, A. Purification of gyroxin from a South American rattlesnake (Crotalus durissus terrificus) venom. Toxicon, v.18, p. $235-247,1980$.

SERRANO,S.M., HAGIWARA,Y., MURAYAMA,N., HIGUCHI,S., MENTELE, R., SAMPAIO, C.A , CAMARGO, A C., FINK, E. Purification and characterization of a kinin-releasing and fibrinogen-clotting serine proteinase (KN-Bj) from the venom of Bothrops jararaca and molecular cloning and sequence analysis of its CDNA. Eur.J.Biochem., v. 251, p.845-853, 1998.

SERRANO,S \& MAURON,R.C. Snake venom serine proteinases: sequence homology vs. Substrate specificity, a paradox to be solved. Toxicon, v.45,p.1115-1132, 2005.

SERRANO S.M.T., MENTELE R., SAMPAIO C.A.M., FINK E. Purification, characterization, and amino acid sequence of a serine proteinase, PA-B], with platelet-aggregating activity from the venom of Bothrops jararaca. Biochemistry, v. 34, p.7186-7193, 1995.

SHIMOKAWA, $K$ \& TAKAHASHI, $H$. Capillary permeability-increasing enzyme-2 from the venom of Agkistrodon caliginosus (kankokumamushi):activity resulting from the release of peptides from fibrinogen. Toxicon., v.35, p.597-605, 1997.

SIIGUR, E., AASPOLLU, A., SIIGUR, J. Molecular cloning and sequence analysis of a CDNA for factor $V$ activating enzyme. Biochem. Biophys. Res. Commun.v. 262, p.328-332, 1999.

SLOTTA \& FRAENKEL-CONRAT, H. Purificação e cristalização do veneno de cobra cascavel. Mems Inst. Butantan, v.12, p.505, 1938-1939. 
SOARES,C.R.J., MORGANTI,L., MILOUX,B., LUPKER,J.H., FERRARA,P., BARTOLINI,P. High-level synthesis of human prolactin in $\mathrm{CHO}$ cells. Biotechnol.Appl.Biochem.,v.32, p.127-135, 2000.

STOCKER, K., FISCHER, H., MEIER,J., BROGLI, M., SVENDSEN, L. Characterization of protein $C$ activator protac from venom of the southern copperhead (Agkistrodon contortrix) snake. Toxicon., v. 23, p. 239$252,1987$.

THOMAZINI-SANTOS, I.A , BARRAVIERA, S.R.C.S., MENDES-GIANNINI, M.J.S., BARRAVIERA, B. Surgical adhesives. J. Venom. Anim. Toxins., v.7, n.2, p.159-171,2001.

TOKUNAGA F., NAGASAWA K., TAMURA S., MIYATA T., IWANAGA S., KISIEL $W$. The factor $V$-activating enzyme (RVV-V) from Russell's viper venom. Identification of isoproteins $R V V-V$ alpha, $-V$ beta, and $-V$ gamma and their complete amino acid sequences. J. Biol. Chem. v. 263, p.17471$17481,1988$.

VITAL-BRAZIL, O. Veneno ofídico neurotóxico. Rev. Ass. Med. Brasil, 26, v.6, p.212-218, junho 1980.

VON HEIJE, G. Signal Sequences. The Limits of Variation. J.Mol. Biol, v.184, p.99-105, 1985.

WANG, Y.M., WANG, S.R., TSAI, I.H. Serine protease isoforms of Deinagkistrodon acutus venom: cloning, sequencing and phylogenetic analysis. Biochem.J.,v.354, p.161-168, 2001.

WARKENTIN, T.E. Limitations of conventional treatment options for heparin-induced thrombocytopenia. Semin. Hematol., v. 35, p.17-25, 1998.

WATSON, J.D., BAKER,T.A., BELL, S.P., GANN, A., LEVINE, M., LOSICK, R. Molecular Biology of the Gene, 5 ed, San Franscisco, CA, 2004, p. 383.

WEISEL J.W. Fibrinogen and fibrin. Adv. Protein Chem. v. 70, p. 247-299, 2005.

WILLCOX, B.J., POULIN, P., VEALE, W.L., PITTMANM Q.J. Vasopressininduced motor effects: localization of a sensitive site in the amygdala. Brain Res., v.596, n. 1-2, p. 58-64, 1992.

WURPEL,J.D., DUNDORE,R.L., BARBELLA,Y.R., BALABAN,C.D., KEIL,L.C. \& SEVERS,W.B. Barrel rotation evoked by intracerebroventricular vasopressin injections in conscious rats. I. Description and general pharmacology. Brain Res., v.365, p.21-29, 1986a. 
WURPEL,J.D., DUNDORE,R.L., BARBELLA,Y.R., BALABAN,C.D., KEIL,L.C. \& SEVERS,W.B. Barrel rotation evoked by intracerebroventricular vasopressin injections in conscious rats. II. Visual/ vestibular interactions and efficacy of antiseizure drugs. Brain Res., v.365, p. 30-41, 1986b.

YANG, Q, HU, X.J, XU, X.M, AN, L.J, YUAN, X.D, SU, Z.G. Cloning, expression and purification of gussurobin, a thrombin-like enzyme from the snake venom of Gloydius ussuriensis.Acta Biochim.Biophys.Sinica, v. 34, n.1, p.6-10, 2002.

YANG, Q, LI,M., XU,J., BAO,Y., LEI,X, NA,L. Expression of gloshedobin, a thrombin like enzyme from the venom of Gloydius shedaoensis, in Escherichia coli. Biotechn.Letters, v.25, p.101-104, 2003.

YOU,W.K, CHOI,W.S., KOH,Y.S, SHIN,H.C, JANG,Y, CHUNG,K.H. Functional characterization of recombinant batroxobin, a snake venom thrombin-like enzyme, expressed from Pichia pastoris. FEBS letters, v.571, p.63$73,2004$.

YUAN, S., DUAN, H., LIU, C., LIU, X., LIU, T., TAO, H., ZHANG,.Z. The role of thioredoxin and disulfide isomerase in the expression of the snake venom thrombin-like enzyme calobin in Escherichia coli BL 21 (DE3). Protein expression and purification v. 38, p. 51-60, 2004.

YUK, I.H., WILDT, S., JOLICOEUR, M., WANG, D.I. A GFP-based screen for growth-arrested, recombinant protein-producing cells. Biotechnol. Bioeng., v. 79, n. 1, p. 74-82, 2002.

ZHA, X.D, REN, B, LIU, J, XU, K.S. CDNA cloning and high-level expression of a thrombin-like enzyme from Agkistrodon acutus venom. Methods Find Exp Clin Pharmacol v.4, p. 253-257, 2003.

ZHANG Y., WISNER A., XIONG Y.L., BON C. A novel plasminogen activator from snake venom. Purification, characterization, and molecular cloning. J. Biol. Chem. v.270, p.10246-10255, 1995.

ZHANG Y, GAO R, LEE WH, ZHU SW, XIONG YL, WANG WY. Characterization of a fibrinogen-clotting enzyme from Trimeresurus stejnegeri venom, and comparative study with other venom proteases. Toxicon, v.36, n.1, p.131-142, 1998.

ZHU, Z, LIANG, Z, ZHANG,T, ZHU,Z, XU,W, TENG,M, NIU,L.Crystal structure and amidolytic activities of two glycosylated Snake Venom Serine Proteinases. The journal of Biological Chemistry, v. 280, n.11, p.10524-10529, 2005. 


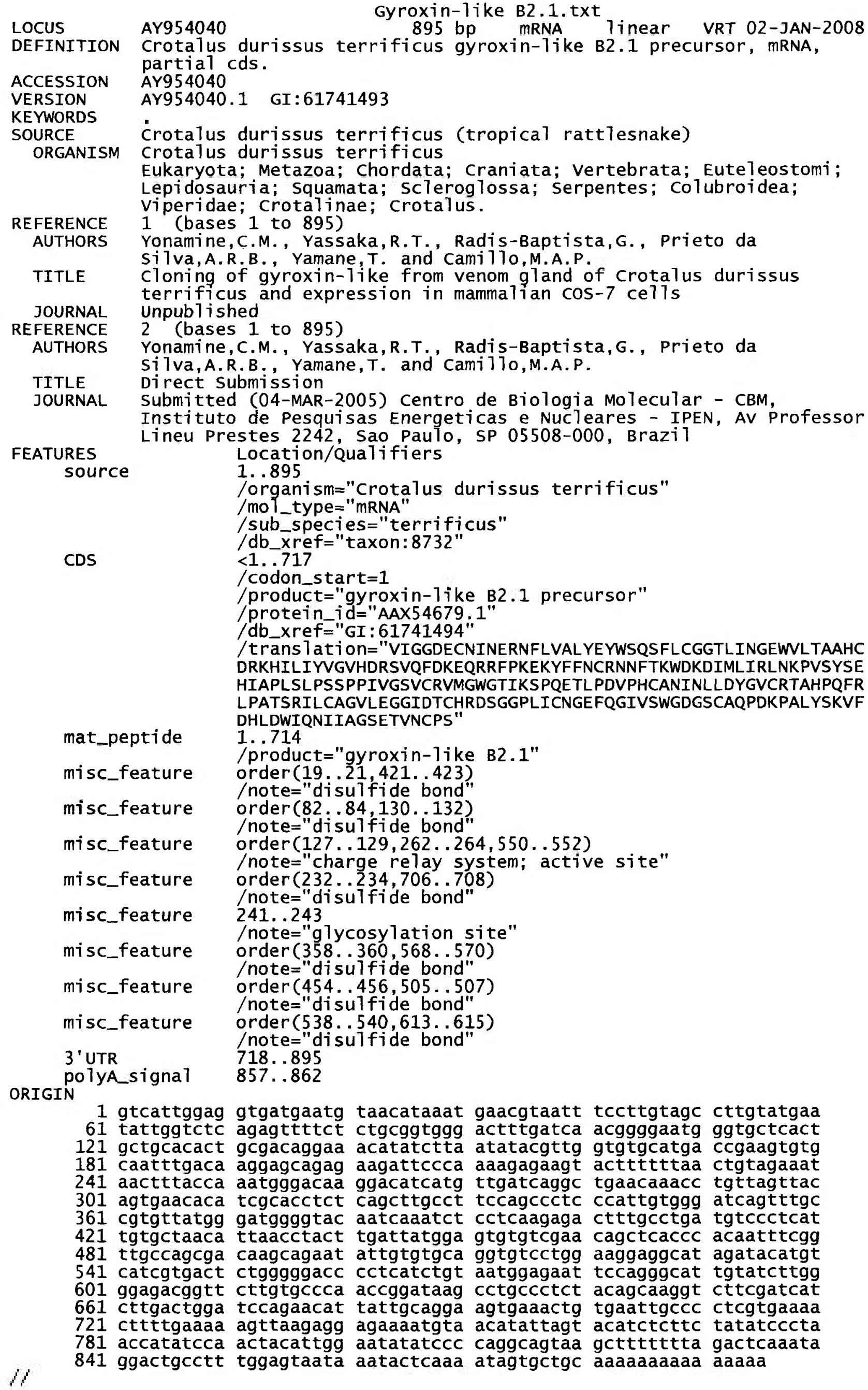

1 gtcattggag gtgatgaatg taacataaat gaacgtaatt tccttgtagc cttgtatgaa 61 tattggtctc agagttttct ctgcggtggg actttgatca acggggaatg ggtgctcact 121 gctgcacact gcgacaggaa acatatctta atatacgttg gtgtgcatga ccgaagtgtg 181 caatttgaca aggagcagag aagattccca aaagagaagt acttttttaa ctgtagaaat 241 aactttacca aatgggacaa ggacatcatg ttgatcaggc tgaacaaacc tgttagttac 301 agtgaacaca tcgcacctct cagcttgcct tccagccctc ccattgtggg atcagtttgc 361 cgtgttatgg gatggggtac aatcaaatct cctcaagaga ctttgcctga tgtccctcat 421 tgtgctaaca ttaacctact tgattatgga gtgtgtcgaa cagctcaccc acaatttcgg 481 ttgccagcga caagcagaat attgtgtgca ggtgtcctgg aaggaggcat agatacatgt 541 catcgtgact ctgggggacc cctcatctgt aatggagaat tccagggcat tgtatcttgg 601 ggagacggtt cttgtgccca accggataag cctgccctct acagcaaggt cttcgatcat 661 cttgactgga tccagaacat tattgcagga agtgaaactg tgaattgccc ctcgtgaaaa 721 cttttgaaaa agttaagagg agaaatgta acatattagt acatctcttc tatatcccta 781 accatatcca actacattgg aatatatccc caggcagtaa gctttttta gactcaata 


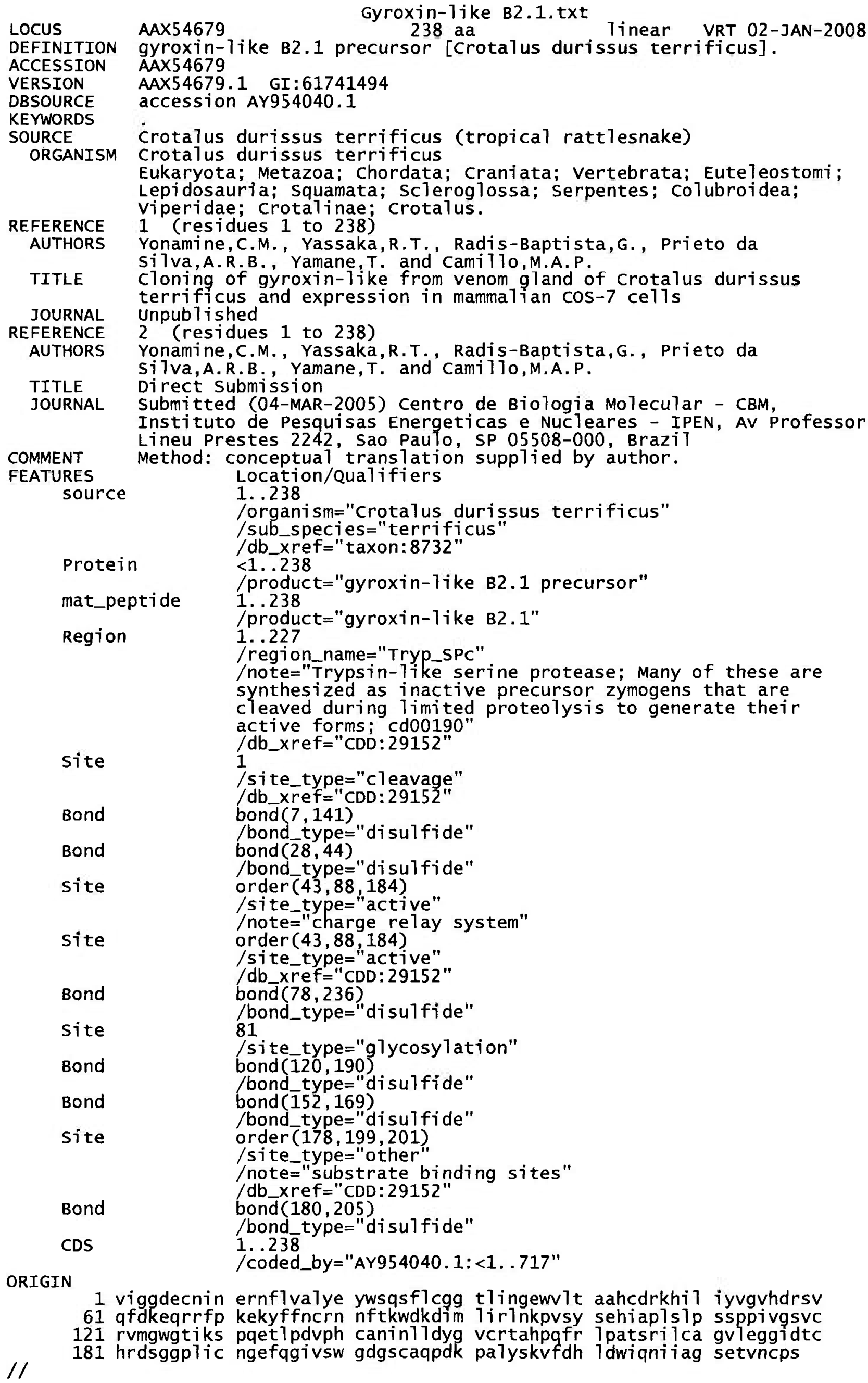

1 viggdecnin ernflvalye ywsqsflcgg tlingewv7t aahcdrkhil iyvguhdrsv 61 qfdkeqrrfp kekyffncrn nftkwdkdim lirlnkpvsy sehiapls1p ssppivgsvc 121 rvmgwgtiks pqetlpdvph canin11dyg vcrtahpqfr ipatsri lca gvieggidtc

181 hrdsggplic ngefqgivsw gdgscaqpdk palyskvfdh 1dwiqnitag setvncps

Página 1 